.F5

Copy 1

1 है है

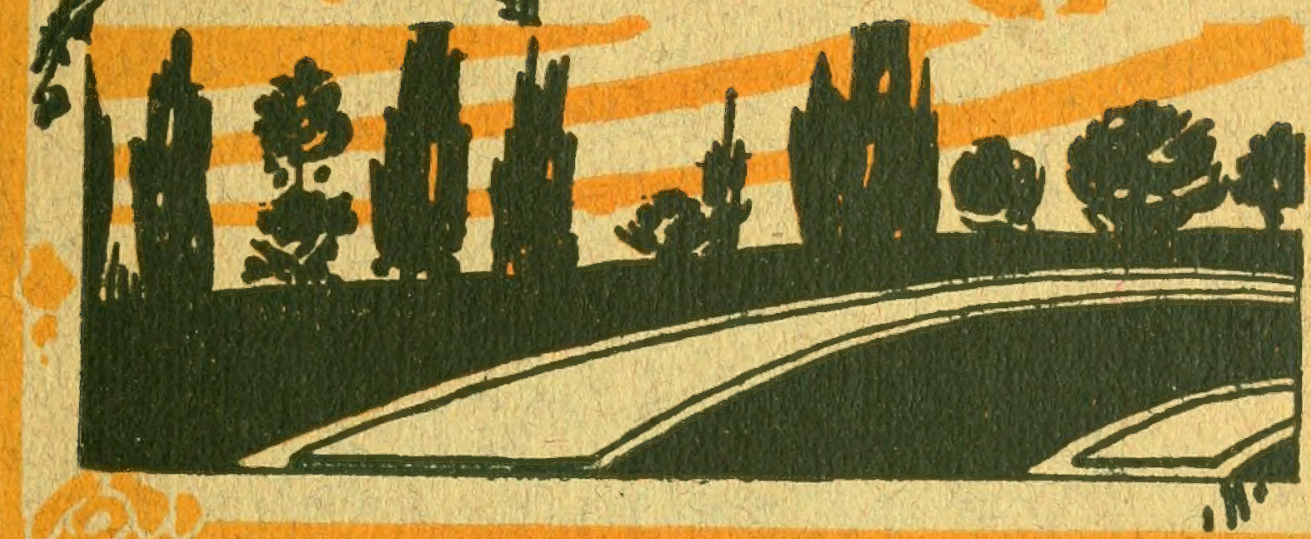
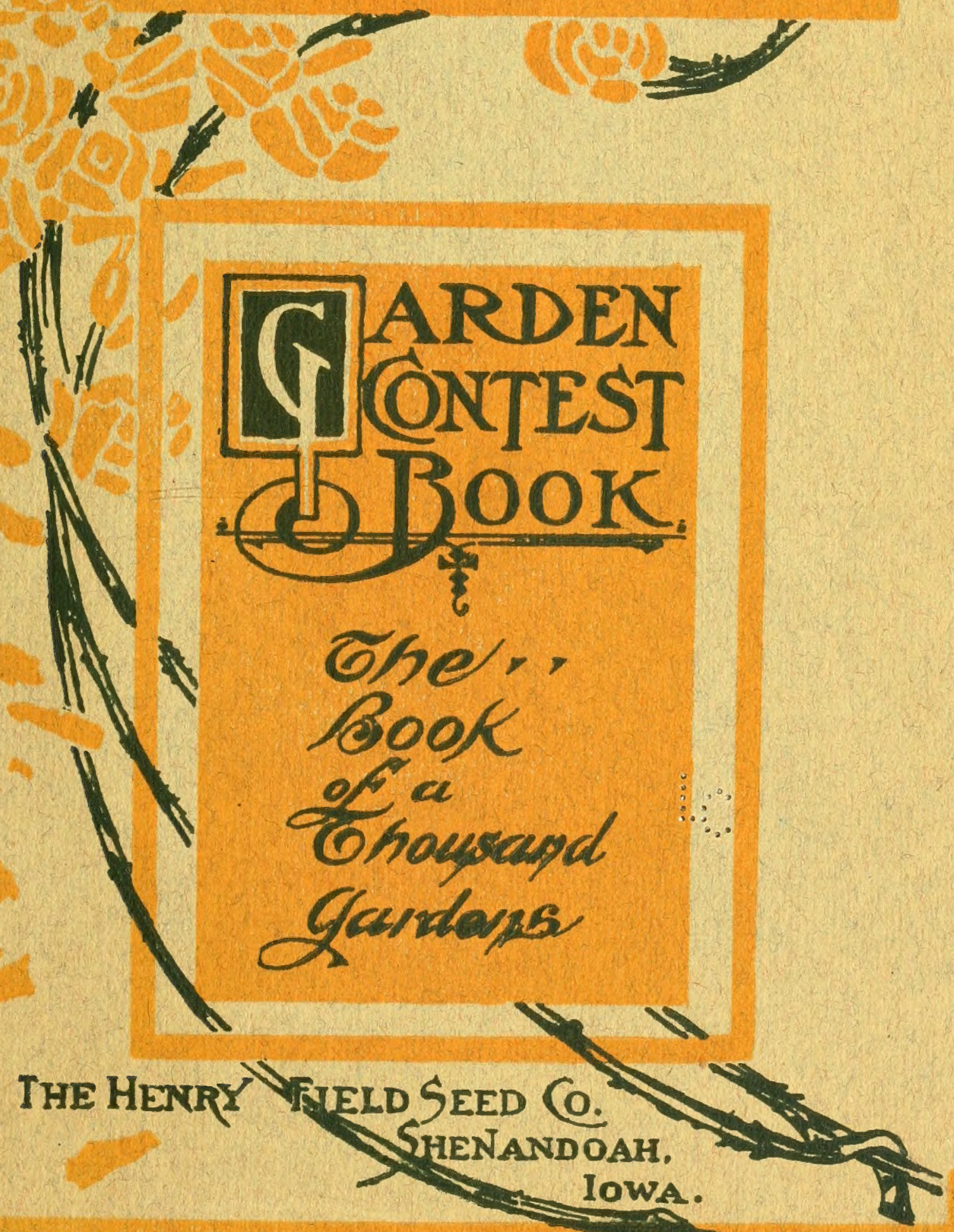
I 


\section{The BOOK of a THOUSAND GARDENS}

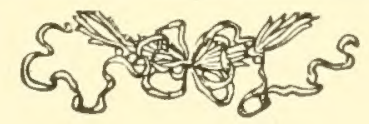

Being the True Accounts of the Trials and Tribulations and Successes in a dry year of something less than a Thousand Gardens in many States and Climates. :-: :-:

As told in a bunch of letters to Henry Field by bis loyal friends---his customers

PRICE TWENTY-FIVE CENTS

Published by

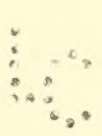

THE HENRY FIELD SEED CO. SHENANDOAH, IOWA 

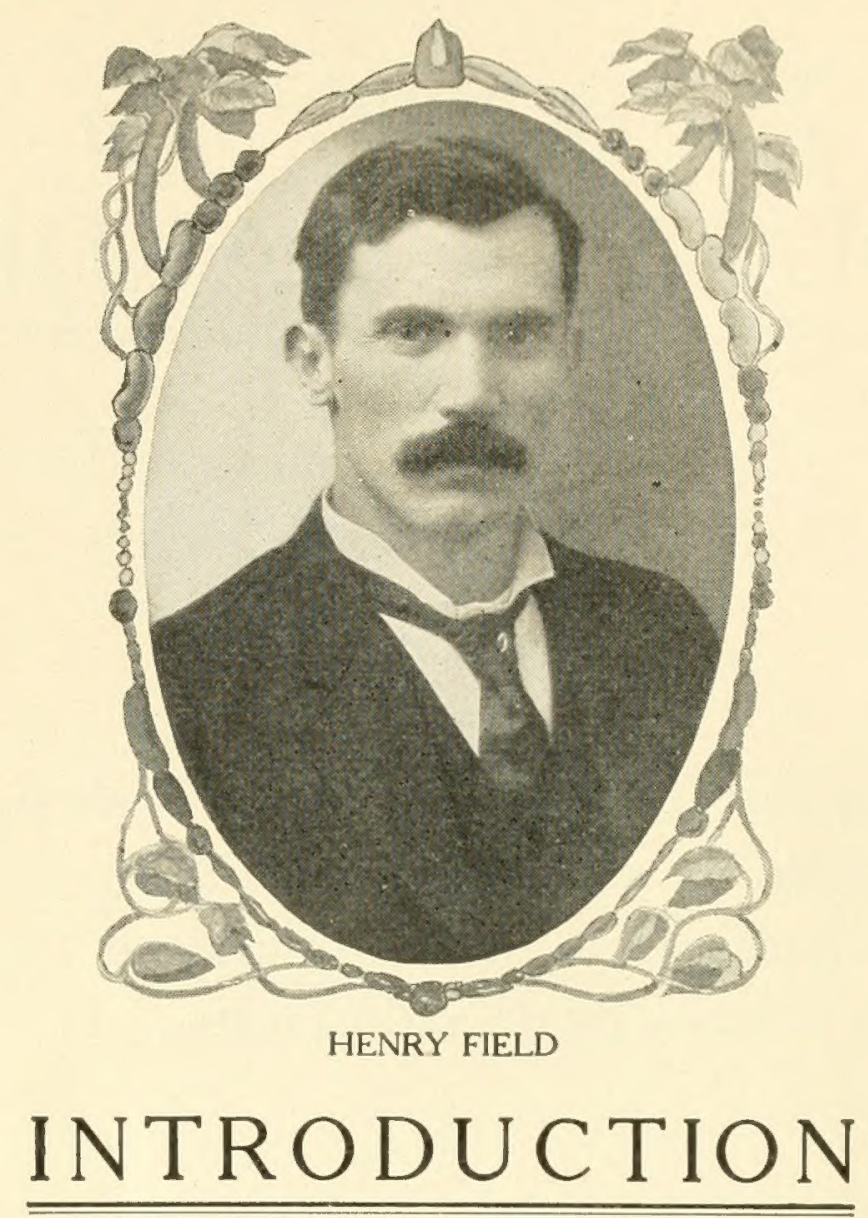

In the spring of 1911 I announced a Garden Contest, a friendly contest among my customers; to encourage good gardening. I requested them to send in the stories of their gardens, true unvarnished stories telling what they grew, how they grew it, what paid best, how big the garden was, what troubles they had, and how they overcame them. Also I asked them to send in some pictures if possible.

These letters are the result. And they are the most interesting batch of letters I ever read. They are real heart to heart talks, tcld in their own language and in their own way. And the pictures -well you can look at them for yourself.

Every garden was a real garden not a paper garden. The people were real people like you and I and our neighbors. There were men and women and boys and little girls and old bachelors. They were all'gateden cranks and garden lovers.

You can leărn more by a study of these letters than by reading all the text books in creation. You get the real stuff here. Real experience.

The only trouble was, I run short of room in the book. It would have taken a book as big as Webster's Unabridged to hold them all in full. I simply had to whittle them down to fit the book. Some few I had to leave out altogether. The rest I had to just save here and there a paragraph. I hated to throw away so much good garden talk but it couldn't be helped. But there's plenty left as it is. Read it and see for yourself.-HENRY FIELD. 


\section{THE FIRST PRIZE WINNER.}

From J. E. Butler, Lewiston, idaho.

We came to Lewiston in August, 1907, from South St. Joseph, Mo., where I had followed the house contracting business for a number of years. We first bought five acres, and then thought that was not enough, so we bought five acres more and now have ten acres, a little over 600 feet square. The house, lawn, chicken pens, corral, etc., take up about one acre, so we have about nine acres in cultivation. One acre is planted to grapes, and the balance, except two acres on the back corner, are set to trees 20 feet

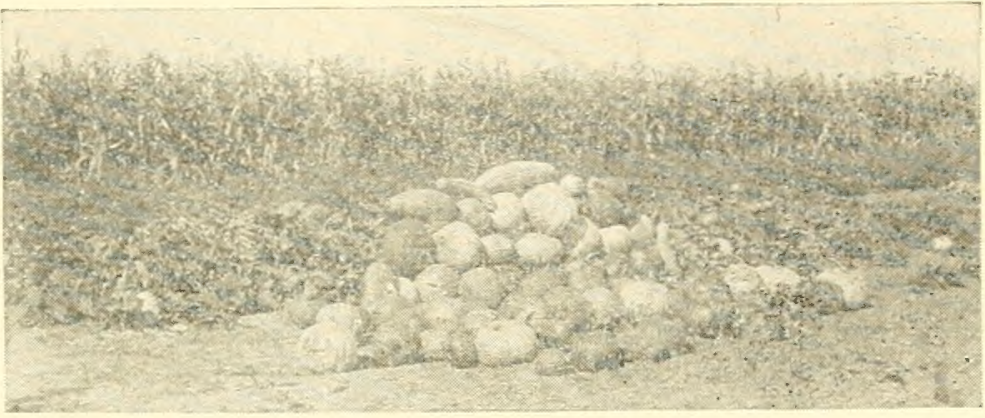

Some of Henry Field's Big Pumpkins and Squashes

apart, every other tree an apple with peach, pear, plum, etc., as fillers. When the fillers get to crowding the apples, we will take them out, which will leave the apple trees 40 feet apart. But at present we are raising our truck between the tree rows 20 feet apart, and generally have four rows in each land, except the little truck which is planted with the hand drill, we plant seven to eight rows.

Products sold from the ten acres in 1911 were as follows: SALES BY MONTHS.

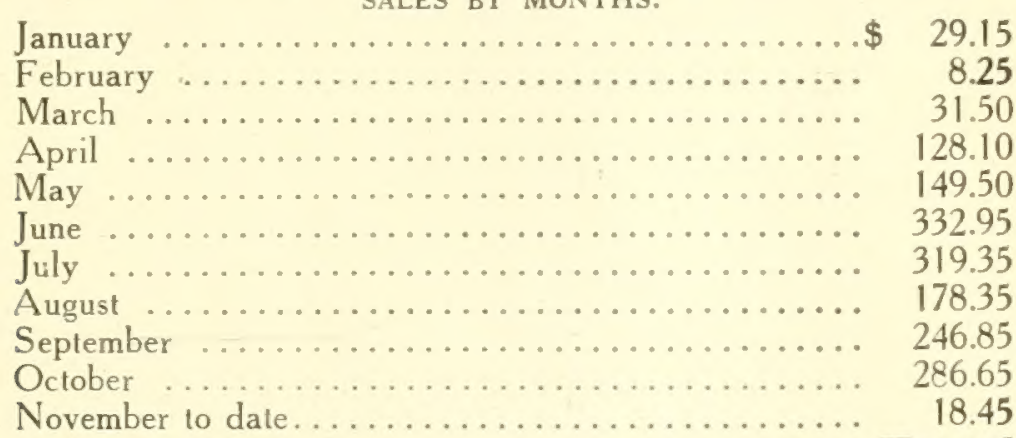

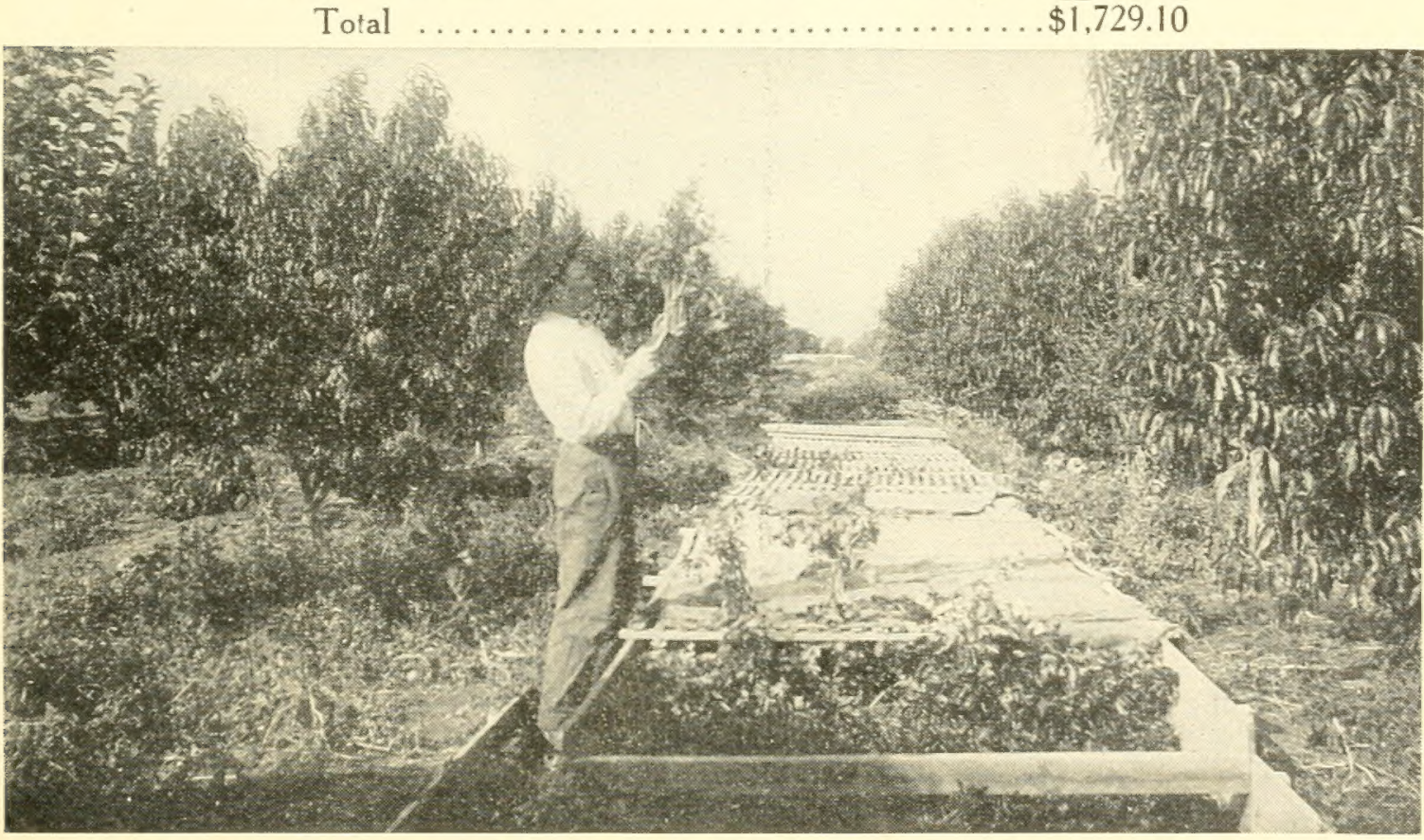

Taking out Celery 


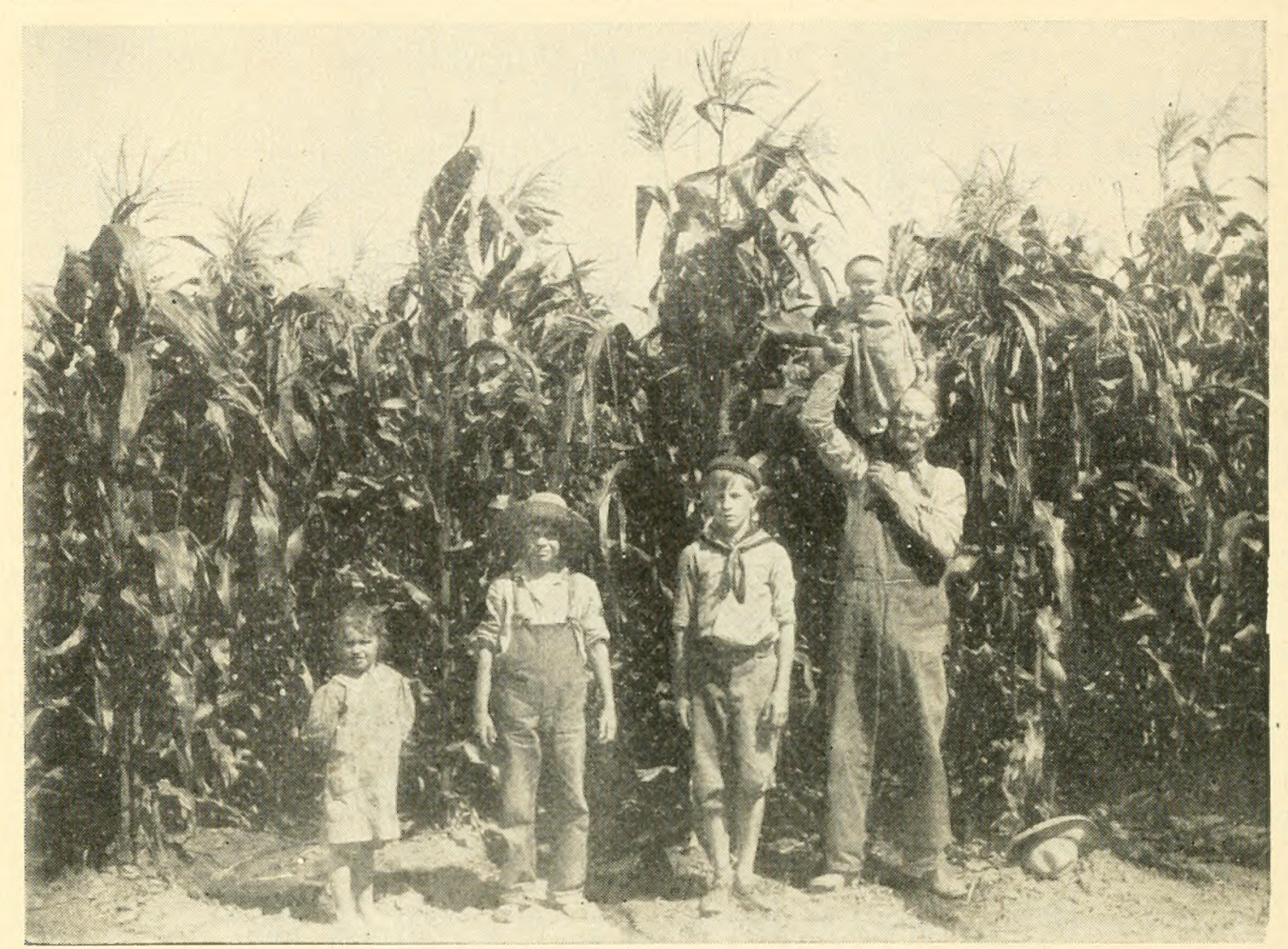

Iowa Field Corn. Some of Henry Field's Big Corn.

Largest week sales, June 12 th to 17 th.......... \$ 96.25

Largest days sales, July $3 \mathrm{~d} \ldots \ldots \ldots \ldots \ldots \ldots \ldots .26 .35$

We planted our first garden this year March 9th, and when it was gone raised a summer crop of green onions and lettuce, and expect to plant the same land again yet this fall to onions, spinach and lettuce which winter here all right.

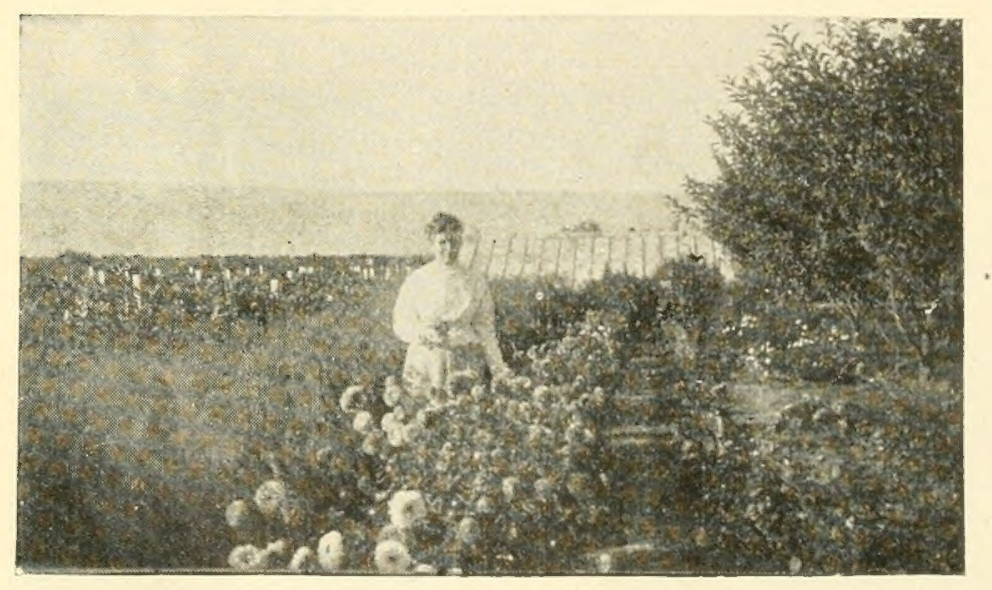

We also Raise Flowers.

Being as we are raising trees and a crop of vegetables at the same time, we do considerable fertilizing with barnyard manure. Otherwise, we would retard the growth of our trees, and we thoroughly work the manure through the soil so as to get good results right away. If I were to move back East again I would make it a point to mulch with manure as much as possible, as every rain fertilizes the ground and the mulch holds the moisture, and the crops will be nearly twice as large. We got $\$ 100.00$ from a row of Black Raspberries 600 feet long that were heavily mulched. We found it paid us big for the time it took to mulch our corn, potatoes, pumpkins, squash, etc., after we laid them by. Of course, if you had 200 or 300 acres you couldn't very well do it, but where you have only five or ten acres and are doing intensive farming and expect big results, you will have to take advantage of all these things to get those results.

The first land of cabbage we raised this year was nearly eaten up with green aphis, as we 


\section{THE BOOK OF A THOUSAND GARDENS}

had a cold, backward spring which was good weather for aphis. We sprayed, dusted and worked with them, but the aphis seemed to be getting thicker all the time and we were just about to plow them up, when we thought we would try the chickens. We took an old hen and about 20 chickens back in the field and set the coop about in the middle of the rows, which were 350 feet long, and it certainly done one's heart good to see the way they cleaned up those aphis. It seemed like those little chickens were going up and down those rows from daylight to dark looking for aphis, and it was certainly amusing to watch them.

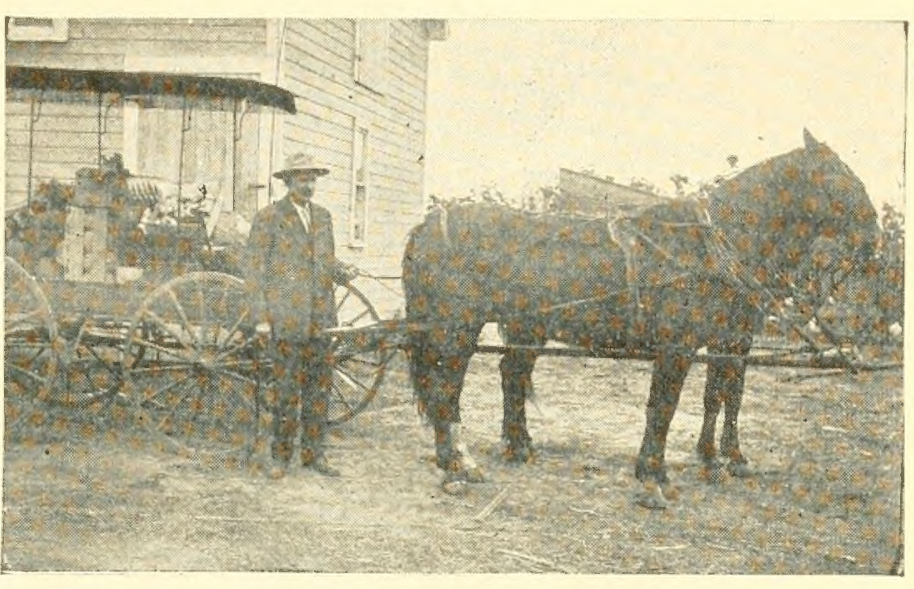

One of Our Loads for Market

Celery, we find requires a very rich soil and a lot of good cultivation. We find it rather hard to grow in this dry climate. Golden Self Blanching is our favorite.

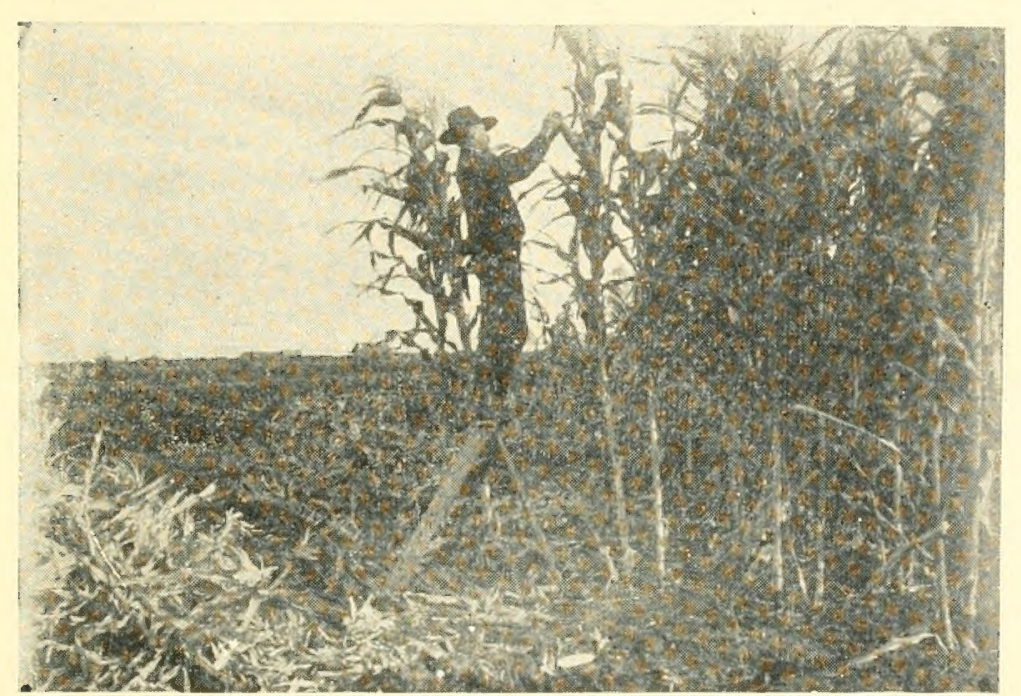

Husking some of Henry Field's Mexican Giant Corn

We think ca.n taloupes, as a usual thing, are the easiest crop grown, the easiest on the ground, and bring about the best results.

Potatoes, we plan t about four feet apart, and our best yield was 650 lbs. from a row 250 feet long, at the rate of about 480 bu: per acre. Our potatoes were inclined to grow large, but we are going to try to overcome that next year by cutting a single eye and planting real thick in the row.

We have tried Field's Early June tomato for two vears and find it a

fine tomato. The vines grow large and rank and full of tomatoes clear until frost. We picked a peck of green ones from one vine the middle of October. Tomatoes blighted badly this year, and we found they done the best in among the trees and next to the building. After it got to freezing, we gathered the green ones and put them in the house and let them ripen there. We are still eating tomatoes (Nov. 14) and expect to have them for some time yet.

In Lettuce, we find Hanson the best. We planted a lot last fall, which

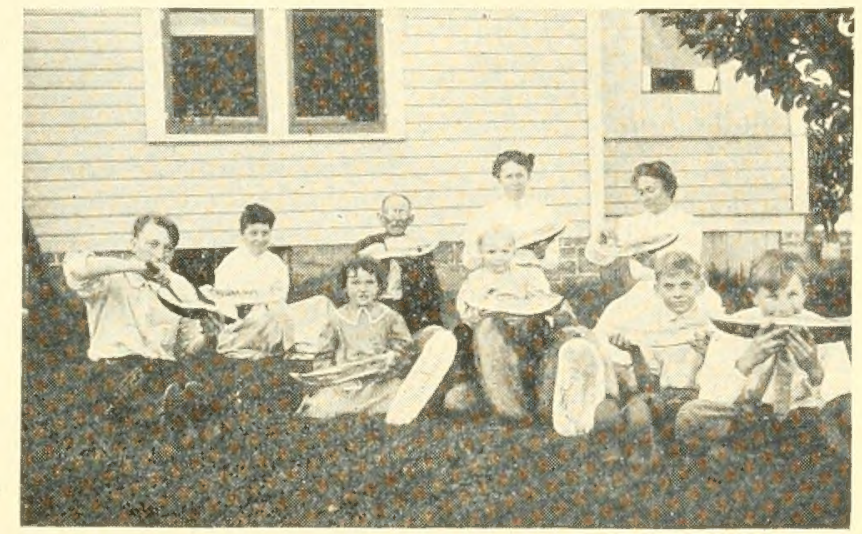

Have a slice 


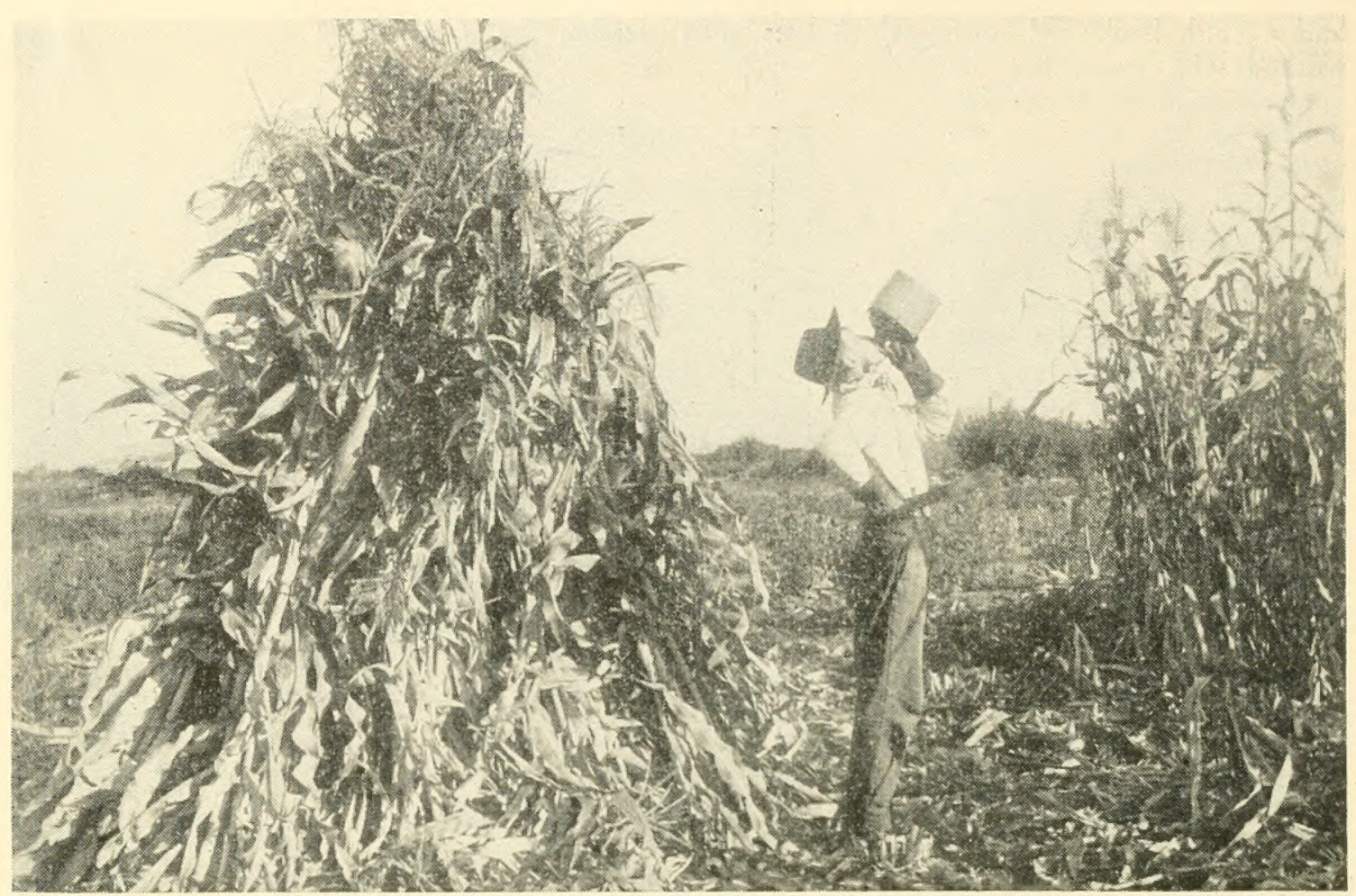

Scmething Like Work, Cutting Up Some of Henry Field's Big Corn

wintered over, and we sold it this spring at 15 cents per lb. And this spring we planted two rows 350 feet long from which we sold $\$ 24.00$ worth at 5 cents per $\mathrm{lb}$., besides feeding a few hundred pounds to the cow and chickens. Some of the heads weighed as much as $1 / 2 \mathrm{lbs}$. and were nice and white inside. We make it a rule, as fast as we get off one crop to get something else in right away and make the ground bring us some returns.

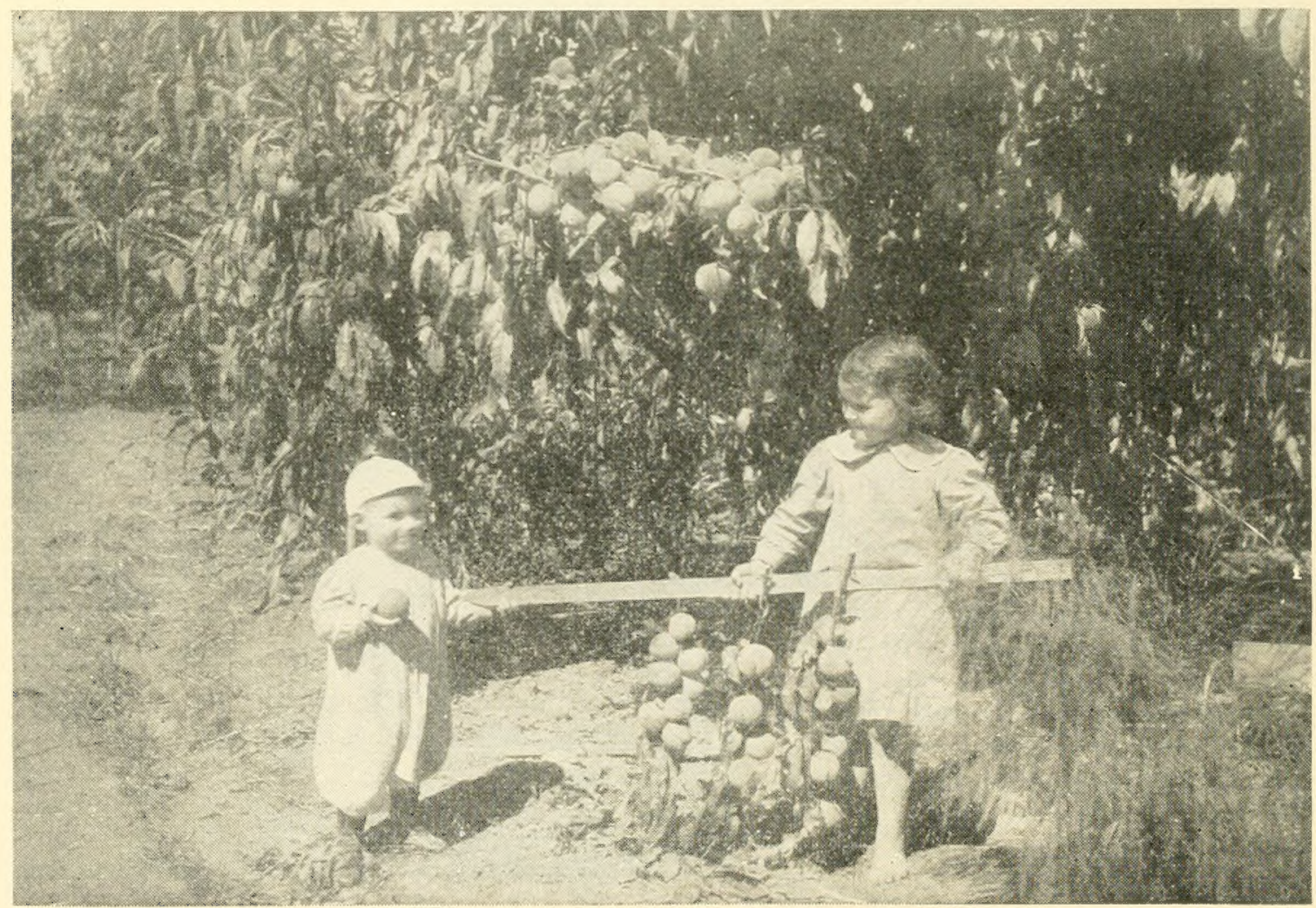

Peaches in General 
We have been buying all our seeds of Henry Field for five years, and like his seeds and manner of doing business fine. He seems more like a friend or acquaintance than a distant business man.

Just a word about expense. I worked at my trade, carpentering, before the season opened, and am working again now; and will take in more money than I paid out for help, but you may be sure we work, and work to advantage:

J. E. Butler, Lewiston, Ida.

\section{A REMARKABLE GARDEN IN DAKOTA.}

From P. R. Culver, McNeely, S. D.

I have lived in Chicago many years and this is my first attempt at gardening. I am much pleased with my success and want a much larger garden next year. Other gardeners are asking where I got my seed. One man was here yesterday who has three acres of onions, and he thinks my onions beat his.

The total amount of the proceeds of my garden, which is a little less than seven-eighths of an acre, is $\$ 237.50$. I cannot say exactly what has paid me best, for I have not kept itemized accounts of labor, etc., as I wish I had done and will do next year. I think that beets, turnips and radishes paid as well as anything. I raised as much as three crops of some of those things on the same ground.

The ground was plowed last fall, again in the spring, and harrowed four times. I put some manure on it in the winter and might have put

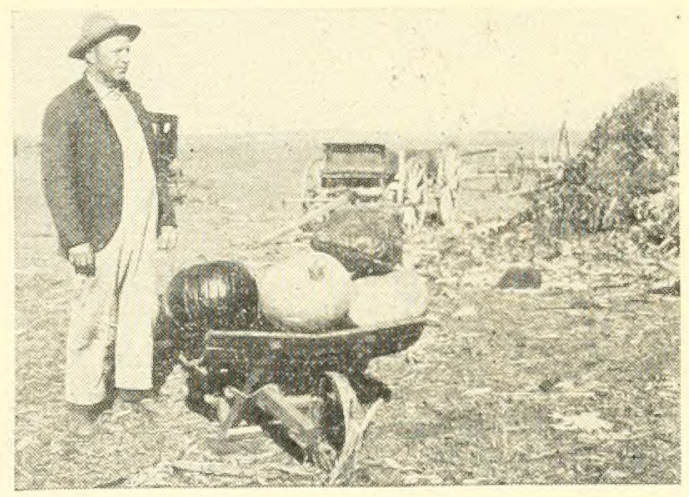

Winner of Second Prize in Garden Contest more on if I had not been afraid of the weed seed which is contained in horse manure. I kept it very clean and hoed it often. I want you to consider that this is new land

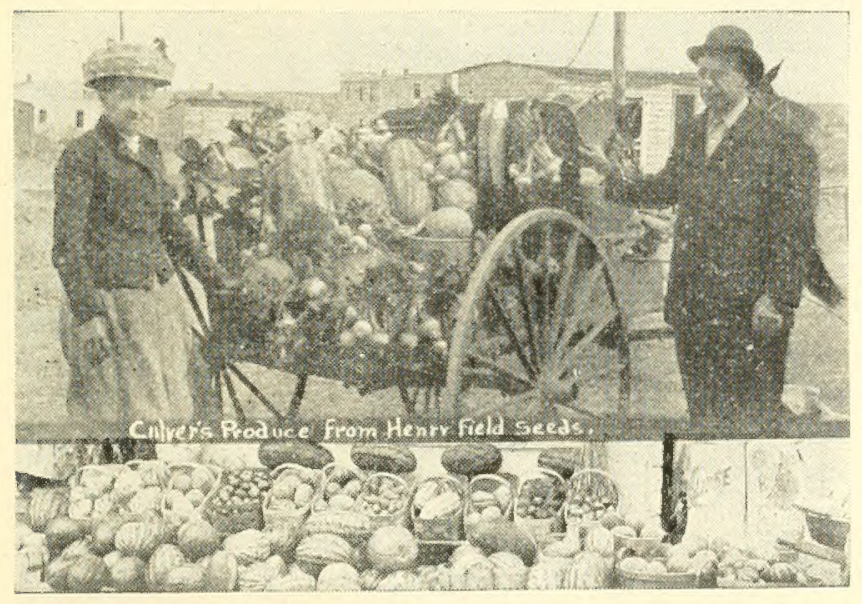

A Gool Load of Vegetables from the New Country of S Dak. P. R. Culver and Wife, IMcNeely, S. Dak. only broke two years ago and is not yet in the best condition. Also, that I am 15 miles over rough roads to market, and that the town is small, only about 500 population. I could not always sell all that I had to sell, and could not afford to go to town often more than twice a week. If I had been near a good market, I could have made much more out of my garden.

I have learned some things and think I can do much better next year. I mean to raise a much larger garden next year.

We have not had a very good season. It has been much drier than we could wish.

I placed tin cans, with a small hole in the bottom, filled with water in some of my cucumber and melon hills, but for the most part I ha e depended on the hoe. The soil is a black sandy loam, and water is not more than 20 feet down, and hoeing helps a great deal. I have no tools except a common hoe and rake. I have had to sell and eat, lettuce, radishes, onions, beets, turnips, beans, peas, squashes, cucumbers, carrots, greens and sweet corn.

Those who have seen it pronounced it the best and cleanest garden in the country.

\section{A SUCCESSFUL WOMAN GARDENER.}

From Mrs. Fannie M. Klinck, Clarksville, Iowa.

I want to tell you about my garden. My object was to have plenty of vegetables, to 
make money by winning premiums at Fairs to pay for improvements on my home, and a knowledge of the plant world. I count seed first in importance. This little quotation expresses it better than I can.

"Mother Earth may offer her choicest cradle, the sun may lavish his brightest rays, the

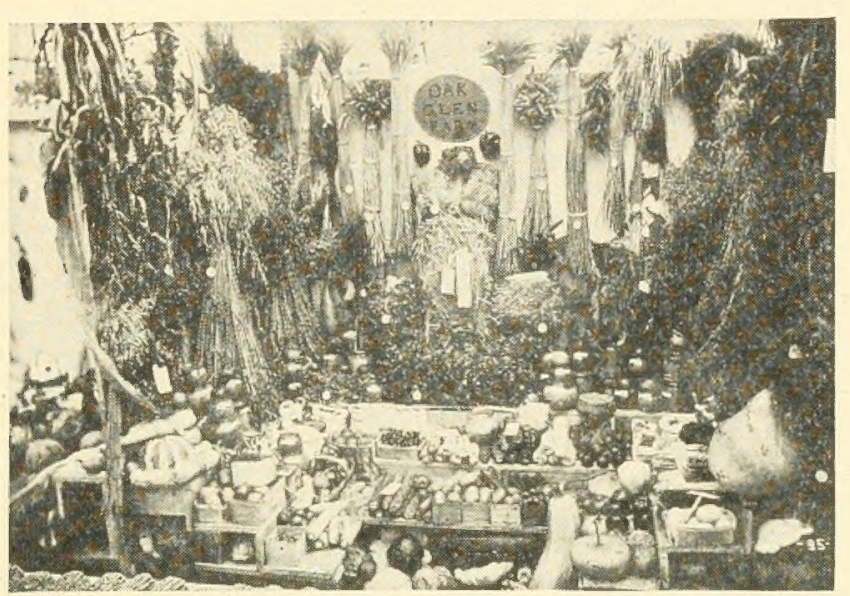

ADisplay of Farm and Garden Products at Iowa State Fair. by Mrs. Fannie M. Klinck, Clarksville, Ia., who tied with J. E. Butler for First Place in the Garden Contest. gentle showers flood down upon the balmiest wings of spring to nourish the infant plant; yet if this child of the first great cause has been touched by the blighting breath of decay, or is the off-spring of perverted parentage, all the kindly care of loving Nature aided by the hand of man, only emphasizes more strongly: "Whatsoever a man soweth, that shall he also reap."

S e c on d-Cultivation. Prepare a good seed bed, then keep hoeing and raking before the weeds start, or kill them when the roots look like tiny white threads. Keep the ground loose, don't let a crust form.

I have worked very hard and my hands are calloused and my face tanned. I have no time to do my hair up with rats, nor use talcum powder. Sometimes I felt like giving up, then I would remember that others were suffering from the drouth, too, and insect pests were everywhere. I would take the hoe or paris green can and keep working while I hoped and prayed for rain. I have been amply repaid for it all. First, in the knowledge gained, for I have tried to raise samples of as many varieties as possible and learn all about them. Have collected specimens of all the insects I could find which were injurious to our plants, also all noxious weeds and samples of their seeds. I have learned to pick out and name most of the weed seed found in grain, and of this, I am very proud and am getting more so as I find how few men can do so.

I have won in premiums this year at Fairs, $\$ 306.00$. This pays for drilling our well, a pump and windmill, and woven fence and gates for my garden and poultry yards. I have also won several articles of merchandise.

MrS. FANNIE M. KLinck,

Clarpsville, Iowa.

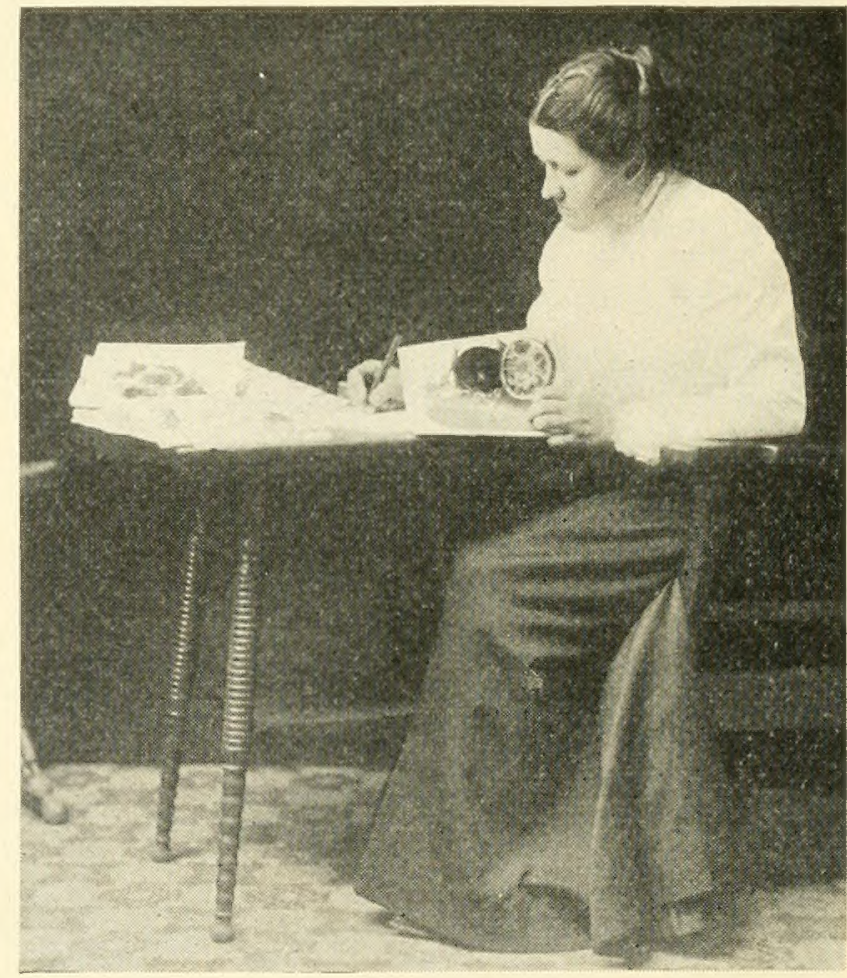

The First Preparation for the Garden-Making Out the Seed Order

\section{BUSHELS FROM 90 PLANTS.}

From Mrs. J. F. Duncan, Dederick, Missouri.

I must praise your Early June tomatoes. They are fine. My Early June plants were set out in hills after the weather turned dry. I made a hole in the hill and set the plants in and put some dry dirt on the roots, poured water in and then filled the hole up with dry dirt. Twenty out of twenty-six bore fruit. The first blossoms that came on without any rain raised fifteen bushels off of 90 plants.

Mrs. J. F. Duncan, Dederich, Missouri. 


\section{GARDEN WAS LIKE AN OASIS IN THE DESERT—SOUTHWEST NEBRASKA.}

\section{From F. S. Stevenson, Farnam, Nebraska.}

Our garden is located four miles from Farnam, in - semi-arid. southwestern Nebraska. It was just simply a farmer's garden for home use. I put the seeds in with an Iron Age drill. Just as soon as I could see the rows and somelimes before the seeds came up, I began going over the garden with the Iron Age wheel hoe, going over it after each shower, or once a week if it did not rain-which it didn't. As soon as the cucumbers and beans came up, I sprayed them with bordeaux mixture. The flea beetles were trealed to Bug Death to keep them from eating the radish tops.

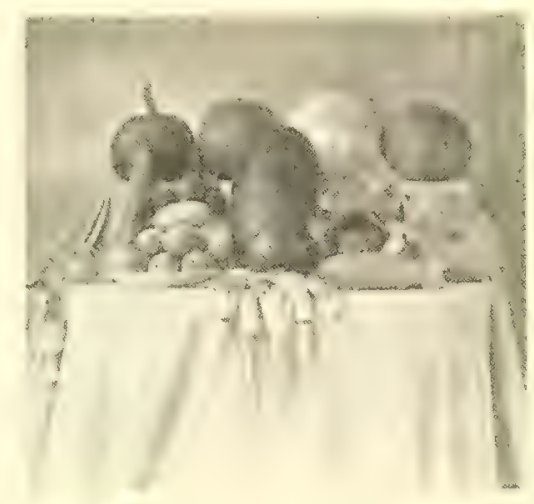

Vegetables grown in Southwestern Nebraska one of the Worst Years Ever Experienced.

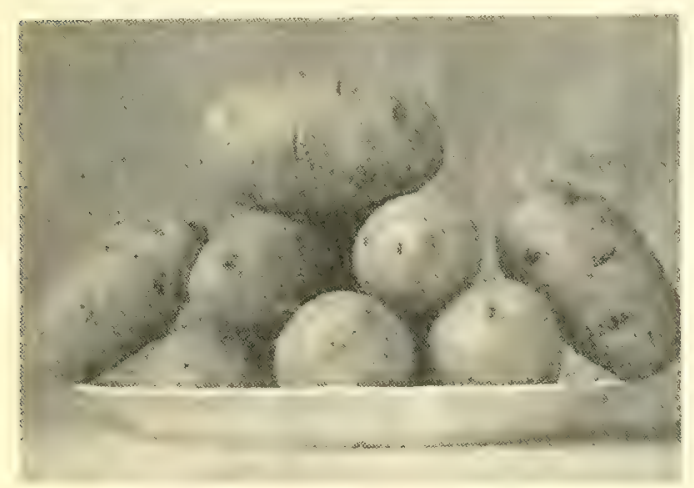

Early Ohio Potatces grown on a High. Narrow Divide Semi-Arid Southwestern Nebraska. Cultivated Shallow after every shower.

Potatoes on a Plate average 1 lb each.

a bunch, radishes seven for $5 \mathrm{c}$, beets three for $10 \mathrm{c}$, beans and peas in pods, 30c a gallon. Five rows Field's First Early beans, 60 feet long made $\$ 1.4 .30$, one row yielding one bushel at one picking and beans large enough to eat in 45 days from planting. Peas, four rows 60 feet, $\$ 6.55$. Peas to eat in forty-two days from planting. Two rows of cukes sixiy feet, $\$ 11.00$. Had slicers ready to use July 2d from seed drilled May 6th. Beets two rows $60 \mathrm{feel}, \$ 4.50$. Tomatoes 11 rows, 45 feet long, $\$ 10.00$. Ate ripe ones in 92 days from drilling of seed. Radishes, \$2.10. Had French Forcing radishes to eat three weeks from planting. Salsify four rows, 60 feet, $\$ 10.00$, lettuce, $\$ 8.50$. Cabbage, 5 rows, 60 feet, $\$ 5.00$. Field's First Early beans stands at the head as the most paying crop, rate per acre, $\$ 1,470.00$. Cukes, next, and beets a close second. If one had a market for Simpson lettuce, it would lead, as it can be planted between tomato rows and takes up no space.

F. S. Stevenson, Farnam, Nebraska.
With all our other troubles, the dry weather came. Tender bean leaves cooked crisp. Of the peas, Fillbasket came out in the lead, having stood the drouth the best of all. The others, while the best of chewing, neither came up well nor withstood the drouth. On the pea ground, we first harvested radishes, then peas. fifter the peas were picked we planted one row of cucumbers with two rows of turnips on each side.

Although my garden was but a remnant of what it should have been, it was like an oasis in a desert compared to the others. The prices were, cukes two for $5 c$, lettuce $5 c$

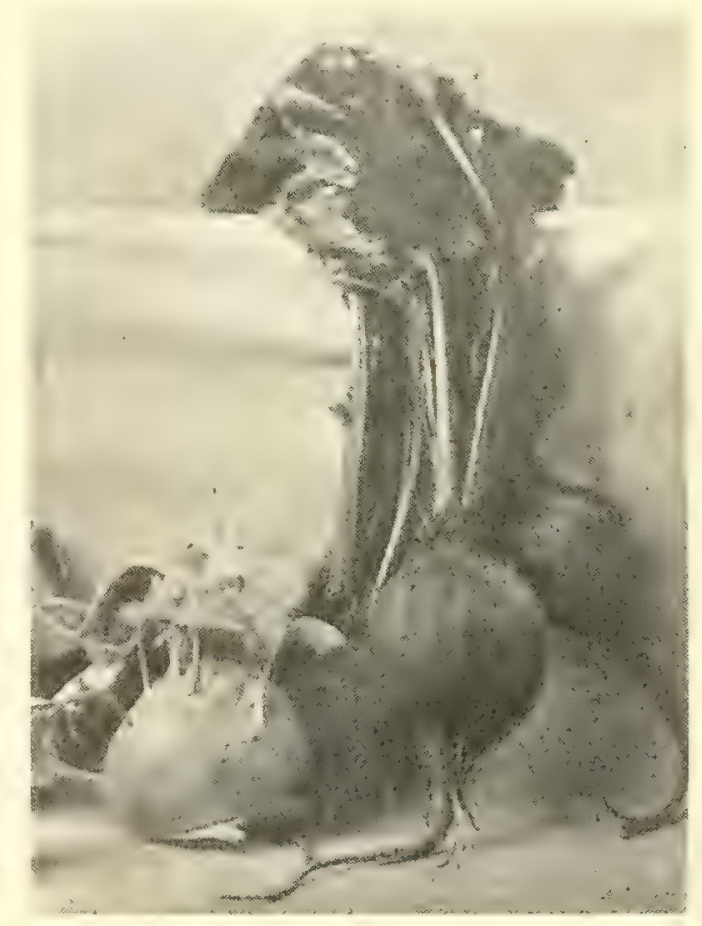

Eclipse Beets and Farly White Vienna Koh] Rabi f rown from Seeds $P$ anted Aug. 1st. 


\section{NOT A LARGE GARDEN BUT A MIGHTY GOOD ONE.}

From Mrs. M. L. Hunt, Кокomo, Indiana, 1115 N. Morrison Street.

I am sixty-four, my son busy ten hours (sometimes longer) every day, no money to spare for hired work, yet I was ambitious for a garden. So I selected and spaded most thoroughly a spot about $4 \times 20$ feet. A friend gave me some strawberry plants, enough for almost half the ground. Then May 12th I received one dozen Senators and three Early June tomato plants from you. These last, I had a place across the center of the plow, the strawberries at the other end. The full length of one side in Henderson's Bush Lima. On the other side, four hills of Princess Watermelon. For lack of space, the tomatoes were framed up pretty high. hoeing.

The season was hot and dry, but I had heard of dry farming, and kept hoeing and

Well, we enjoyed about a dozen delicious sweet little watermelons. They grew from six to nine inches in diameter. The vines were remarked about for their beauty. The tomatoes, we had from July 22nd until frost Oct. 23rd. We planted also a few Earliest in the World, but those three plants were our standby. We canned off of them and ate them every day.

I also rounded one end of my plot and filled it with your poppies, forgot the name. I should have written in August when I could sit on the steps of the back porch and see these. The garden was little, but I can't tell all the good it did us. My strawberry plants spread over almost the whole plot, so I hope the best is yet to come.

Mrs. M. L. Hunt, 1115 N. Morrison St., Kolomo, Indiana.

\section{PLENTY TO EAT FROM A THIRD ACRE.}

\section{From Mrs. Jesse Crook, Nebraska City, Nebraska.}

There is about one-third of an acre in my garden plot. I planted all I could with a drill, and when about three inches high, I scattered manure from the hen house over all of it. When the first planting of radishes, spinach and lettuce were too old to use, I hoed them out and replaced them with late beans.

I have not sold anything from my garden yet, but will have a few parsnips, carrots and turnips to sell. I have canned two hundred and fifty quarts of tomatoes and one hundred and twenty-two quarts of beans from my garden. I have a bushel of popcorn, also, a gallon of cucumbers. I supplied some of my neighbors with vegetables from my garden. I have the very best in our neighborhood. And we used seed from Henry Field Seed Company.

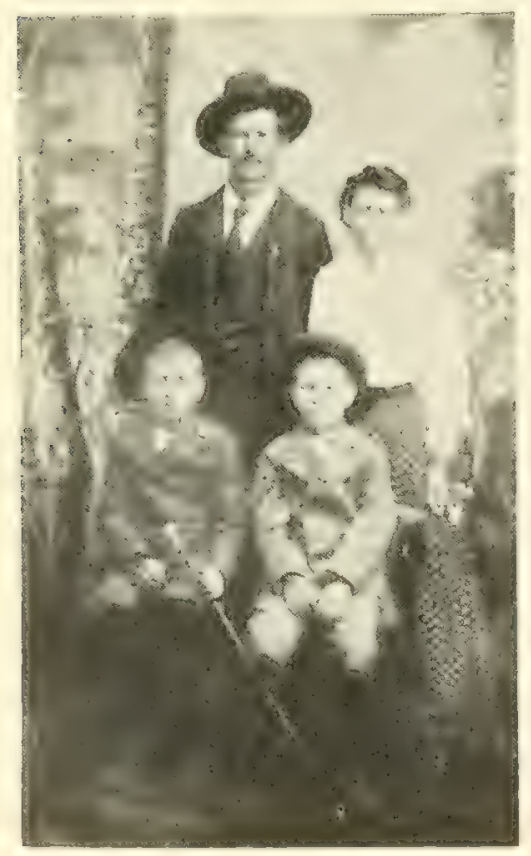

Mrs. Jesse Crook, Nebraska Cily, Nebraska.

\section{BEST GARDEN IN SHELBY COUNTY.}

From Mr. James A. Swango,

ShelbyVille, Indiana.

I have got one of the finest gardens in Sheiby County, if the dry weather was against me a little. I am sending you my picture and of my wife and two boys. They are all garden cranks.

Everybody that goes along the road wants to know where I got my seeds and what made my garden grow so nice. I told them I got it from Henry Field Seed Company. I have about fifteen or twenty who wants me to send up there next spring for their seed. By that, you may know I have a fine garden.

Mr. James A. Swango, Shelbyville, Indiana.

James B. Swango and his Garden Helpers 


\section{A BIG SUCCESS IN THE SAND HILL COUNTRY OF NEBRASKA.}

From Mrs. James Hall, St. Paul, Nebraska.

This is the part of the country formerly known as the Great American Desert, now by the name of the sand hills of Nebraska. Our place is sixteen miles north of Grand Island.

We planted about an acre to early vegelables. It gave great promise of an excellent yield, but about the 22d of April we had a severe sand storm lasting about four days, and on the 18 th of May a genuine blizzard finished our early prospect. We at once replanted and set and reset both cabbage and tomato plants, as it was very dry and unfavorable. Some places we set five times.

On August 22d, we telephoned to a dealer in Grand Island what he was paying for large cucumbers and sweet corn. $\mathrm{He}$ said he had not bought any for a year but to be sure and see him first. I sent thirteen dozen slicers and forty

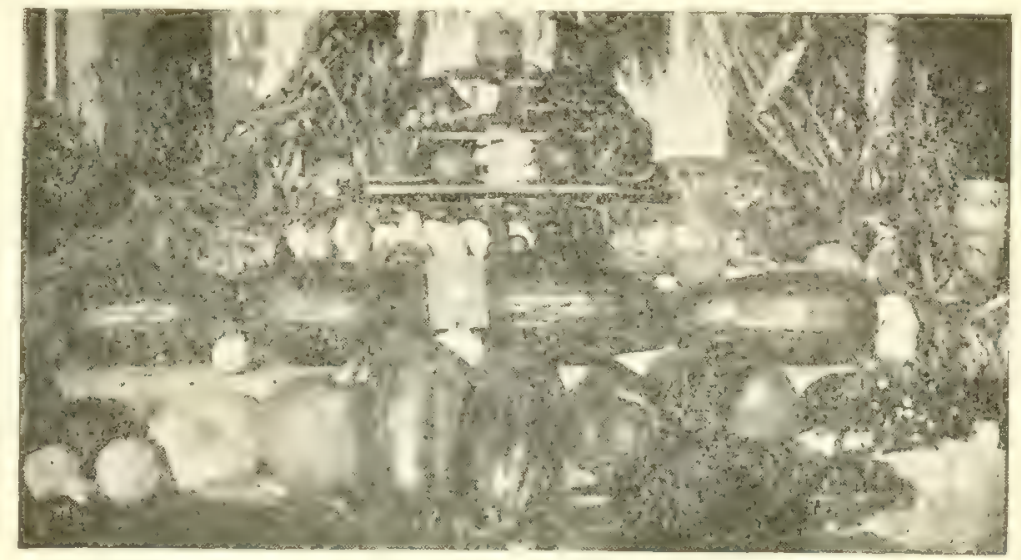

A Wonderful Collection of Vegetables grown in the "Sand Hill Countro" of Northern Nebraska in the Dry Year. That's certainly going some.

dozen ears of corn and nine dozen muskmelons. Cucumbers brought $50 \mathrm{c}$ per dozen, corn $15 \mathrm{c}$, and melons $80 \mathrm{c}$ and $\$ 1.00$ per dozen. That was our first load. The dealer offered to send after the produce if we would sell exclusively to him. The next load was fifty dozen slicers, 80 dozen corn and 1,700 pickles and 16 dozen melons. The distance is so great we don't go every day but go every other day. If we had been as wise as we are now, we could have sold some of your Princess watermelons, as they were ripe at this time, but we did not look for them to ripen so early and came near losing them by the oversight.

We cut pickles until two weeks ago and could not supply the orders. We have the greatest yield of tomatoes. We pick about four or five bushel at a picking. Our late cabbage we set out on July 13 th and some of the heads at the present time will weigh six or seven pounds. We thought it was too late to set very many. I sold several hundred cabbage plants and about 4,000 tomato plants.

1. Mrs. James Hall, St. Paul, Nebraska.

\section{FIVE BUSHELS FROM THIRTY PLANTS.}

From Elijah E. Brown, Shannon City, Iowa.

I planted the seeds in a little box the 27 th of March, and they grew fine, and the sixth of May I set them out, and they grew beiter than the other planis that were set out before. There were 30 plants and off the thirty plants they yielded five bushel of tomatoes. The onions grew strong and healthy, but the drouth killed them so I lost them.

I planted Halbert Honey melons the tenth of May and they grew fine. I planted from six to eight seeds in a hill, and after the bugs had stopped working on the vines, I pulled them out to three to four in a hill. They yielded about 1,500 lbs. of melons.

Elijah E. Brown, Shannon City, Iowa.

\section{FINE OLD FASHIONED FLOWERS TOO.}

\section{From S. A. Richardson, Winchill, Texas.}

This year, I had some of the finest flowers I ever saw, according to the chance they had. My zinnia seed I ordered from you produced the finest blooms and stalks I ever saw. I had one zinnia that measured three feet across each way, was three feet four inches high, and had 186 blooms on it that measured two inches across. I just simply thought it was the prettiest flower I ever saw. I would have loved to have had a picture of it for you, but it was im. possible for me to get it. 


\section{SOWS EVERYTHING IN STRAIGHT ROWS.}

Chas. A. Meier, Miama Sta., Missouri.

Although I am now sixty-four, I still enjoy to work and make a good garden, and what I learned to love in my boyhood days in the way of making garden is still a joy to me.

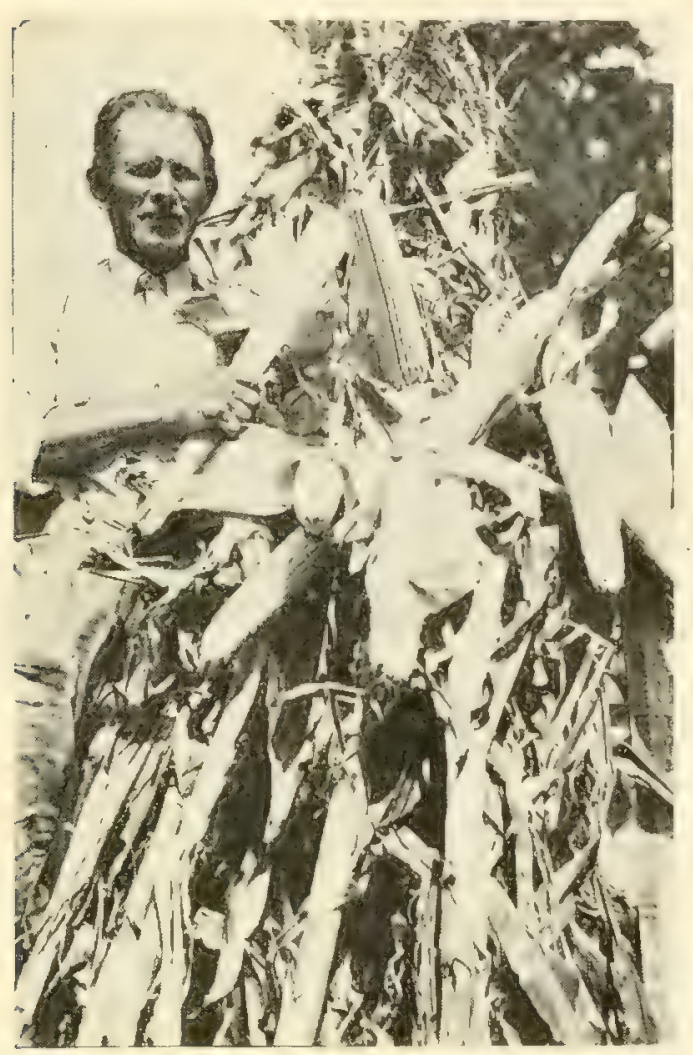

For a family garden plenty big enough to have room for most everything good to eat, I would suggest two hundred feet long by one hundred feet wide, and as close to the house as convenient. The next thing needful for a good garden is a good fence around it. I split my own paling out of timber.

I sow all my seed in straight rows. I make just a slight ridge with a garden plow, then I stretch a line and sow my seed. I make my rows about a foot apart for lettuce, radishes, spinach, onions and all those smaller seeds. Peas, corn, butter beans, and all those bigger seeds, I plant from two to three feet apart. Although we had a severe drought this summer, our garden was the admiration of the neighborhood. Some of my neighbors said, "How did you get your rows so straight." I told them with a line. Others said, "What do you do with all that garden." I tell them $I$ find good sale for butter beans and tomatoes and onions at all times. Strawberries always sell well. We have only a garden for family use, but we sell enough out of it to more than pay our outlay for seeds.

Chas. A. Meier, Miami Sta, Missouri.

Boone Co. White Corn. 12 Ears weighed 16 1-2 Ibs.

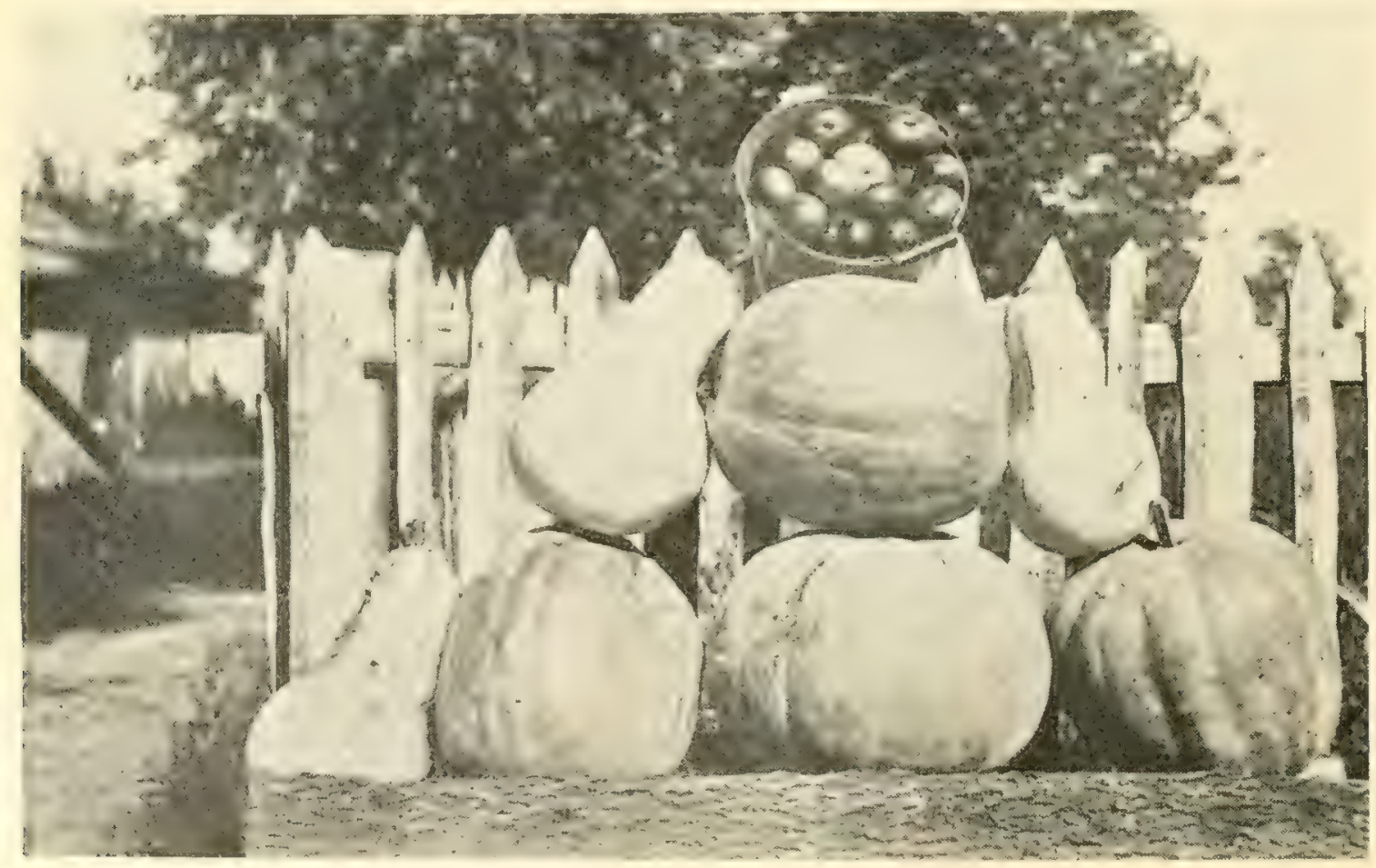

Pumpkins, Squashes, and Tomatoes from a Missourl Garden 


\section{A CONNECTICUT BOY HAS A GOOD GARDEN.}

\section{From Otto Baur, 14 Davis St., Danbury, Connecticut.}

The first thing I done to have a fine garden this year was to spade the ground thoroughly in the fall of 1910. Early in spring after I received what seeds I needed for the season from you, I made a plan, showing the space allowed for each vegelable, location of the different varieties, etc. My garden is divided in two sections. The size is $20 \times 45$ feet.

I had only a small space to grow vegelables for market this year. My beets paid me better than carrots and onions. To keep my garden in good condition, I had to get up at 3:30 o'clock in the morning. I work in a grocery store from 7:00 a. m. until 6:30 p. m. That left me about one hour to enjoy myself with a hoe

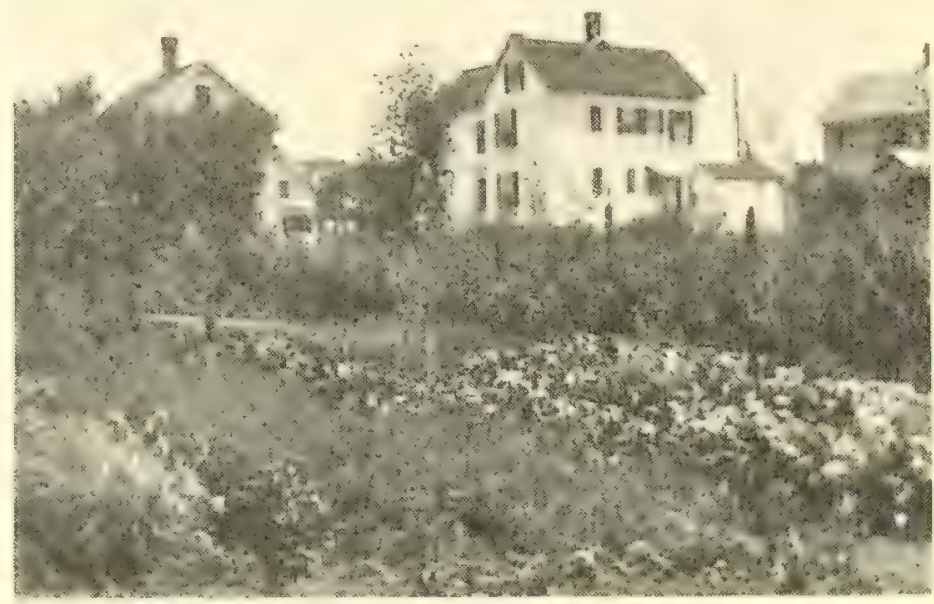

A Good Garden in Connecticut, from lowa seeds each day after coming home from work. I first became interested in gardening when I was fourteen years old. I am now seventeen. $\$ 9.75$.

My entries this year at the Danbury Fair numbered forty-one. I received for premiums,

Otто Baur, 14 Davis St., Danbury, Connecticut.

\section{IT PAYS BIG TO HAVE A GARDEN AND ORCHARD.}

From Mrs. Ella Lehr, Winston, Missouri.

My garden is 83-99 feet. I have four cherry trees from which I canned 12 quarts and sold $\$ 5.25$. Then five grape vines east of them, I canned five quarts and used all we could. Then I have a bed all around my garden, which is used for my pole beans and butter beans to run on the fence.

The rest of my garden is one large bed with rows made straight by stretching a string across. I planted five rows of onions, mostly seed, two rows of radishes, one of lettuce, parsnips and salsify. One of beets, iwo of peas, one of celery and cucumbers, and the rest in cabbage and tomatoes. The celery and cucumbers were killed by the drouth, but the other things did fine. I had the first radishes, onions, and lettuce the fifth of May, and the first peas and beets the 28th of May.

I sold $45 \mathrm{c}$ worth of cabbage, made 18 gallons of kraut, gave away 50 heads and have 100 heads yet in the garden. Tomatoes, I canned 50 quarts, sold $\$ 14.27$ worth, gave away 4 bushel and have lots in my garden yet. Butter beans, I used all I could, shelled for winter about $25 \mathrm{c}$ worth, and have lots of them green yet in my garden.

I used mostly Henry Field's good seeds, plant them as early as possible and tend them good. I don't know how to tell how much I raised, only I have a family of six, four boys from five years up to 21 years, so I have a good home market for garden.

This is the exact truth about my garden. I had no time to take pictures. Excuse my not writing with ink.

Mrs. Ella Lehr, Winston, Missouri.

\section{LOTS OF FINE TOMATOES.}

From Geo. Klein, Kansas City, Missouri, 3136 Cleveland Ave.

The garden was not a good success because of the drouth, but I raised lots of your fine tomatoes and sold $\$ 60.00$ worth, and we still have tomatoes on the vines. We raised nice string beans and sold $\$ 30.00$ worth, and the peas were all right, too. We sold $\$ 125.00$ worth altogether, and would have sold more but we didn't have any rain. 


\section{THE BOOK OF A THOUSAND GARDENS}

Sorry I can'l send some pictures, because I know it will make you feel bad. My garden paid me well. I kept the weeds out and cultivated it, too. This is all true, Mr. Field.

Geo. Klein, Kansas City, Missouri, 3136 Cleveland Ave.

\section{PLANTED POTATOES IN A SNOWSTORM.}

From Mrs. Lena Tossell, Crivitz, Wisconsin.

I raised last year on one-half acre of ground twenty bushels of onions, and I sold thirteen bushels at $\$ 1.00$ per bushel. My early potatoes, I sold at forty cents a peck. I planted

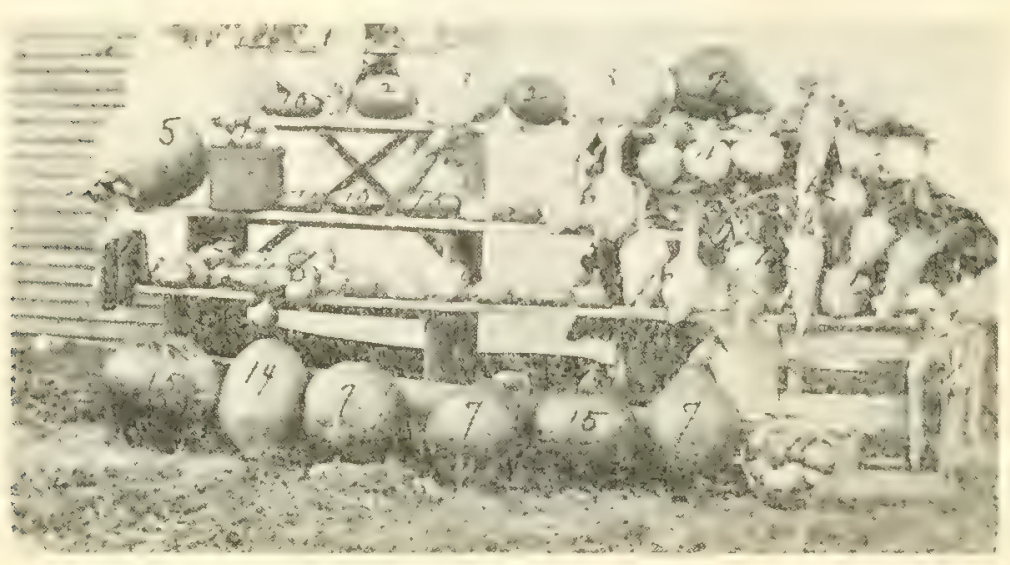

16 Kinds of Vegetables grown in a Garden in the "Cut Over" "Country of Northern Wisconsin. them the 23d of April in a snowstorm. People laughed at me, but I was the one to laugh last. It was so dry last year that I saved all my wash water and carried barrels of it and it paid me, for I had a fine garden.

I had three different plantings of sweet corn, and sold the most of it for one cent an ear. I had three wagonloads of squash which I sold at ten and twenty cents cach. I had one squash that weighed over thirty-

five pounds. I never saw such radishes, they were so tender.

My husband plows real deep and harrows the garden two or three times, then he leaves it all to me and I plant a little of everything. I have a garden plow and seeder, so I keep it thoroughly cultivated and hoed and keep all the weeds down. That is the secret of a good garden in my eyes. I love to work in my garden.

I am a poor scholar, but it is the truth. I have told you as plain as I know how.

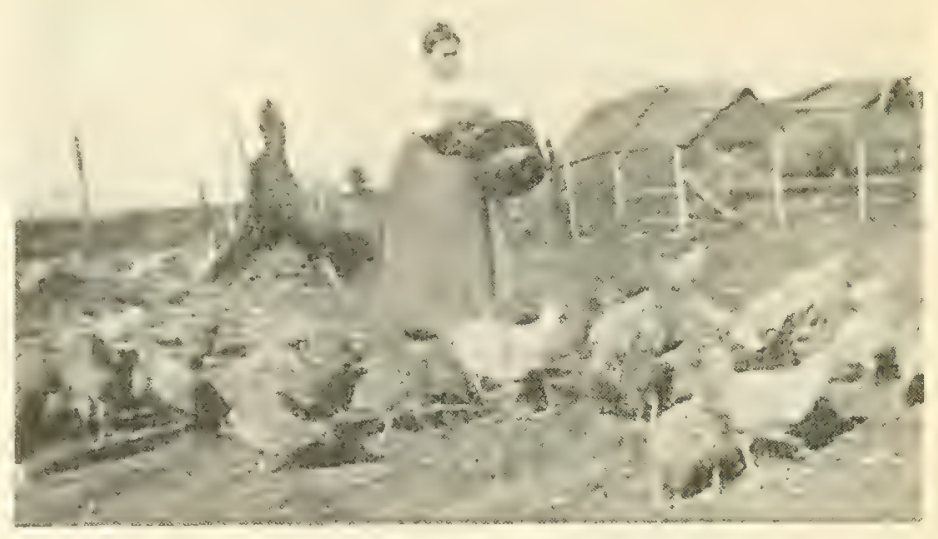

An Enthusiastic Woman Gardener and Her Chickens.

Mrs. Lena Tossell, Crivilz, $W$ isconsin.

\section{CATTLE ATE THE ONIONS.}

From Mrs. F. E. Wright, Wilsey, Kansas.

I sent for $\$ 2.50$ worth of seeds and sold $\$ 3.00$ worth of tomato plants, and $\$ 2.00$ worth of cabbage plants. My beets were good. The cattle got in my garden and ate all my onions and nearly all my cucumber vines, but I planted again and had grand success. Put up 30 gallons of pickles for myself, sold 3 bushel gren ones. I also sold $\$ 15.00$ worth of ripe tomatoes and $\$ 2.00$ worth of green ones, and I canned ten quarts of beets.

I may do better next time, as this is my first attempt.

Mrs. F. E. Wright, Wilsey, Kansas. 


\section{A SUCCESS IN SPITE OF UNFAVORABLE WEATHER.}

From Mrs. D. B. Collins, Grandview, Arkansas.

We had a small garden patch, but before I could get it plowed, I took sick. Husband planted the garden, three rows of onions, four of cabbage, four of tomatoes, two of beans, and one of radishes. It was so late that everything was planted in the hill. Well the dry weather struck us and everything died except onions, beans and radishes. So about the first of June, we planted again ten rows of beans, twelve of corn and five of sweet potatoes, with beans in every hill of corn. Just as the beans were ready to gather, a rainy spell caught them and several were spoiled. But I gathered over a half a bushel dried beans, canned twelve quarts, and pickled two gallons, besides having lots of beans to eat. Dug six bushels of potatoes; the corn was fine also, but I haven't any idea how much there is of it.

So you see it was a very good ending if a bad beginning.

Mrs. D. B. Collins, Grandvien, Arkansas.

\section{SEVENTEEN HUBBARD SQUASHES ON ONE HILL.}

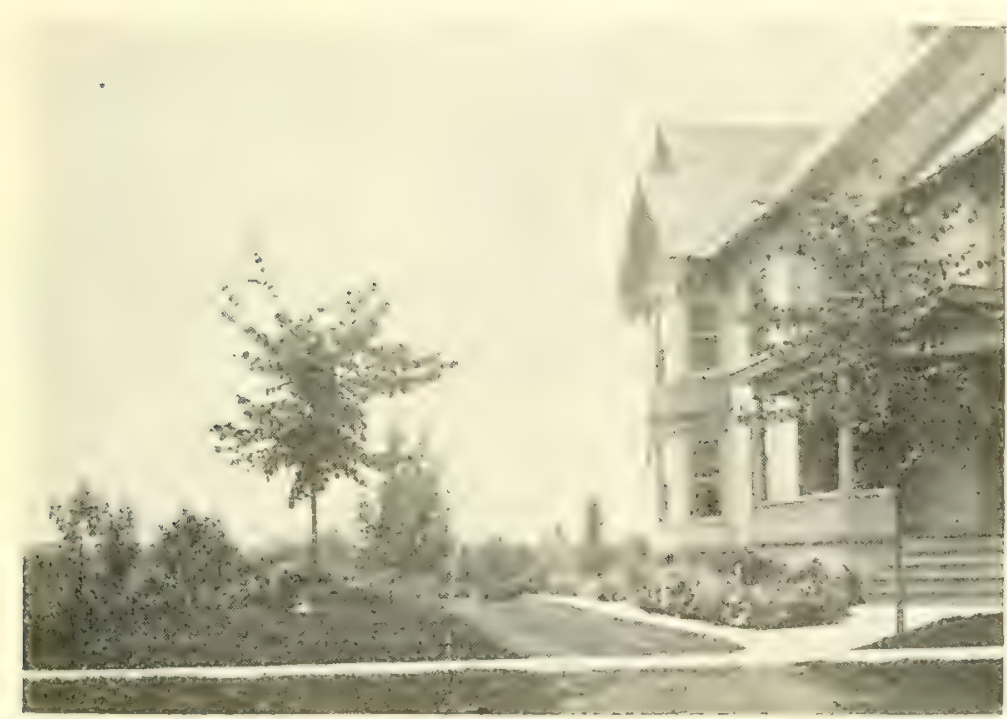

A Fine Yard

\section{From}

Geo. W. Hughes,

BroadalbiN,

NEW YORK.

I am sending by mail a few photographs that will talk belter than I can write. The soil is sandy and said to be very poor. As manure is scarce and hard to get, I used fertilizer extensively. The garden was largely flowers with a vegetable garden in the rear.

On one hill of Hubbard squash, I had seventeen large squashes,

one weighing fifteen pounds. The tomatoes are on poles, and I keep all the little ones picked off the vines. I have sold off this garden at the present writing $\$ 27.99$ worth of cabbage and cauliflower.

Mr. Field, if you could have seen my flowers and vegetables, I am of the opinion your eyes would have talked more than I can write.

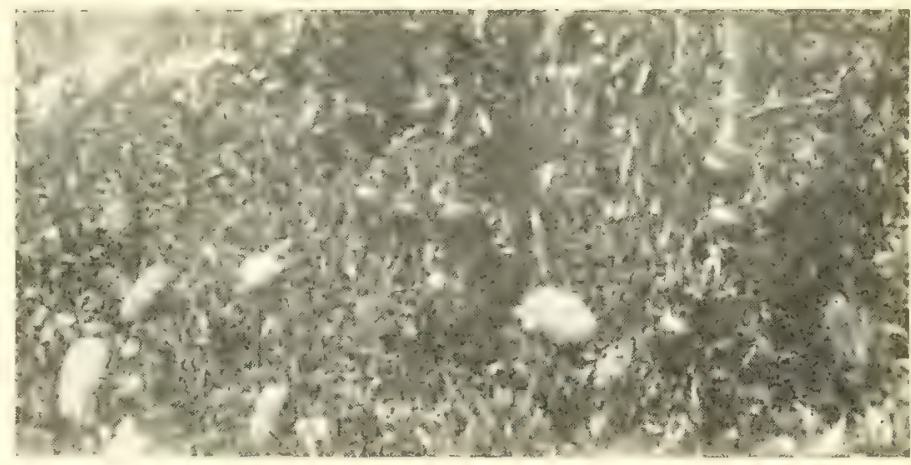

Asters and Early June Tomatoes in a New York Garden

Geo. W. Hughes, Broadalbin, New York.

\section{DROUTH STRUCK THIS GARDEN.}

From Mrs. D. B. Whisler, Creighton, Missouri.

Well, Mr. Field, it is impossible for me to send you any photos of our garden, as the drouth struck it just about the time we were thinking of having some raken and in less than a weeks time our garden was ruined. Also our flowers were all killed. The garden before the drouth hit it was as pretty as any you ever saw, for the size. Everybody was speaking about it looking so fine.

Mrs. D. B. Whisler, Creighton, Missouri. 


\section{EARLY TOMATOES, POTATOES, AND BEETS PAID BEST.}

From Miss Maud E. Keiser, LaKe View, Iowa.

I had a large garden and planted them all in rows $31 / 2$ feet apart, put onions, radishes, peas and lettuce in double rows about seven inches apart. My garden is 195 feet long and 35 feet wide. Last year father bought a one horse plow for one row to use in the garden,

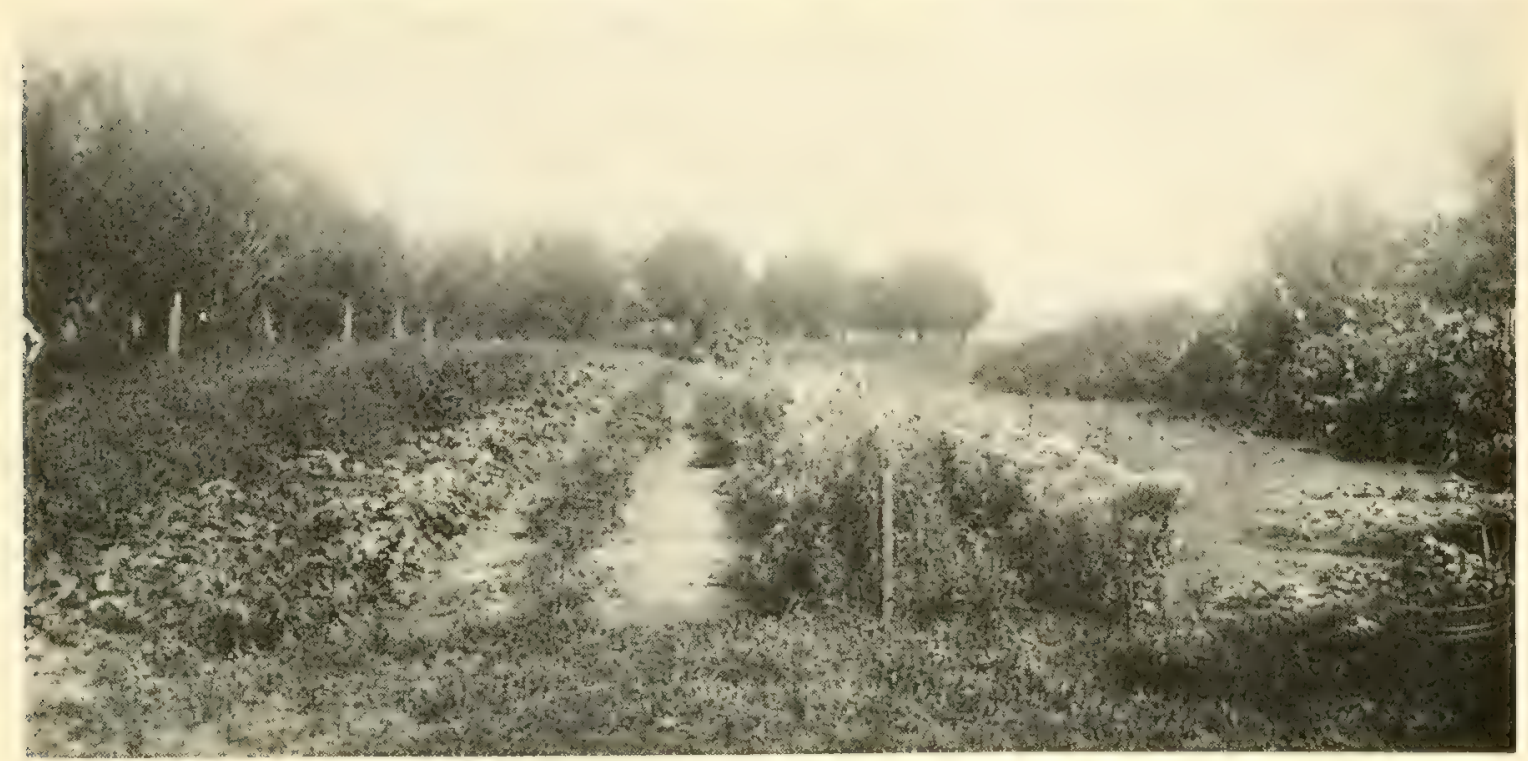

A Clean Well-Kept Garden in Iowa

and now I think I couldn't get along without it. After plowing it about once a week, I hoed the weeds out of rows with hoe.

We followed your directions about the hot-bed and it was wonderful how things did grow. I planted the seed in a hot-bed the last of March. The Iwentieth of April I put the first garden in. Two rows of early potatoes, cut up with not less than iwo eyes in a piece, about $11 / 2$ feet apart and six inches deep. In three weeks from that day they had blossoms buds on, and when all were budded, I hilled them up good and harvested eight bushels. After gathering potatoes, sowed turnips on part of the ground and harvested two bushels. 108 feet of set onions planted three inches apart in rows measured two bushels when gathered. Twelve feet of early radishes, and then when they were gone, put lettuce there. It is hard to estimate how many radishes and how much lelluce I had. We eat all spring, and I know there was over a bushel. One hundred twenty-five feet of Early June tomatoes transplanted to two feet apart, and the 19th of July had ripe tomaloes, and we never had tomatoes that bore better than they did, and such nice, ripe tomatoes, looked just like those in the seed book. Had tomatoes until frost came October 20th, and then there were quite a few on. Gathered 25 bushels of ripe tomatoes, sold $23 \mathrm{lbs} ., 5 \mathrm{c}$ per $\mathrm{lb}$., $\$ 1.15$; $18 \mathrm{lbs}$. at $3 \mathrm{c}$ per $1 \mathrm{~b}$., $54 \mathrm{c}$; total $\$ 1.69$.

I thought the early tomatoes, potatoes and sugar beets paid best, and if I could have sold the tomatoes they would have paid me a big sum for the ground I had in tomatoes.

Maud E. Keiser, Lake Vien, Iona.

\section{A GOOD PROFIT IN GARDENING.}

From Mrs. Frora E. Simmonds, Woonsocket, Rhode Island, R. R. No. 1.

In the first place, I sent to you for $\$ 1.00$ worth of seed. I raised peas, string beans, shelled beans, and quite a few dry beans for winter. Also potatoes, sweet corn and lots of nice tomatoes. The potaloes did not do well this year on account of the drouth. I had a strawberry patch and had strawberries for the table.

What I realized the most for was the raspberries. I sold them as high as $15 \mathrm{c}$ a pint and they came to over $\$ 70.00$. We had blackberries, currants, and gooseberries also, but not enough to supply the demand.

Our garden was the admiration of all beholders. I could not take any pictures because 1 don't have a camera.

Mrs. Flora E. Simmonds, Woonsocket, Rhode Island. 


\section{AN INTERESTING EXPERIMENT ON TOMATOES.}

From G. M. Stack, Center Harbor, New Hampshire, R. R. No. 1.

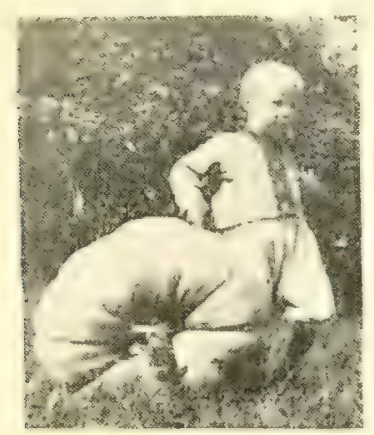

A good size Squash, weight 121 lbs.lafter it was picked a week. This came in a packet entitled Field's Col'ections of Mammotl

Pumpkins and Squashes.

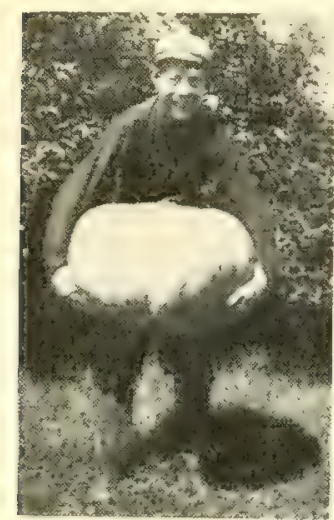

The Boy wants the Photographer to huriy and take the picture before be drops it

Coreless

Hummer ........... 6-20

Globe .............6. 6-21

Chalk's E. Jewell..... 6- 18

Burpee's D. Giant..... 6-30

Ea liana ........... 6- 6. 15

Field's Early June..... $6-10$

June Pink ......... 6- 15

Ponderosa .......... 6-22

Tenderloin ............ 6-... 6 . 24

Sutton's L. Yellow..... 6-30

Stone ........... 6... 6-22

Shenandoah ....... 6-24

I have always tried some new varieties each year and like to keep track of them to see if the seedsman has stretched the truth about them. This year I tried some of your new novel-

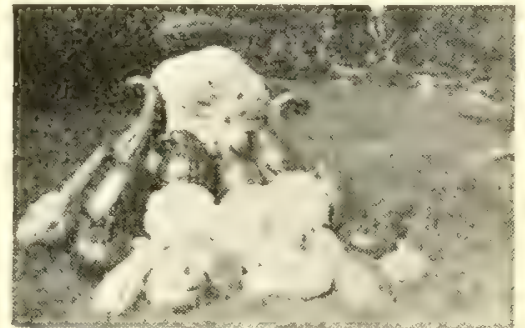

Variety of Squashes and Pumpkins for the Fair.

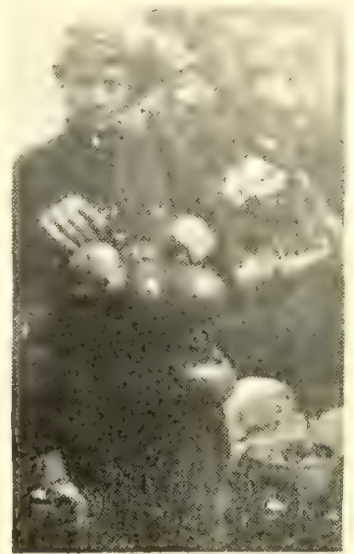

Field's Early June Tomatoes Note the size of them along side of the size of the boy's hand.

ties and think this one worthy of a report to you, telling you it behaved here.

Fields Early June Tomato.-_Seed planted in flat April Ist, seed up April 14th. Plants set in the ground May 20th, and ipe fruit on the vines July 28th. This variety bests its nearest competitor by ten days, and that variety is the Earliana. All the same day and had like attention. I tried 14 var this one, Field's Early June, is the earliest one of them all.

\section{Variety Test With Tomatoes 1911.}

(12 plants of each variety planted all at same time.)

\begin{tabular}{|c|c|c|c|}
\hline BLOOM & RIPE & YIELD & REMARKS \\
\hline $6-20$ & $8-19$ & 62 & A shy bearer here \\
\hline $6-20$ & $8-24$ & 80 & Better than (I) \\
\hline $6-21$ & $8-14$ & 98 & A good size tomato, smooth \\
\hline $6-18$ & $8-8$ & 115 & My choice as third \\
\hline $6-30$ & 9.15 & 46 & Smooth, shy bearer, late \\
\hline $6-15$ & 8- 7 & 112 & Second choice as Earliness \\
\hline $6-10$ & $7-28$ & 140 & First choice as earliness \\
\hline $6-15$ & $8-14$ & 108 & Good size, fine quality \\
\hline $6-22$ & 9. 9 & 60 & Largest, late and rough \\
\hline $6-24$ & 9. 6 & 72 & Better than above in quality, not so large \\
\hline $6-30$ & 9.40 & 36 & Fine flavor. Too late. \\
\hline $6-22$ & 8.10 & 112 & Smooth. Not as good quality as some others \\
\hline $6-24$ & 9.15 & 60 & $\begin{array}{l}\text { Good size and flavor. Requires a longer } \\
\text { season. }\end{array}$ \\
\hline
\end{tabular}

G. M. Stack, Center Harbor, New Hampshire.

\section{THE HOGS GOT THE POPCORN.}

\section{From Mrs. J. Bender, Rawson, Ohio.}

The family are laughing at me because I am writing. They said we had no extra plans laid out like the regular gardeners. I told them that I was going to write anyway. Our preacher was to our place when our sweet corn was the best, and he said we had ought to go into the truck business, but we live too far from market. 
My garden was set out in cherry trees. We farm a little between the trees until they get larger. Planted sweet corn three different times. We never sold any until this year. There was ready sale for it. The Early June tomatoes are the finest tomato I ever had, so nice and smooth.

The package of popcorn I got of you, I gave to the little boy. He had about 24 hills, and he took such good care of it. It stayed nice until about ready to husk, and the hogs broke in the patch one night and cleaned it all out. The watermelons were fine, that is what few we got. Part of them were:stolen. Some people won't buy seed or think of planting but depend on stealing. Don't know as I ever got any better seed, everything seemed to do so well.

Mrs. J. Bender, Ramson, Ohio.

\section{$\$ 62.60$ WORTH OF ONION ON QUARTER ACRE.}

From W. H. Rossean, Hamburg, Iowa.

1st. Cauliflower, iwenty-five plants, raised $100 \mathrm{lbs}$. good bright heads, made them into pickles.

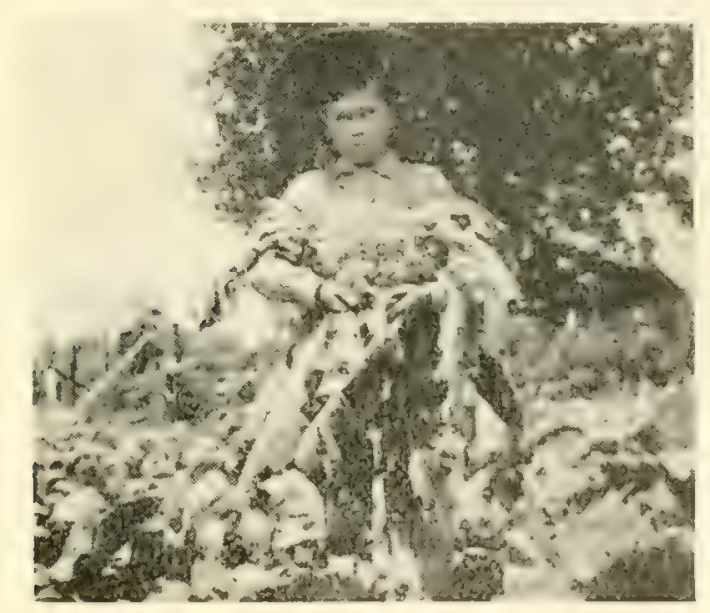

Fine Cauliflower in spite of a Dry Season

2d. Beans, five rows 100 feet long, produced 30 gallons green beans, sold part for $\$ 4.50$.

3d. Onions, one-fourth acre produced 50 bushel. That I sold for $\$ 62.60$.

4th. Tomato, seventy-five plants of Field's Early June that produced 1,200 pounds that averaged four cents per pound, amounted to $\$ 48.00$.

5th. Cabbage, 200 plants of early cabbage that made 400 pounds that I sold for four cents per pound which amounted to $\$ 16.00$. I have got 300 late that I haven't cut yet.

5ith. Potato, one-fourth acre yielded 311/2 bushels, at the present price, $\$ 1.25$ a bushel would amount to $\$ 39.40$.

I also raised some fine egg plant, but couldn't sell them for people didn't know what they were. Also raised an acre and a half of watermelons. They grew to maturity and began to ripen when the lice got on the vines and ruined them. Loss $\$ 200.00$. Also one hundred hills of muskmelons, Perfection, that averaged three melons to the hill that would bring me ten cents apiece on the market. Lice ruined them also.

W. H. Rossean, Hamburg, Iowa.

\section{A PROFITABLE BACK YARD.}

From Ruth Patrick, Randall, Kansas.

Our garden is only the fenced-in back yard. Early in March, as soon as the frost was out of the ground, we spaded up several beds and planted our carrots, parsnips and peas. The peas were up in about a week. We at once set out our onion sets, three quarts of red and three of white sets. We had some tomatoes started in the house but planted the most of our seed outdoors. They were mostly seed we had saved ourselves, gathered the year before.

When the weather turned dry and hot, our garden made no progress. The tomato vines grew, it is true, and even blossomed, but no fruit set on them until the rains came in the middle of August. Our onions stopped growing about the last of July, so we pulled them. We had been using them constantly since they got big enough to use, but we still had nearly a bushel, although none of them were as large as they should have been. Now, Sept. 25th, our tomatoes are bearing splendidly and will until frost.

Considering the season, however, and the fact that our garden was not irrigated, we consider that we have done fairly well. 


\section{CUCUMBERS PAID BEST.}

\section{E. P. Whitmore, Beaver Dam, Wisconsin.}

I am what you might call a near market gardener. That is, this is my first year at the business. I own fifteen acres of fine market garden land just one mile from Beaver Dam, a city of nearly 7,000 people, and I believe that I can make the business a success just as soon as $I$ get my second wind.

This year I have about three acres in garden truck and potatoes. In my garden I raised most all kinds of vegetables with very good success but in small amounts. My best paying crops were cucumbers, cabbage, carrots and Hubbard squashes. My best paying crop, considering the amount of land used, was my Davis Perfection cucumbers. I never saw anything like it the way those vines turned out the great big nice straight cukes. I had two rows about eight rods long. In spite of all the dry

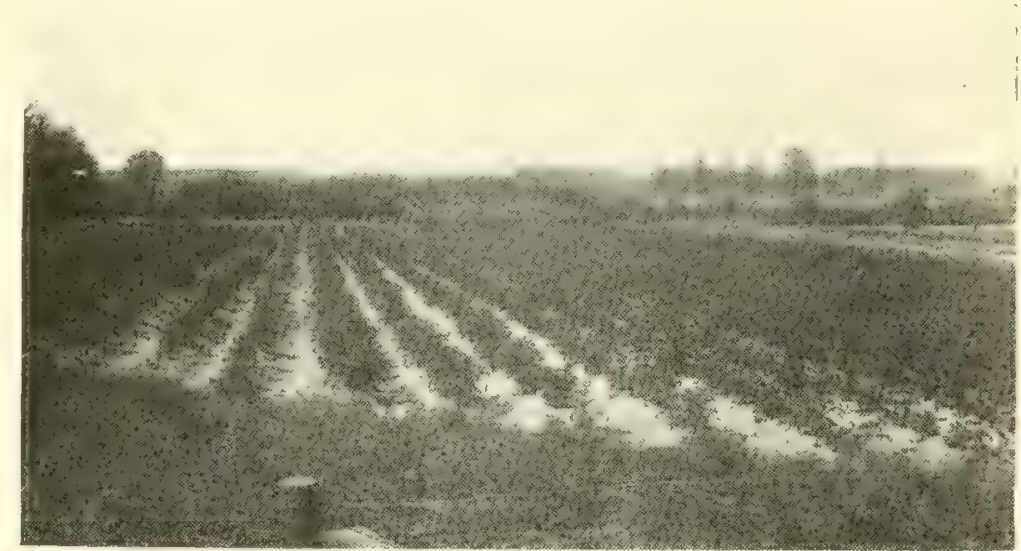

A Nice Clean Potato Patch weather we had in June, July and August, I sold nearly $\$ 30.00$ worth of cukes at an average of $\$ 1.20$ per bushel. I believe that little patch of ground will bring me in at least $\$ 35.00$ by the time they are all gone, or at the rate of $\$ 600.00$ per acre.

My cabbage is fine. I have about 800 heads of saleable cabbages, which at the present price of $4 \mathrm{c}$ each, will push the cukes hard for first place. My Hubbard squash are also fine. I have 150 large ones still on the vines, which at present price of 15 to $20 \mathrm{c}$ each will put the Hubbards right in the game along with the cukes and cabbage.

On vegetables grown from Field's seeds, I entered 20 varieties at the fair and took nine first and eleven second premiums. So you see I done fairly well for a beginner. With a good season next year I believe I can make some of the old hands sit up and take notice. As near as I can estimate now, my garden vegetables, taking one with another will average around $\$ 350.00$ per acre.

I forgot to mention my peanuts. From the one pint of seed you sent me, I have just dug a good peck of nice large peanuts. I would have had more, but the gophers took nearly half of the seed before I got onto their game. There is also one more vegetable I would like to call your attention to, and that is Gumbo. You said it was fine. Maybe it is, but honestly I would rather eat a second hand slippery elm poultice.

E. P. Whitmore, Beaver Dam, Wisconsin.

\section{BETTER GARDEN THAN HER NEIGHBORS.}

-From Maud Barber, Athelston, Iowa.

Considering the dry weather, I raised a good garden, but the corn and beans did the best as the dry weather did not seem to hurt them as it did the rest of the garden.

My garden is about as large as a residence lot. The rows are planted north and south, and on the east side I planted six rows of Peep O'Day sweet corn, then six rows of cabbage, two rows of cucumbers. I had a path that crossed the garden at an angle, so I planted pole beans on each side of this path until I had filled in the angles so the rows would run straight again. Then I planted four rows of Country Gentlemen sweet corn, two rows of muskmelons, two bunches of Lima beans, two of cucumbers and six rows of Evergreen sweet corn. After the corn came through the ground, I planted corn beans all around the outside of the corn. Across the north end of the garden I had my early garden of radishes, lettuce, onions, beets and plant bed and bunch beans.

While my garden did not do as well as it has other years, it was much better than most of my neighbors. 


\section{A MIGHTY GOOD REPORT.}

From Mrs. Dasha Mason, Falls City, Nebraska.

About me entering your Garden Contest, Mr. Mason, my husband, says it is foolishness for me to try, as I haven't time for such work having six little children and all my own work to do.

My garden is 180 feet east and west and 60 feet north and south. The first 40 feet, east end, was planted in lettuce, radishes, onions and beets and seed bed. Put melons on after lettuce and radishes. Put Kohl Rabi after green onions. Planted muskmelons on side of bed, too. Cot full crop of lettuce, radishes, and now have 22 nice ripe melons from same ground and 60 more on vines measuring from 12 to 24 inches apiece. Got full crop of green onions and Kohl Rabi off of same ground, and now have 30 nice muskmelons on the same bed. Have had two ripe ones.

Next 40 feet in large Flat Dutch cabbage and tomatoes, 400 cabbage and 200 tomatoes. Cabbage is heading nice and tomatoes loaded. Have had lots of ripe ones since July 20 th.

Next 21 feet in sweet corn, popcorn with Kentucky Wonder beans planted with it, a full crop of both. Next 12 feet cucumbers, just fine. Next 6 feet, bunch beans. After they were picked, pulled and put turnips. Next, one row beets and peas and now in turnips.

I have had two crops and some three on all except cabbage and tomato patch. I have got the stuff right here to picture, too, and one girl and five boys to help make a picture good measure.

I have sold nothing so far except 200 plants. I have nothing to sell except tomatoes and pickles. I hoe my garden every ten days. I have no flowers or frills, as we are renters and must work very hard.

Mrs. Dasha Mason, Falls City, Nebraska.

\section{\$280.00 FROM TWO ACRES.}

From Mabelle S. Hooper, 116 Locust St., Danvers, Massachusetts.

All surplus fruit and vegetables find a ready market with us as we are near town and offer only first-class goods. We have a particularly fine location for earliness, being situated between two hills.

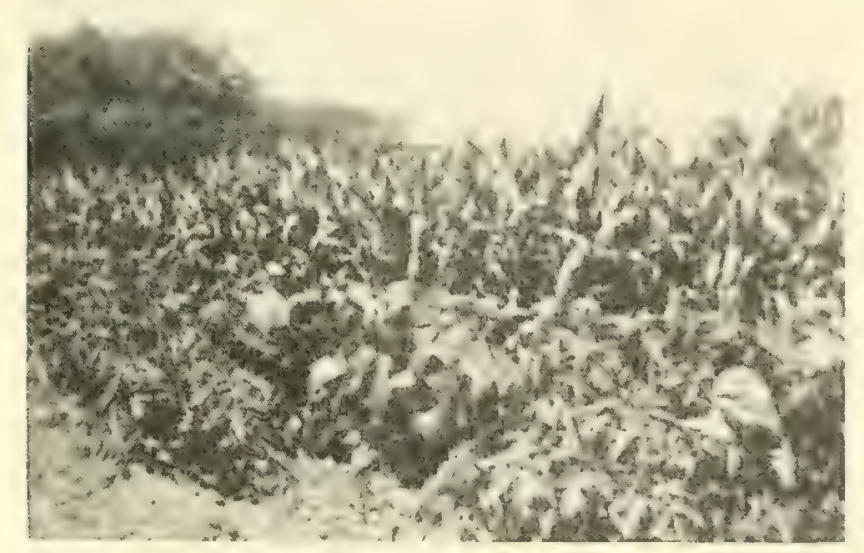

All work is done by my husband and myself, which means not much time for play, but perfect health and much happiness. This fall we have built a fair sized greenhouse and hope in the future to give our whole time to market gardening and flowers.

This last spring my husband was operated upon for appendicitis and was sick for a long time. Anxious to relieve him, I ordered the seeds myself, saying nothing. After they came, I found in my ignorance I had ordered tomato seed alone enough to plant our whole farm. We planted them, however, and sold plants. The

Corn, Beans, and Tomatoes did well in Mass.

Early June we kept ourselves and never saw such a setting of fruit on any tomatoes.

Our garden consisted of about two acres planted in rows of 100 feet. After furnishing an abundance for our table, with the cellar full for winter's use, we made about $\$ 280.00$ from the two acres.

Mabelle S. Hooper. 116 Locust St., St. Danvers, Massachusetts.

\section{NOT A LARGE GARDEN BUT A GOOD ONE.}

Ffom Ella Underbrink, Chandlerville, Illinois.

Off of one hundred tomato plants, I raised about ten bushel of tomatoes, the largest ones being about 14 inches in circumference. We raised over 50 bushels of potatoes off of one- 
fourth of an acre. The largest polatoes were from 14 to 16 inches in circumference and 9 inches in length. I raised a few muskmelons, the largest being 26 inches in circumference.

There was about eight or nine loads of watermelons. We sold three large loads that brought $\$ 60.00$. The largest melon was 50 inches in circumference and 36 inches in length. The rest we used, fed to the hogs, and some went to waste. I raised one hundred heads of cabbage, the largest head being 35 inches in circumference. There was a few pumpkins, the largest was 90 inches in circumference.

\section{Ella Underbrink, Chandlerville, llinois.}

\section{SOME BIG TOMATOES.}

From Manuel E. Vierra, Mission San Jose, California.

These are the largest tomatoes I have ever raised or seen. A neighbor of ours had some last year, and I asked him for a few seeds and he gave me one tomato. As few seeds as it had, I saved them all and sowed them early in a box. This box was set by the well where it could easily be watered every night. Evening after evening these seeds were sprinkled until they were about two or three inches high. 'It was then April and the danger of frost was over.

The little tomato plants were replanted an equal distance apart. To keep out weeds and the ground fresh, it was hoed quite often. If the best results are expected, the ground should never be neglected. They are as large and the largest 1 have ever seen.

Manuel E. Vierra, Mission San Jose, Calif.

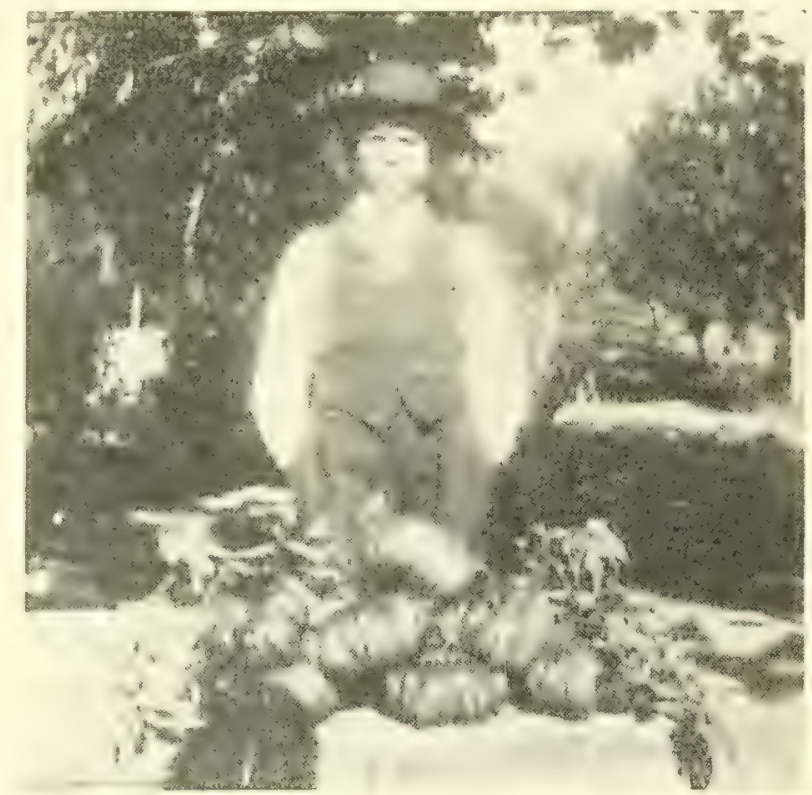

Tomatoes larger than saucers. A little rough but good.

\section{JUST A LITTLE TOO DRY AT SWEETWATER.}

From Mrs. L. A. Bailey, Sweetwater, Texas.

The drouth in this part of Texas just about put us out of the garden business. Yet, I cannot refrain from wriling you a liille of our experience, as you seem to want to hear from us all whether we succeed or not. I tried very hard.

We had two gardens, one depending on rain alone planted to early potatoes, corn for roasting ears, six varielies of peas, planled for a succession, string beans, squashes, peanuts and cucumbers and cantaloupes. We also set out hundreds of tomato planis and cabbage plants in this garden, but after growing beautifully for awhile, the drouth finally took it all. We did, however, get about one-half dozen messes of peas and string beans.

The other garden was situated on slightly sloping ground and near a well and windmill, which also failed to fill our expectations during the extreme dry hot weather, and we lost all that excepting the early crop.

Mrs. L. A. Balley, Speetwater, Texas.

\section{THE WAY TO GROW A GOOD GARDEN.}

From John S. Cox, Thayer, Indiana.

I plant in rows so I can tend my truck with a horse. Each variety is along in rows so as to connect, making it more convenient to plow with less turning.

I would have given $\$ 10.00$ if I could have got some pictures struck of my truck patch.

I had out one acre of cucumbers of which brought me \$115.66. I worked each row out with a single shovel, then dropped my seeds one step apart in rows, $6 i / 2$ feet beiween rows. I planted my seeds the last of June, cultivated well until in bloom, then picked my first the first of August and last picking the tenth of September.

JoHn S. Cox, Thayer, Indiana. 


\section{AND PEANUTS CAN BE GROWN IN IOWA.}

From Chas. Garrean, Percival, lowa.

I had about six hundred cabbages, and they were fine. I planted them in the usual way and kept the soil well loosened and hoed. I sold about \$12.00 worth. The tomatoes were good. We picked eight bushels off of 60 plants. Our Kohl Rabi grew to weigh three pounds and they stood the dry weather fine. Your dry weather cauliflower is the finest I ever saw. It grew to weigh two pounds. The salsify was fine, too. The beets stood the dry weather fine, three was all I could get in a bushel basket. I planted 26 hills of peanuts and got a half a bushel. We picked two bushels of vine peaches off of ten hills. Our radishes were dandies, they grew about $11 / 2$ feet long, but of course they were not good after they got so big.

Now as I have told you about all that I raised that amounted to anything, I will tell you how I raised it. I planted it after the usual way and kept the weeds out and kept the ground well loosened and mulched, and that is all there is to it. Of course I used good seeds. I plant nothing but Field's seeds.

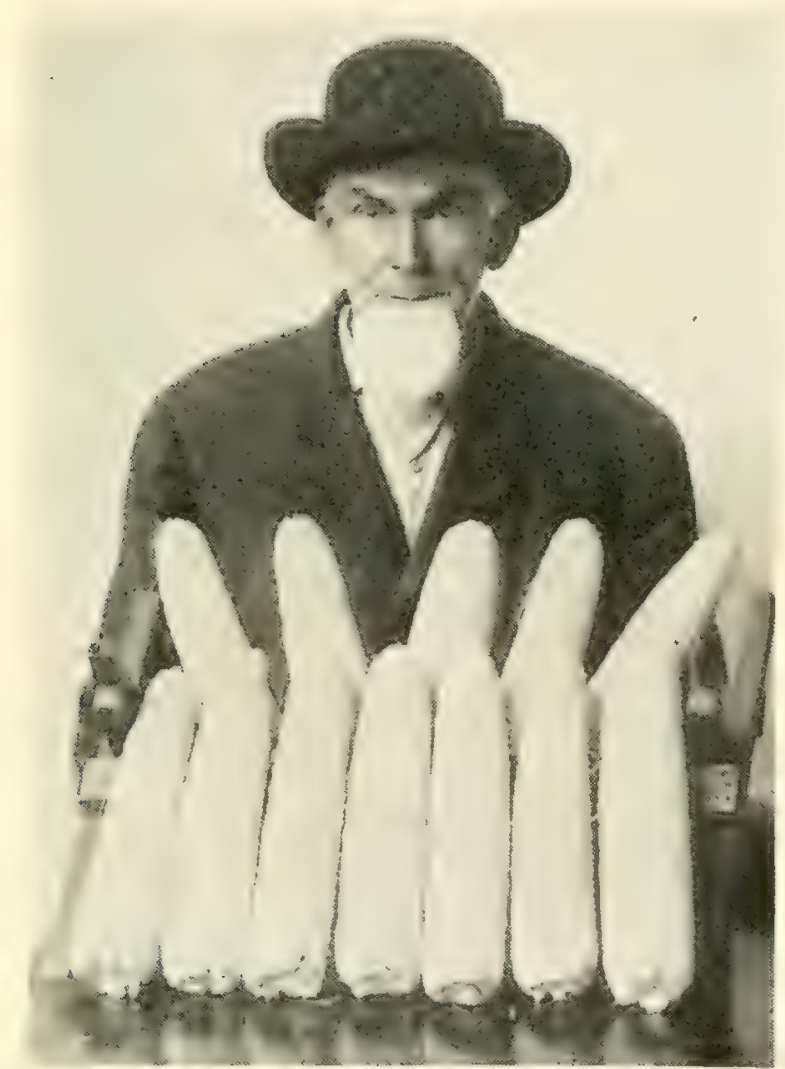

An Uld Time Corn Grower and some mighty good corn
Chas. Garrean, Percival, Iona.

\section{\$25.00 WORTH OF STRAWBER-} RIES FROM 5 SQUARE RODS.

From D. E. Moffett, CORNIng, IOWA.

I have eight or ten little patches which I have used this year. Some of the crop is all harvested. I sold $\$ 25.00$ worth of strawberries from five square rods, besides about 15 quarts canned and what eight of us ate. From another small patch sold $\$ 5.00$ worth of peas besides what we ate. I have done all of my work by hand except the plowing of the ground.

I have several varieties of new potatoes, and I have dug some four bushel or more of early ones and have two bushel set aside for the State Fair.

I won a piano at the Corn Contest, also $\$ 10.00$ on a single at the corn show last December in Des Moines.

\section{E. Moefett,} Corning, Iowa.

\section{FIELD'S SEEDS BEST, AND SHE IS OLD ENOUGH TO KNOW, TOO.}

From Mary T. Dupes, Manville, Wyoming.

Dear Sir: I feel just like telling you about my garden. I had just the nicest garden around here. I wish that you could see it. There is everything in it, and good things, too.

I have just one-half acre in my garden. The rows are clear across the patch. I worked it with a little garden plow when it was small and then with a little mule. Will send you a photograph of it in a few days. You will say it is grand for an old lady 64 years old to make. I got the seeds from Henry Field, every one of them. They certainly are good seeds. I have had seeds from ever so many firms, and Field's seeds beat them all. You see $I$ am living in Wyoming where it don't rain. My onions are the nicest in this county. I can't say too much good about the seeds.

MARY T. Dupes, Manville, Wyoming. 


\section{GOOD SUCCESS WITH MELONS.}

From H. England, Quitman, Missouri.

About May 30th I was completely hailed out, but I went right after it, got new seed and planted over, and I am reaping my reward now.

I had about two acres of watermelons, Kleckley Sweet, Halbert Honey and Harris Early and some Princess. Then, I had about one-half acre of muskmelons, cantaloupes, Daisy Perfection and Banana. When I began to replant, I just left the old stalks and planted belween. It did not seem possible that they could ever come out, but I want to say in about three days it did not look like the same patch. Well,

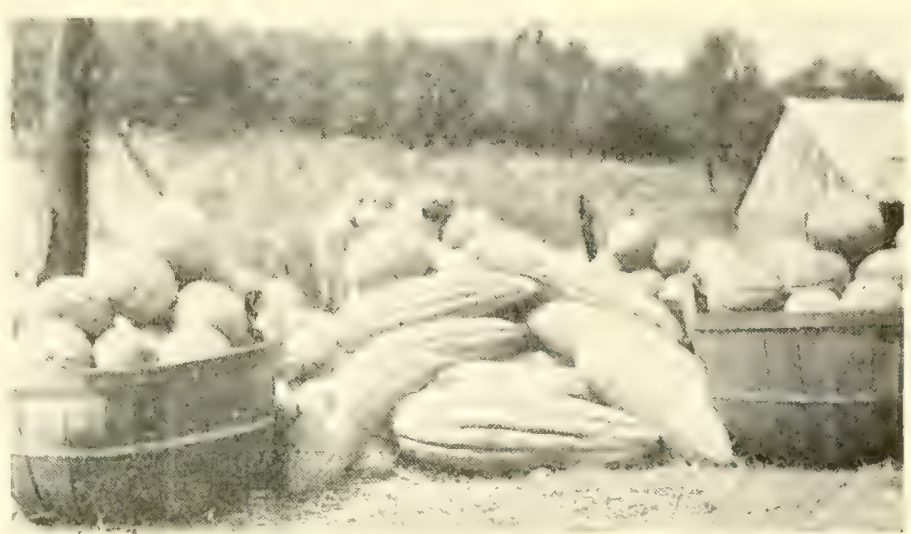

75 Dozen Muskmelon worth over \$io from a single picking on 1-2 acre Friend Field, I don't believe ou can kill them at all, anyway not with hail stones. When the new ones came up I certainly had to fight. The little siriped bug was there and all of his kin. I worked early and late with lime and all kinds of remedies until I got the vines ahead of them. The very hot days of August willed my vines, and I think I lost about

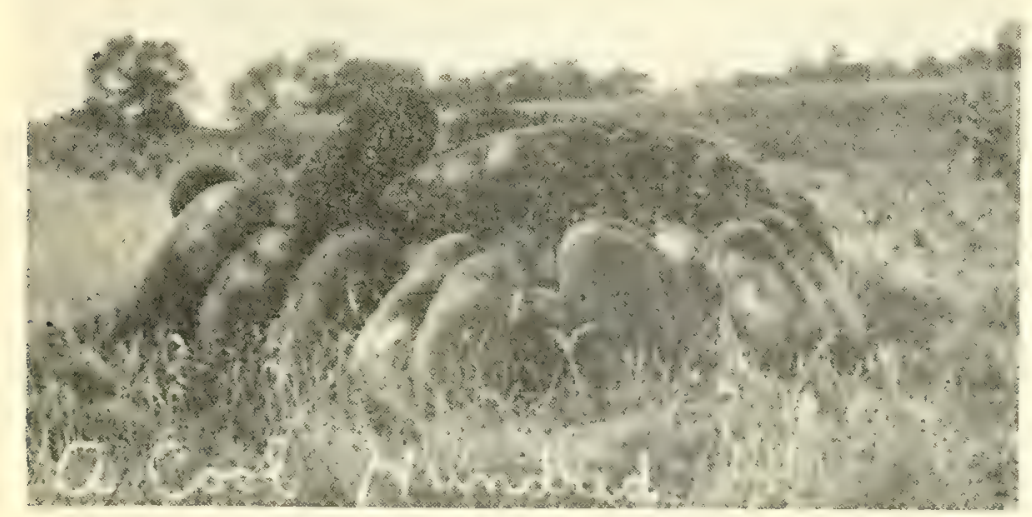

A Hundred Kleckley Watermelons at one picking $\$ 75.00$ worth of melons. I sold my first load of melons August 9th. I enclose you a picture of my melons. My muskmelons will speak for themselves. The seed I got from you was very fine. Of this one picking of seventy-five dozen, fifty-five dozen was sent on one load.

I certainly do feel thankful for the truck that I raised, taking into consideration not having any rain from May 30th to July 22d. Potatoes were a complete failure. I only raised about thirty bushels on two acres.

I also send you a picture of my Short Orange Cane. I am so proud of it. You will see it was not headed out, but is now a great bit taller than when the picture was taken.

H. England, Quitman, Missouri.

\section{GOOD BLACKBERRIES ANYWAY.}

From Mrs. Agnes Ducoin, Valley Center, Kansas.

We live in town and have 5 lots. We have a little of the best of everything planted. Our blackberries bore this year for the first. We would have had a big crop if we had got rains, as it was I picked 25 gallons.

My flowers could not do anything, the sweet peas burnt up. I will have a good many onions but they ripened up early at half size. I am gelting 5 cents a lb. for them. I took a bushel to the store last week and have a sack full ready. for to take today.

If we have had rains as we needed, things would have been fine, as it is we must submit to it.

Mrs. Agnes Ducoin, Valley Center, Kansas. 


\section{FOUGHT BUGS, BLIGHT, AND DROUTH.}

From Mrs. O. W. Holmes, Millport, New York.

This garden, the first I ever had, is in three patches around our suburban cottage home. During the winter, I drew my plans, bought my seeds, started tomato, celery, pepper and cucumber plants in window boxes in the house and got my set of garden books ready. The garden was plowed as early as a cold, late spring would permit, the ground dragged, and on a warm bright day I took charge.

I dropped the peas two inches apart in each furrow. I always cover seeds as deep as three times their diameter. I used one pint of seed for my 120 feet of row. The first picking was on June 9th and the last on July 13th. The yield was forty-nine quarts. On July 14th I spaded the vines under, added more fertilizer, and transplanted from my cold frame the celery plants I had grown in the house. This gave me 60 heads of White Plume celery.

I fought bugs and blight and drouth. I had my full share of tired back and feet, blistered hands and lame wrists until I learned how to manage in my two hours toil from four to six in my garden nearly every morning. But the keen enjoyment of the fresh, sweet morning air, the steadily increasing strength, the renewed health, the pleasure gained in watching green things grow, the satisfaction of having really fresh vegetables for my table, and the way I appreciated the long rows of canned vegetables, more than compensated me for the toil and time spent.

Mrs. O. W. Holmes, Millport, New York.

\section{SUCCESS WITH TOMATOES IN OKLAHOMA.}

From Mrs. M. E. Broome, Mountain Park, Oklahoma.

I have been the most successful gardener for the last seven years in a radius of forty miles or more, and I have been the only person that has raised any vegetables in this part of Oklahoma to speak of, for the last three years. I have had vegetables to sell every week

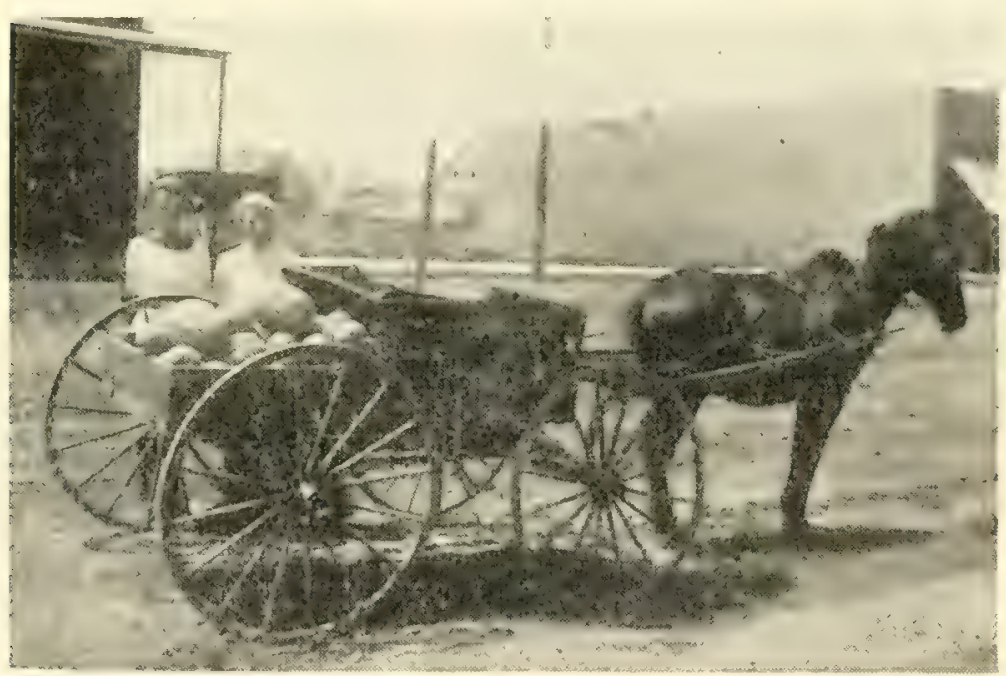

A Good Load of Vegetables in the Dry August Weather in Oklahoma since the fifteenth day of April, and still have about fifty or sixty dollars worth to sell. I sell to the women at their homes, and as almost every family in the two towns of Mountain Park and Snyder are my customers they are my witnesses to the truthfulness of the above facts.

I sow my tomato seed in a cold frame about the 20th of February in shallow drills six inches apart and cover them one-half inches deep. I water them good with warm water and cover them up every night to keep in the heat. The ground having been prepared by plowing it again as deep as the plow will run and harrowed smoothly, it is laid off in rows one-half foot apart and the plants are set two feet apart in the bollom of these furrows. This deep setting and having the plants strong by growing them in the sun and wind without artificial hat is why they always set fruit. I take my plants up in bunches and select the largest and set the small ones back in the bed for the later setting. I have them cultivated every week to create moisture whether they ned it or not until they are too large to get through without injuring the vines. My late tomatoes are treated precisely the same as the early ones, only they are set four feet apart each way. I set my early cabbage and pepper the same way I do my early tomatoes.

I watch my garden every day. When the rabbits begin on my beans, peas and cabbage, I put Paris Green on them with a hand spray. I put five heaping tablespoonsful to a medium 


\section{THE BOOK OF A THOUSAND GARDENS}

size tub of water. They will eat one more mess and quit. I use it on my cabbage to keep the worms off, too, and on my cucumbers, muskmelons and watermelons to destroy the striped cucumber beetles and on my Irish potatoes to destroy the bugs on them. I saved my garden with Paris Green. I used about eight pounds this summer. I find the melon aphis to be the hardest thing to control, as they

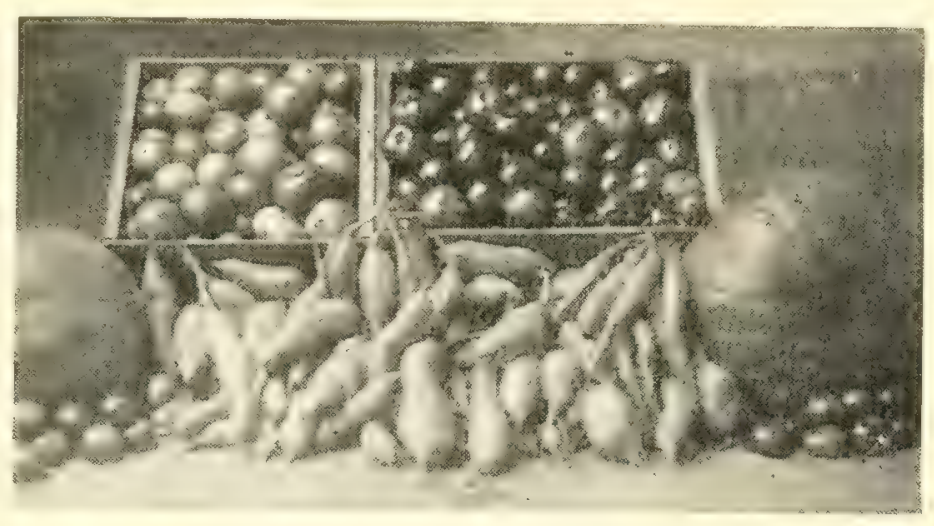

Tomatoes. Squashes and Sweet Potatoes from a Woman's Garden suck the sap out of the vines. There isn't anything that will poison them. I watch my vines every day and the first vines I find affected, I pull up and bury them. I put lime in a gunny sack and pass through the patch and strike the bollom of the sack lightly on the ground among the vines, and the lime will fly up under the leaves and on the vines and check them. I also use ashes the same way.

My earliest muskmelon vines have produced melons ever since July. I raised the largest muskmelons this year I have ever seen. One measured $233 / 4$ inches from the stem to the blossom end. I will send a photograph of scme of them. I had $11 / 2$ acres of watermelon and muskmelons and cantaloupes. Sold about $\$ 20.00$ worth of watermelons and about $\$ 40.00$ worth of muskmelons and cantaloupes, and sold about $\$ 200.00$ worth of tomatoes. Had about ten hundred cabbages and sold only about $\$ 25.00$ worth. My other vegetables brought about $\$ 65.00$. Having sold in all $\$ 350.00$, which was extra good considering the drouth.

Mrs. M. E. Broome, Mountain Park, Ollahoma.

\section{A HUNDRED WORDS NOT ENOUGH. GLAD TO HAVE YOU COME WITH MORE.}

From Mrs, F. M. Wilson, Balfour, North Dakota.

A lady friend of mine in lowa sent me a few packets of Mr. Field's seeds. Among them was a packet of Field's Early June tomato, which proved a decided success away up here in North Dakota. She also told me about this contest, then I wrote Mr. Fields for particulars. I entered Garden Contest one time, but the editor only allowed us one hundred words, and what is one hundred words to a woman, so you may know I didn't win out.

My garden is $8 \times 12$ rods square enclosed in a chicken proof fence, I plant as soon as the ground can be worked. I make a shallow trench for all small seed, and then fill with water. This gives the seed a moist bed and no time is lost waiting for rain. I plant peas five inches deep and sow very thick in drills. This always gives me the second and third picking. I soak sweet corn seed several hours before planting, as this puts it ahead several days. I always sow parsnips in the fall. This always insures a crop, as it takes lots of moisture to grow parsnips.

I always have excellent success with cucumbers. I only plant two varieties, the Long Green and Early Cluster. I never throw up a hill, I believe in level cultivation. This year my cucumber patch was $2 \times 6$ rods. I planted five ounces of seed in this and picked sixty gallons of fruit.

I was told I couldn't raise celery in North Dakota, but I wasn't satisfied till I tried it myself. I sow the seed in a box in the house the first of March. Celery requires lots of water. After the danger of frost, I transplant in the garden. When the plants are large enough I replant in trenches. I wrap in paper and then earth up to bleach. Later, I remove to cellar, wrap in new paper and pack in dry sand.

This year my carrot bed was $2 \times 9$ rods, and from this bed I dug 88 bushels of carrots. I sowed the Ox Heart, Danvers Half Long and the Mastidon.

Mrs. F. M. Wilson, Balfour, North Dakola. 


\section{HERE ARE SOME GOOD IDEAS.}

From Mrs. A. Bentley, Fayetteville, Arkansas.

I think a garden should be planted in rows. It is easier to cultivale in every way. I have nearly one acre in garden. Have four rows of potatoes, two of beans, two of tomatoes, two of corn, two of onions, two of beets, two of radishes, one of carrots, one of salsify, okra, parsnips, and two of peas. The remainder in cabbage and other plants.

It has been pretty dry, but we have had rains, so I look for a beautiful garden, as things grow so fast here in the Sunny South.

The keynote of successful gardening is to stir the soil, stir it often with four objects in view. 1st, to destroy weeds; 2 nd, to ventilate the soil; $3 \mathrm{rd}$, to enrich the soil by action of air; 4 th, to retain the moisture by preventing its evaporation.

Mrs. A. Bentley, Fayetteville, Arkansas.

\section{A FINE WISCONSIN GARDEN.}

From Mrs. Aug. Milke, Potosi, Wisconsin.

My garden is about three-fourths of an acre. I have it plowed in the fall and use the

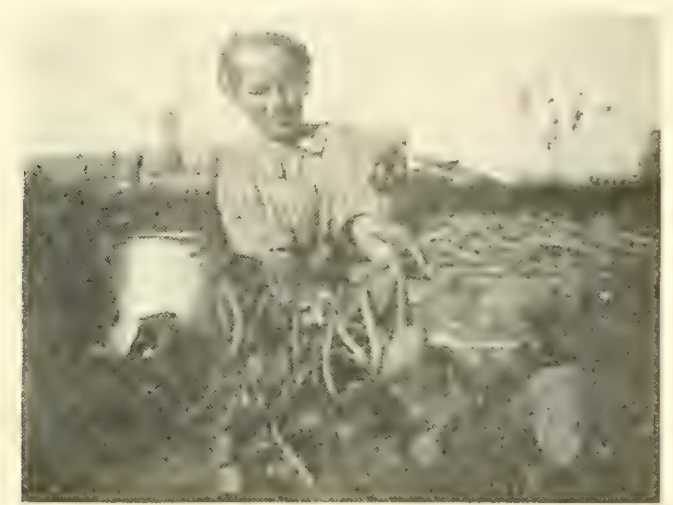

Field's First Early Green Beans. A Tubful and a Bucket full at one picking from two short rows.

I do not sell any of my crops so I cannot tell you which I made the most of, and the reason 1 don't is because nearly every one in this community raises their own garden. You have plenty chances to give away but nothing for sale.

Another thing I want to call your attention to is my Cauliflower. I had the largest and whitest cauliflower this summer I ever saw. I know some of the heads would have taken the prize, so large and white.

Mrs. Aug. MiLke, Polosi, Wis. disk in the spring. I think that helped me out quite a bit this summer. I raise about everything anyone wants to eat in the line of vegetables. In addition to my vegetables, I raised about as nice an aster bed as anyone wants to see.

I have Field's Early June tomatoes. That is about the nicest tomalo I want to have. It is not quite as large as Ponderosa, but I have tomatoes much earlier. Our family is quite large and all fond of tomatoes. I also realized more off your green pod bush bean. I picked a large wash tub and a three gallon bucketful off of two rows. I put up fifteen gallons in salt for the winter. Last year I had $31 / 2$ gallons off the same amount planted.

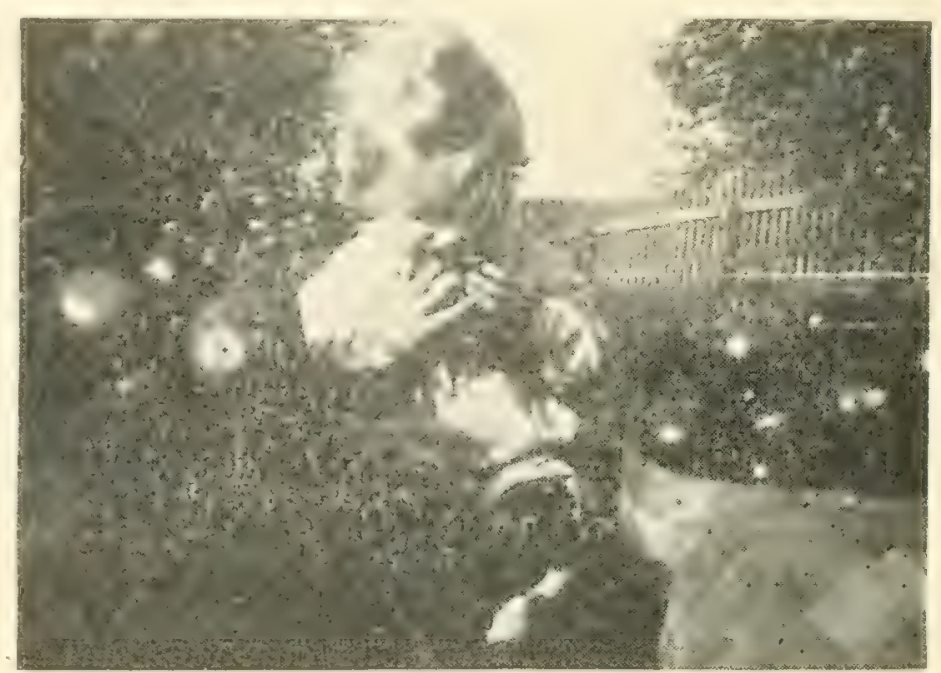

Early June Tomatoes and a small girl who is right on the job

\section{JUST THE IDEA FOR A DRY YEAR.}

From Mrs. A. E. Townsend, Bloomington, Nebraska.

I had a fine garden. The dry weather did not hurt it much as I would hoe it after every little rain to hold the moisture, and it did fine until the fifth of August, when it got too much water, as my garden was on the Republican river bottom and the river got out of its banks and stayed out seven days.

Mrs. A. E. Townsend, Bloomington, Nebraska. 


\section{QUARTS OF STRAWBERRIES FROM \$1.00 WORTH OF PLANTS.}

From J. J. Schroeder, Humphrey, Nebraska.

Our garden is about 80 feet square and is really intended for home use only. All hopes of having a fine garden and sending you a number of good photos were shattered when on June 25 th a severe hail storm beat things almost into the ground. Contrary to our opinions, however, everything seemed to get new life, and came out wonderfully. We have enough of everything for our own use and some to sell also.

From $\$ 1.00$ worth of Henry Field's strawberry plants set in the spring of 1910 we realized over 100 quarts of fine, large strawberries. Have sold between nine and ten dollars worth of onions, besides what we kept for our own use.

Our garden has never been manured although it is on bottom ground and gets a little drainage from an old strawpile. We attri-

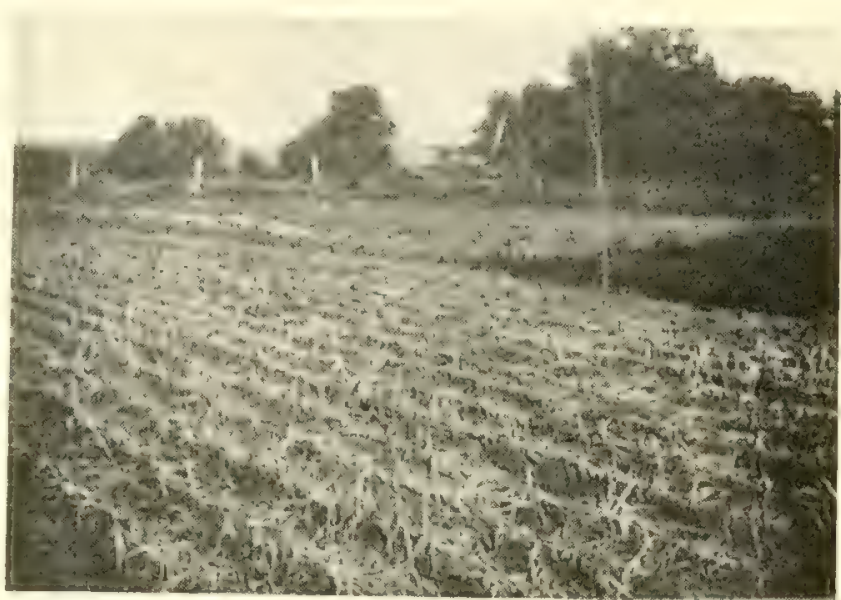

What the hail did to one promising onion patch. It came out however and made oven $\$ 10$ worth of onions after all. bute much of our success with our little garden to the seeds which are all from Henry Field Seed Company.

\section{J. J. Schroeder, Humphrey, Nebrasha.}

\section{HOW IS THIS FOR A 13 YEAR OLD BOY?}

From John B. Carter, Roy, Washington.

I rented a piece of ground big enough to plant a five cent package of cucumber seed. The ground was plowed May 12th. There was a mixlure of cow, horse and sheep manure spread over the ground thin and plowed in. I took the garden rake and raked the patch level, then took the pointed hoe and made three rows three inches deep, then put in about a bushel of pulverized hen manure, then kicked in a little dirt and planted the seed May 20th.

On June llth it froze off about two-thirds of the plants, so that saved me the trouble of thinning them. I hoed them three times, the last time I hilled them up a little. We picked our first cucumbers August 14th. I sorted the cucumbers into three sizes. Number one, five inches and over, number two, three inches to five inches, number three, everything under three inches. Of number one, I had 244. These I sold at $25 \mathrm{c}$ a doz. Of number two, there were 325 , and of number three, 366. The reason there were so few was because they were froze black September 18th or 19 th.

John B. Carter, age 13, Roy, Wash.

\section{HERE IS A BOY THAT WILL MAKE GOOD.}

From Geo. B. Carter, Roy, Washington.

The next time I try for a prize, I'll take one thing that won't freeze, for this country beats anything you ever heard of. You can depend only on July for no frost, and two years ago it froze mama's cucumbers the second night of July.

For my garden, I took Red beans. Pappa plowed up a piece of ground that had never been plowed. I had to sit on the plow beam to help plow up rocks, and say, we had all two horses could draw on a sled of stones off what ground it took to plant a cup of beans. I raked the ground smooth with potato hook, as there was too many rocks to use a rake. I put on a gunny sack of hen manure and hoed that in. Made the rows with a pointed hoe, and planted beans May 19th. They came up fine, and the frost of June 19th didn't kill them, but they didn't set many beans. I kept them hoed and used the small hand cultivator on until they were big enough to keep ahead of weeds. So off of one pint of beans I have only five quarts of shelled beans.

George B. Carter, age 11, Roy, Washington. 


\section{A 'LITTLE GIRL AND HER BIG SQUASH.}

From Miss lillian Poss, Aurora, Illinois, R. R. No. 3, Box 46.

I lake great pleasure to write you a little about my nice little garden. It was beautiful, I must say. You ought to have seen the wonderful squash we had in our garden. Everybody

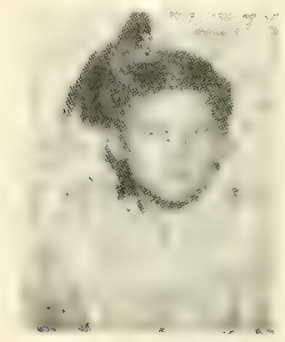

The little girl - who raised a $951 \mathrm{~b}$. Squash asked where did you get that seed? My Grandma, who is nearly eighty years old, came to see our garden and she said she never seen such nice squash in her life. I am thirteen years old, and I thought I was strong, but I could not move it. So my brother tried to help me carry it home, but we were surprised for we could not lift it. Then we had to call for papa. You know he is a very strong man, but it made him sweat to get it home. We weighed it and you would be surprised to know how heavy it was. It weighed just 95 lbs. That is the honest fact.

The cabbage was so nice. It only took four dozen for a big barrel of sour kraut. And all the rest of the seeds were the best we ever had, and we are glad that we ever got to know the Henry Field Seed Company. So must close for this time, with best wishes to you.

Miss Lillian Poss, Aurora, Illinois, R. R. No. 3, Box 46.

\section{TOMATOES DO WELL AT AFTON, IOWA.}

From Miss M. McElroy, Afton, Iowa.

Our garden is about half of an acre. The way we prepare our soil to plant anything is to plow the ground early in the spring. Now for the tomatoes. The first thing we do to them in the spring is to make a small bed, and when they are about four inches high we set them out, hoe them and keep the weeds and grass out. We are getting about a half a bushel every morning now and will until it turns cold. We sold them at $\$ 1.00$ per bushel. Mamma has got about 100 quarts canned.

Miss M. McElroy, Afion, Iowa.

\section{SOLD OVER \$40.00 FROM A GARDEN 60x75 FEET.}

From Frances E. Nissley, Middleton, Pennsylvania.

I made a success of my garden this year because it was a good spring for it. I will name some things I grew, asters, gradiolus, lilies, sweet peas, dahlias and geraniums. The chrysanthemums are not in bloom yet. I keep account of my flowers and I have made $\$ 6.75$.

The vegetables 1 raised two crops out of my garden. When the spring onions were fit to take out, I put celery there, and when early cabbage was over put turnips there, and after early potatoes put late cabbage in between the potato rows. I never had such cabbage before, and when I dug the potatoes I got two bushel and a half and got $10 \mathrm{c}$ a

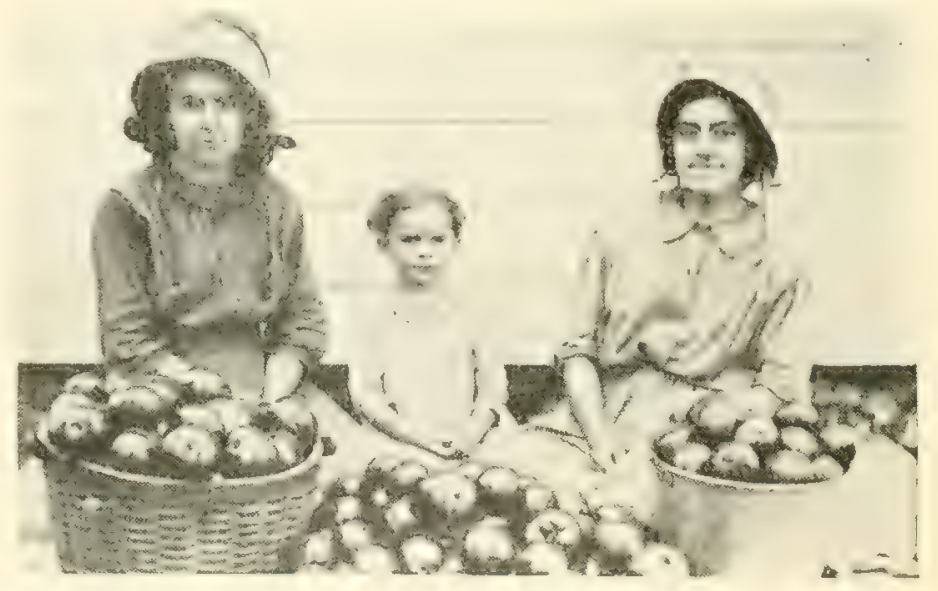

Some hustiing Pennsylvania Girls and their Early June Tomatoes. They sold over $\$ 40$ worth of vegetables from a ga:den only $60 \times 75 \mathrm{ft}$. quarter peck for all of them.

My garden is $60 \times 75$ feet. I tell you it takes work to keep it clear. The Early June 
tomatoes I got from you, I never had such nice tomatoes before. I liked your kjnd the best of all because they have such a nice shape and such a good fleshy laste. I got a photo taken of them with my sisters and myself in it. Had just gathered them. I had one hundred and seventy-five plants and got ten bushel in all. They sold real good too. I made $\$ 8.00$ on my tomatoes.

I just wish I could have taken more photos, but I could not get the supplies for my camera. I keep an account. I made in all $\$ 40.00$ of different things. I tell you such little things count a good bit.

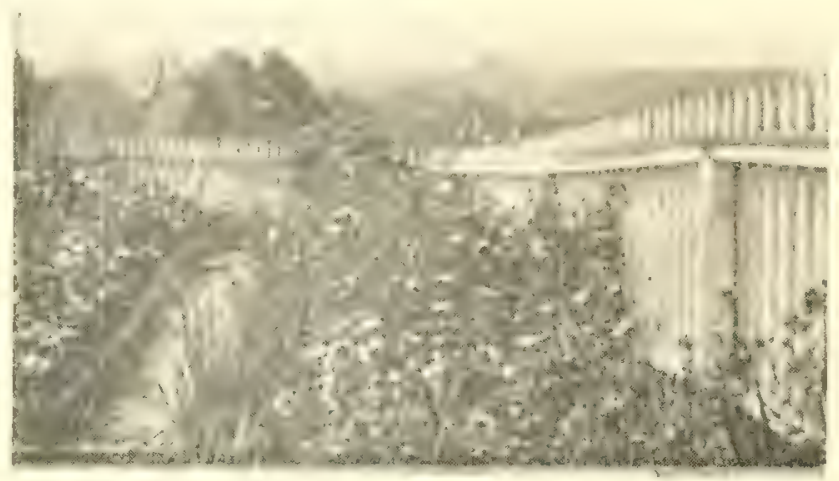

Asters grown as a IVinney Crop in a Penn, Garden. \$3.75 wo:th sold from this bed.

\section{Frances E. Nissley, Middleton, Pennsylvania.}

P. S. I almost forgot to tell you about the watermelons and cantaloupes. They were nice and big, and I weighed a watermelon that weighed eighteen pounds, and they were as sweet as honey. I got the seed from you. I had company and they said they never ate such melons.

\section{GOOD CROPS IN NEW MEXICO.}

From Brint Moody, Corrumpa, New Mexico.

We live away out in New Mexico on a 320-acre homestead. Our garden is excellent this year, and everything is fine except corn. It did no good at all. Watermelons were the best I ever ale. Mangle Wertzles were fine, very large. Beans, good. We had 31/2 acres and got iwelve hundred pounds. Beans pays best here on first years breaking. Our forage crops are immense. Only had fifteen acres. Got over 200 shocks of 20 bundles each. Everything is fine and dandy this year.

Brint Moody, Corrumpa, New Mexico.

\section{NOTHING BUT A BOY, EH-BUT THE RIGHT KIND.}

From Harry Cole, Hart, Michigan.

I am nothing but a fifteen year old boy. I have got a pretty fair garden what didn't wash out last spring. My melons, peanuts and popcorn are all fine. I have got a Halberi Honey watermelon that is twenty inches long. I picked a Princess watermelon today that was 30 inches in circumference, and it was about 12 or 13 inches long and weighed 18 lbs. They are a nice melon. My Halbert Honey watermelon or Hackensack muskmelons are not ripe yet.

\section{Harry Cole, Hart, Mich., R. R. No. 2, Box 69.}

\section{From E. McCulley, Arco, Idaho.}

\section{CAME FOR MILES TO SEE IT.}

This is an elevated region, about 5,000 feet above the sea level, and between degrees 43 and 44 north latitude. It was a bad season for my experiments, spring being the latest for years. It snowed in May and the frost killed the first transplanting of tomatoes. But June came in well and we put more plants and sowed seed in the open. About the seventh of July, some eastern friends came out to see us, and they did smile at what they termed our backward crops.

Then came the worst of it-I was not able to cultivale a thing. The seeds, however, were of such strength and vitality and gave the young plants such a start that the weeds could not down them, many persons saying they never before saw such heavy bean crops in any land. The season seemed rather short for the Lima beans, though we had some fine eating from them. Among the peas, the English Early beat the best in both quality and quantity, and funny to say, had two distinct crops from the same vines.

But when it came to the squashes, pumpkins and the melons, we had the show place of the valley. People came ten to fifteen miles just to see what could be done, but when 
they got a taste of the melons they were wild with delight. We had good ones of every variety, but the Princess watermelon and the Daisy Cantaloupe beat everything else out of sight. They were not the largest, but they matured such large numbers of delicious melons. At the approach of the frosty weather, every Princess, even though not more than four weeks from the bloom, matured. I never saw the like with any other melon. In quality they were better than the best of any other kind.

To farmers in irrigation districts, I may say, keep the water out of the hills or ridges, let it sub into them, and one good soaking in deep furrows is better than half a dozen hurried dashes of water. Flooding is not best for anything I have tried this year.

Give us Field's seeds for this great, irrigated Northwest.

E. McCulley, Arco, Idaho.

\section{ONIONS FROM SEED PAY BEST.}

From R. S. Mclean, Humboldt, Kansas.

Although this has been a bad year, we have done fairly well. I took fifteen premiums at

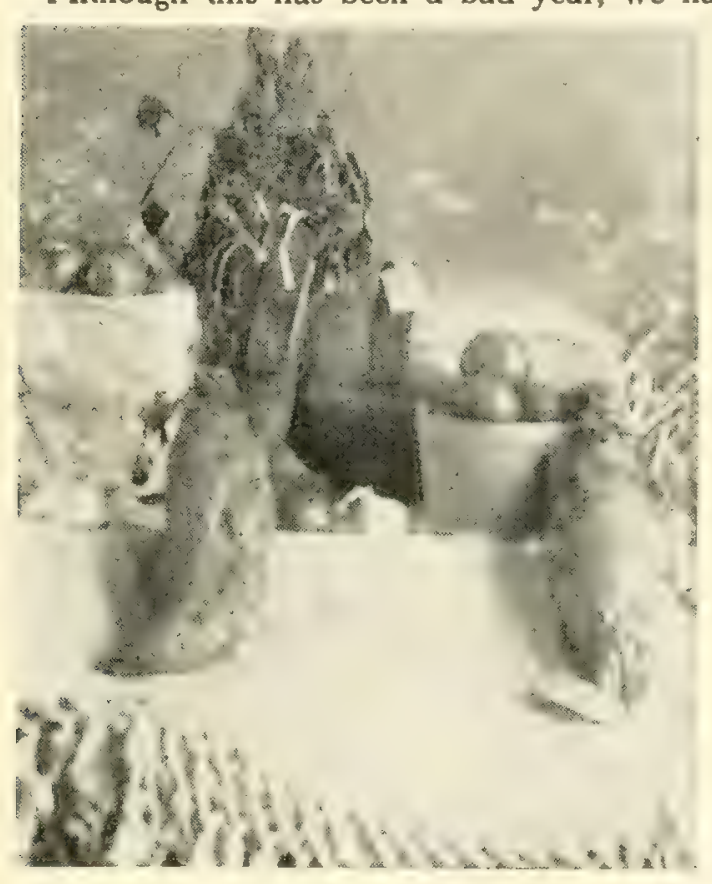

Prize Winning Vegetables in Kansas Iola County Fair. I was going to lake a wagon loaded with vegetables in the street parade at Humboldt, but was prevented by rain. I took three premiums there (all from your seeds). I have two acres in truck fenced with chicken wire.

Onions from seed pays best for the amount of ground. I raised twenty-five bushels on one-eighth acre, saleable onions, and plenty of small ones left. Those Prizetaker onions took the prize and sold for $\$ 1.80$ per bushel.

Oh, those Taft radishes beats everything. I took one to the exhibit that drew the attention of every one. I took premiums on beets and big squashes. In short we have lots of vegetables of every color and description.

The way to have a good garden is first good ground, or make it so, then good, pure seed and lots of work. Don't go off visiting and expect to have a big harvest.

\section{R. S. McLean, Humboldt, Kansas.}

\section{SOME GOOD SQUASHES.}

From Mrs. S. E. Cain, St. Annibel, Ohio, R. R. No, 1, Box 37.

I just had a small garden. Don't try to raise anything to sell, but raise plenty of vegetables of all kinds for a large family, but I sure raised some very fine squashes. From five vines, I raised thirty squashes, the largest ones. weighed about $20 \mathrm{lbs}$. apiece.

As for having pictures of squashes taken to send to you, I can't get them as there isn't any kodak around here. My largest head of cabbage weighed $15 \mathrm{lbs}$.

Mrs. S. E. Caln, St. Annibel, Ohio, R. R. No. 1, Box 37.

\section{DRY IN OKLAHOMA, TOO.}

From E. D. Johnson, Hobart, Oklahoma.

I will tell you the plain facts. I have been a customer for seven years, and the way I have been situated I could not test your seeds thoroughly. It has been too wet or too dry. This spring has been so $\mathrm{dry}$ and so many hot winds. Oklahoma has made a complete failure.

E. D. Johnson, Hobart, Oļlahoma. 


\section{\$9.28 WORTH OF PEAS FROM 3 PINTS OF SEED.}

From Mrs. Ed Trindel, Ralston, Wyoming, Lock Box 105.

One of the geologists employed to gather specimens of the New York museum, after having traveled the entire state, told us that we had muchthe best garden he had seen in the state.

My garden was a good advertisement for your seed house, as many were afraid your seeds were not suited to this country, but they changed their minds. "Seeing is believing," you know.

We live in the Big Horn Basin where the growing season is short. I planted one pint each of Alaska, Improved Extra Early and Fillbasket peas from which I furnished a family of seven with an abundance of fresh peas until frost, besides selling $\$ 9.28$ worth and dividing some with others.

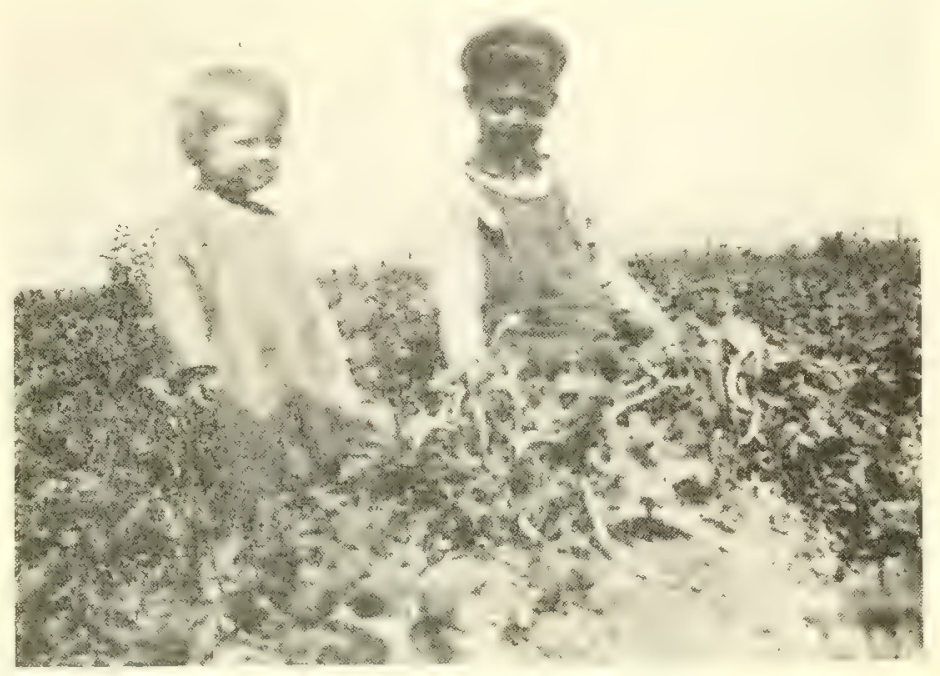

Wyoming Garden and Enthusiastic Young Gardeners. From two Pints of Beans sold $\$ 5$ worth and had lots left

I planted one pint of Field's first early beans and one pint of New Stringless Yellow Pod beans. I had the earliest beans in the country, selling $\$ 5.00$ worth, furnishing plenty for family use, and many going to waste for want of market.

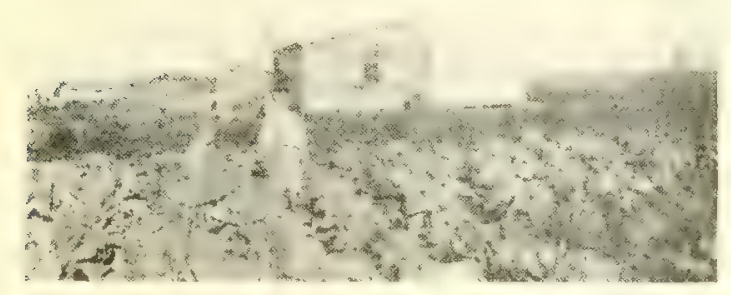

A Wroming Garden and Home

From two rows of beets, each 42 feet long, I pulled four bushels of fine table beets. From four rows of carrots, the same length, I pulled four and one-half bushels of extra fine carrots. I pulled and weighed specimens of turnips which weighed $101 / 2$ lbs., rutabagas weighing $81 / 2 \mathrm{lbs}$., and many specimens of my Early Jersey cabbages cleaned for table use weighing $61 / 2$ lbs. On one vine of Earliana tomatoes, I counted sixty-five well grown tomatoes without a blemish.

Also, I must mention our little patch of Senator strawberries. We ordered 100 plants as a trial, all of which reached us in beautiful condition and lived beyond our greatest expectans and we expect handsome returns from them next year.

Mrs. Ed Trindel, Ralston, Wyoming.

\section{EARLY GARDEN GOOD.}

From John Gash, Creston, Iowa.

I haven't any garden to write about or take snapshots of. My garden is all gone. The early garden did fine. I had onions, radishes and peas which did fine. Beans and cabbage burned up. Tomatoes are suffering for rain. I haven't anything worth taking a picture of. John Gash, Creston, lowa.

\section{SOME DAY - SURE.}

From Mrs, C. A. Sears, Waverly, Illinols.

Just now the garden looks like the southwest quarter of section seven of the Sahara desert and the water wagon not in sight. The flowers show up well, but the vegetables do not vegitate very fast.

Mrs. C. A. SeARs, Waverly, Illinois. 


\section{PLANTS MOSTLY SWEET CORN.}

From Mrs. Victor Hedman, Denison, lowa.

Owing to the dry weather I did not have a success with my peas. Had good success with Dwarf Champions. They stand dry weather better than English Champions and Marrowfats.

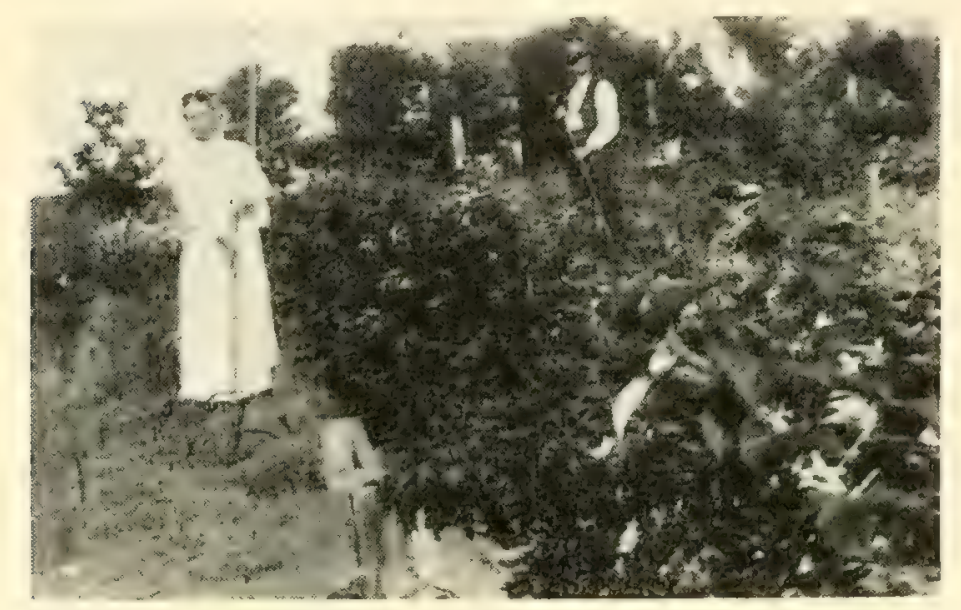

A Woman Market Gardener. She Rents 8 Lots and has 5 of her own.

My hobby is sweet corn. The Denison people said I have the best sweet corn. I have a fine trade on corn and good customers, so I can give up working by the day for others. The corn that stands dry weather is White Evergreen. The seeds I buy from Mr. Field all grow. The people said to me this summer, "How is it you had good corn when others had none." I told them that I bought my seed of Mr. Henry Field, and that I made a rule to buy new seed every year. The people plant old corn and they do not have success.

I rent eight lots and have five lots of my own all paid for. I plant mostly potatoes and sweet corn. The picture is the garden near the house. It shows the flowers and small products.

Mrs. Victor Hedman, Denison, lowa.

\section{OUR BEANS DO WELL IN GEORGIA.}

From Martha Campbell, Roswell, Georgia.

I had the finest beans you ever saw. Some of them were ten inches long and I sold a lot. I worked my garden every week until work was over. I live so far from town I could not have a photo made.

I had a nice garden when every one's garden was played out. I had a lot of flowers in my garden. You know how pretty morning glories are. I had a lot of them. I love a nice garden and flowers.

Martha Campbell, Roswell, Georgia.

\section{HE LIKES OUR GOODS.}

From Ferd Pauls, Leasburg, Missouri.

The drought has knocked me out of the contest. I am old and poor and may not be here next spring, so please take my name from your list. I like your seeds best of all. If I will need seeds next year, I shall let you know.

FERD PAuls, Leasburg, Missouri.

\section{PRINCESS A GOOD MELON.}

From H. H. Dowding, Jacksonville, Missouri.

We gardened nearly all over the farm, wherever we thought was the likeliest place. We had three varieties of watermelons including Princess. The Princess were good size, averaging four pounds each. The other kind were the finest specimens, one weighing $16 \mathrm{lbs}$. They were planted on bottom land and were not watered at all, and received ordinary cultivation.

H. H. Dowding, Jachsonville, Missouri. 


\section{SOLD \$144.78 FROM A GARDEN 100x150 FT., BESIDES FEEDING FAMILY}

\section{OF EIGHT.}

From J, D. WAdDle, Romney, W. V.

I want to tell you what I raised on less than half acre garden, it being 100x150 feet. The location of my garden is a southeastern exposure, soil, sandy loam, clay base well drained. Fall of 1910 turned under a heavy crop of Crimson clover. About Dec. 15ih coiered the ground well with stable manure, used disk harrow early in March, 1911, plowed deep with single shovel, harrowed, rolled and harrowed again. This gave me a perfect seed bed.

About the 20th of March I planted Irish Cobbler potatoes, set our Early Express Cabbage that had been wintered over in cold frame. At the same time, set out Grand Rapid Lettuce and Eclipse beets between the rows of cabbage. The beets were sown in cold frame first of February. I do not recommend planting between rows where one has plenty of ground. It is a very poor way to raise crops, especially if the soil is not rich with plant food. Then again it makes cultivation more difficult. I advocate everything of a kind planted in straight rows across the garden.

Smooth, medium sized potatoes were selected, cut half in two, and planted four inches deep. I prefer medium size tubers. I do not cut to one and two eyes because I think it highly essential to leave plenty of meat to furnish nutriment to the sprouts until they have taken root and can get food from the soil. The size of the seed piece is of much more importance than the number of eyes it contains. However, a piece should not conlain less than two eyes.

Planted Gradus and Thomas Laxton peas; it is hard to say which of the two I liked the best. Both are immense peas and as sweet as they can be. Planted Crimson Globe Radish, Hollow Crown parsnip, Giant Podded pole lima beans, Missouri Wonder pole Urim-- Daisy muskmelon, Princess Watermelon, Early White Spine cucumber, White Evergreen corn, - ase Giant pepper, Tobasco pepper, Black Beauty Egg plant. All of the above except the radishes, parsnips and corn were started in $4 \times 4$ paper boxes in hot-bed and cold frame. This was my first experience with the paper boxes, and I liked them so well that I will never try to garden again without them.

Set out three hundred Early June tomato plants that had been transplanted from hot-bed in paper boxes and put in cold frame until they were in bloom. These tomaloes commenced to ripen the last of June and every one was sold at ten cents per pound. I realized from the entire garden, after supplying the table for eight people, \$144.78. My fertilizer and manure cost me $\$ 15.00$, plowing and harrowing $\$ 3.00$. Labor (which 1 did all myself) at $\$ 1.50$ per day, I am satisfied did not cost more than $\$ 20.00$. This leaves me $\$ 100.00$ to the good. I intended to plant celery where I had early cabbage and potatoes, but was prevented from doing so by sickness. This would have netted me at least $\$ 40.00$ more. I am sending you a photo of a cluster of four tomatoes that weighed 50 ounces. My little 54 pound girl stands beside them. If I live to see another summer, I expect to make you a belter report, for I am going to tack on two acres in addition to my present garden.

The temptation is so great, I cannot close this report without saying a good word for Princess Watermelon and Improved Missouri Wonder Pole bean. The Princess has no equal from a view point of sweetness, and is the most productive melon I ever saw. The Missouri Wonder beans are the richest and most prolific I ever raised. I sold six bushels from 35 hills besides what we used.

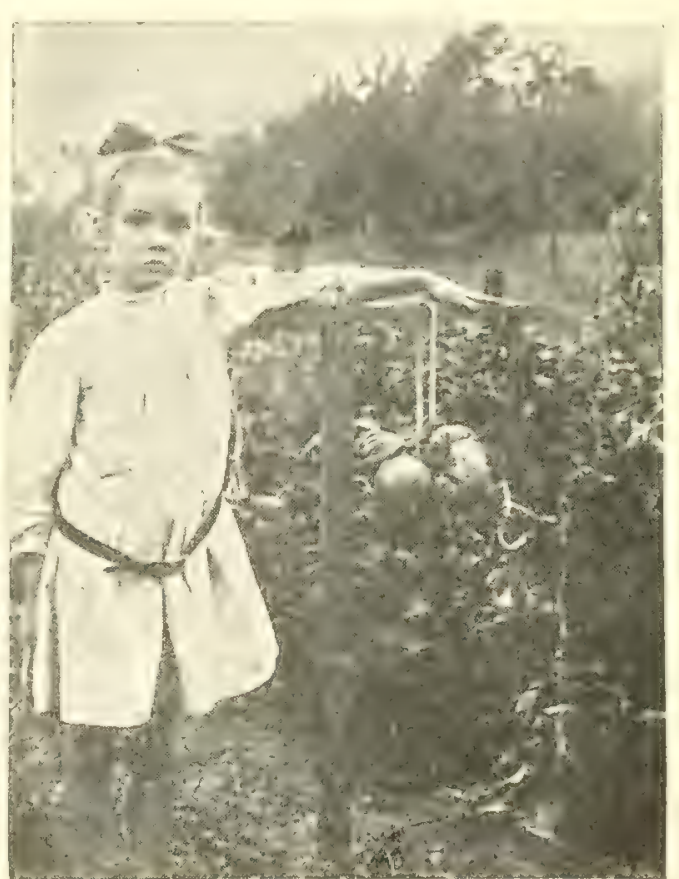

Four Tomatoes that weighed 54 Ounces, and a 54 Puund Girl all grown by J. D. Waddle. Rumney, W. Va.

J. D. WaddLE, Romney, $W . V$. 


\section{ONIONS PAID HIM BEST.}

From Martin Brooks, Centralia, W. Va.

Of my entire crop that paid me best, it was my onions, or which I enclose you a picture. My entire garden occupies one-third acre, or probably a little more, of which I planted about one-third in onions. I planted them last fall and they laid in the ground over winter and came up in the early spring. I put manure from the cow stable on them,

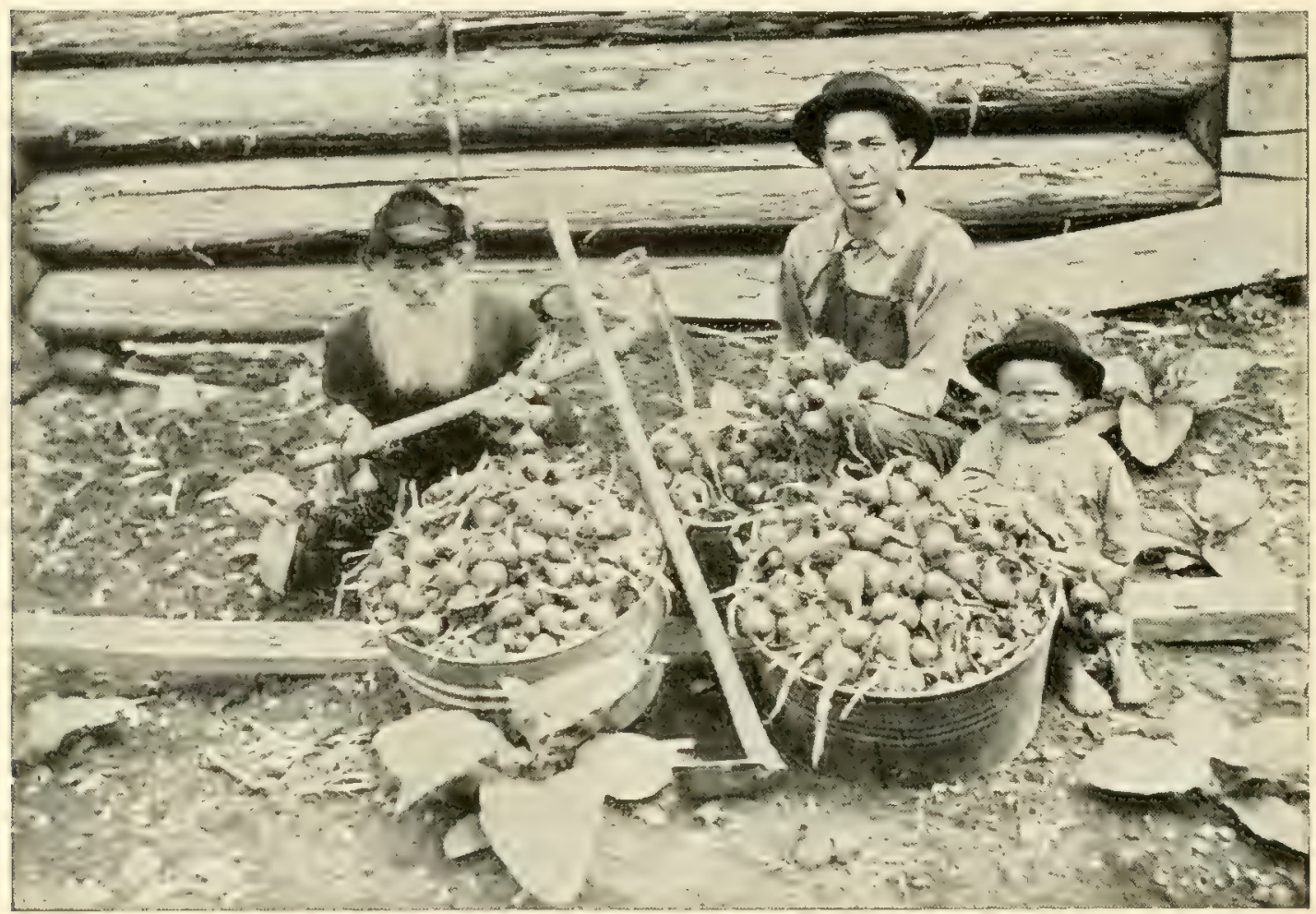

A Good Onion Crop and Three Generations of Good Gardeners

hoed them twice, and dug 12 bushels from the patch valued at $\$ 16.00$, and you know it didn't take no very small amount of labor to attend a piece of ground of this size. Then I ordered two ounces of Yellow Globe Danver onion seeds and sowed them thick in my cornfield fence corners and in open spots wherever I could find an open place, and raised from two ounces of seeds seven gallons of nice sets to plant next spring for big onions. My sets are worth $\$ 3.50$. I sowed the seeds in rows one foot apart and very thick in the row on the fifteenth day of April, and just pulled the biggest weeds out of them twice.

Then I planted six hills of muskmelons, your Netted Gem, on the first day of May. I dug a hole in the ground for each hill of melons about $21 / 2$ feet wide by $11 / 2$ feet deep, and mixed manure in with the dirt, about two-thirds dirt and one-third manure, till the hole was filled up level again. Then I planted my muskmelon seeds on top of the hill, hoed them three times, pulled the biggest weeds out once more, and on the fifteenth of August my melons were ripening, some of the best, sweetest ones I ever tasted. I have tried several seedmen to get the true strain of the Netted Gem muskmelon, but always failed until I tried you.

I always wait until the twentieth day of May to sow my late cabbage, and find it does much better and heads out nicer than what people sow earlier. I planted my cabbage in the open ground in hills on the twentieth day of May where I intended it to grow, hoed it three times, and had fine cabbage, although not a very large patch.

Planted eight hills of cucumbers on the first day of May to eat in green state, and twelve more hills on the fourth day of July to pickle. Did not manure them any, but all done well and I got some nice pickles from those planted on the fourth of July.

Planted some of your tomatoes on the first day of May in hills in the open ground, and beat all my neighbors for ripe tomatoes.

Martin Brooks, Centralia, W. Va. 


\section{A WOMAN FARMER WHO IS MAKING A BIG SUCCESS.}

From Allie Richardson, Baldwin, Kans.

My place is in a valley with a spring branch runining through it. The garden that I will tell you about is about five rods square. At the south side of the garden there is a strawberry patch about nine feet wide and two rods long, and I picked about ten gallons of berries from this patch. I plant my garden very close together and sometimes I get two or three crops on the same ground.

On the seventeenth of March I planted my early garden. First, a peck of bottom onion sets which produced about three bushels. There is a row of winter onions, which are very nice to have in the spring, and I make about three dollars a year on them. There was also a row of lettuce, radishes, beets, parsnips and turnips, and peas. The rows extend across the garden, and I had four rows of peas which averaged me about a dollar a row. I also planted a peck of early potatoes. This is the principal part of my early garden. I raise all my plants in a hot-bed, such as sweet potatoes, tomatoes, cabbage, celery, etc.

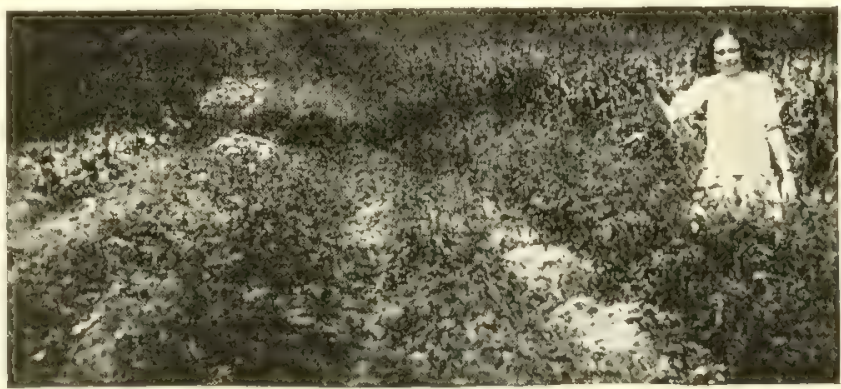

A Good Garden in Spite of Dry Weather. Good cultivation did it

The next planting was on the fifteenth of April. There was two rows of bunch beans of different kinds, for some do not come good when the ground is cold, and I planted them very thick so as to have some left when the cut worm has what he wants. Next was the cucumbers. I covered them so they would not get frost bit. Then I set my early cabbage, of which I have four rows, two rows of the small and two rows of the large heads. The small will be ready for use and can be pulled out, giving the large ones more room for growing. I plant lettuce and radishes about every three weeks all summer when I find a spot of ground vacant. I keep my ground well hoed and do not let a weed grow.

About the first of May I transplanted my tomatoes of all different kinds. I have two rows and the plants are set about three feet apart each way. The Early June is the earliesi tomato I know of. For sweet potatoes, I make my ridges about three feet apart. I set out about four hundred plants and they averaged about a bushel to every fifteen plants. I do not cut the vines off but pull them up and put them on the rows. I work everything at least once a week. If the ground is not worked and the weeds let grow, when you pull them they injure the plants.

Now, for the melons. About the last of May or the first of June I planted about thirty hills which were about three feet apart each way. I plowed them until they started to vine and then I hilled them up. I had fine melons and took first prize at the Fair. I planted

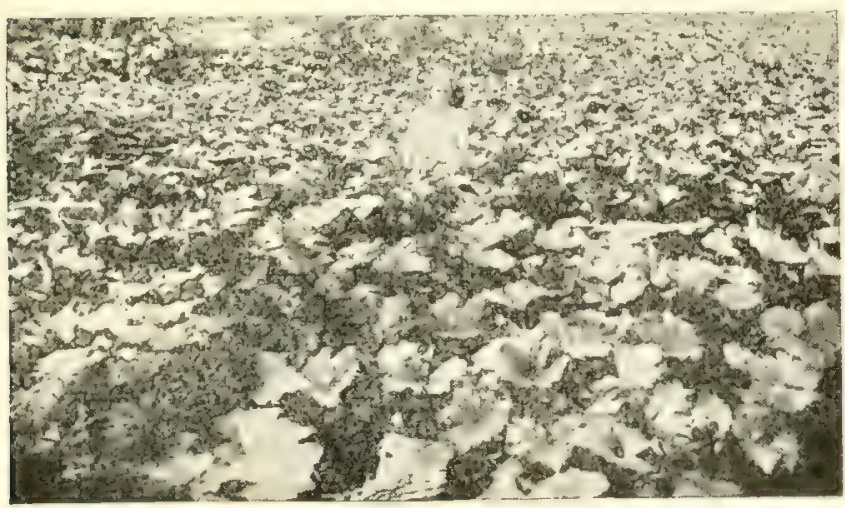

A Woman Farmer's Squash Patch. 70 Hills Made hundreds of squashes about seventy hills of squash and lended them about the same as the melons, and I raised them by the hundred. I took first prize at the Fair on them, also. I raised about fifty hills of pumpkins, principally for stock feed. They are so big no family wants to try them. These took second prize. There was five rows of popcorn in the corner of my garden, also some sage and parsley. From four rows of sweet corn, I had plenty for the table and three hundred ears to sell at $2 c$ each. My pole beans were planted where they could climb the fence.

I am a woman farmer who has been obliged to make a living for myself and three children. I have made my living for nine years now and have been engaged in farming nearly all of the time. This has been a very dry year. At times I was almost discouraged 
but I kept on working in my garden. People would say, "You are just working for nothing, it is not going to rain," but their crops failed while mine succeeded. My display at the fair consisted of forty-five varieties, and it took first prize.

Mrs. Allie Richardson, Baldwin, Kansas.

\section{A BOY'S GARDEN.}

From William J. Roudabush, Brooklyn, lowa. Age 14 years.

I am going to try to write you a few lines in regard to my garden. In it I had watermelons, muskmelons, stock beets, pie pumpkins, turnips, radishes, salsify, hominy corn, sweet corn and popcorn, all grown from seed bought of you. Then I had potatoes, the seed of which 1 got of a grocerman.

I planted most everything as your directions said. As I had only about a half a bushel

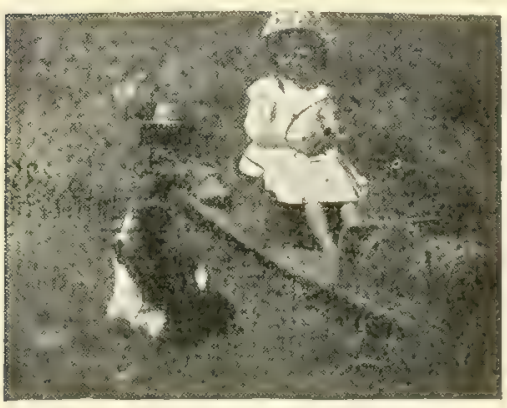

An Automobile Truck in a Boy's Garden of late seed potatoes, and was experimenting with them, I planted them about 26 inches apart. Everything grew fine except the salsify, which did not come up at all. I can honestly say that I have never tasted anything so good as those radishes.

I can't place a value on my stock beets at all, as I do not know what they sell for, and besides I raised them for my calf which I bought last spring. The beets cerlainly are fine ones. The pie pumpkins are fine large ones. I bought only one package of seeds of these and put all of them in only three hills, but they spread almost across the garden. You can see the pumpkin vines in the photograph.

I did not sell all of my garden stuff, but we used it, so that is just about the same. However, I will

Iry to make a calculation of the stuff that I raised.

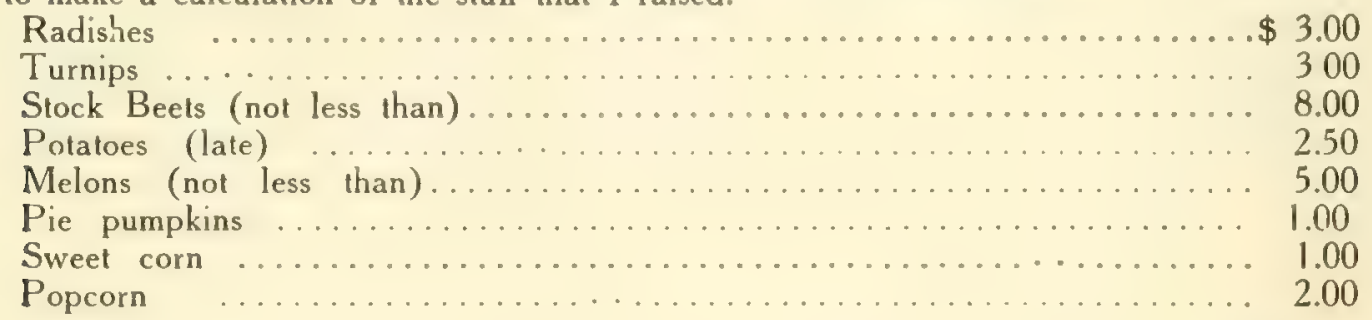

Total ................................ $\$ 25.50$

It did not take up much of my time to tend my garden, and besides I was sick almost all summer long. The photo is a picture of my little sister on my home-made automobile out in my garden.

William J. Roudabush, Brooklyn, lowa.

\section{HOT AND DRY IN WESTERN KANSAS.}

From Mrs. W. H. Finkle, Meade, Kansas.

Will tell you about my garden you requested me to report to you this fall, and how many vegetables I had. We had to contend with insects of all kinds, and Western Kansas certainly was hot and dry this year and a bad season for anything to grow. I am sure glad I bought my seeds of you, for I certainly did have a fine garden, all that could be expected.

I had a spot of ground in tomatoes $16 \times 75$ feet. They yielded an abundant crop, were of fine cuality, and I was much pleased with the results. I can't tell the number of bushels I raised. I had, also, an abundance of fine cabbage. Cucumbers did well. Had a fine crop of beets, and onions from the seed yielded good. Peppers did fine.

I am sending you a picture of some of the garden truck, and some in cans also. The baby in the picture is my grandson. We are sure proud of him. I am certainly pleased in every way with my garden. Mrs. W. H. Finkle, Meade, Kansas.

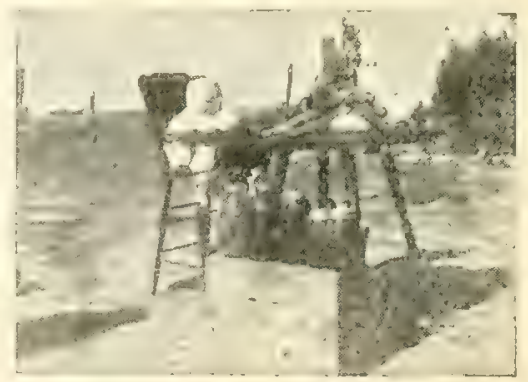

What One Woman Raised in "estern Kansas. A fine garden and a
mighty fine boy 


\section{2,183 TOMATOES FROM 64 VINES.}

From J. H. Freedline, Audubon, Iowa.

July 6, 1911.

My Dear Mr. Field: I am sending you a picture of the finest little field of Field's Early June tomatoes in the state, I believe. Just think of it, a little patch of ground twenty feet square with sixty-four of the nicest, thriftiest tonato vines on it that any one erer laid eyes on. On the first day of July I counted iwenty-seven tomatoes on one fine vine, and they are all fine, only some are a fow weeks earlier, having raised several dozen plants in boxes in the house. On one vine I counted Iwenty-seven tomatoes, most of them two inches in diameter, and just as smooth as an apple. I have a few of the celebrated Ponderosa in the same garden, but they are just beginning to bloom at present. Early June is about two weeks earlier than any I have ever raised, and I have had excellent gardens for the last ten years. On one vine there is a cluster of thirteen fine tomatoes that will ripen in the next two weeks. While they may be an unlucky number for one cluster, I should say it is a matter of good luck for every gardener

A number of people have come and seen this marvelous tomato patch, and they call it preacher's luck.

Aug. 24, 1911.

We had new tomatoes from "Early June" July $10 \mathrm{th}$, and have had them ever since. I keep picking them every other day and they keep right on coming. I am wondering what this tomato will do in a good season. I am keeping a record of the tomatoes grown and disposed of and it almost reads like magic. If any one in the state beats

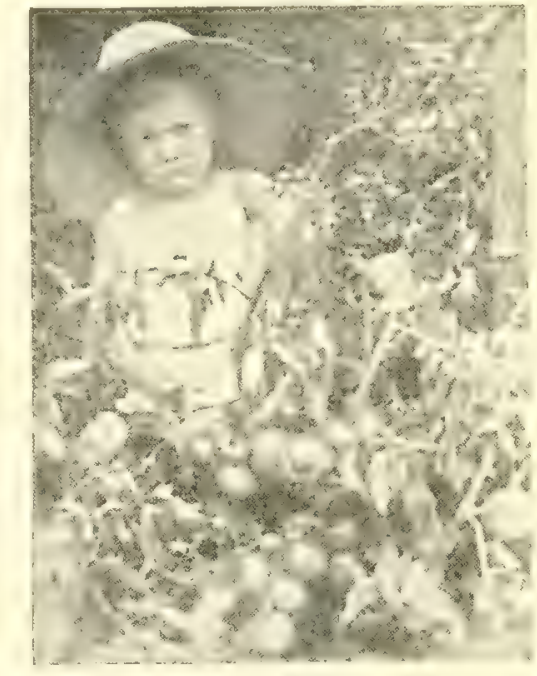

Without a Doubt the Finest Tomato in the World, and the Youngest Farmer in Iowa

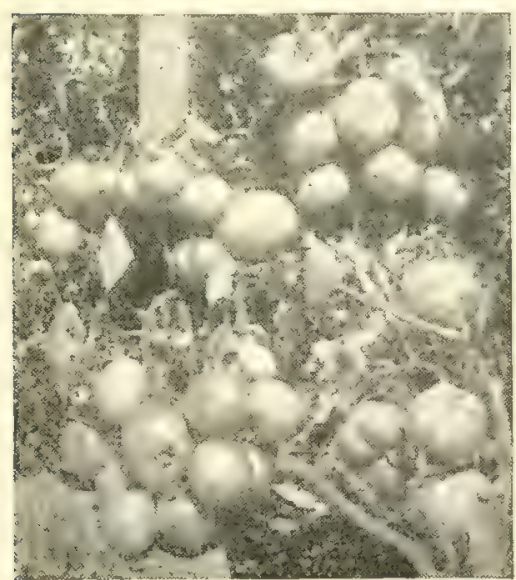

July 12, 1911, from Seed Planted April 1, 1911

this he will have to get a move on. I planted the seed in the open ground for most of my vines on April 4th, but about one dozen plants I started in the house a few weeks earlier.

\section{Oct. 28, 1911.}

Now that the frosts have come and put an end to my garden, I am ready to report to you. My sixty-four vines of lomatoes averaged thirty-four fine tomatoes to each vine, or a grand total of 2,183 , just a little better than 34 to the vine. If the frosts had not come they would have averaged 40 at least, as considerable half ripe tomatoes were found on the vines after the first frost. I cannot well put a value on them. We had new tomatoes when here in the markets they were getling 25 cents for three lbs. We sold some and gave many to our friends and neighbors. I like the Early June tomato the best for three principal reasons. First, they are the earliest, 2nd, they are the most prolific, 3rd, they are the most delicious for an early tomato.

\section{J. H. Freedline, Audubon, lowa.}

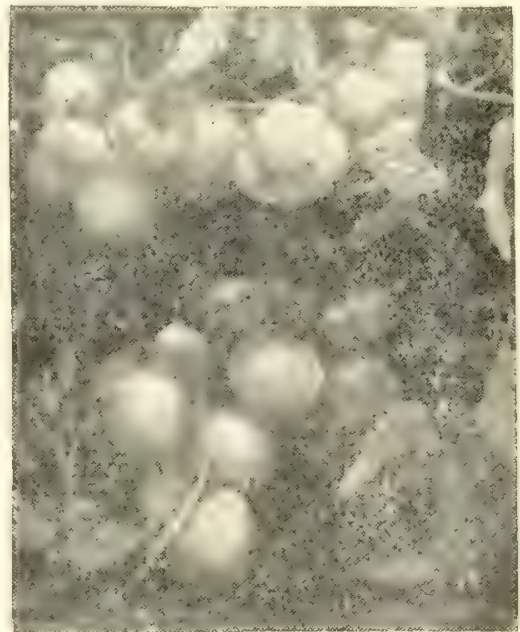

Another Sample of Field's Early June 18 Fine, Large Tomatoes in sight 


\section{CARROTS AND PUMPKINS PAID BEST BECAUSE HE TENDED THEM BEST.}

From John N. Witte, St. Cloud, Minnesota.

I suppose I will be one of the last ones in sending my letter, but the cause is that my friend that took the picture of my garden did not have the pictures ready to send it in. But now I have got them and want to let you know about my garden contest.

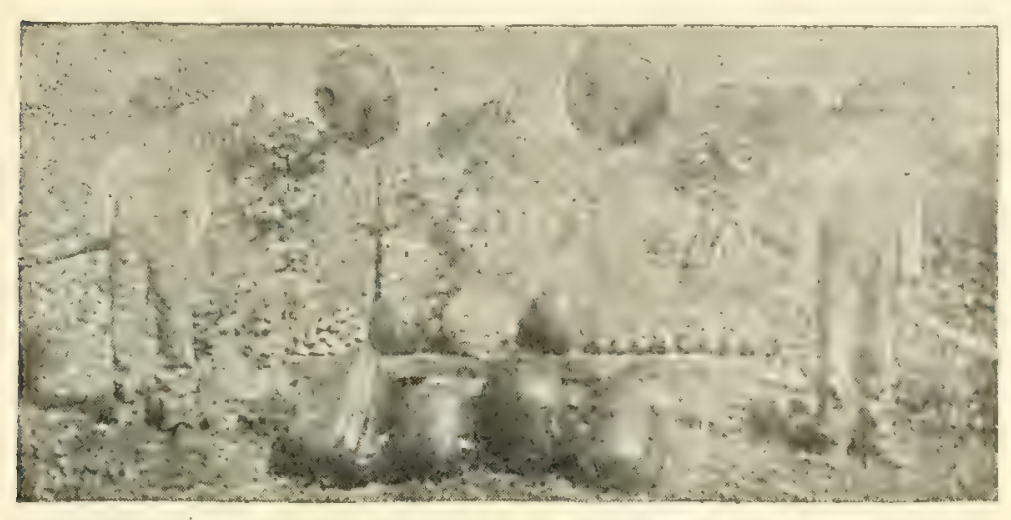

Two Minnesota Boys and Their Garden

I raised two rows of carrots, one row of onions, two rows of table beets, three rows of Mangles, and out of one package of watermelon seed, I received from fifty to sixty watermelons. Out of one package of cucumber seed, I picked from thirty to forty gallons. One package of pumpkin seed gave about a wagon box full of pumpkins. One of them we weighed, and it weighed forty-six pounds. These things I raised in the garden, and planted them just at the time when you told me to plant them.

My garden is about 120 feet long and 80 feet wide. In the middle of this garden there is a path about a foot wide, and one on each side also. When the things were small yet, I first hoed them carefully and picked out the grass, but then they grew taller I took the garden plow and cultivated them, so I kept

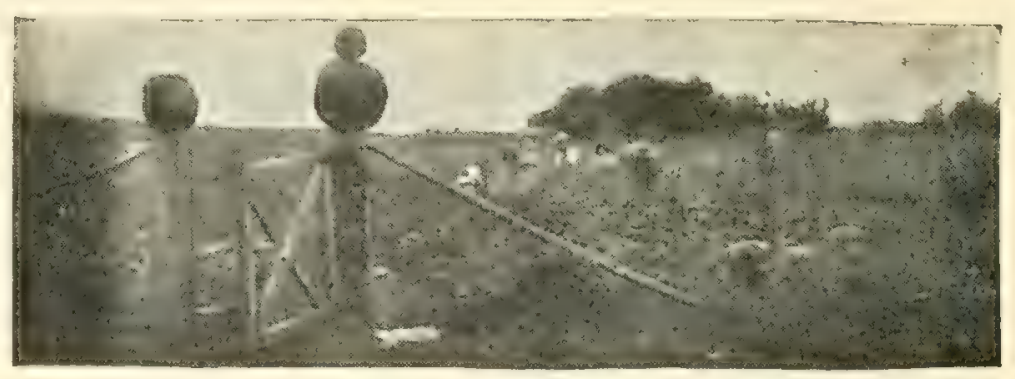

A Minnesota Garden them clean.

I think the carrots and pumpkins paid me best. I think the success of these two were because I tended them best.

John N. Witte, St. Cloud, Minnesola.

\section{TWO BUSHELS OF PEANUTS FROM 47 HILLS.}

From Mrs. Alice Casteel, Buffalo, Mo., R. No. 2, Box 58.

The dry weather nearly got me, garden and all. However, what is left is fine. I had 36 heads of cabbage to live, and they were large ones, too. I have 65 tomato plants, and I will put up 30 gallons if the frost does not come too soon. I had ten hills of cucumbers and have put up 12 gallons of pickles. They are still bearing. All of my early garden did well.

I cleaned my hen house every week and saved the manure for the garden. I hoed my garden over every week. My husband plowed the ground deep in the spring. After that, it was my work to keep it clean, and when the rains did come I had no weeds or crab grass to bother me.

I wish you could see my peanuts. I have 47 hills and I will make 2 bushels and probably more. I covered the blooms four times and I notice a few blooms now.

Give me a good sloping garden, plenty of chicken manure, a good hoe and rake and I will beat you all making garden-providing it is a favorable season. I got my seed from Henry Field, but I guess any kind of good seed would do.

My garden is $30 \times 80$ feet. I wish I could send you a picture of it, but there is no photographer any closer than ten miles.

Mrs. Alice Casteel, Buffalo, Mo., R. No. 2, Box 58. 


\section{THE BOOK OF A THOUSAND GARDENS}

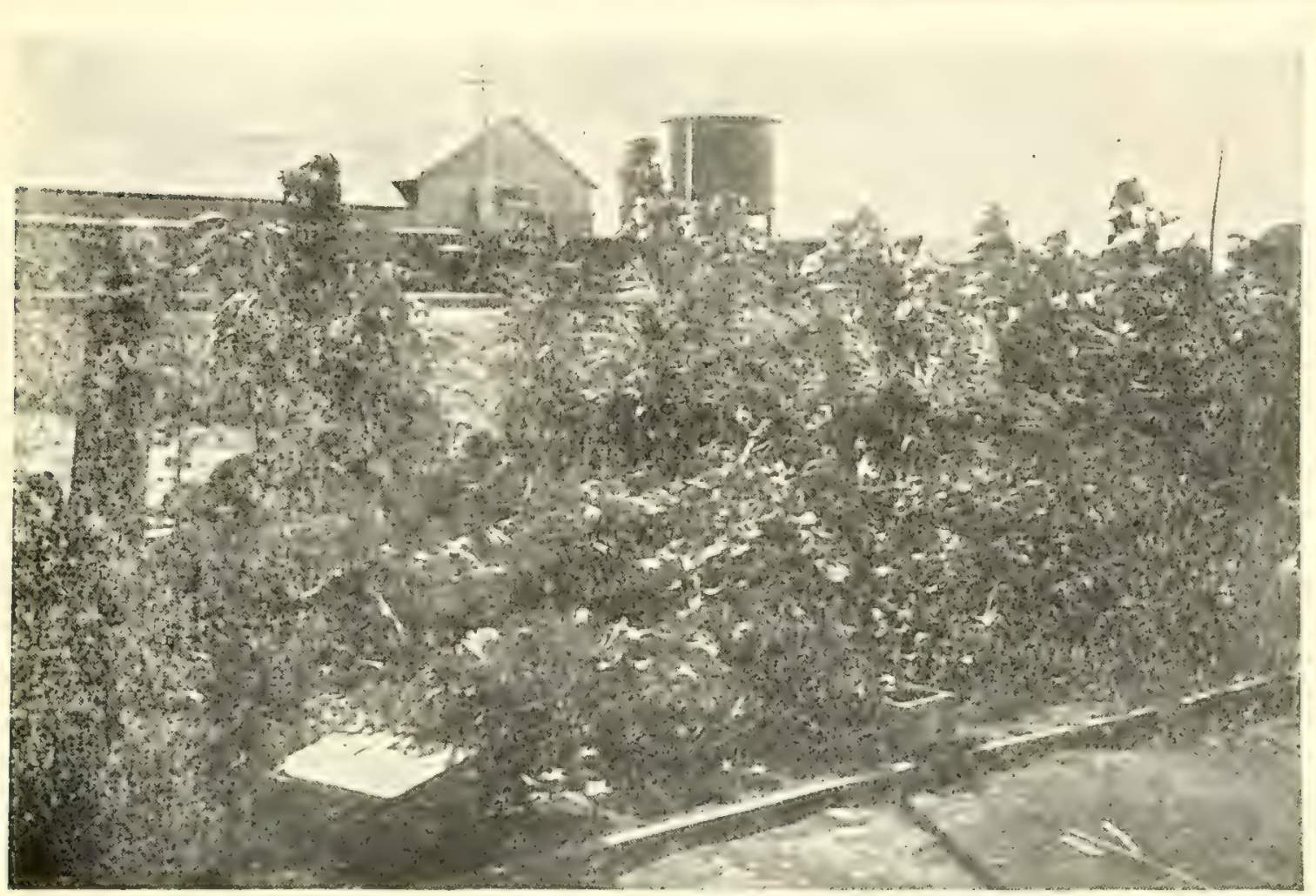

Corn, Cabbage, and Sunflowers along the U. P. R. R. in Wyoming

\section{GARDENING IN WYOMING.}

From Anna M. Hess, Ft. Steele, Wroming.

I am sending you under separate cover two pictures of my garden. The sunflowers were so tall they hid my other flowers and vegetables, but all I told you about are there, and also some sweet corn, as we had roasting ears several times. The picture of cabbage was taken back of the house and is close to the U. P.R. R. Just across the walk there are some sweet peas and other flowers and vegetables which would have made a nice picture, but $I$ did not have them taken. The vine over the window in the other picture is a wild cucumber.

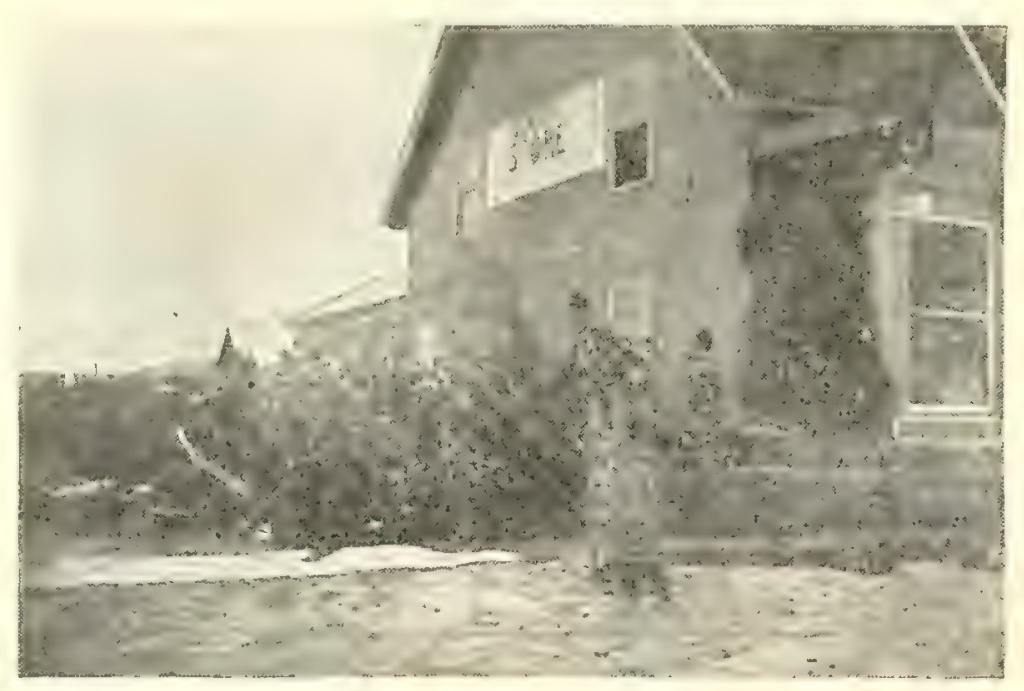

A Woman's Flower Garden in Wyoming

Anna M. Hess, Ft. Stecle, Wyoming.

TOMATOES AT THE RATE OF \$750.00 PER ACRE.

From E. A. Newell, Massillon, O.

We are sending you under another cover a picture of your tomato, Field's Early June, taken on or about July 8th. With us, they began to ripen the last days of June and we sampled them on July 4th. The seed was planted on Feb. 22nd, 1911, with other varieties. 
Well, the Early June came up first and stayed first. We planted out some 75 plants in a irial plot about May 15th, and we had quite a hard frost that night. I sprinkled them in the morning with the hose, but I looked for the blossoms to fall. Strange to say they did not. We kept count until the first of August, and there was $22 \frac{1}{2}$ to each stock, not counting what we used on the table. At the above rate, they would yield about $\$ 750.00$ per acre. I will send for some seed later.

E. A. Newell, Massillon, $O$.

\section{GARDEN BETTER THAN SHE EXPECTED.}

From Lottie S. Newman, Groton, South Dakota.

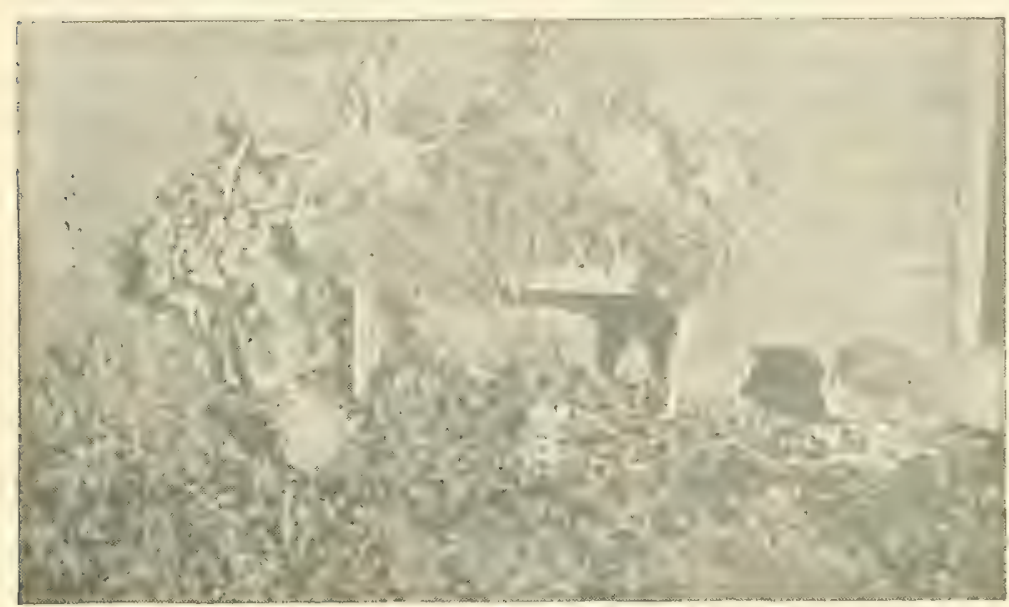

Good Vegetables from South Dakota
I am sending you two pictures of garden truck taken Oct. 22, and consists of cabbage, squash, corn, beets, rutabagas, endive, sweet peas and scarlet flax. The largest rulabagas weighed $81 / 4$ lbs., squash 16 lbs., cabbage 6 lbs. While I know that they could have weighed more, considering what I had to contend with, they are better than I expected.

Lottie S. Newman, Groton, South Dakola.

\section{LUCK DUE TO HARD WORK.}

From Frederik Fite, Parkton, Md.

I have a little less than a half acre of garden, but everything is fine. I had by the sixth of May my first peas, and have now, the fourth planting of peas up. I had my first sweet corn on the 7th of July, new potatoes by the 1st of July, and string beans on June 24 th, and cucumbers on the fifth of July.

We had very hot weather here and it was very dry, but now it is better. I am only renting the house and garden and work by the day, but every morning at five o'clock finds me in my garden, and all the people in the neighborhood say I have the best garden for miles around. I am unable to send any picture of my stuff I raised, for I don't have a kodak.

I shall, if I live until next year, get all of my seed from you. I am also sure that you will receive orders from my friends. They would have ordered yet this year, but it was too late. I also have a lot of flowers, and I tend to a private park here and the owner of it is very fond of flowers and shrubs.

I plowed my garden in February and planted my stuff early in March, as soon as the weather was fit. I have three rows of Sugar corn, four of peas, a bed of lettuce, 13 of potatoes, one and one-half of sweet potaloes, 2 of string beans, 2 of Lima, one of peanuts, and four large beds of flowers in front of my house, besides about a dozen boxes with flowers. There is also four rows of tomatoes, 2 of cabbage and one-half of beets, a few pepper plants, and a lot of radishes. You may think I haven't got all this on such a small garden, but I can give you proof of my honesty and my word.

I am selling a good deal of garden stuff. Corn brings $25 \mathrm{c}$ a dozen, peas $15 \mathrm{c}$ a quart, beans $10 \mathrm{c}$ a quart, potatoes $\$ 2.25$ per bushel, and lettuce two and three heads for $10 \mathrm{c}$.

All the luck I got is due to hard work. I haven't a weed in my garden.

Frederik Fite, Parllon, $M d$, 


\section{GALLONS OF CUCUMBERS FROM 27 HILLS.}

From Mrs. Wm. Hegglund, Gothenburg, Nebraska.

We had a big hail on September 9th which about ruined our garden, but I will send in a report anyway.

On April 9th I planted my tomatoes, cabbage, cauliflower, and peppers in a small hot-bed. "The weather was so cold that I didn't get to set anything in the garden iill about May 20th. Although it has been very dry and lots of hot winds, but by watering the things they all did fairly well.

My garden is 75 feet long and 35 feet wide. The gate is in the center of the south fence. The path runs straight across the garden from the gate, which divided the garden in the center. The west half was all in onions except one row of assorted flowers along the south fence west of the gate. Just north of the flowers was

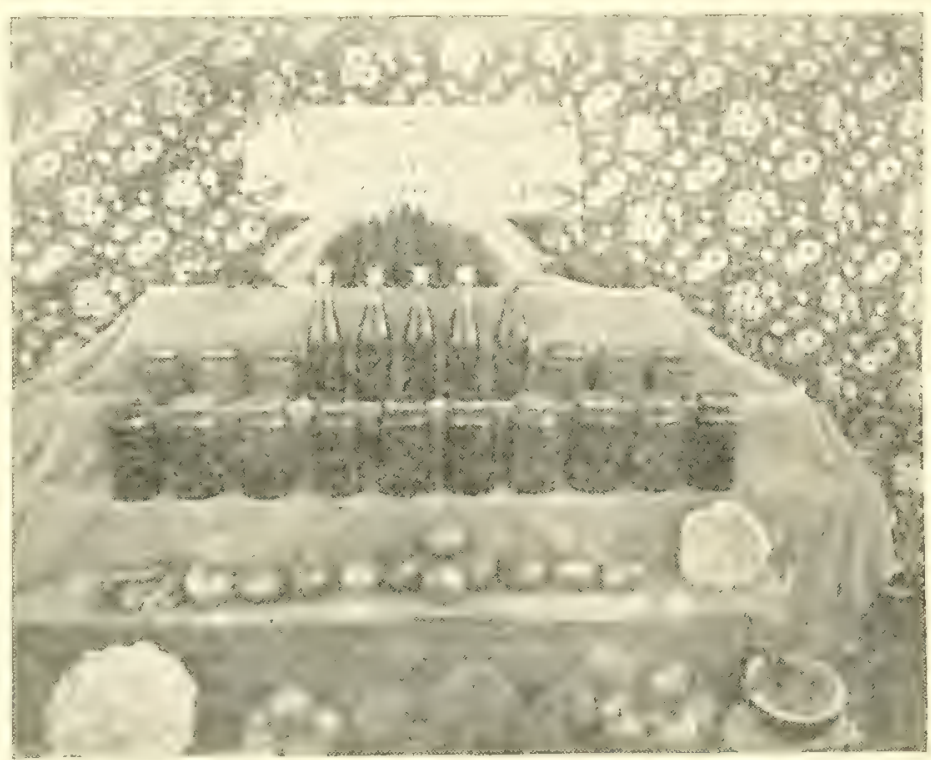

Looks like there would be plenty to eat this winter at this house

three rows of set onions. I planted three quarts and got $1 \frac{1}{2} / 2$ bushels. The rest of the garden west of the path was seed onions. I planted $11 / 2$ ounce of seed and got $41 / 2$ bushels. After the last of the set onions were used out, I planted 2 packets of onion seed for sets, but the hail pounded them to pieces, so I won't get any. The others were pounded pretty bad, but they healed over and seem to be coming out all right. I was short of room, so I planted my cucumbers among the onions. It worked all right until we had a sandstorm which broke the tops of the onions. I had 27 hills and got 39 gallons of cucumbers that would average from $2 \frac{1}{2}$ to 4 inches long.

In the east half of the garden I planted three rows of tomatoes along the north fence, ten plants to each row which made 30 hills. Next, I planted one row of cabbage and then one row of cauliflower. I got 22 cabbage heads from 23 hills which averaged 5 lbs. each. The largest one weighed $111 \frac{1}{2} \mathrm{lbs}$. Next to the cauliflower I planted one row of peppers, six hills of cayenne and eight hills of Ruby King. I got one gallon ripe cayenne peppers and three Ruby King peppers. They had just commenced to turn when we had the hail. The cayenne were also loaded with green ones. Next to the peppers I planted one row of peas, which yielded seven gallons, and next to the fence I planted four hills of the Little Princess watermelons. I got eleven ripe ones, and the rest were bursted by the hail. The largest one weighed $113 / 4$ lbs. They are the finest melons I ever saw, at least for this country. I planted three rows of beans between the rows of tomaloes and cabbage which yielded 47 gallons when I had to pull them out and let the tomatoes have the room. I left one row between the tomatoes and cabbage. I just cut the tops off and let them come out new. They had made nice tops and were in full bloom when the hail came, so I won't have any late beans. Between the rows of cauliflower and cabbage and between the cauliflower and peppers, I planted beets, but they didn't come so good, so I only got about a bushel. Between the peppers and peas, I planted a row of lettuce, but it didn't do much good, so we didn't have but four messes of it. I planted one-half packet of Chinese Rose Radish seed along the north fence and got one-half bushel to put down for winter use. When I planted my onion seed, I also dropped a few radish seed in the rows to mark them with so I'could commence to cultivate earlier. I used the little round kind. They did splendid and according to what the market is here there would have been over $\$ 10.00$ worth. I only got ten heads of cauliflower from 21 hills. They were as large as a pie plate. From the 30 hills, I got two bushels of ripe tomatoes, the rest went when we had the hail.

Mrs. Wm. Hegglund, Gothenburg, Nebraska. 


\section{LETTUCE AND RADISHES ALL SUMMER.}

From Harry Radlund, Kilbourn, Wisconsin.

On April 9th I planted some lelluce in the hot-bed. It was the first outside planting of the year. In seven days it was up. Later, I planted some at different times, so that we have had lettuce all summer.

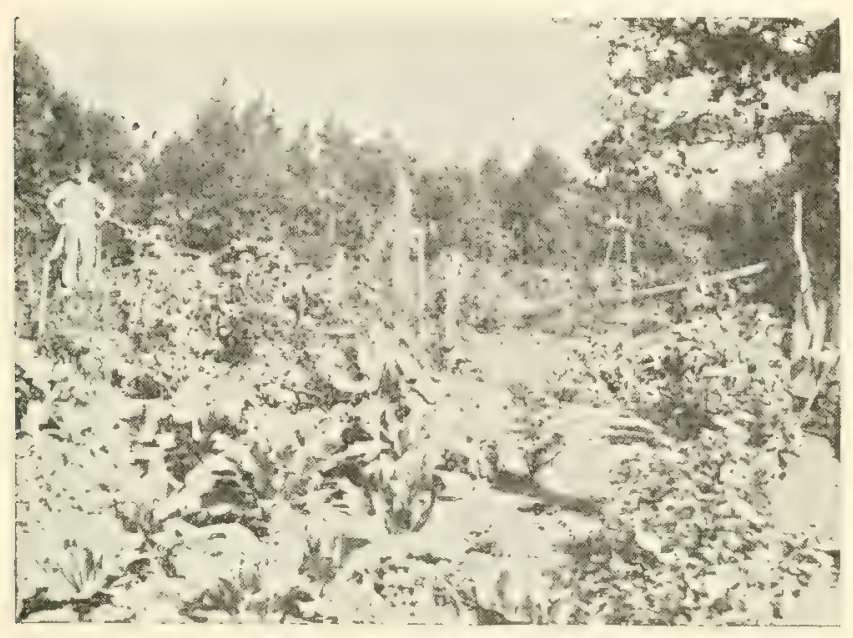

Garden of Harry Radlund, Kilbourn, Wis.

On April 23d, I planted some kale seed from you. We tried to raise kale for ten years but never had any success. This year, the best is about $31 / 2$ feet high and about three feet wide without spreading the leaves. On the same day I planted some dill, parsley, onion seed and onion sets. The dill grew good and went to seed, the parsley didn't grow very good. My early cabbage grew good and all the heads were used. The first planting of radishes was on April 25th, and I have had radishes all summer. The Shenandoah tomatoes in the garden are dandies, the best we ever had. So are the cucumbers. My cauliflower didn'i grow very well in the warm weather, but is growing fine now. Last spring I got Iwelve Udo plants from the Government. Eleven of them died but the last one is a good one.

I got a No. 6 Iron Age Wheel Hoe and seeder, a patented hoe, two common hoes, another hoe, and a home made narrow hoe. A straight tooth rake, a couple of bent tooth rakes, a trowel, an excelsior weeder, and some home made tools.

HaRry Radlund, Kilbourn, Wisconsin.

\section{THE GARDEN IS HALF HIS LIVING.}

From Walpole Nockolds, Loire, Tex.

I have about eight acres in my garden including orchard and berry patch. Mine is sandy land sloping to the south and east. I grew one-half acre of McGee, Globe, Dwarf Champion and Acme tomatoes, rows 6 feet apart, and plants four feet in rows. I never plowed them deep and had the finest tomatoes I ever raised till the drouth cut them short. I canned 26 gallons in molasses buckets and 300 3-lb. cans. I have two canners and consider them one of the most important and profitable things in a gardener's equipment. I sold $\$ 25.00$ worth of tomatoes, and we had all we wanted to use, which was quite an item as we are ten in the family, eight children, wife and self.

I had two acres black eyed peas. I sold $\$ 30.00$ worth of green, and $\$ 5.00$ worth of dry ones, besides saving seed enough to plant $31 / 2$ acres this fall, that are now blooming. I had one and one-half acres in watermelons in $12 \mathrm{ft}$. rows and $10 \mathrm{ft}$. rows, with a row of peas in the middle. I sold $\$ 102.00$ worth besides eating all we wanted and feeding the culls to my hogs. I cultivale often and shallow until vines get too long and then use the hoe.

My garden is half my living. I aim to have something growing the year round, but this year we had praclically six months drouth here, but have had a few showers and I have got some radishes and onions growing. This spring from January to April I sold $\$ 67.50$ worth of vegetables. This stuff was all planted in narrow rows and tended with wheel hoes. It was hauled 22 miles and sold on the San Antonio market.

I had two rows of Egg plants, not over 50 yards long, and off of these I sold $\$ 5.00$ worth and used all we wanted.

My garden is fenced rabbit and chicken tight with poultry netting and barb wire. I never allow weeds to grow in my garden and very seldom break any of it. As fast as one crop is off I plant another, thus keeping the land busy the year round. I do all the planting and most of the work myself, and I do it thoroughly, systematically and well. I get the best seeds possible from reliable seedsmen, buying no seed from country stores.

Walpole Nockolds, Loire, Tex. 


\section{1/2 PINTS OF PEANUTS FROM 10 HILLS.}

From Myrtle G. Miller, Minonk, Ills.

Our garden is scarcely more than one-fourth of an acre. The soil is very rich and we thought lo improve upon it by mixing the manure from the poultry house with the soil. You will see the result of it later on in this letter.

Every inch of the ground is marked into beds, spaded, hoed and raked until the soil is very fine. When completed, we have nice beds about six inches above the level of the ground. Only what ground we can get through with in one day is prepared, for when left it hardens and makes unnecessary work. We draw lines either across or lengthwise of the bed and sow the seeds in rows far enough apart to allow room for hoeing. We had thirteen kinds of vegetables and forty-three kinds of flowers.

Now, I will tell you what effect the manure had upon the vegetables and flowers. Radishes were larger, more tender, and matured quicker. Lettuce was very nice, some heads would not go in a gallon crock. Onions were not so large. Beans were more tender, but did not yield as many to a bush. Peas did not amount to anything. Beets and carrots were just grand. Tomatoes went to top but yielded a great amount of fine quality. Three of them weighed five pounds. I planted ten peanuts, and when I pulled them I had $81 / 2$ pints. They were cultivaled the same as polatoes.

Our garden is said to be the finest in the country. We expected a better result but the weather has been against us and our garden was planted in the last of May and the first of June. Our garden seems to us this year a sort of a failure, but other people think it is grand. We don't grow a garden only for home use and our own pleasure. What we don't use, we divide with the neighbors. We give our flowers to those that haven't any. The harder one works in the garden the better she will like the flowers; don't you think so?

Myrtle G. Miller, Minonk, $1 l l s$.

\section{"MOTHER RUNS THE GARDEN."}

From Mrs. Belle Chapman, Vermillion, South Dakota.

We had dry weather, cold, cut worms, cabbage worms, and all pests known and unknown. To say that I was discouraged but mildly expresses my feelings at the time. Of course I gave up the contest, but I thought I would tell you a few things about my garden, which turned out beller than most of my neighbors after all, as the blue lags that I took at the County Fair will testify. I took first on largest and best collection of vegetables, and first on popcorn, salsify, onions, beets, lima beans, dry beans, and second on slock beets; all from your seed.

I set out tomatoes the fifth time before I got a stand and cabbage the same. I planted onions expecting to raise a hun-

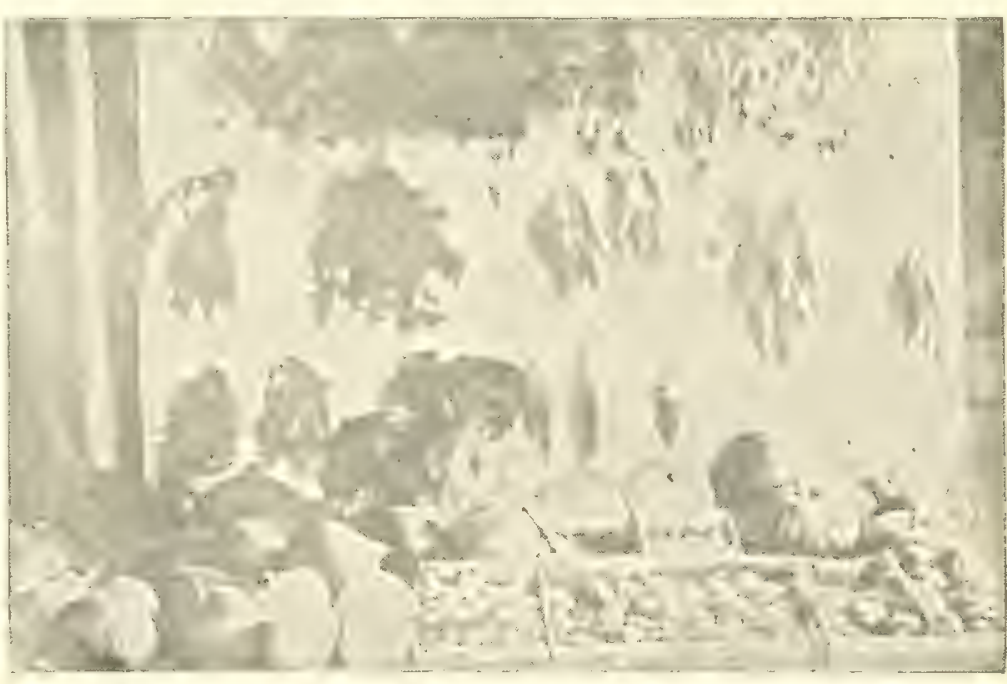

Display of Vegetables grown by Mrs. Belle Chapman, Vermillion, S. D.

dred bushels, but the dry, cold snow, and then a hot wind finished them. I only got seven bushels, but that is enough for our use. Had the ground plowed up and planted to polatoes which did fine. Planted parsnips and carrots three times, but did not get any. Planted beets three times and got about two bushels. Most other things did better, so that we sold quite a lot while green and have the cellar full for our own use. We are a large family, but mother runs the garden.

I had a poor garden, but if I had not had the best sced I would not have had any.

Mrs. Belle Chapman, Vermillion, S. D. 


\section{THE BOOK OF A THOUSAND GARDENS}

\section{SOLD \$73.72 FROM A SMALL GARDEN BESIDES ALL THEY USED AND GAVE AWAY.}

From Mrs. Frank E. Bauman, Barrington, Ills.

I live in the country $2 \frac{1}{2}$ miles from two towns where I have disposed of my garden vegetables. The size of my garden is about one-half acre, probably a trifle more. The soil is black loam well tiled.

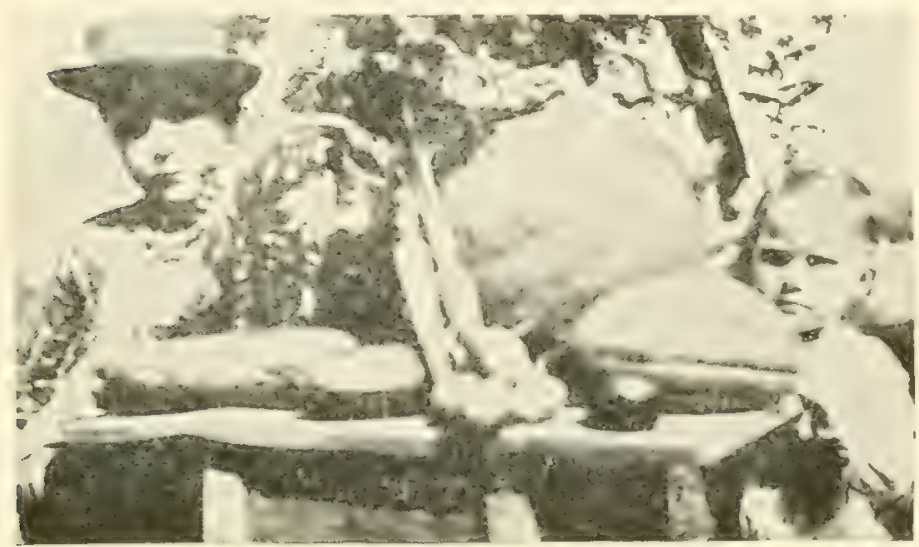

Raymond and Selma Bauman and some of the Garden they helped tend

I slarted my hot-bed April 1st, and put in it celery, beets, ground cherries, tomatoes, peppers, early cabbage, cauliflower, and sowed in the garden lettuce and radishes. April 12th I planted sweet corn, peas, beans, lettuce, spinach and flowers. Sowed late cabbage April 22nd. I set out beet plants when my neighbors did not have their garden plowed. April 24th I sowed radishes and main crop of beets, carrols, turnips, set out 10c worth of onions and sowed 20c of

onion seed. The 29th of April I planted beans, peas, spinach, and set out over one hundred early cabbage plants and three dozen caulitower. May 10th, I planted cucumbers, sweet corn, beans, peas, and set out tomato plants. On May 25th sowed beets, carrots, and planted a few peanuts that did very well. I planted some more beans, cucumbers, lettuce and set out tomato plants July 14 th.

I sold my first sweet corn the 3rd of July. During this time I was very careful how I sowed and planted in the light and dark of the moon. I was also very careful to sow and plant so one did not shade the other. I drilled all the beets and carrots about one foot apart, ground cherries and tomatoes three feet each way. Beans, I drop in hills nine inch in a row and nine inches apart and four in a hill. I started to hoe as soon as my plants were large enough and hoed deep all summer to keep the ground loose and moist. I had an awful time with cabbage worms and cucumber bugs, but found nothing better than slacked lime.

The following is what I sold:

Cabbage and tomato plants .................................. 17

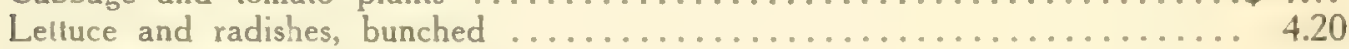

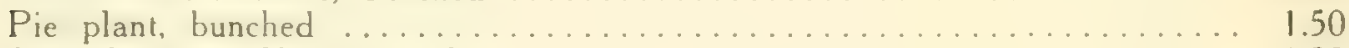

Spinach Swiss Chard, bunched ......................... 1.90

Carrots, Danvers Half Long .................................... 3.20

Beets, Eclipse, bunched ............................. 6.58

Peas, my own seed, at $7 \mathrm{c}$ per lb................................ 4.13

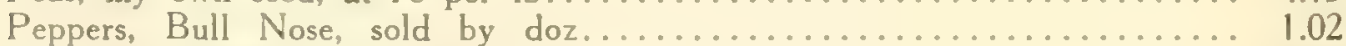

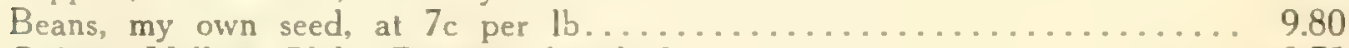

Onions, Yellow Globe Danvers, bunched ...................... 3.75

Turnip, Early Milan, bunched .......................... 1.15

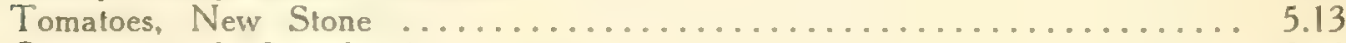

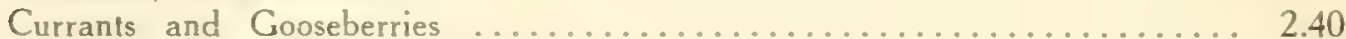

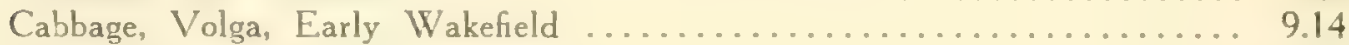

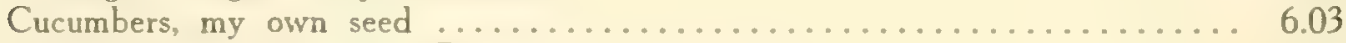

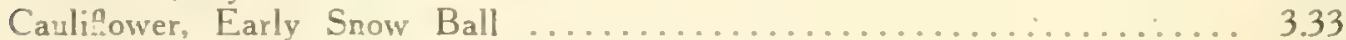

Sweet Con, Early Rose ............................... 5.59

Cround Cherry, my own seed ................................. 3.70

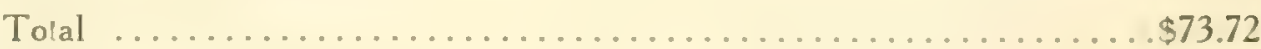

Besides this I gave a lot away and have in the cellar for my own use $31 / 2$ bushels beets, 
14 bushels carrots, which I intend to cut for my chickens; 11/2 bushels turnips, 60 head of cabbage, and made 18 gallons of saurkraut. I have at least six bushels of ground cherries, 3 gallons salted beans, 12 gallons of salted cucumbers.

Mrs. Frank E. Bauman, Barrington, lllinois.

\section{SICK AND HAD TO GIVE UP HIS GARDEN.}

\section{From Joseph B. Ordel,}

COLTON, S. D.

I am sorry to say I can't enter your Garden Contest, because I have been in bed at Sioux Falls hospital and had an operation, so I could not take care of my garden and it has all died out and is all gone.

Every seed came up fine, but I was not able to tend to it so it is not the seeds' fault, it is my fault as 1 am not able to do anything yet. If I don't get any better, I will have to leave the country.

Joseph B. Ordel, Collon, S. D.

\section{THE CRAYON PENCIL DRAWINGS WERE ALL RIGHT BUT THEY DID NOT REPRODUCE WELL.}

From H. O. Helgeson, Colfax, Wis.

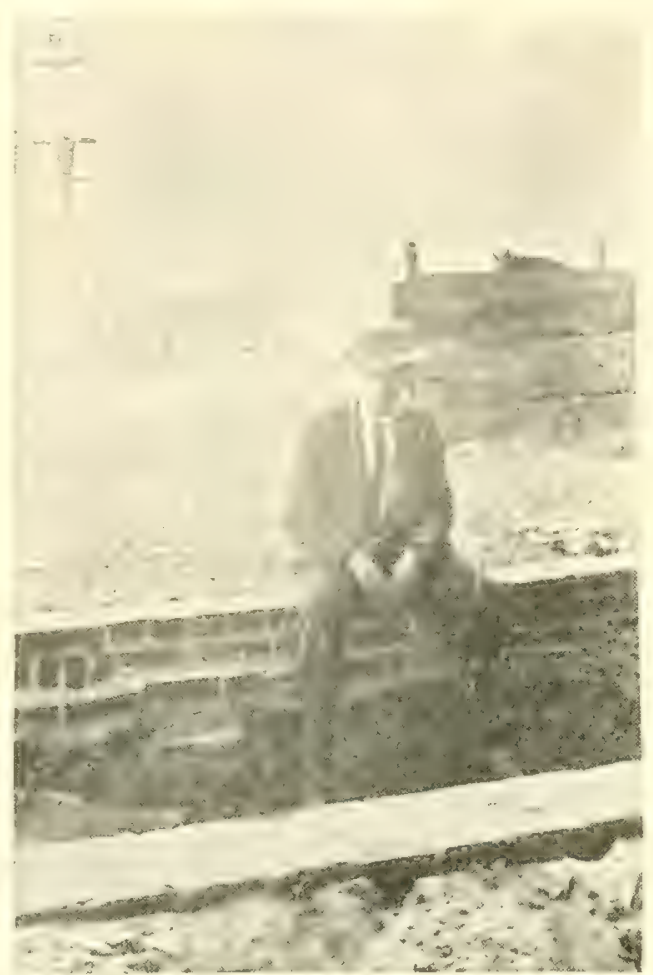

The Boy who had to go to the Hospital and could not tend his Garden

I have reced a Good Crop of Garden dis year my Garden was 100 Feet Squor aroun. i Ploud my Garden Good before i started too Plant it, and den i Put Som Menur on it. Cabes I raced a Good Crop too i Sold tem at 50c Bushal, i had oney 10 bushol of dem dis yeer, and $i$ had Som Carot too and $i$ Cot 10 Bushol of dem dis your Sold at $45 \mathrm{c}$ Bushol and I Raced som Tomatoes i Raced 15 Bushol thay was wort 45c Bushol and Flours was pudy Faer too.

I will Kindle ask you for won Ting, if it Will be oll rit to drow my Pictures of Gorden wit comen Grayons Pencil I have ask my Friends for won picture codack but day hav not enney too boro too me, so der for i Will drop you a fuw Lines abut dis Let me Now by retrunt Mail if dis will be all rit or not.

H. O. Helgeson, Colfax, Wis., R. R. 5, Box 63.

\section{GARDEN ALL IN LONG ROWS.}

From Mrs. Blanche Neal, Moorhead, lowa.

Our garden plot of little more than one-third acre of blue grass sod was disked iwice, plowed, disked iwice more, then harrowed and fenced. An early garden of radishes, lettuce, peas, beans and onions was put in the second week of April. The rest of t':e cabbage and tomato plants and peanuts was put in about May 10th.

The whole garden was put in straight rows and worked with a team and cultivator. It was all cultivated twice and parts of if three or four limes. After the plants and vines were spread so the team and cultivator could not be used, we went over it all twice, pulling the weeds by hand and fed them to the hogs. This kept the garden clean and the ground loose, so that very little hoeing was done by hand.

By the fourth of July we had ripe tomatoes, cabbage and sweet corn to use. We picked the first ripe watermelon the 19th of July. All of our seeds came from the Henry Field Seed Company, except part of them we saved ourselves from last year's garden. 


\section{THE BOOK OF A THOUSAND GARDENS}

Tomato plants were set in between the early radishes and lettuce and late turnips and beans sowed where the early peas and beans were.

We had plenty of vegetables for our own use, gave a good deal away and sold a total of \$44.27. We dug two bushels of sweet potatoes (had almost half used before digging time), $11 / 2$ bushels of peanuts and $11 / 4$ bushels of beets to put away. So we feel well paid for the work spent on our garden.

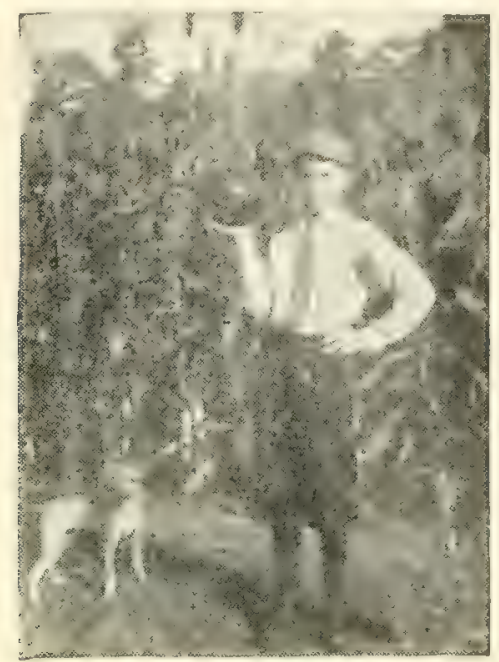

A Fine Princess Melon

Mrs, Blanche Neal, Moorhead, Iowa.

\section{PRINCESS MELONS FROM 6 HILLS.}

From Henry Love, Union City, Mich.

Here is my report and the picture of a "Princess" melon I raised from those few seeds you sent me. In the picture you can see my fine stand of Kalfir corn. It was fine, but my cow peas behind it beat all. I am planning to send early for seed next spring.

It was June 3rd before I got a seed into the ground. From six hills of Princess melons 1 had 24 luscious ones, each fit to set before a king.

I would have sent in my report earlier, but we moved and the catalog got misplaced. I did so want to earn a prize, for my papa is not able to work and my mama has to work out to keep me in school.

Henry Love, Union City, Mich.

\section{HAD SOME SPLENDID SWEET CORN}

From Mrs. Annie McEmber, Pentwater, Michigan.

I will try to tell you about my garden I raised, but as I wrote you before, this past season has been the extreme of hot, cold, dry and wet. But here is what I sold: Ten bushels of tomatoes at $\$ 1.00$ per bushel, 10 bushels 75 c per bushel, 15 bushels $50 \mathrm{c}$, total for tomatoes $\$ 25.00$. String beans $\$ 11.00$, ten hundred ears sweet corn at $\$ 1.00$ per hundred, $\$ 10.00$. One hundred heads cauliflower, 50 at $10 \mathrm{c}$ each and 50 at 12c each, $\$ 11.00 ; 5$ bushels beets 35 c per bushel, $\$ 1.75 ; 5$ bushels carrots, 35 c per bushel, $\$ 1.75 ; 50$ bushels Early Po!atoes at $85 \mathrm{c}$ per bushel. Fifteen crates strawberries which sold for $85 \mathrm{c}$ per crate, and besides we used lots of fresh berries and canned up for winter use, and it is not any small amount of fresh or canned fruit or vegetables either that we use in our family of eight. We have used quantities of green stuff such as every good garden ought to contain which I haven't given account of yet. String beans and shelled beans for fall and winter use, Lima beans, beets, carrots, onions, both green and dry; parsnips, cauliflower, cabbage, turnips, radishes, lettuce, peas, asparagus, celery, cucumbers, popcorn, pie plant, peppers, squashes, pumpkins, watermelons and muskmelons. Besides I have one row each of currants, gooseberries and seven varieties of fine 10-year old grape vines. Say, we had all the nice sweet potatoes we have needed for use, also husk tomatoes and purple plum tomatoes.

This report has been unavoidably 'delayed, but I will just send it along so you can see what one farmer's wife, who has been in poor health is trying to do. My husband isn't the least in love with any kind of garden work. All the help I get is now and then one of the children help an hour or so and two or three times during the season. All vines, plants and bushes that stay green year after year are set in one side of the garden plot in rows so as to not be trampled on, in the spring when the ground is plowed, then everything is set or planied in rows running the same way. Where there is only a few short rows of any kind, I continue the rows the full length of the garden with some other kind of vegetable. My husband says there would be about $11 / 2$ acres of ground in my truck patch if it was altogether.

Taking all in all I think I received the most ready cash with the least expense for my crop of sweet corn, as nearly every stalk had two good ears on it. Then the fodder is selling for $31 / 2$ to $4 \mathrm{c}$ per bundle, which means another profit of $\$ 1.50$ or more. The tomatoes brought more but cost much more for the care spent on them and more ground.

Mrs. Annie McEmber, Pentwater, Michigan. 


\section{TENDS THE GARDEN WITH A TEAM.}

From Jacob Servis, Logan, lowa.

I thought I would write you about my dry weather garden. It looks well considering the dry weather. I had a dozen pictures taken and will send you some.

I have about an acre in my garden, and I am in the mushroom business too, and eighty acres of land to see to. So you can see I have something to do.

Now as far as tending the garden, you will see in the picture that everything is in rows three feet apart. I plow everything big and little with the garden plow about three times and three times with the cultivator, and hoe it about three or four times if needed.

\section{JAcob Servis, Logan, Iona.}

\section{A NICE GARDEN ACCORDING TO THE SEASON.}

From Mrs. Jennie NisWonger.

Mr. Field, I will tell you about my garden, which is 100 feet long and 54 feet wide I sowed the celery, cabbage and beets the middle of April. I had good plants of them, and I sold quite a few of them. I had a nice small patch of cucumbers that bear well. My cabbage is heading nice, too. I have five rows of sweet potatoes and five of Irish potatoes. I set the celery in beiween the sweet potato ridges. I set beets around the peas and the tomatoes along the fence.

I had a small patch of early Ohio potatoes that was good. I then planted sweet corn between the rows, and between the late potatoes I set late cabbage.

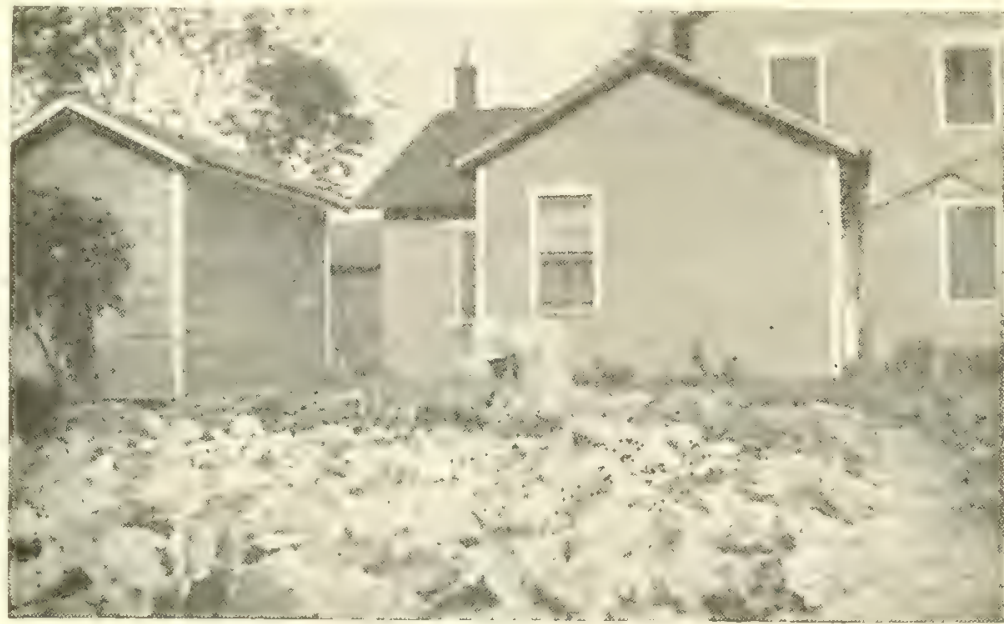

Some Fine Cabbage and Beans

I watered the flowers and garden every morning and evening with the hose. I will try to get a picture of some of the vegetables and send it later. I have a nice garden according to the season.

Mrs. Jennie Niswonger.

\section{PROUD OF FIELD'S EARLY JUNE TOMATO}

From Edward G. Knapp, Oswego, New York.

You will find enclosed a photograph of my Field's Early June tomato which I am very proud of. I got from $25 \mathrm{c}$ to $30 \mathrm{c}$ a bushel more than I did for any other kind. People that has had them once wants them again. I had customers tell me that they will keep nice and hard for a week, where others get soft the next day. Now this picture, as you will see, is pretty well loaded down. I tried to hold it up by the roots when I had it taken, but I could not, as it was too heavy. There was more than fifty tomatoes on it.

The way I plant my tomatoes is by plowing and harrowing the ground good, then mark it four feet both ways. Then I furrow it out one way, putting some manure in the hill and some dirt over it, then I place the plants on the cross mark and cover quite deep. As soon as the plants straighten up, I cultivate them both ways until they get too big, then I stop. As to how much I made, I can't tell you yet, as I am still picking them every other day. Will tell you later.

E. G. Knapp, Oswego, Nen York. 


\section{LETTUCE THE MOST PROFITABLE.}

From Lottie E. Newman. Groton, S. D.

My garden is 6 rods and 9 feet each way and contains the following vegetables and vines: 14 rows of cabbage, 16 of rutabagas, 8 of onions, 1 of lettuce, 1 of endive, 2 of

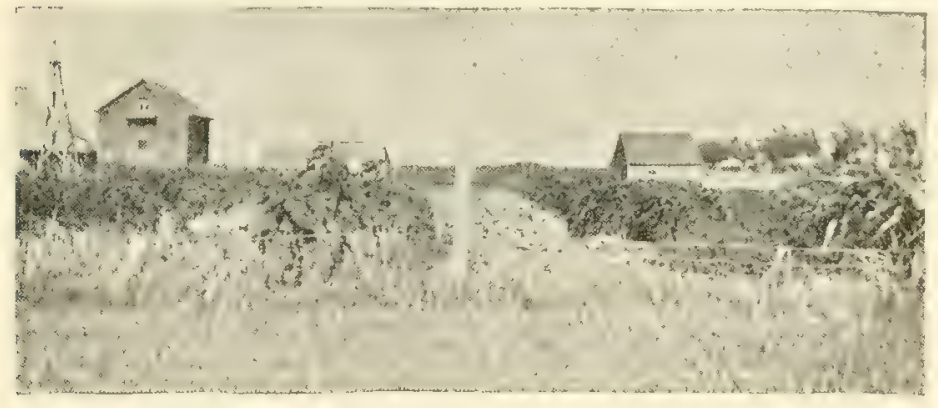

A Good Garden in South Dakota in spite of Dry Weather carrots, 2 short rows of beets, 1 of peas; had two of radishes, but have eaten them up long ago; 12 rows of popcorn, four outside of garden fence; 80 hills of sweet corn, 6 hills of Field's sample corn, which can be seen in back ground. Will say here that every kernel grew, as I counled them before planting. 136 plants of tomatoes, 17 hills of watermelons, 12 of muskmelons,

14 of Hubbard Squash, 45 of cucumbers. Then, I also have a few flowers, which are now in blossom, which consist of 3 short rows of sweet peas, 3 of nasturtiums, 2 of poppies, I of sunflower, I of scarlet flax.

This has been a dry summer. There is no grain crops at all in this locality, but the corn looks good. I am sure I don't see how the garden lived and looks as well as it does. These pictures were taken July 16th. The garden was planted in an old hog yard which was sown to some kind of grain every summer. It was well plowed and then harrowed until nice and smooth, then all of the seeds were put in with the garden drill far enough apart so they could be cultivated with a hand cultivator. Then, I have used the hoe a good deal, in fact I hoed and cultivated almost constantly during the very hot weather.

1 have so far found lettuce the most profitable; as I have sold $\$ 3.00$ worth to a hotel. The lettuce was sown between two rows of corn and it grew nice and tender, and was much better than lettuce sown by itself. This week, I am to take some rutabagas to the same hotel. If the dry weather hadn't interfered, I would have had a garden to have been proud of.

The army worms put in their appearance soon after the pictures were taken and have eaten off all the onion tops, then went after the cabbage and rutabagas. The tomatoes are not hurt at all. They came so thick and fast and worked so quick there wasn't much use trying to fight them, although I did put Paris Green on part of the garden.

Lottie E. Newman, Grolon, S. Dak.

\section{ENOUGH MELONS FOR A FAMILY OF 6 FROM TWO HILLS OF PRINCESS.}

From J. M. Plummer, 340 Orient Way RUTHERFORD, N. Y.

I enclose a photo of Princess Watermelon. We had two hills only, but had a large number of melons, enough for our family of six and some to spare. We think the flavor excellent, and the half watermelon looks so pretty on the table, one-half to a person. It is a decoration as well as a dessert.

\section{J. M. Plummer,}

340 Orient Way, Rutherford, N. Y.

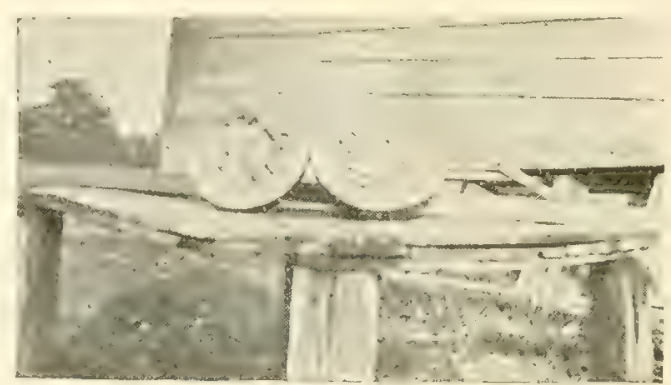

Princess Melons

\section{DRY WEATHER GOT HIM.}

From H. H. Dowding, JaCksonville, Mo.

Owing to the continuous drouth that prevailed here, I have very little to say of my garden crops. Most garden truck failed to produce anything at ail. I had one Princess watermelon that weighed four pounds, and it was fine. The free packet of Japanese Beans produced a full crop in spite of the drouth. They are not quite ripe yet.

H. H. Dowding, Jacksonville, Mo. 


\section{LOTS OF STUFF FROM A SMALL GARDEN.}

From Jas. Koser, Аbbott, Colo.

I have wished lots of times for a good garden with lots of truck in it. This year, I have it, and this is the way I got it. First I got four seed calalogs, and out of the four I picked Henry Field's seed catalog and bought a few dollars' worth of seed of different kinds. After all danger of frost was over, I put in my garden, the last week in May, onions and potatoes much earlier.

I laid off ground for the different kinds of seed I wanted to plant and put them in, and they all came up quick. I kept it all well hoed and free from weeds,

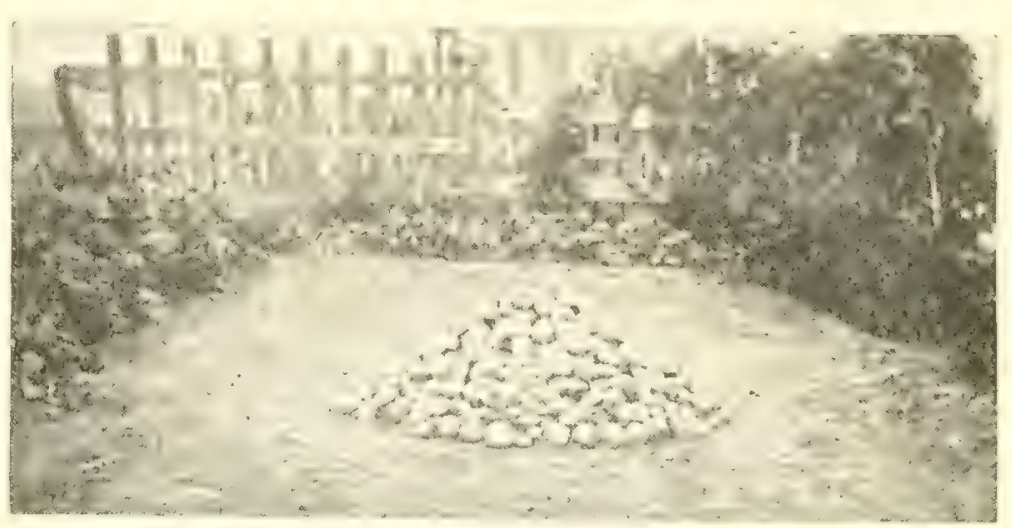

5 bu. of Onions grown on a piece of ground $10 \times 32$ feet in size by Jas. Koser, Abbott, Colo.

and I was well paid for my work, as I have harvested some fine truck, as you will see by the pictures I am sending you.

My best crop was cabbage, onions and turnips. I kept them well hoed and free from weeds, and they couldn't do anything but grow and make good.

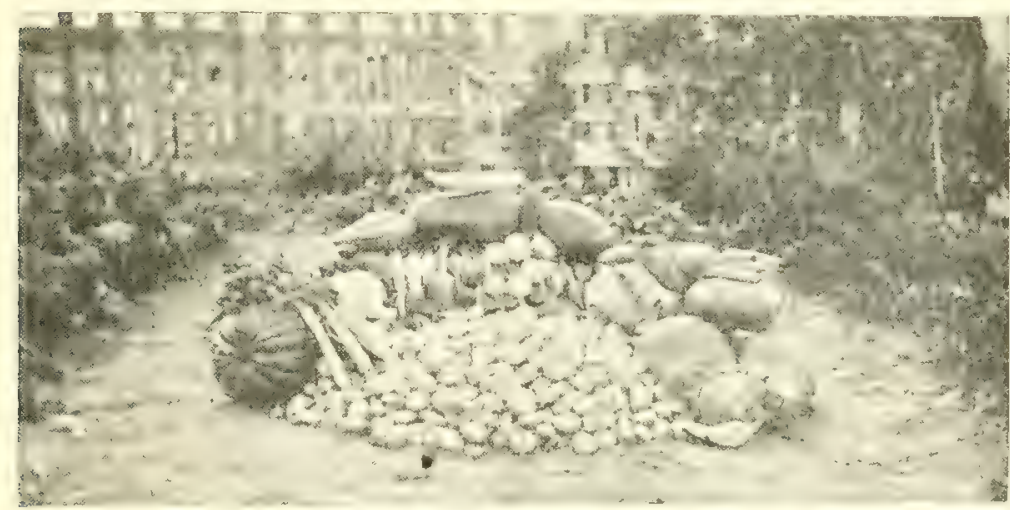

"All of my Onions, 5 bu., and just a sample of everything else I had: see the Celery, ain't it fine-but oh that big, fat Kleckley's Sweet Watermelon on top of the bunch.'?

The only way to get a good garden is to buy good seeds, then put your ground in good shape, and when all danger of frost is past, plant your seeds carefully and not loo thick. When they get up far enough, then begin to use the hoe and keep the ground well stirred, not too deep, and keep free from weeds, and with a fair per cent of rain you will sure get a good profit.

The following is what I got from my garden only $85 \times 73$ feet in size:

Ripe Tomatoes ............. 11/2 bu. Summer Squash ............ 20 bu. Green Tomatoes ..............2 bu. Pumpkins .................65 bu.

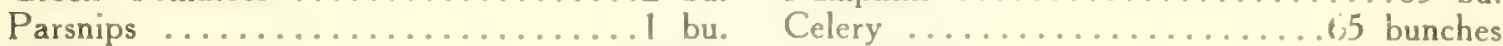

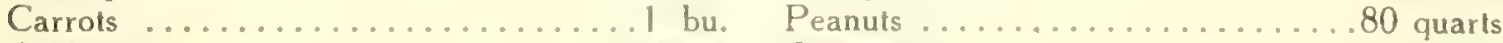

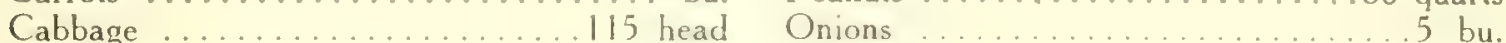

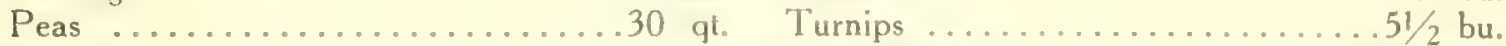

Beets ................... bu bu. Lima Beans .............20 quarts

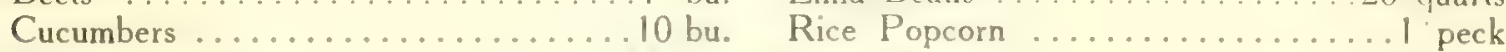

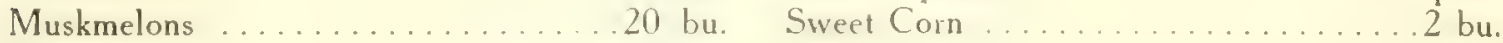

Watermelons ...................... bu.

Jas. Koser, Abboll, Colo

\section{MISSOURI BEATS THE WORLD.}

From Roosevelt Harrell, Urbana, Missouri.

I raised and sold from a small garden $29 \times 12$ yards wide, 20 gallons of beans, $\$ 20.00$ worth, sold $\$ 2.45$ worth of watermelons, $75 \mathrm{c}$ worth of beets, 12 gallons of cucumbers, $\$ 2.45$ worth, $75 c$ worth of onion sets and 50 c worth of peas. Sold $\$ 6.00$ worth of tomatoes.

Roosevelt Harrell, Urbana, Missouri. 


\section{PRIZETAKER ONION BEST.}

\section{From Mrs. S. E. Dexter, Ballagh, Nebraska.}

I could not find any way to take any pictures of my garden, but am sending you my letter and description of my garden anyway. I have about one-half acre in my vegetable garden and a flower bed about 18 feet square. This year I had a fine patch of string beans. They grew so rank and bore so many beans on each vine.

I plant my garden in rows far enough apart so they can be cultivated with a two horse cultivator, and then I hand hoe it all after the cultivator has been over it. I hoe it over two or three times so as to keep the ground loose and mellow.

I like the Prizetaker onion the best of all. They grow the best for me. Pumpkins are so good paying crop for me. I like the Big Tom pumpkin, as it is good to feed milk cows. Our cows, when fed on them give richer and more milk. I raise vegetables for my own use in summer and to can for winter, as we are not where we can market them very handy.

Mrs. S. E. Dexter, Ballagh, Nebrask̨a.

\section{$\$ 30.00$ WORTH OF TOMATOES FROM A SMALL PATCH.}

From Mrs. Joe Ammann, Milan, Kans.

My whole garden, early and late, covered about two-thirds of an acre. Both early and late garden was planted from seeds bought from you, and considering the drouth they all did very well, and some of it did exceptionally well. We have a pump close to the garden run by a gasoline engine, and we ditched the garden ourselves with a small plow

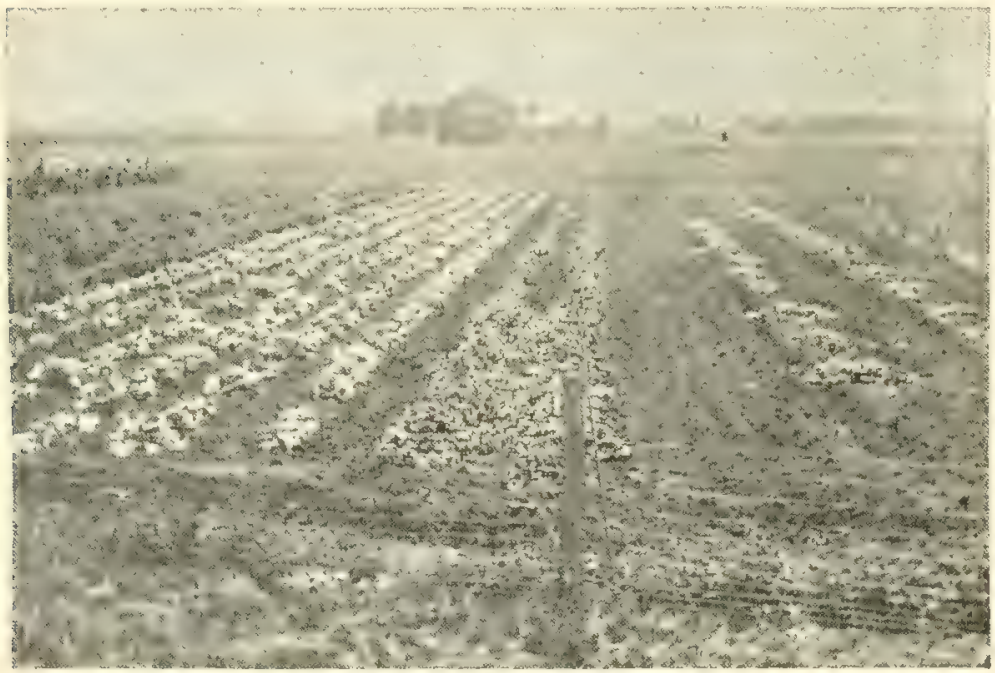

A Fine Garden in Western Kansas in Spite of the Dry Weather. Good Cultivation Did It. and watered it when we thought it needed it. The early garden did very well. The lettuce, your Hanson, was very fine, much went to waste. The peas and beans were cut short by the drouth. but furnished us enough for family use. I planted four quarts of onion sets and we used from them - continually after they had grown large enough for the table, and have dug one and one-half bushel for winter.

The hot winds came in time to cut my crop of sweet corn very short, still we had quite a little for the table. Of my late garden, the cabbage and tomatoes did the best, but the cut worms were bad on the cabbage plants. I put out over 300 cabbage plants, Early Jersey Wakefield and Surehead, but only about 300 lived and they did very well, indeed. Besides using a great deal, giving lots away, and saving a nice lot for kraut, I sold over $\$ 5.00$ worth. You can see from my picture how nice the tomato vines took. 1 put out 50 plants of the Early June and 120 of the New Stone. Although they all did exceptionally well, the Early June did the best. I have used and given away a great many bushels, and have sold, I think, at least $\$ 30.00$ worth.

Like our Irish potatoes, our sweet potato crop is very short, but we have had some for the table. The Watermelons, Improved Kleckley Sweet, came up well and the vines looked fine, but we had all sorts of bugs to fight on them and the melons did not set on well, so we only had a few. My beets, Blood Turnip, deserve prominent mention. They were large, fine and juicy, and I had a nice large crop of them. I credit my success to the watering and general good care. 


\section{EARLY JUNE TOMATO HAS BEEN BEST CLEAR THROUGH.}

From Frank Jones, Stanberry, Missouri.

Enclosed you will fird three pholo views which may show you a little of the general appearance of my garden, but they cannot show you the real pleasure I get out of it.

This has been a very dry season and very discouraging to gardeners, but I have everything planted in rows four feet apart, which enabled me to use a one horse harrow often, and in that way kept things growing.

My garden is noted by all travelers for the beauliful flowers I grow. I have a row the entire length of the garden, commencing at the front with gladiolus, then with different annuals, increasing in height towa:ds the back of the garden, ending with cannas, dahlias and sunflowers.

Pole beans, I plant in hills four feet square

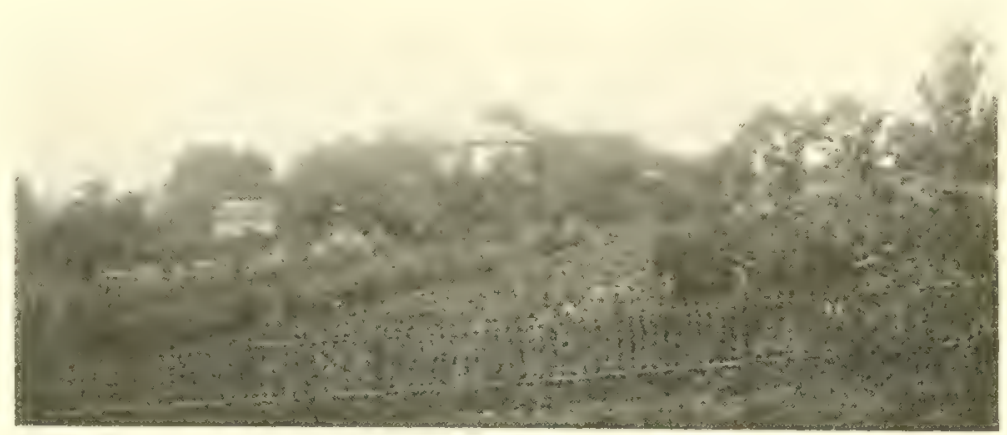

A Typical Misiouri Farm Home and Garden and use poles eight feet long crossed and tied in the middle, which makes a veritable wigwam when covered with vines, and brace each other so they do not blow over like straight poles.

Tomatoes I plant four feet apart each way and drive four stakes five feet long near the plant and flare them at the top and nail lath on the four sides and find it a success. I made a test with tomatoes. I planted Field's Early June, Earliana, Chalk's Early Jewell and Livingston's Globe at the same time and gave them equal care. Early June gave ripe fruit first and has been best clear through.

Frank Jones, Stanberry, Missouri.

\section{SOLD OVER \$50.00 WORTH OF TOMATOES FROM 135 PLANTS.}

\section{From Mrs. F. E. Griggs, Raymond, Nebraska.}

Having little strength, I could not undertake a large garden, but chose early cabbage, tomatoes, celery, peppers, leltuce, endive, watermelons and muskmelons.

February Ist, I started my seeds in boxes in my room, as I do like to watch things grow. Well, I got enough of it this time, for I had over 1,500 plants, and about once a week they had to be thinned out and transplanted until my room soon looked like a greenhouse, and I could scarcely keep up with them. Field's Early June, Earliana, and Shenandoah were close rivals, and my cabbage plants came up so thick that it almost seemed that several plants came from each seed. I learned not to try to raise over seventy-five plants in three windows again, but to get hot-bed sash and make a hot-bed or cold frame.

This was a queer year, and early in April I had to begin carrying out the boxes and tin cans of plants into a little sunny spot, I fenced with 7 foot netting. I corered boxes over them at night, but often had to wheel them back and into the house for night.

The first buds were seen on the tomatoes April 19th, and I continued trying to harden them, and May Ist we had several inches of snow and many under the boxes were frosted, while three had been set in the ground early in April came through in good shape. It was May 9th to 16th before they could be gotten out into the ground, and after giving away about 50 tomato plants, I had 135 left for my. own little garden. The first blooms came May 19th. I made hundreds of paper boxes for the tomato plants, but found it does not do to transplant into them more than one week before they are to go out into the ground, as the soil bakes and dries out and they turn yellow in spite of good care.

The early cabbage, when set out, began to grow well. The cut worms took it bad, and then it suddenly seemed at a standstill for want of moisture. But it held it's own well until rains came and made a good crop. When I set out my tomatoes, they were given a quart or two of liquid fertilizer. The weeds were kept down and hoed the best I could, which wasn't half good enough, and they were soon suffering for water, as it was very dry then. 


\section{THE BOOK OF A THOUSAND GARDENS}

I had worked very hard for four months, and my garden was a very nice one and I couldn't see it die, so started in to carry water (a' long distance up a 30-foot creek bank). But it did not rain until fall. I carried and carried waler and liquid fertilizer and finally give out and quit. The tomatoes in the start set a large crop, and then for weeks the blossoms could only dry and fall off, but the fall rains washed the fertilier down and they again set the largest crop I ever saw. I pruned my vines severely and also pinched off all tomatoes that would be gnarled or poor shape, as soon as I could see them, and it paid well in the nice crop of smooth ones I got. The first were ripe July 4th, and on July 8th we were already oversupplied and began selling the surplus to people who had no gardens at all this year. They were 15c per lb. at first, and people said, "Too dear to eat," so my first ones went at 3c. Later, as they acquired a taste for them, I got $5 c$, then $71 / 2 c$ and $10 c$, but always $3 c$ to $5 c$ under the lown retail price, although I had to deliver them.

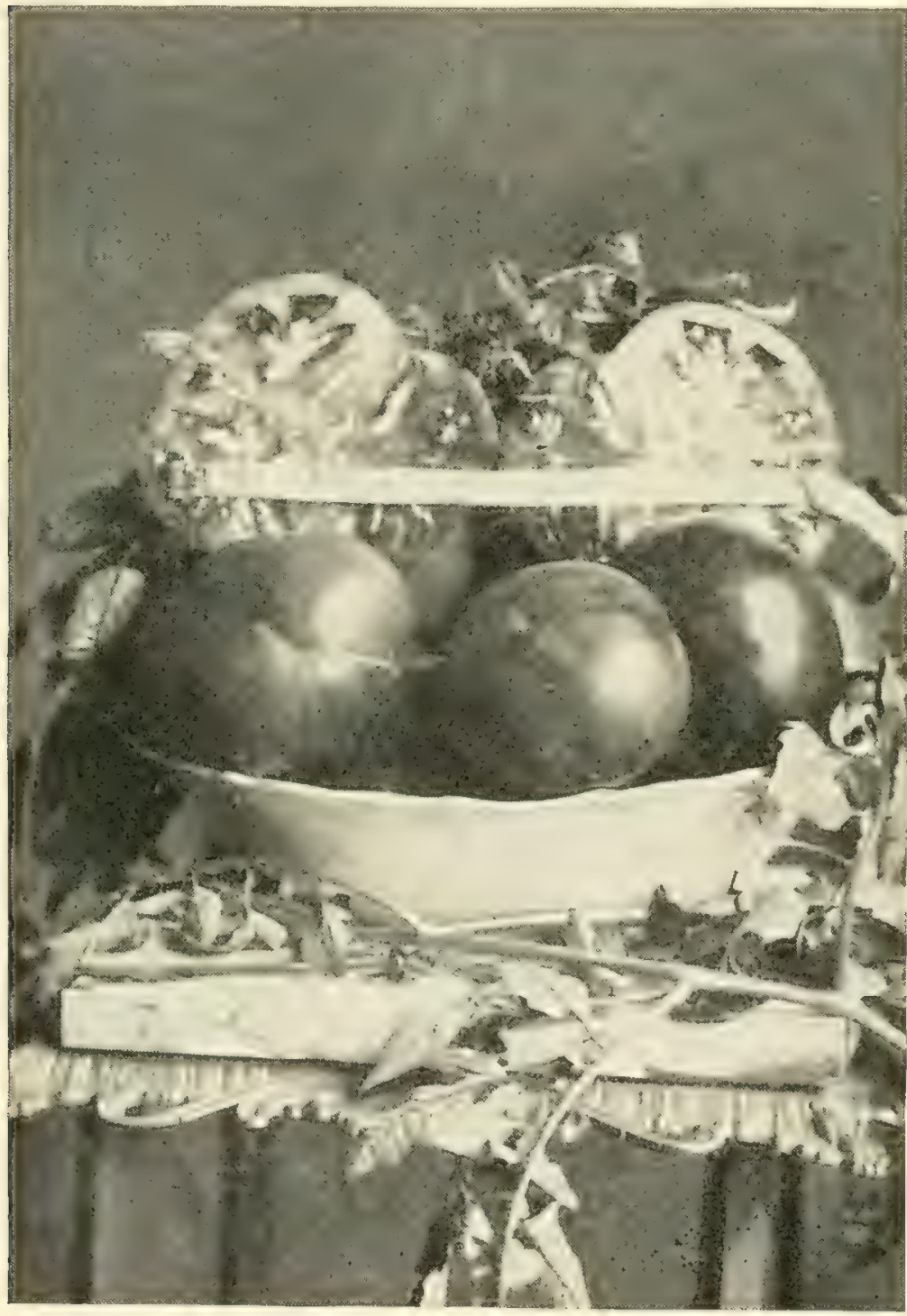

Beautiful Sample of Field's Early June Tomatoes

This was just my little home patch of 135 plants. On Aug. 26th they dropped to $5 \mathrm{c}$, as people were just getting a few scattered ones of their own, and up to that date I had sold $\$ 50.00$ worth. They were then coming so fast that I had to go on the jump almost to dispose of them, and in my haste one foot slipped from the buggy step and I fell, breaking and badly crushing a limb just above the ankle. So that ended my garden. Not entirely either, for my heart was down there and the following week with this fractured limb in a plaster cast, I crawled down to it and gathered them and tried 10 reach the house with a bushel of them, and it has relarded my progress, until now, two months later, I am still unable to walk much. I then had to give the patch away, and there have been fully 40 bushels eaten, given away and wasted besides my $\$ 50.00$ worth sold; and the frost has just caught the vines uncovered with an enormous crop of ripe ones and green ones in all stages, just bushels of them. There are more now left on the vines than ever set in one season before, I think. That last week I was obliged to go every day to market them and could not deliver them fast enough from a buggy. During those two months, I was the only person in this part of the country who had a tomato.

My tomatoes surely did well, and if 135 plants can do this well, an acre would surely bring in more than most 160 acre farms do. I hope some day to see just what an acre of these Field's Early June tomatoes will do.

Mrs. F. E. Griggs, Raymond, Nebraska. 


\section{A FINE GARDEN IN OKLAHOMA IN SPITE OF DRY WEATHER.}

From Mrs. R. C. Lee, Okmulgee, Oklahoma.

Well, the dry weather struck us here and my garden was not as good as I wanted it to be, but it best everything around here. People came from far and near to get garden truck of me. Two were here today and got cabbage. I did plan to sell all my extra vegetables to pay for photographs of my garden, for this garden, but four years ago my garden failed and people were kind and gave to me, so I felt I must do as I wish to and had been done by, so I gave it away.

My garden was one-half acre. I manured it, plowed it, lightly manured again, and thoroughly harrowed it. Got me a combination garden plow, bought my seed from Field Seed Company, because I know they will grow and yield, and without such seed you need not expect a good garden. I had four rows of sweet potatoes, raised $41 / 2$ bushels, and the biggest one weighed $61 / 2$ lbs. Eight short rows of Henderson's Bush Lima. Had beans through the summer and put away 12 lbs. for winter. One bush had 150 pods. Ten rows of onions, and I raised about 20 bushels. Four rows of string beans. Had beans up until frost. Two rows of Early June tomatoes. Had tomatoes by the water bucket, plenty for winter, made green ones into chowchow, and some 10 spare. Four rows of cabbage, but they did not do so well. Plenty of radishes. Had one row of oyster plant-doing nicely.

With my little combined plow, I tended my own garden.

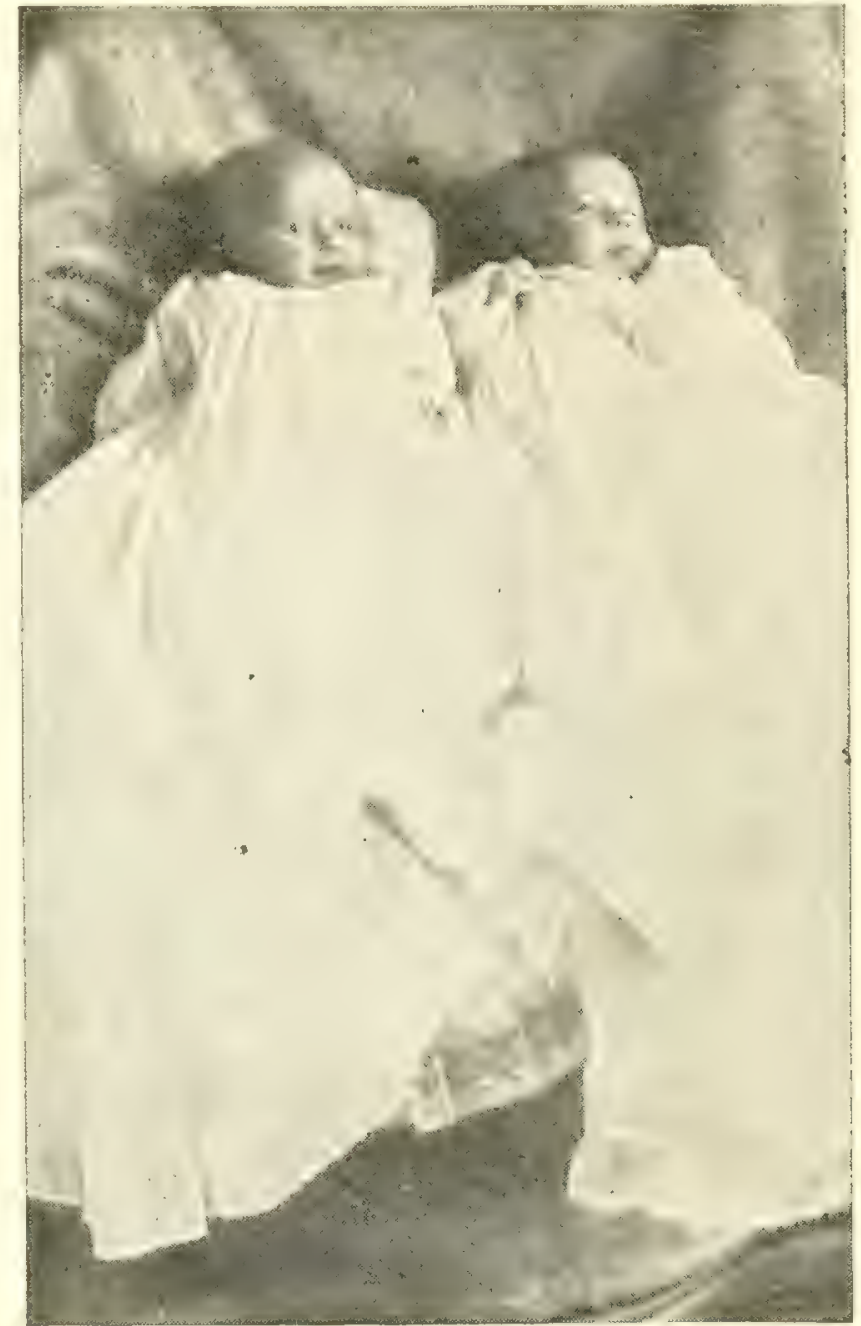

Twin Babies. Mrs Lee says that if the Prize had only been offered for Babies she would have been a Winner.

Now last but no means least, and to cap the climax after all of this gardening, on the 29 th of July, 1911, was born to us twins, a boy $6 \frac{1}{2}$ lbs. and a girl $6 \mathrm{lbs}$. Oh, if the prize had only been offered for babies instead of garden, I would have been all right.

I am sorry I didn't get any photos, but I had no kodak and don't know any one that has, and it would have cost me $\$ 5.00$ to have a photographer come way out here to take them and I could not stand the price.

Mrs. R. C. LeE, Ormulgee, Ollahoma.

\section{GOOD SEEDS MOST IMPORTANT.}

From J. M. Masters, Bird's Point, Missouri.

I am so.well pleased with gardening that I give it quite a great deal of study. First, it is very essential to remember that everything bears fruit after its own kind. A garden has to have good seed, and either raise and save some or have some good reliable seedman to buy from, and when a gardener can find one of this kind, he should never change an old friend for a new.

J. M. Masters, Bird's Point, Missouri. 


\section{ALWAYS SCRATCHING IN THE GARDEN.}

\section{From Mrs. T. K. Clark, La Porte City, Iowa.}

The dry season has made gardens almost a failure. My early garden same as usual, the seeds came up just fine, but the beans and peas dried up just as they began bearing. So after the drouth was broken, I didn't do a thing but go and get my seed box and replant again, and I now have prospects for a fine garden.

I do believe in keeping out the weeds. My husband sometimes calls me an old hen, says I am always scratching in the garden. I do not raise garden to sell, but have a plenty for our own use and always have some to give to my neighbors. They are sure to say, "Oh, such peppers, - cabbage,-Why those lovely peas-Where did you get the seeds?" That is why $I$ send the neighbors a mess.

I will try and send you some potatoes a little later. My Royal Red tomaloes are looking fine.

Mrs. T. K. Clark, La Porte City, Iowa.

\section{A CITY GARDEN.}

From J. Griffin, 4134 Labadie Ave, St. Louis, Missouri.

My lawn is $40 \times 90$ feet and the walks is a little to the left of the center of the yard. I have no flowers whatever in the yard proper, all are alongside the fence all the way around.

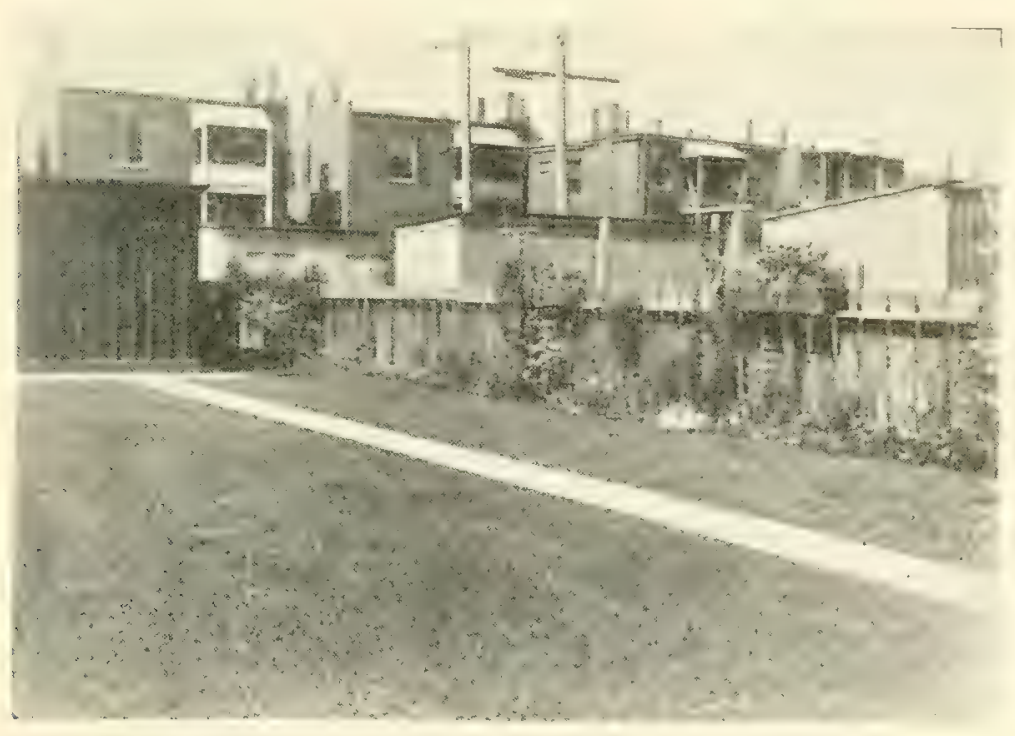

A Beautıfu Flower Garden in a City Back Yard

I have nailed on the fence 6 flower boxes, 3 on each side, and my ash pit which is near the alley is also decorated with a flower box. About two feet from the fence all around the yard I planted rose bushes, various kinds, Balsom of all colors, Petunias, Portulaca, Althea, Hibisca and Geraniums. Clinging to the 6 laundry posis that are against the fence, I have a seven sister rose bush that climbs and spreads most beautifully and in June is a mass of bloom. At each end of the shed on the lawn I have posts

driven in the ground and have a flower box set on each of the posts. In each box I have a large fern in the center and Petunias on the edge. The Petunias bloom constantly and it looks from the house as though the fern is in bloom.

In arranging the flowers $I$ try to get the best out of the colors and have a continual bloom. My yard is the prettiest in this end of town and very easily kept. The green grass in the center of the yard not broken by any flowers is a sight to behold. All the seed was bought of your firm and most of the shrubs. All of the grass seed came from you.

J. Griffin, 4134 Labadic Ave., St. Louis, Missouri.

\section{\$102.50 FROM ONE-HALF ACRE OF TOMATOES.}

From Dock Crutchfield, New Tazewell, Tennessee.

My best crop was Field's Early June tomatoes. I sold my seed March 5th and planted in field May 5th. Picked ripe tomatoes July 1st. Put a tablespoon full of fertilizer to each hill and worked three times. One-half acre paid me $\$ 102.50$ clear cash. This one-half acre of tomatoes means customers to Henry Field Seed Company from here. Dock Crutchfield, New Tazewell, Tenn. 


\section{GAVE, PLANTS TO HER NEIGHBORS.}

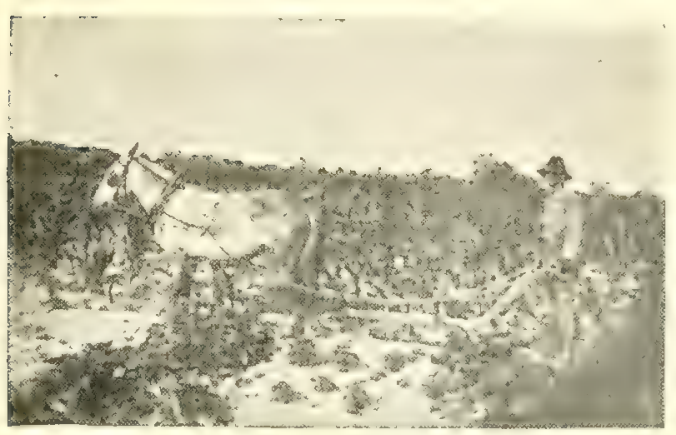

Ploughing in Mrs. Park's Garden

From Mrs. Lola T. Park, Bryan's Mill,

Texas, R. R. No. I, Box 50.

Our garden has been our salvation. It is one-fourth of an acre. Half of it is planted to squashes for hogs. Have no market, but feed hogs and chickens and sell them. For three years we have had very little rain, but we buy seed direct from "The Seed Man," they germinate quickly and we get a good stand. To my neighbors, who bought as much seed as I did, but from local dealers, I gave seventeen hundred and fifty cabbage plants.

I had five varieties of peas, a ten cent package of each, and gathered from one-half to a gallon daily from April 14 th to June 8th. Other things were even more abundant; we feasted on vegetables and supplied our neighbors to a great extent until the middle of June, when the drouth ruined everything. And we have a bountiful supply of dry and canned vegetables for winter use, while they have none. There is no estimating the amount of beans gathered from four 50

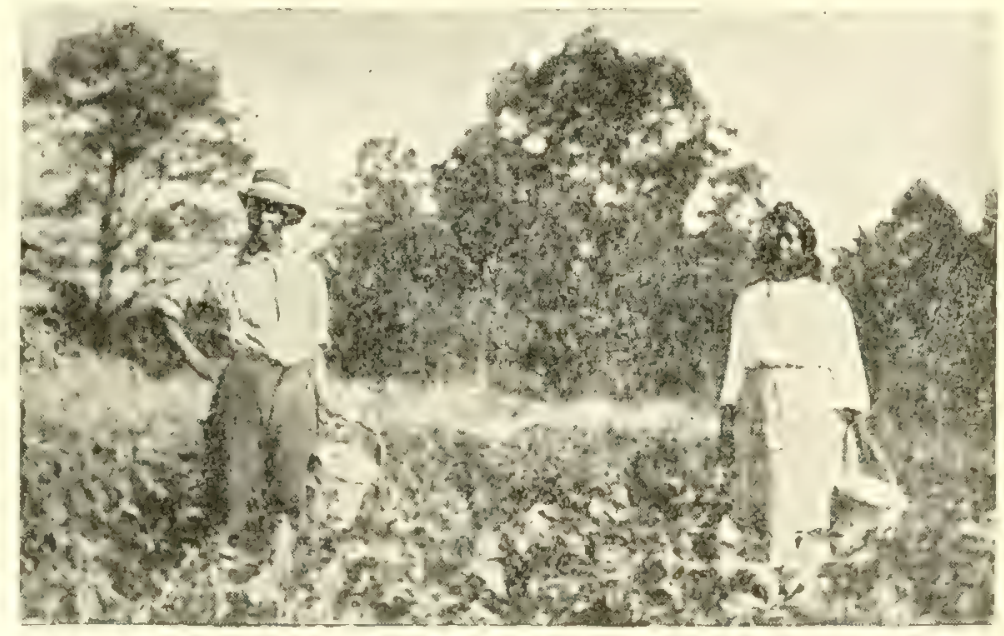

Gathering Beans to can for Mrs. Park yard rows of Bush Limas, and we have one-half bushel of shelled beans.

Mrs. Lola T. PARk, Bryan's Mill, Texas, R. R. No. 1, Box 50.

\section{TAKES LOTS OF HOEING TO MAKE A GOOD GARDEN.}

From Mrs. H. Myer, Lancaster, Kans.

I live fourteen miles from a photrgrapher, so it will be impossible for me to have any pictures taken of my garden, but will tell you what kind of a garden I have. On account of having very dry weather here this year, my garden wasn't what it would have been if we could have had rain, although we had a fine garden to what others had in our neighborhood.

We have an acre in our garden. We raised this year, radishes, lettuce, beans, peas, onions, beets, cabbage, corn, tomatoes, cucumbers, sweet potatoes and watermelons. We had a success with everything excepting cucumbers, and it was entirely too dry for them. We have had cabbage and tomatoes to use ever since the middle of July, and that is more than any of our neighbors can say.

I have used your seeds for three years and can say that every seed I ever planted of yours has grown, and I will not do without your seed as long as I can get it from you.

My garden was well manured and plowed in the fall. This spring it was harrowed and then ready for the seed. I sow my seed in rows across the garden. I find out it takes lots of hoeing to have a good garden, which my daughters and myself do without the assistance of a man. 


\section{POUNDS OF TOMATOES FROM 20 PLANTS.}

From James C. Shield, Monticello, Ills. FROM JAMES C. SHIELD, MONTICELLO, ILLS.
My garden is about half an acre. I raised nearly every kind of vegetables. I will
mail under separate cover a drawing of my garden showing how it was planted and how much I raised of each kind of vegetable.

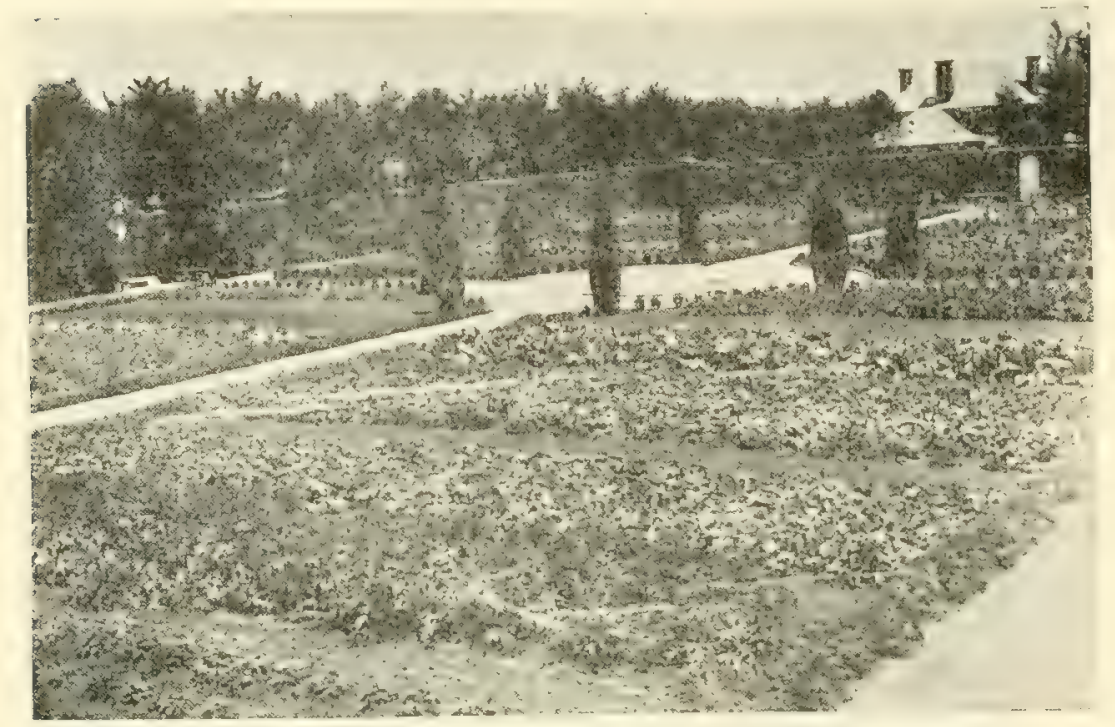

A Beautiful Half Acre Garden which yielded over $\$ 500.00$ worth of Vegetables. Notice how clean it is. Not a weed in sight.

First I sowed my onions, carrots, parsnips, beets, spinach, peas, corn salad; and then planted onion sets, cabbage, onions, beets and kohl rabi that had been started in hot-beds.

My best crop was tomatoes. I grew four varieties on a trellis. The following speaks for itself: Earl y June was easily first, 20 plants, 540 lbs. New Stone, 20 plants, 495 lbs. Tall Champion, 20 plants, 433 lbs. Table Queen 416 lbs.

My late celery is also very good. I dug a trench 15 inches deep and put about four inches of manure in the bottom and spaded it under two weeks before planting my celery. Then I planted a double row celery in the trench, planting alternately. When the plants grew enough to require soil around them, I threw the soil in around the plants without getting soil in the hearts, which rots the plants.

Last fall, I cleared every small weed out of the strawberry bed, gave it a dressing of manure, worked it a little. When the ground was frozen I mulched it with straw. In the spring I took the straw off the tops of the plants but left it in between to keep the berries clean. Then I took wood ashes and mixed them with bone meal and top dressed the plants with this mixlure where I had taken the straw off and let the rain wash it in. From six rows of strawberry plants 200 feet long, planted the previous spring, I picked $\$ 100.00$ worth of fruit.

Melons were a very good crop but season was short owing to dry weather. The best amongst my muskmelons was Field's Daisy. It was early and of excellent flavor. I tried 22 varieties and found Field's Daisy the best. Its vines resisted disease and stayed green longer than any other variety. The fruits were uniform size, and the last melons I picked from the field were Daisy. Next best was Milwaukee Market.

On June 13th I planted $11 / 2$ bushels of New Yorker potatoes, covered them with straw, and last week dug 21 bushels from $11 / 2$ acres.

The best thing I found to keep butterflies off of late cabbage is asafetida. Use one or two cakes in a three gallon can of water, let set to dissolve, then sprinkle the plants. Repeat in about ten days or two weeks.

James C. Shield, Monticello, Ills.

\section{KEPT CABBAGE WORMS AWAY WITH SALT.}

From Mary SAUER, New Paltz, N. Y.

My garden is 28 feet wide and 32 feet long. May 9th I planted beets and radishes in the same row. When the radishes were large enough I pulled them out and made room for the beets to grow. May 10th, I planted potatoes. I made a deep furrow, planted the potatoes about fourteen inches apart and covered the furrow full of dirt. After two weeks I raked most of the dirt off so the sprouts would not get too tall. 
May 12th, planted Swiss chard. All of my garden seeds I put down four times their thickness. Sweet corn, 1 put four seeds in a hill. The hills were three feet apart in the row. May 13th, I planted muskmelons and cucumbers. May 15th, planied popcorn. May 17th, transplanted lettuce. I started the plants in a hot-bed. I set them a foot apart in transplanting. May 18th, I transplanted beels, and May 19th, transplanted potatoes that I had planted in a box in March. This made early potaloes.

May 20th, planted squash in hills. Kept them sprayed for striped bugs and blight. When a little squash is on, nip off the end of the vine and the squash will grow much larger. May 22nd, planted peanuts. May 22nd, transplanted sweet corn that I had started in a cold frame. May 23rd, planted ground almonds, horehound and lavender. May 24th, transplanted onions. May 25th, planted lima beans and string beans. May 29th, transplanted tomatoes three feet apart. May 29th, transplanted peppers, and May 30th, transplanted cabbage. When any worms ate at the heads, I put salt in the heads and that killed them.

When the lettuce and beets were pulled out, I planted some more lettuce there. I planted it so I could cover it up in case of frost. I planted corn on the north and east side so it would not throw a shadow on the garden. Next year I am going to raise things for the fair.

Mary Sauer, New Paltz, N. Y.

\section{AND THE BOYS ARE LEARNING HOW.}

From Mrs. H. Bevington, Galveston, Indiana.

Our garden was for home use for a family of six, four grown people and two children. It is one hundred and thirty feet long and thirty-six feet wide.

The beginning of the season was very dry, but with the help of our two little boys, we cultivated often. The dust mulching is a good thing. We kept stirring the ground with the garden plow and kept our plants growing. Our garden was beautiful and when late rains came, everything was in fine condition. An abundance of vegetables was raised.

A new plan for sweet potato ridges was used. First, a deep furrow was made, this was filled with manure from the hen house. The ridge was made over this, and when cultivating we plowed deep between the ridges and pulled the dirt up to the plants with a hoe. This made a wide ridge. Our sweet potatoes were fine.

We sprinkled our cucumber and melon vines with lime. This keeps off the bugs and the little black insects that attack them. For the insect on the under side of the leaf, we use weak, paris green water. We keep worms from cabbage with cayenne pepper, sprinkling it on in the morning. It can be mixed with dust or black pepper.

Mrs. H. Bevington, Gaiveston, Indiana.

\section{A FINE GARDEN ON A CITY BACK LOT.}

From Wm. Todd, Minneapolis, Minn.

I have had a good time with my garden this year, although it was only a city back lot. From one of your ten cent packages of Early Champion Sweet corn I grew ninety hills, three kernels to the hill. I also grew two pumpkin vines, 2 hubbard squash, and ten mixed Summer squash in between the corn. Then there was my tomatoes. I had one dozen Field's Early June tomato plants grown fom seed, three Yellow Pear tomato plants. I also had a patch of Keckley Sweet watermelons, one of Princess watermelon, (a fine juicy melon it is, too), and a patch of Perfection Muskmelon. Cucumbers and beans occupied the rest of the ground. This was all in one city lot, something every three feet.

I worked nights, planting after working down town all day until all was planted. I then waited a week for the weeds to break through, and then went all over the patch to make sure

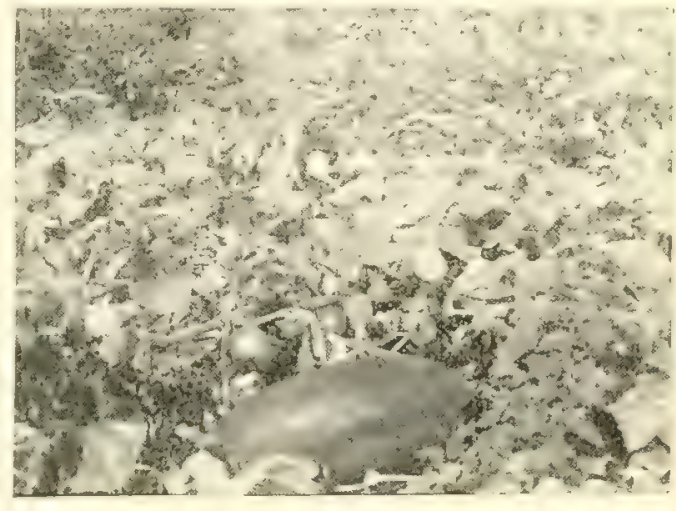

Watermelons and Tomatoes in a City Back Yard they were all killed, and so on until the crop starled in good shape. I kept the ground pulverized around the roots well. 


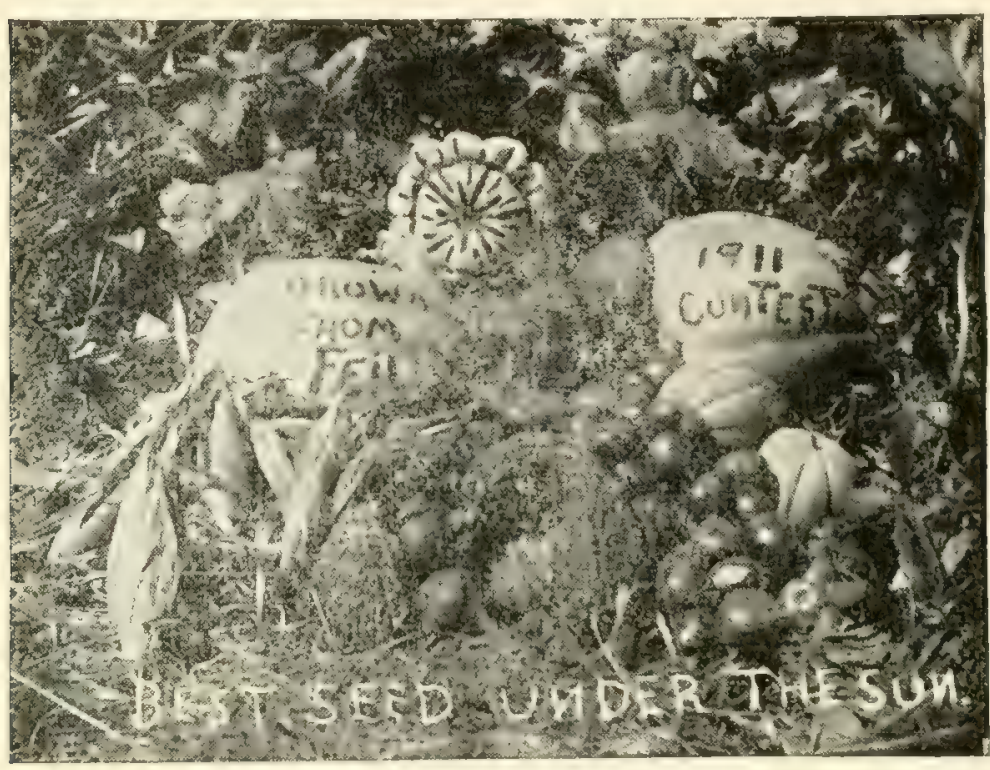

Products of a Baok Yard City Garden

I was as pleased as I could be watching and counting the melons and tomatoes as they would appear. I also had a patch of potatoes about $20 \times 20$ feet, out of which I took two bushels. I think I realized more money out of them than anything else, as they were the highest price.

In all I got five pumpkins, three hubbard squash, 55 s u m m er squash, ten various melons of good size, three bushels sweet corn, $11 / 2$ bushels tomatoes, onehalf bushel Lima Butter beans. In all I am very well pleased with the

sumer and many thanks to your extra good seed.

WM. Todd, Gen. Del. Minneapolis, Minn.

\section{A CRIPPLE AND HIS GARDEN.}

From John Wm. Padget, Chesterfield, Illinois.

I have had to carry my water quite a ways and the garden didn't get what it really needed, but with the Lord's help I cannot complain. I think I have done fine, as I am crippled up with rheumatism, and anyone in my shape ought to be thankful for getting around to do a little gardening.

I haven't a big patch like some, but I manage to get a lot of stuff in and sell at a fair price. My garden will, I think, bring in about ten or eleven dollars by the last of the fall. Some would not think that much, but I do with about $18 \times 20$ feet of ground. Every nook and corner goes in, you bet.

If I was not lame, I would be willing to test any man on earth for a truck patch 100 feet square, but $18 \times 20$ isn't big enough, is it? But a bachelor don't need a big lot.

J. W. Padget, Chesterfield, Illinois.

\section{GOOD ADVICE.}

From A. A. Reams, Des Molnes, lowa, Gen. Del.

All I can write about is of the efforts which I made. My main crop was onions, and after doing special work in the preparation of the ground for the seed, on May 15th I had as fine a prospect for onions as I ever saw, but lack of water from that time on ruined the crop.

Having failed to a great extent in my garden products I have no results to mention and can only add a few general suggestions for garden work:

First, prepare the seed bed in the best possible manner. Do not slight the work at this time in any way. Labor at this time will show good results later in the season. Garden seeds are delicate and they cannot grow well only in a well prepared loam.

Second, plant only good seed. Do not run any risk in having poor seed. Do not buy seed because it is cheap. Patronize a responsible seedsman, and when by experience you can have perfect confidence in his seeds and his representation of them continue to patronize him.

Third, after a well prepared seed-bed has been planted with good seed, start cultivation as soon as the work can be done. Banish all weeds-much of this must be done by hand weeding-and after the weeds are destroyed, continue to cultivate. It must be remembered that damaging insects will injure as much as weeds and these must be banished, too.

A. A. Reams, Des Moines, lowa, Gen. Del. 


\section{LB. CAULIFLOWER AND 24 LB. CABBAGES.}

From J. F. Heritage, St. Maries, idaho.

A story of a garden is hard to write,

Especially where you have weeds to fight

Ten hours per day and half the night.

With some, gardening is for pleasure, but with me it is for both pleasure and profit. In some locations, one profits more on some vegetables than on others. Here in this great lumbering and mining district, I find it more profitable to raise such as polatoes, rutabagas, beets, turnips, cabbage, carrots and onions. These the camps buy by the ton and hundredweight. When I had a large city for a market, I raised besides these named articles, lettuce, corn, cauliflower, tomatoes, beans, peas and all such truck. I find again that Rhubarb is one of the most profitable articles in the west.

Greatest in consideration is the proper kind of seed. I never found it practical or profitable to buy seed from Tom, Dick and Harry just because you can get it cheap.

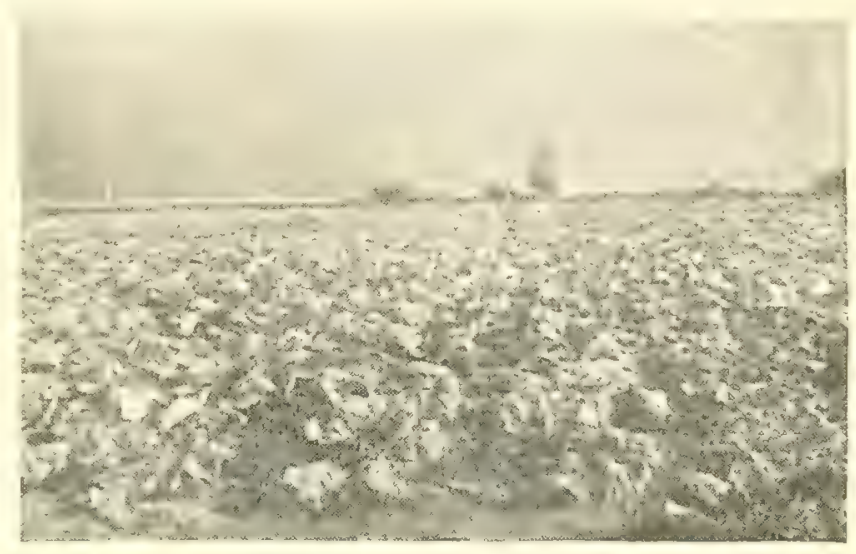

4000 Volga Cabbage 6 Weeks old

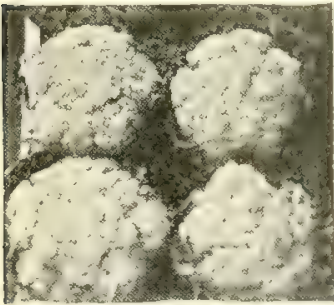

These 4 Heads of Caulilower Weighed 25 Lbs.

Find a reliable man and stay by him, and when you order seed, you get just what you order.

From seed purchased from you, I had cauliflower this season that weighed 8 lbs. per head, cabbage, Danish Ball Heads, that went to 24 lbs. Turnips and Rutabagas that weighed 12 lbs. each, and winter radishes that averaged 6 lbs.

I won quite a few prizes at our County Fair, also at the Spokane Inter-State Fair, and always made it a point to say the seed came from Henry Field.

J. F. Heritage, Sl. Marics, Idaho.

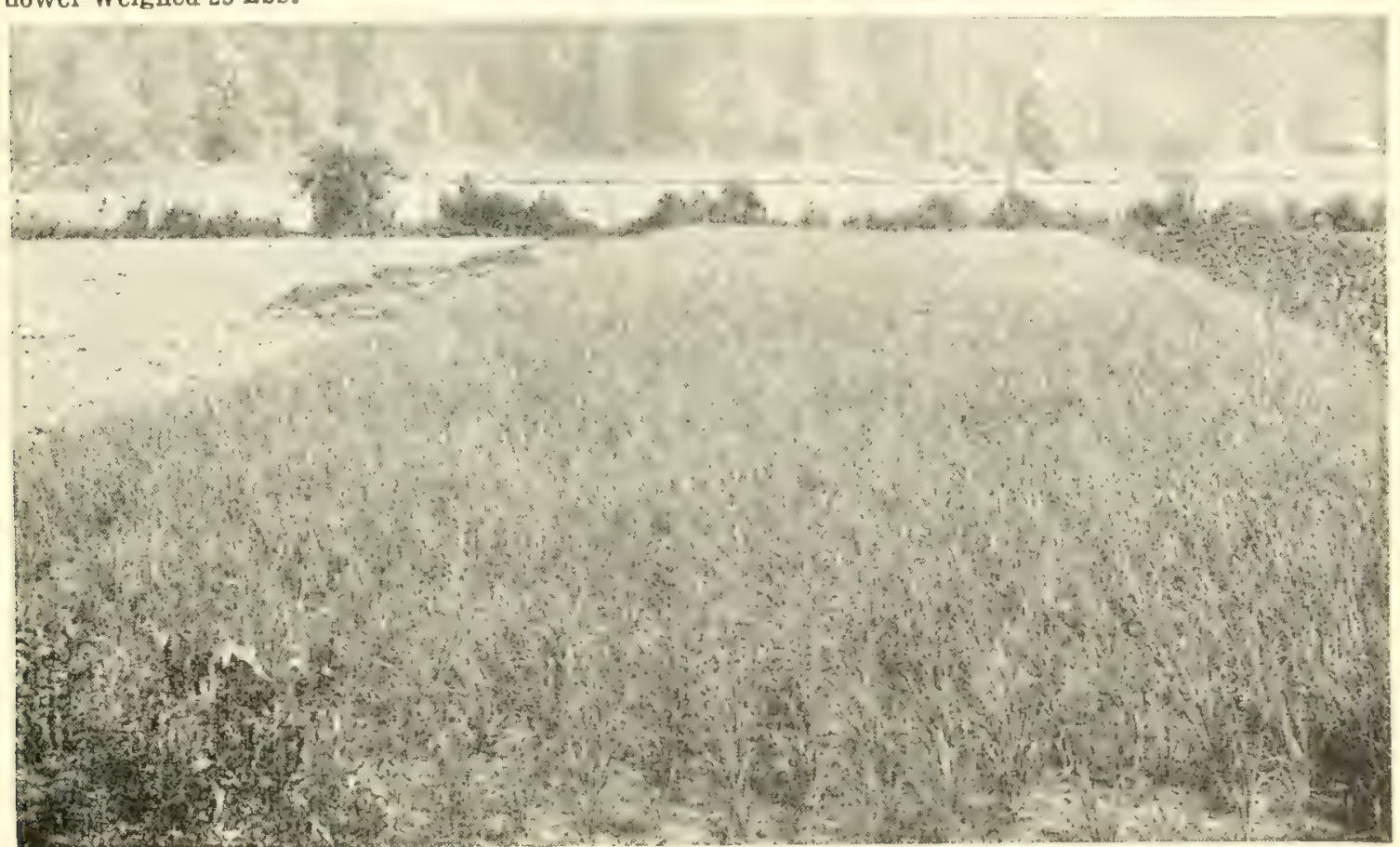

A One Third Acre Field of Onions that cleared up $\$ 150.00$ 


\section{CAULIFLOWER PAID WELL IN SOUTH DAKOTA.}

\section{From Charlotte Everlein, Aurora, South Dakota.}

Will write and tell all about the sowing, planting, cultivation and plans of my garden. The garden is south of the house and slopes toward the south, and the west side is bordered by an orchard. The garden is eighty feet wide and a hundred feet long. The beds run the full length of the garden, and for the herbs and small vegetables, the beds are ten feet square with an eighteen-inch path between the beds.

First, the soil was fertilized in the fall and spring. Then it was harrowed and plowed in the spring and harrowed with a small harrow four times and then with a hand rake. It was raked until it was perfect and smooth.

The flowers were sowed and planted in the front of the garden in a park-like way. Then the vegetables were sowed and planted as follows: Rutabages were sowed in rows eighteen

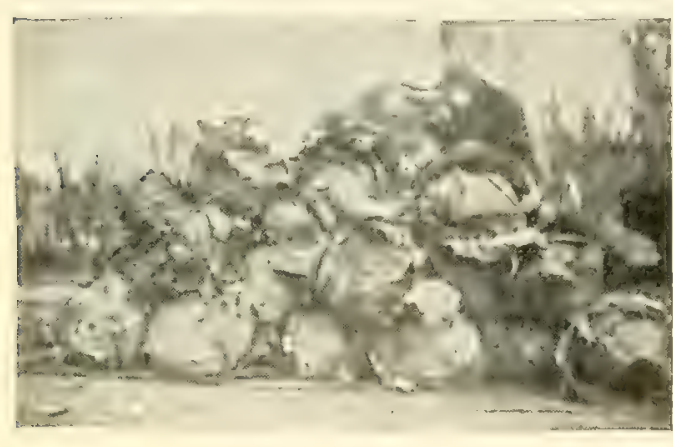

Some mighty fine cabbage. inches apart and thinned out to about six inches. The turnips and carrots were sowed the same way. The celery, tomatoes, peppers, cabbage and cauliflower were sowed in a hotbed in March and transplanted in May.

The celery was transplanted in a trench. First we dug a trench eight inches wide and twelve inches deep, then two makes of fertilizers were put in, then two inches of the fine and heavy soil was put in the trench, then the celery was planted and watered and shaded for two days. Then as the celery grew, the soil which was dug out of the trench was placed back, and then if the celery grew higher than the trench, the ground was hilled up.

Tomatoes were planted in a row three feet both ways, and the cabbage was planted in rows two feet both ways, and cauliflower and peppers planted eighteen inches apart. Cucumbers were sowed in hills four feet apart both ways. In May, watermelons and muskmelons were sowed in hills six feet apart. Onions were sowed in a row eighteen inches apart.

The most important thing this summer was watering. The best way to raise prize garden crops of vegetables is to have your vegetables early. The soil must be very rich and watered, and for those who can have fertilized juice, it is better than water. The ground must be kept free from weeds and well hoed.

The most profitable of vegetables is cabbage, cauliflower, tomatoes, onions and celery. I had one-hundred and eighty-five heads of cauliflower, and I sold a hundred of them. The head measured eight inches in diameter and sell from a shilling to fifteen cents Charlotte Everlein, Aurota, S. D. a head.

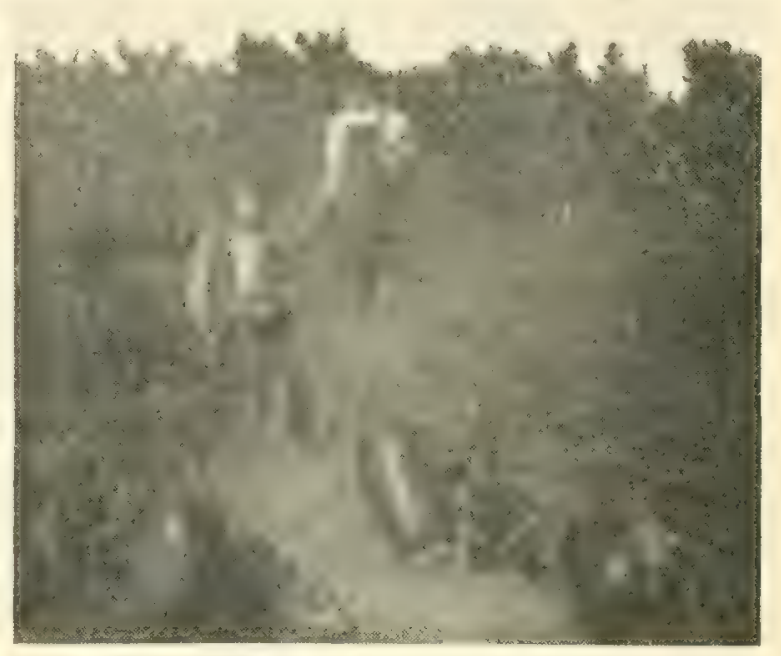

Princess and Kleckley Melons in S. Dak.

\section{TOMATOES AND SWEET PEPPERS HER SPECIALTY.}

From Mrs. N. D. Tidball, Fayetteville, Ark.

I never tried so hard with such poor results, for we had no rain from early in April till July 15th.

My garden is intended mainly for family use, but if there is a surplus we sell it in our "hit cr miss," "lake what you can get" market. Last year I sold $\$ 42.00$ worth and had planned to do much better this year, but the drouth queered my plans. As I have a 
large family (never less than ten at the table), I must have a large garden, a little more than an acre, $300 \times 150$ feet.

As soon as a child is large enough to find a bug or drop a plant, I try to get them interested in "our garden." We use a wheel hoe, and it is just fun for the little fellows to run it. I have two hot-beds, one $6 \times 6$ for starting plants, another twice this size for cansplanting for larger growth. In March I make a main planting of onions, radishes, leltuce, mustard, spring turnips, peas, carrots, parsnips, salsify and beets; and plant in a hot-bed Early June tomatoes, peppers and egg plant, as it is not safe to set these out till the middle of May. My tomato plants are usually beginning to bloon when transplanted. I prefer a cold frame for cabbage, as the plants are more hardy and stand transplaniing better. To protect cabbage plants from cut worms which are so destructive in the cool spring weather, wrap the stem of each plant in paper before setting out. Treat early tomato plants the same way.

As soon as spring is really here, I plant beans, butter beans, cucumbers, squash and other tender vegetables. From this lime on there is not a week that something is not planted for succession. About the middle of June the early potatoes are dug and the ground on which they grew planted to popcorn, bush limas and tomato plants for late crop. I plant all vegetables that mature together in a group, so that the ground may be cleared and planted to something else.

I kept my vegetables alive during the long drouth-barely alive-by frequent stirring of the soil. My plan for having late cabbage is to plant All Head Early, setting strong plants late on the richest soil, cultivate them often and do everything I can to make them grow faster than the worms can eat.

I have Iwo specialties, tomatoes and sweet peppers. By planting Early June tomato for first crop and starting in hot-bed and planting Stone, Shenandoah and Golden Beauty for main crop, we have fresh tomatoes on the table all summer, beginning the middle of June. Sweet Peppers I raise for market mainly. They are so easy to raise and handle and yield more for the trouble than anything else. I plant the Chinese Giant.

One's own experience and common sense are the best garden helps. Study the soil and climate in which you live and plant such things as are best adapted to them.

Mrs. N. D. Tidball, Fayelleville, Ark.

\section{A GOOD GARDEN IN MISSOURI.}

From W. A. West, Livonia, Missouri.

My garden is in two parts, one on the east and one on the west of my dwelling. The one on the west consists of a patch $6 \times 10$ rods. Three years ago it was a piece of sod, and I hauled stable manure and gave it a good coat. This, I lurned under very deep and let it lay till spring. Then I gave it a coat of well rolted manure and stirred it thoroughly with a double shovel and then harrowed it. I have given it a coat of manure each year since.

This season, I planted onion, lettuce and radish seed, also beets and peas about the middle of April, and about the fifth of May I planted late cabbage seed, and also transplanted early cabbage and tomatoes.

Now, to make a long story short, I have kept this garden thoroughly cultivated and clear of weeds. I also, during the long dry spell, hauled water and irrigated it every other day. The result is I have raised an abundance of all the above named vegetables.

In the accompanying photograph you can see some of my Princess watermelons, Cornbelt Cabbage, Missouri Wonder Pole Beans, and Early June lomaloes with myself slanding in the cabbage palch.

The plot east of the house, I planted in potatoes, sweet corn, beans, butter beans and 
watermelons. This piece of ground is an old garden spot and feed lot consisting of one acre. This ground is very rich, but it was too dry this season for the best results.

The watermelons on this ground, I planted the tenth of May. I first broke the ground and harrowed it thoroughly. Then planted about 15 to 20 seeds in a hill, and when they came up I hoed them and plowed them one time, then hoed them again and thinned to three or four in a hill. This is all the cultivation I gave them, but I raised a fine lot of melons.

It was too dry for potatoes, although I raised about a half crop. I get the best results by only cultivating potatoes once, then keeping them clear of weeds.

My motto in gardening is: "Use the very best of seed." I always send to some reputed seed house, if I haven't got the very finest specimens of my own to save from.

W. A. West, Livonia, Missouri.

\section{DOUBLE CROPS HIS LAND.}

From A. S. Christenson, Dodge Center, Minnesota.

Our garden is for the family only so I cannot tell about the value except that it is more than half of our living; and to have vegetables fresh from the garden is one of the good things of this life that I would not do without for quite a sum.

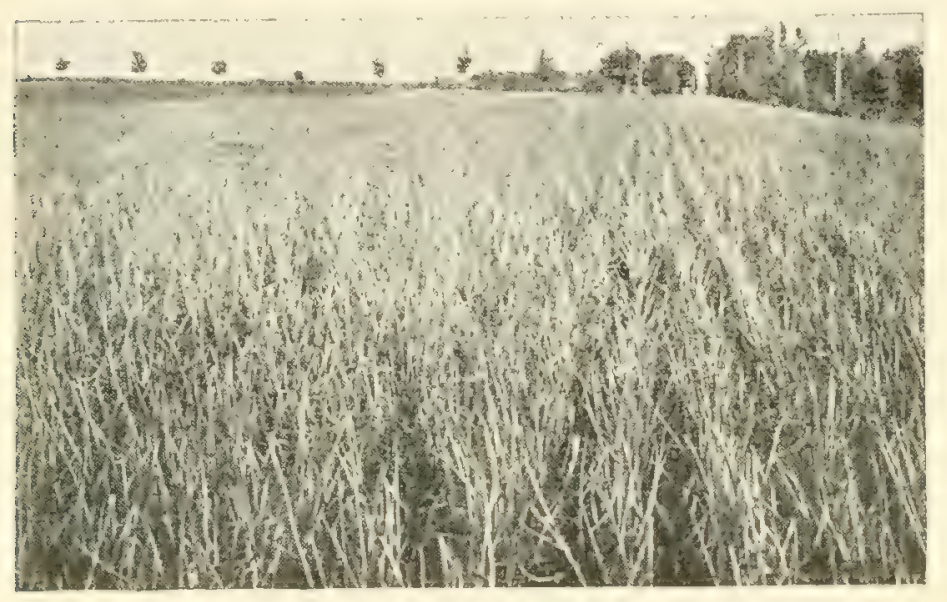

6 Acres of Onions that made $\$ 450.00$ per Acre

The early peas, spinach, turnips, and early corn all come off the land before the squash need the room, and so throughout the whole garden. I sow early radishes very thinly in the rows of peas and get a crop before the peas get large enough to interfere with their growth, and later the peas come off and the ground is used by the squash, making three crops in one year from the same land. Different plantings of lettuce, radishes, and spinach are made between the later vegetables so as to have them throughout their seasons. Within four inches of my early beets I planted a row of climbing snap beans, and now we are having plenty of these beans, and have gotten a crop of beets from the same row, and I cannot see but what the beets were just as good as they were planted without the beans growing at their side.

I am enclosing a postal of a freld of onions of which I have 6 acres; note the luxuriant growith of tops.

I keep the ground free from weeds all season. I try to cultivate after every rain, and if it is a dry time as we had last, and this season, I cultivate about once a week anyway.

I never plant cabbage more than one year on the same land, and the same with potatoes, but onions I like to grow on the same land several years in succession for it improves if well kept.

One of the most important things in a good garden is the getting of good seed. Your seeds were good enough for the most critical, and merit a larger order from me next season.

A. S. Christenson, Dodge Center, Minnesota.

\section{A KANSAS GIRL AND HER GARDEN.}

From Miss Glenna M. Jordan, Peabody, Kansas.

I am the only one that raised any garden this year, and my friends said I raised the finest garden in Marion County, Kansas. All my friends' gardens burned up. I am very proud of my garden this year; tended it all by myself. You can see I am the busiest one in Kansas, and am busy all the time, have plenty to do. I take care of 300 little chickens beside the garden and take eare of my hog.

We didn't have any rain in June, and it looked like my garden would all burn up, but $I$ and William carried water to the garden all during that hot spell. It was 112 degrees in the shade. We carried water right along to the garden till we got rain.

Miss Glenna M. Jordan, Pcabody, Kansas. 


\section{$\$ 150.10$ FROM 281/2 SQUARE RODS.}

From Roy Steward, Horton, Kansas.

We started hauling to market April 18th, and have not missed having goods to supply our three trips a week run all through this dry season. The early bunch beets were just fine. We had the Detroit Dark Red, and they came nearer being drought resistent than anything else we had. Our early beans made fine bushes and bloomed a great deal, but it was too dry for them to set, so they were a failure.

The early cabbage, we had a fine prospect, but it only made onehalf pound to two pounds to the head. They sold here at $4 c$ per lb. at wholesale which helped out some. I bought some of your Surehead late cabbage seed and followed the plans laid out in the

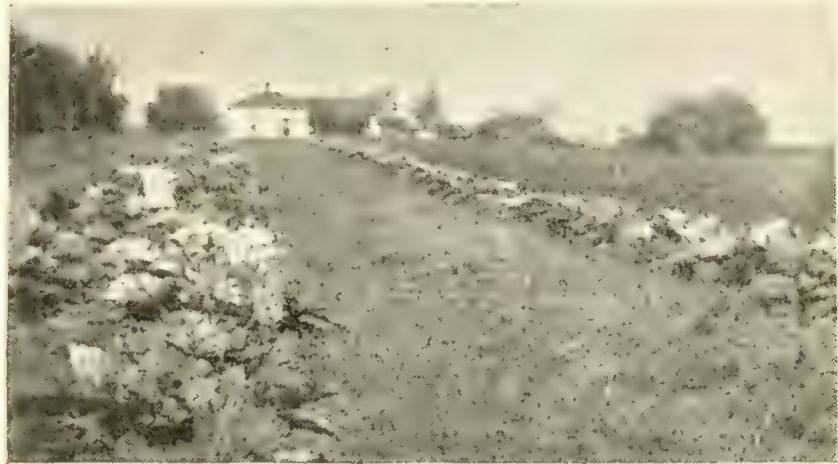

A Garden of less than fifty square rods that yielded $\$ 263.65$ or at threrate of about $\$ 850.00$ per acre.

catalog. Just dropped the seed in hills and then thinned to a stand. They had an awful summer, but those little plants went through it all and never even wilted. We just kept the

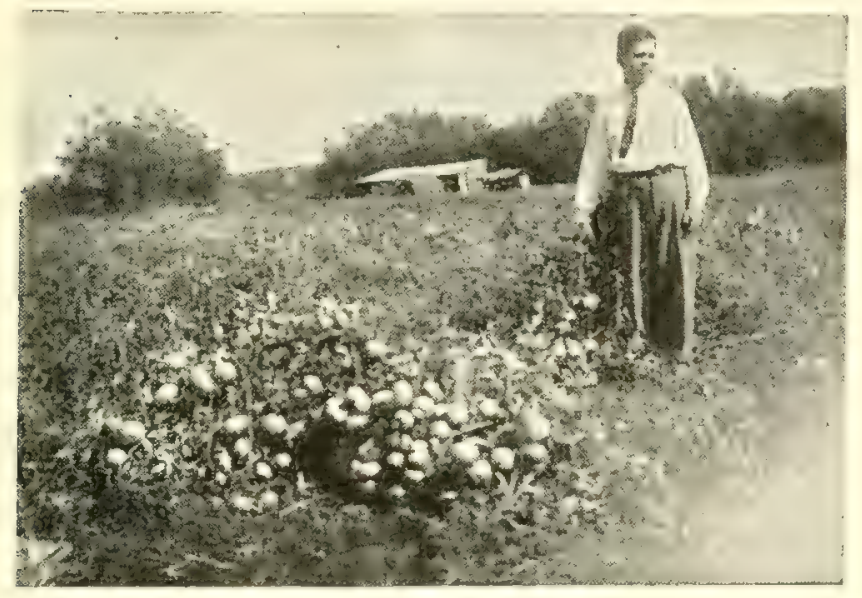

A Vine of Early June Tomato lifted to show the Fruit. Dic you ever see its equal? weeds out and cultivated to keep the ground moist and when we got the late rains they started. We are cutting them now, and there are just lots of them that weigh from five to eight pounds per head, at 3c per lb. looks good to me. People around here that transplanted their cabbage don't have much. I will send you a snap shot of this cabbage patch. We have never watered or sprinkled anything, we depended entirely on thorough cultivation.

In all our gardening we never had such tomatoes. We have a plot of $281 / 2$ square rods. On this, we grew radishes and lettuce in the spring. Then we manured and plowed deep and set the tomatoes. They grew well through all the dry weather until the late rains arrived, and then they set on fruit in a way that paid us well for all the trouble we had. The radishes sold for $\$ 42.05$ and the lettuce $\$ 22.80$. We have sold $\$ 95.25$ from this small field of tomatoes, which makes this piece of land $281 / 2$ square rods yield $\$ 150.10$ in a year like 1911 , and that without even a sprinkler. There is still a lot of green tomaloes to be marketed from this plot and we have something over a thousand nice ones wrapped in paper and crated for late market, say Thanksgiving and Christmas. We used out of the plot for home use also.

The total area of the garden is $493 / 4$ square rods. The total receipts up to date are $\$ 263.55$. This is at the rate of $\$ 847.52$ per

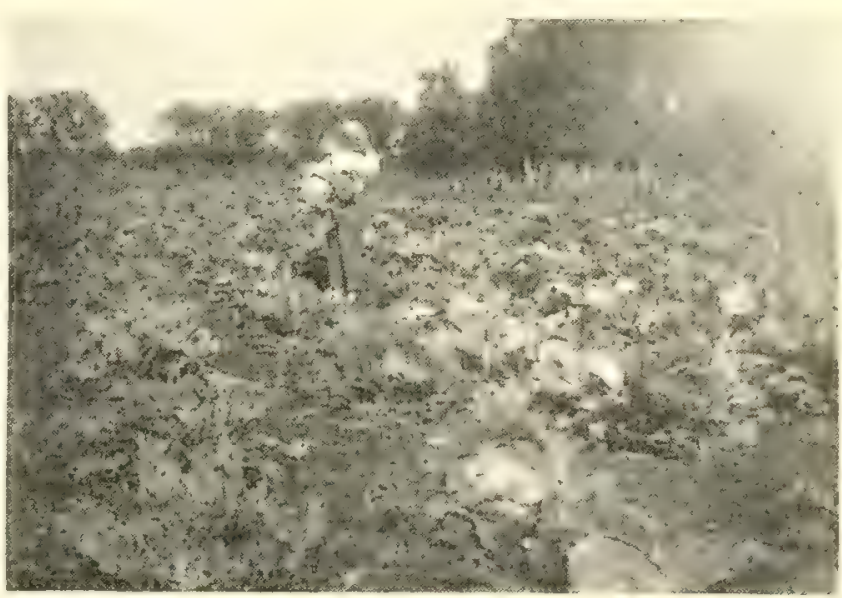

Surehead Cabbage in a Dry Season in Kansas 
acre with the season against our work. I am practically a boy, yet I have had six years experience in gardening and I love the work. Every year I learn many new things. The work is done entirely by myself and wife and our three year old girl, whom we think is one of the main spokes in this wheel.

Roy Steward, Horton, Kansas.

\section{BEST GARDEN HE EVER HAD.}

Frank 1. Yerger, Sigourney, Iowa.

My garden was the best I ever had. I had never planted your seeds before, but will again. I do not plant for the market but for home use and the pleasure to be got out of it.

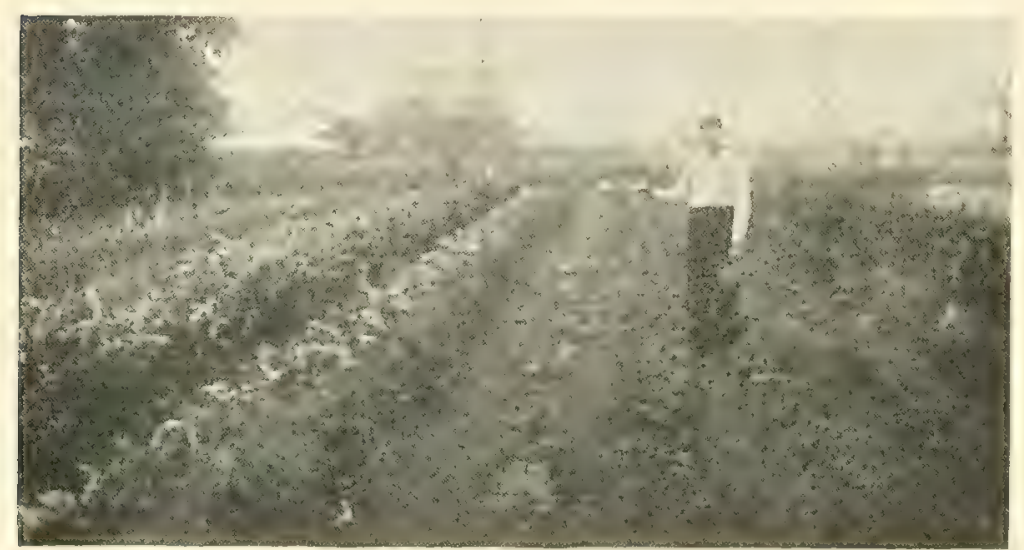

A good garden. Notice the straight rows.

My garden is about 110 feet square. I plant all my stuff in rows by a chalk line so as to get them straight. I tend, for the most part, with a wheel hoe. I plant all the extra early stuff together, so after it is gone I can use the ground again.

For main crop, I plant the sorts I know will do well in my section, and lest the new sorts in a small way. Frequent cultivation is * most important thing. You can go over it three times quicker and better before the weeds get a start than you can once after they do.

Frank I. Yerger, Sigourney, Iowa.

\section{BUSHEL OF CUCUMBERS A WEEK ALL SUMMER FROM TWO PACKETS}

From Henry LoI, Floyd KnOBS, Ind.

From two packets of cucumber seed bought of you, the Golialh and Emerald, I marketed one bushel of cucumbers per week since the first of July. They are fine bearers. These varieties of cucumbers sold for 5 cents apiece.

The summer was one of the driest that I can recollect, but my corn and fall crops look fine. All the early grain was ruined. Wheat, rye and oats were very short. The best thing in dry weather is good frequent cultivation.

I find berries the most profitable crop for this part of the country. Of course other places it may not be.

Henry Loi, Floyd Knobs, Ind.

\section{SOUTH DAKOTA WAS HIT HARD BY DROUTH.}

From Joseph Pfoff, Glenham, South Dakota.

I plant most of my garden in drills except the cabbage. I plant that so I can plow it both ways, and the tomatoes I plant diamond shape. I planted 2,500 and that was my money maker. I also planted one acre of carrots and have not a one, and one acre of beets and have about a dozen. I will just have a few melons off of one acre. I planted them in drills, and when out of danger, I thinned them out. Planled an acre of muskmelons and cucumbers and got a few. Planted two acres of pumpkins and squashes, and will not get a one. Will get a few beans off of an acre. The seeds were all good, but the dry weather was to blame. Planted about 2,000 cabbages and will probably get two. The seed was zood and all came up, but just as quick as they would get about one inch high, they would dry up.

I have worked hard this summer and haven't got anything to show for my work, and I don't see what people will get seed with next spring. Crops were a total failure out here. I bought a lot of seed from the stores when it got late but it did me no good. I will have all new seeds next spring. You have no idea what it is to be in a shape as we are. Nothing at all, no feed, no wheat, no hay.

Joseph Pfoff, Glenham, South Dakota. 


\section{WATERMELONS FROM ONE PACKET OF SEED.}

From Karl E. Sheldon,

Mazerpa, Minnesota.

My garden consisted of one-half acre of ground which was very rich. I plowed it in July, 1910, and then worked it every week until last November. This spring I plowed and harrowed the ground three times before planting. Sowed about one-sixth of an acre (one-third of the garden) to onion seed, using Field's Red Globe Weathersfield seed. The onions started to come up and the cut worms took almost every one, so I plowed them under and sowed it again to the same seed.

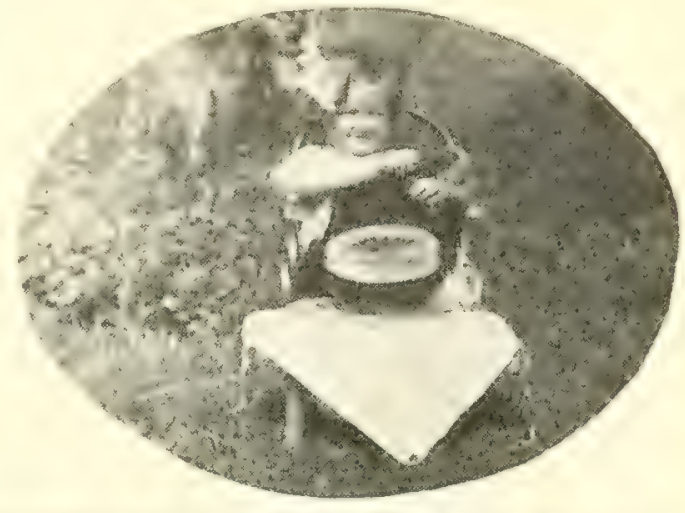

Miss Wanda Sheldon feeding her rag doll "Mammy", some of Field's Princess Melon

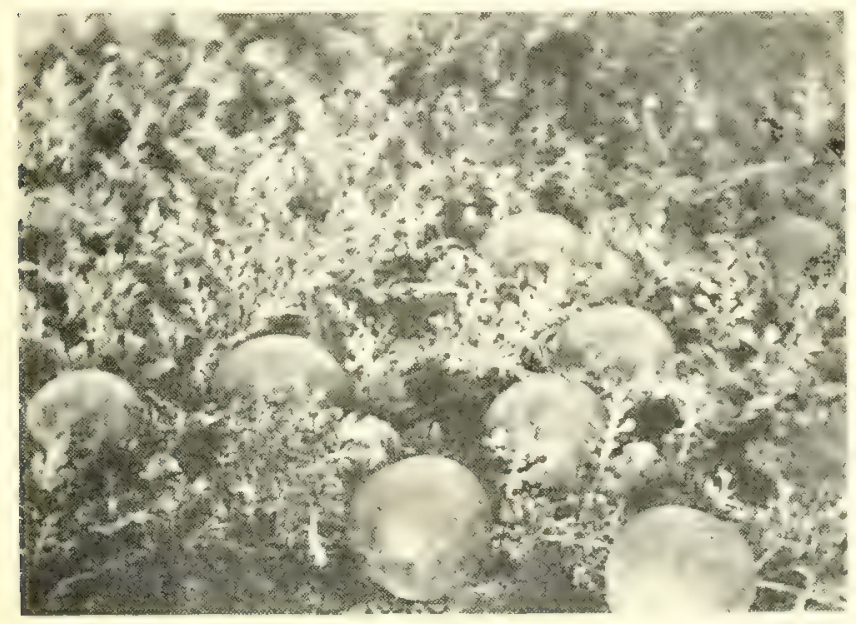

Corner of a Patch of Field's Princess Melons in Minnesota. Over 60 Melons from 6 Hills

loaded with peppers. Sowed two rows of carrots from one package of seed and have all of $2 \frac{1}{2}$ bushels.

The Princess watermelon is the best melon I ever saw. From one package of seed I raised over fifty fine melons. You could almost see them grow and they are so sweet when ripe. I sold twenty head of cabbage for $3 c$ per $l b$, and received $\$ 3.00$ for them.

I enclose a few kodak views. I am a beginner with the camera and they aren't very good, but I hope to see them in that book.

\section{KARL E. SHELDON,}

\section{Mazeppa, Minnesola.}

Harvested 40 bushels of fine onions, sold some for $\$ 1.00$ per bushel. Planted the cabbage seed in hills the dislance I wanted them to grow, about two feet each way, and thinned out to about one plant in each hill. The heads grew so fast that about fifty of them cracked open, but I find that if a person will pull the roots loose, that is lift the cabbage a little, it won't grow so fast and so it won't crack open.

I had 35c worth of pepper seed and sold ten dozen of the Ruby King peppers, green, for $20 c^{\circ}$ per doz. Pulled the pepper plants last week and hung them in the cellar. They are just

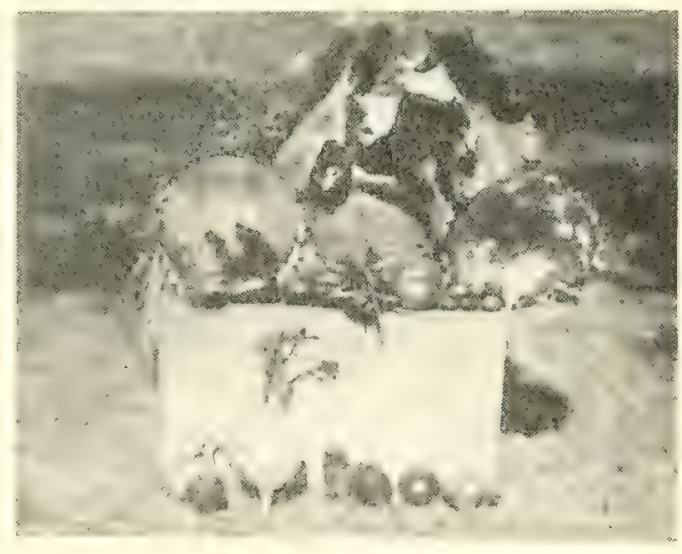

Products of a Mincesota Garden. Corn Belt Cabbage, weight 10 lbs., Mammoth Russian Sunflower, Ruby King and Cavenne Peppers. Early June Tomatces and Kohl Rabi

\section{\$30.00 FROM ONE-EIGHTH ACRE IN NORTH CAROLINA.}

From J. E. Parker, Parker, North Carolina.

The first consideration for a successful garden is fertility of the soil. Therefore it is necessary that a fertilizer be used. I find that well rotted stable manure (also chicken manure if available) to be the best fertilizer if it is turned under deeply. 
I use approximately one-eighth of an acre for a garden, and can only give an estimate of the value of the products, as all was or will be used for family purposes, but a fair estimate of the value of all products raised world be at least $\$ 30.00$.

I. E. PARKer, Parker, Norlh Carolina.

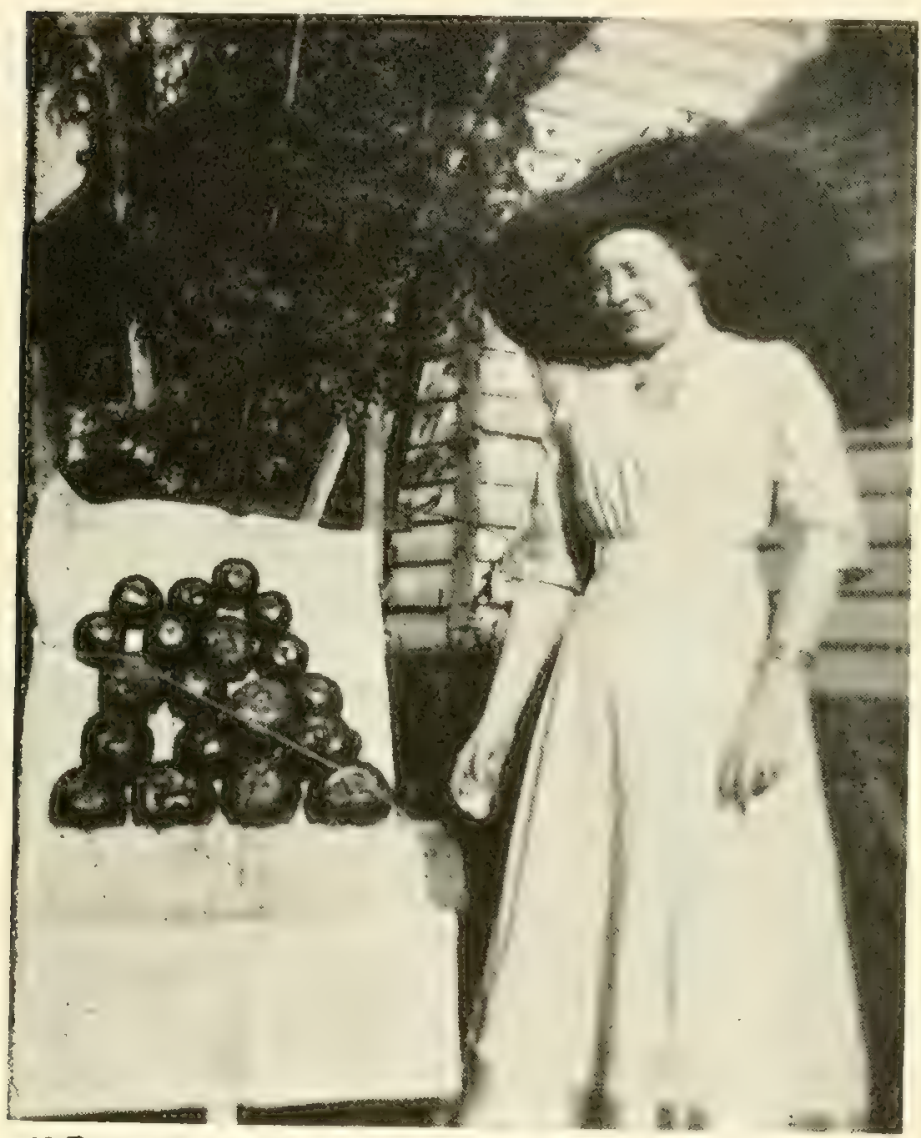

19 Tomatoes weighing $34 \mathrm{lbs}$, at a single picking from one vine

\section{RIPE TOMATOES}

JULY 4 TH.

FROM S. M. NEWLON,

Salem, West Virginia.

The drouth was so against us that we practically failed with a great many of our vegetables. Never the less, the Early June tomato, that I call the Preacher's tomato, gave us nice ripe fruit the fourth of July, and two of the vines are still ripening tomatoes yet, October 30th. They are all right and by the far the earliest tomato I have ever grown. We also grew fifty pounds of the Shenandoah that was on a frame. We are sending photos of the vines, also photos of some of the fruit off of the same vine. Nineteen of them weighed $34 \mathrm{lbs}$.

We find it best to put at least half of our tomato vines in a frame Iwo feet square with slats nailed to four small stakes. We sell early tomatoes at high prices and can the later ones with a Modern Canner. We put up one thousand, three pound cans of tomatoes and sold $\$ 85.00$ worth of early tomatoes from one thousand plants. We call this a half crop on account of dry weather.

\section{S. M. NEWLON,}

Salem, W. Va.

\section{CONTINUOUS CROPPING AND CULTIVATION.}

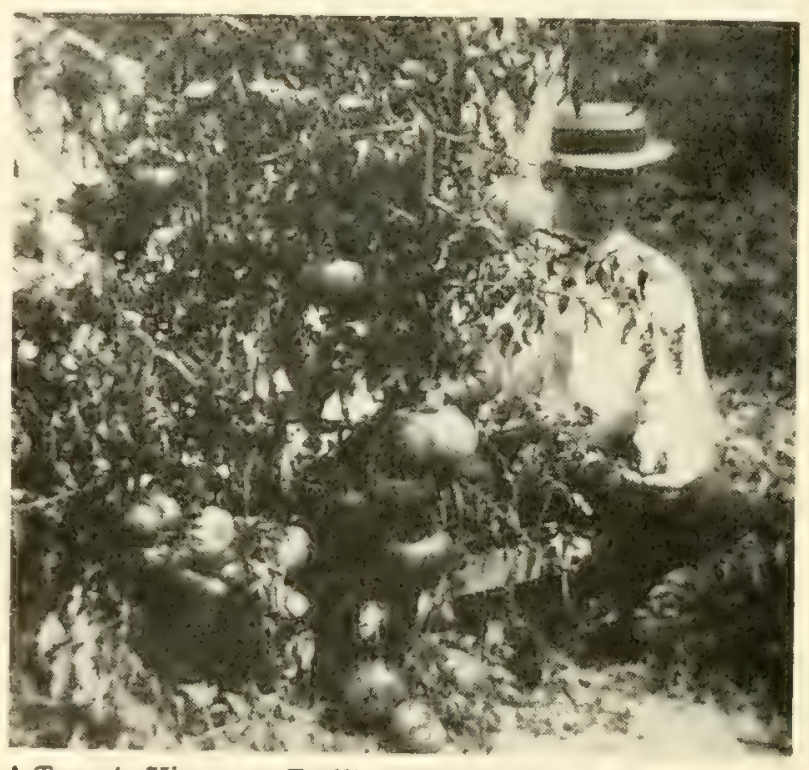

A Tomato Vine on a Trellis. It Yielded in all over $50 \mathrm{lbs}$.

From Miss Eva M. CARTER,

Tonganoxie, Kansas.

My garden is only $16 \times 33$ feet. It has an airy, sunny location with the overhanging boughs of a fruit tree close oulside the fence giving the needed shade for the letluce beds. 
The soil is a rich black loam. Had the weather continued seasonable, I think my garden would have been a decided success.

In planting, early mustard was replaced by Field's Daisy muskmelon, earliest lelluce, and onions by cucumbers and Field's Early June tomatoes. Continuous cropping and cultivation keeps weeds in subjection and conserves moisture.

Miss Eva M. Carter, Tonganoxic, Kansas.

\section{A DAKOTA GARDEN.}

From Mrs. J. R. McMahon, Stamford, South Dakota.

We are in the new part of Dakota on our claim so of course our garden will not compare with those raised in older states. I have a garden plow and use the weeder that keeps the ground mellow and destroys the weeds at the same time.

I like to start everything that has to be transplanted either in the house or hot-bed so 10 have them ready to set in the ground just as soon as danger of frost is past. I have about one acre fenced with woven wire for garden and fruit.

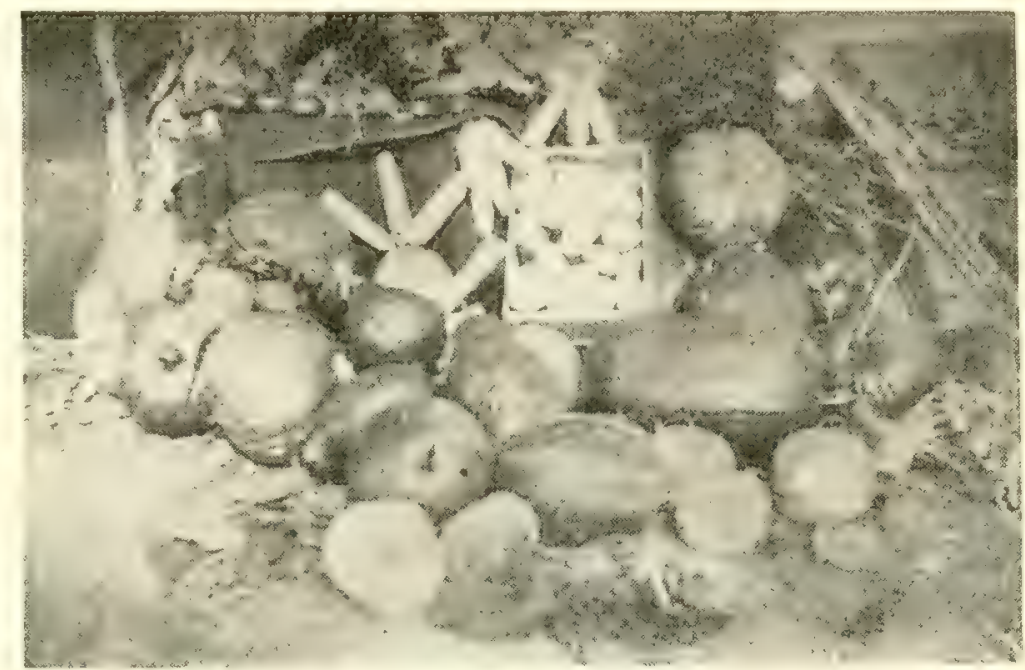

Vtgetables Grown First Year from Sod in S. Dak.

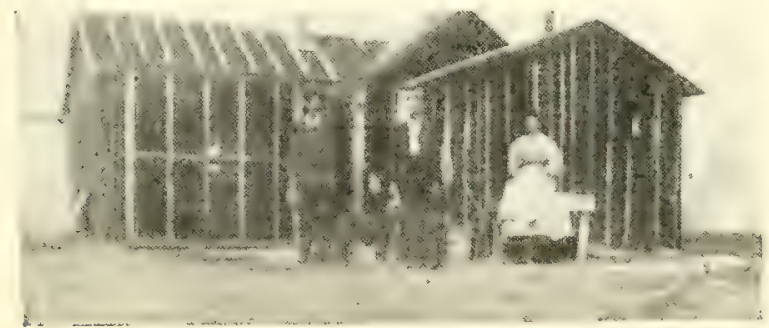

A Home in the New Country of S. Dak.

The peas and tomatoes yielded the best this year. No rain on my garden from the first of May until the 6th of August, but for all that we had plenty of peas, radishes and lettuce. Other vegetables were not so plenty. Tomatoes were late but we had bushels of them. As for melons, this is surely their home. A good yield and of extra fine flavor.

$$
\text { Mrs. J. R. McMahon, }
$$
Slamford, S. D.

\section{FIVE BUSHELS OF TOMATOES FROM 50 HILLS.}

\section{From Henry Cole, Hart, Michigan.}

I planted watermelons, muskmelons, tomatoes, cabbage, peanuts, popcorn and radishes. Planted two varieties of watermelons, Halbert Honey and Princess, and also planted the Hackensack muskmelon. I planted about eight hills of the Princess and about five came up, and two of them washed out. I had three hills and about a dozen good size watermelons. I did not sell any of them but sold some of the Halbert Honey melons. I had about eighteen hills of them and sold twenty melons at ten cents each. The Princess walermelon is one of the best watermelons that I have ever tasted.

I had about fifty hills of tomatoes, and sold five bushel at $50 \mathrm{c}$ a bushel, and the rest of them I gave to my mother. I planted my seed in a box first, and when they got about four or five inches high, I dug them out of the box and set them out about three feet apart. I planted my cabbage in a row in the garden and when they got about three inches high, I thinned them out to about a good foot and a half apart. I had about a hundred head and sold about fifty head for \$1.50. I had some heads that were over twenty inches across.

I planted about a dozen rows of popcorn about four rods long and got six bushels. I sold 
five bushel at $50 \mathrm{c}$ a bushel. I planted a row of radishes about four rods long. I took a few bunckes to town and got $50 \mathrm{c}$ for them. I had as high as a hundred peanuts on a hill. I pulled them and piled them loose in the field. I left them lay too long for some of them turned black. It rained every day so they couldn't get dry, and finally the sun came out hol and I think that is what made them turn black.

I have got a few potatoes, about twenty-five bushel, I guess. I haven't sold them yet so don't know how much I will get out of them. I made $\$ 9.00$ off from my garden besides my potatoes. I would like to send some pictures of my garden but it would cost quite a lot. The nearest place where there is a camera is ten miles.

Henry Cole, Hart, Michigan.

\section{RAISES MOSTLY PEAS, TOMATOES AND SWEET CORN.}

From E. G. Knapp, Oswego, New York.

I am sending you a photograph of my Giant Sugar Beets. Now those beets, I had to plant three times before I got them to grow, but I got 156 bushels on one-fourth acre. My

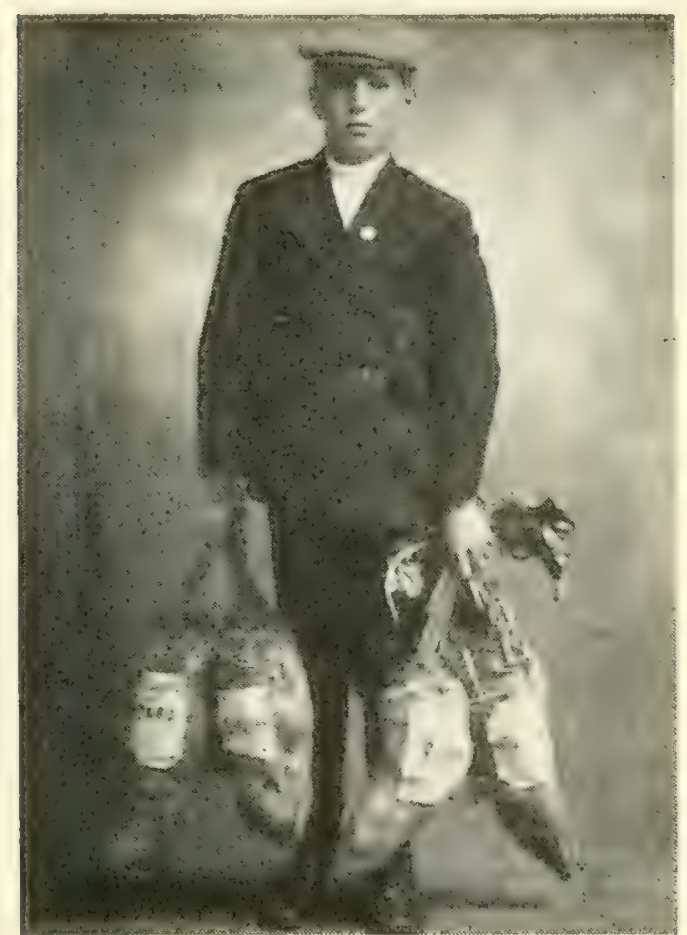

Giant Fecding Sugar Brets. 156 bu. on 1-4 Acre.

from you paid well. At the start I got as high as $\$ 6.00$ per bushel.

I plant my peas $2 \frac{1}{2}$ feet apart in drills. I cultivate them well and hoe them once. Sometimes I sow corn for fodder on the same ground as soon as the peas are done.

I have about two acres of garden. I make about $\$ 300.00$, but you have got to be moving right along. You have got to get up at four oclock in the forenoon.

E. G. Knapp, Oswego, New York, R. R. No. 6. I had to get a piclue of him and the beets taken. I put them $2 \frac{1}{2}$ feet apart each. I planted them in hills same as corn. Never leave any more than four in a hill. Three is better. It takes a little longer to plant them that way, but you make up that when you go to hoe and weed them.

What I raise is mosily peas, tomatoes and sweet corn. Now, the best paying crop for me was peas. As bad as the summer was, I made from that peck of peas I got from you $\$ 18.00$. Those Early June tomatoes I got

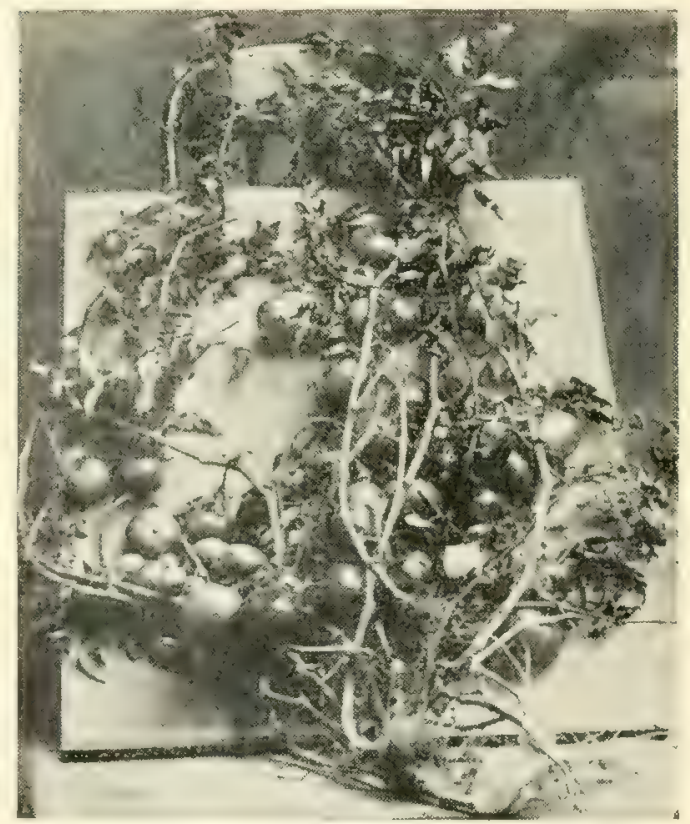

50 Early June Tomatoes on One Vine. litle boy was so well pleased with them that

\section{A SCHEME FOR DOUBLE PLANTING.}

From O. Burton, (Address Lost).

In planting peas you can always plant parsnips or carrots in the same row, as parsnips are slow 10 germinate. They will be but well started when the peas are ripe. Pull up the peas and you have saved a lot of hard weeding and will do better than if planted alone. In planting beans, I plant beets in sare row with the same results as in planting parsnips with early peas.

O. Burton, (Address Lost). 


\section{\$152.58 FROM A QUARTER OF AN ACRE.}

From J. Wesley Criffin, Warsaw, Ky.

I live in the suburbs of the litlle town of Warsaw, Ky., with a porylation of about

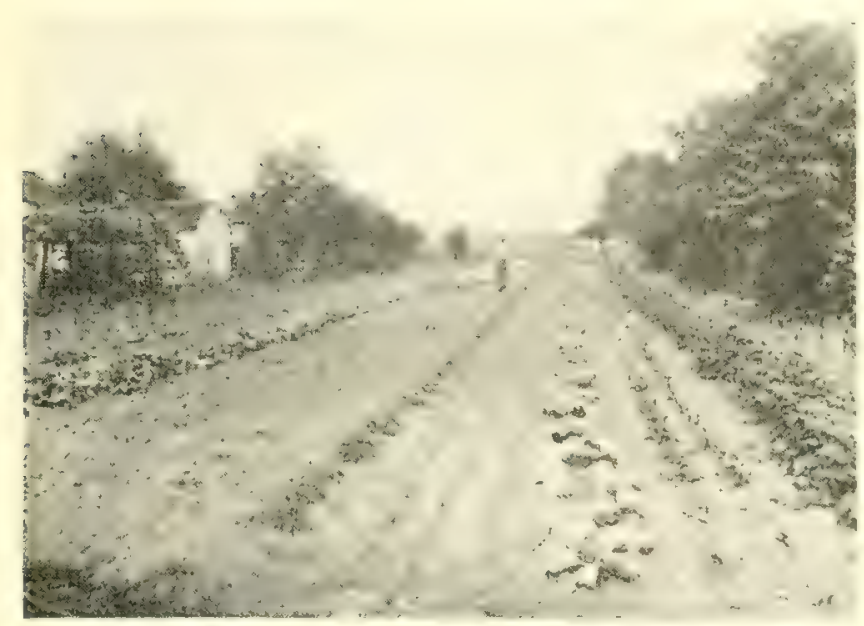

A Quarter-acre Garden well Care? for

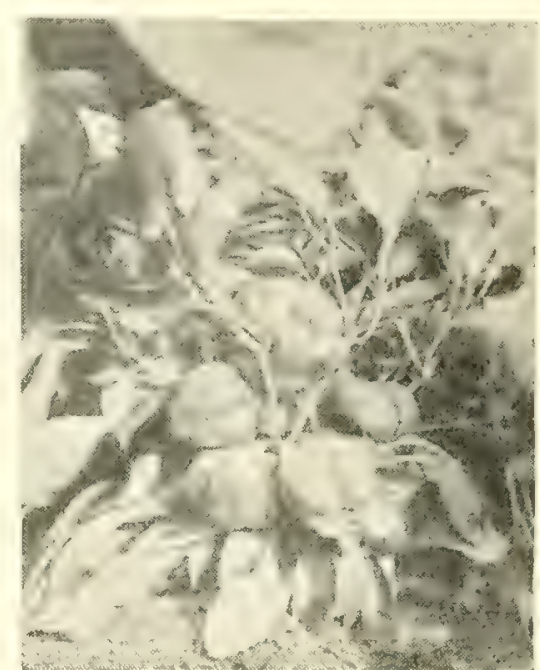

Grow $\mathrm{n}$ in a vacant lot garden

1,000 inhabitants. My garden was on a vacant lot, $60 \times 180 \mathrm{feet}$, a little less than a quarter

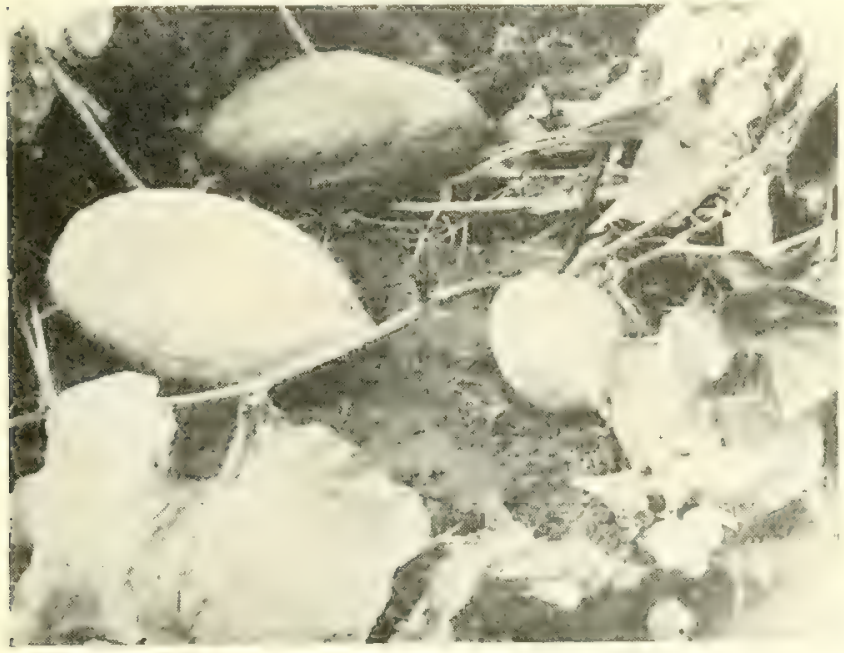

Golden Hubbard Squash grown on a Vacant Lot. of an acre. The south side was so shaded that at least ten feet wide, the entire length of the lot, was practically worthless as a garden. I am a carpenter and follow carpentering as a vocation. The grealer part of the work done in this garden was after and before working hours. My object was to devole two hours every day in producing this garden.

I generally raise a few sweet potato plants each season, but never sufficient to fill all orders. The plant part of the business is a very profitable one. Especially where one is located so that he can make a good display with the growing plants. I made my hot-beds next

to the street, and my ficld grown plants, such as cabbage, tomatoes, peppers and celery, were in rows where any one passing could see them. I did not have to do any advertising through the press to get customers, everybody that saw the garden told everybody they met about Griffin's Garden. It was the talk of the town. Nothing out of the way, but out of the ordinary around Warsaw.

In regard to the way I cultivated my garden, I aimed to keep the soil loose and mellow at all times. This I did with a s'arp toothed garden rake. After each plowing with the wheel garden

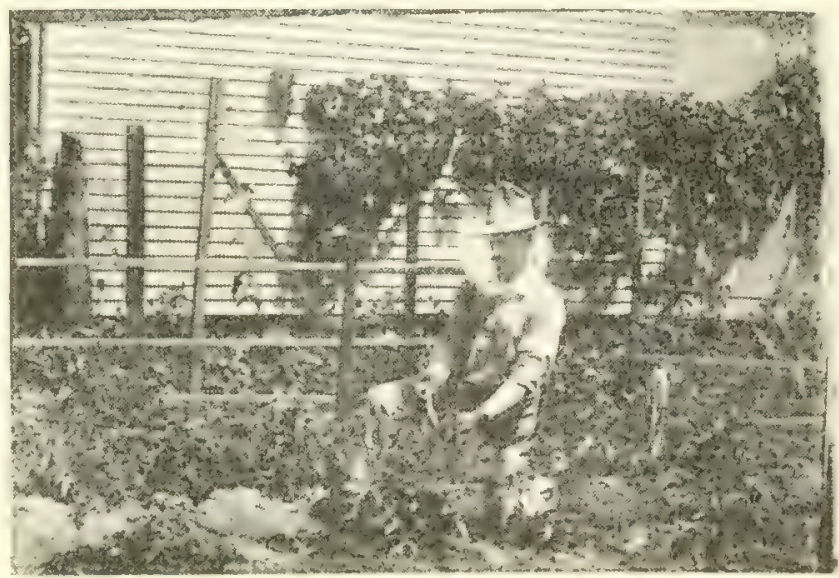

Staking up Tomatoes 


\section{THE BOOK OF A THOUSAND GARDENS}

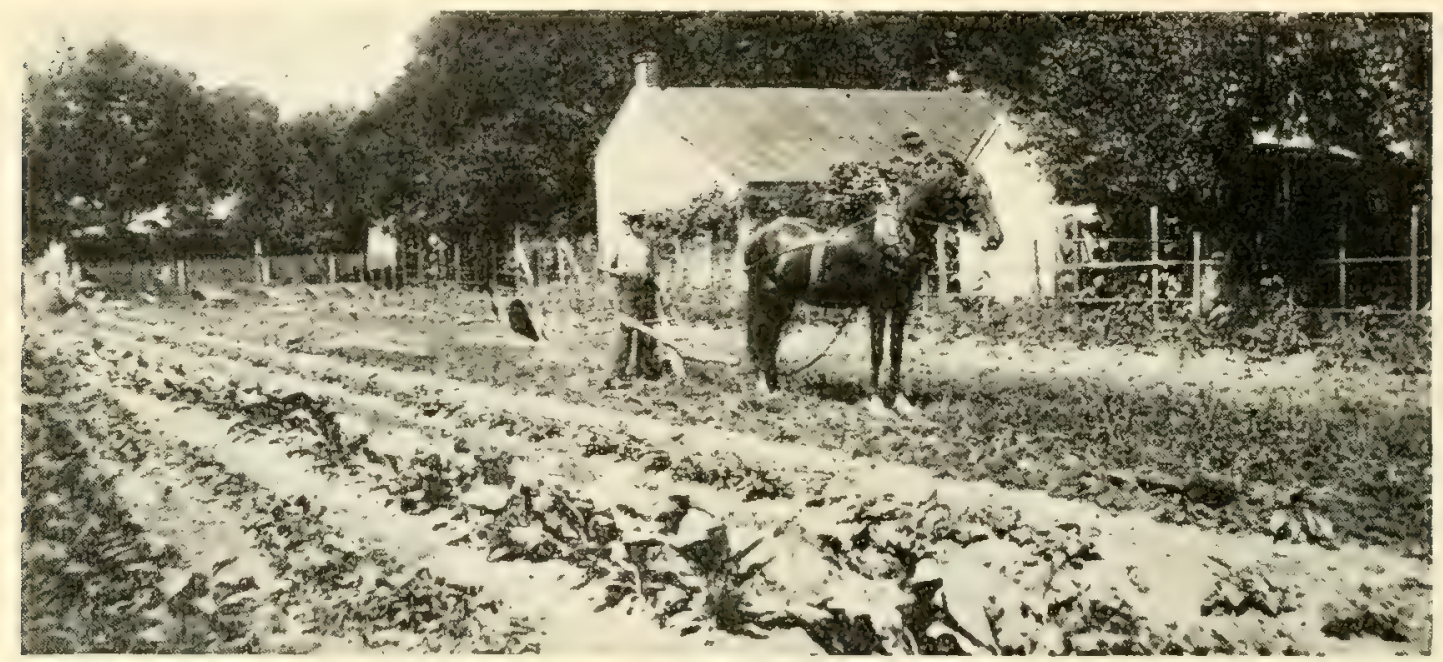

plow I would walk backward andrake the soil level all around theplants and in the middles beiween the rows. By having the rows perfectly straight, and having them at regular distances. from each other, it was just fun to work in the garden. I mulched the tomatoes with the manure used in the hot-beds for starting the early plants.

Taking it in all, with careful cultivationand close attention to details, I have done very well.

Here is what I made from the garden:

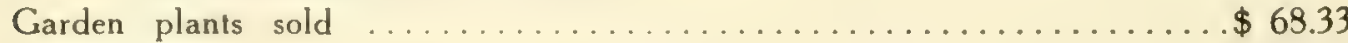

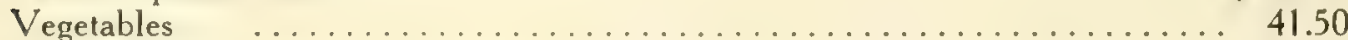

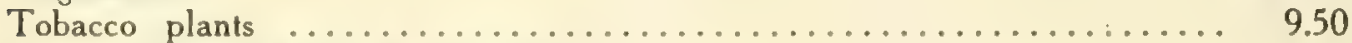

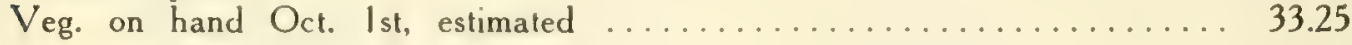

Total from the one-fourth acre ................. \$152.58

J. Wesley Griffin, Warsan, Ky.

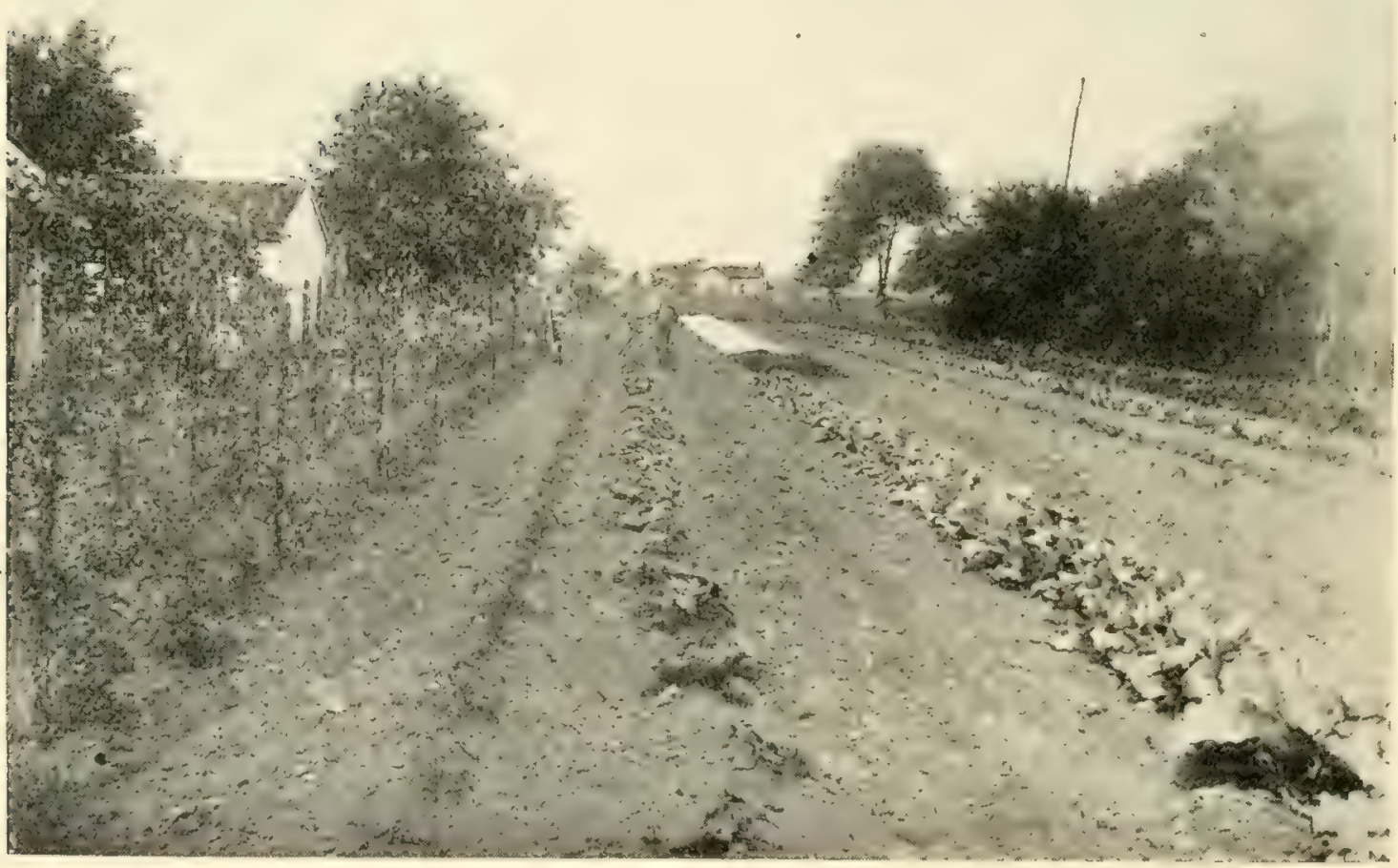

Work that pays 


\section{\$97.00 WORTH FROM A GARDEN 100×63 FEET.}

From M. A. Reinhart, Montague, Michigan.

My garden spot is $100 \times 63$ feet. I sold in all $\$ 41.00$ worth, and consumed ourselves or gave away in all about $\$ 16.00$ worth. I have still unharvested the following: Cabbage, 80 heads, Cauliflower 30, Carrots 30 feet, Parsnips 30 . feet, Parsley 30 feet, Beets 30 feet, Cale 50 plants, Savoy 20 plants, Turnips 90 feet, Beans 60 feet, Leek 100 30 feet. And plenty of tomatoes plants, Salsify 60 feet, Swiss Chard in all stages. Value of all this easily $\$ 40.00$.

My garden was divided by a path three feet wide from house to harn, making all my rows 30 feet long. On one side of the path I planted with the following plants: cabbage 110 , cauliflower 50 , peppers 16 , kale 50 , savoy 20 , tomaloes,

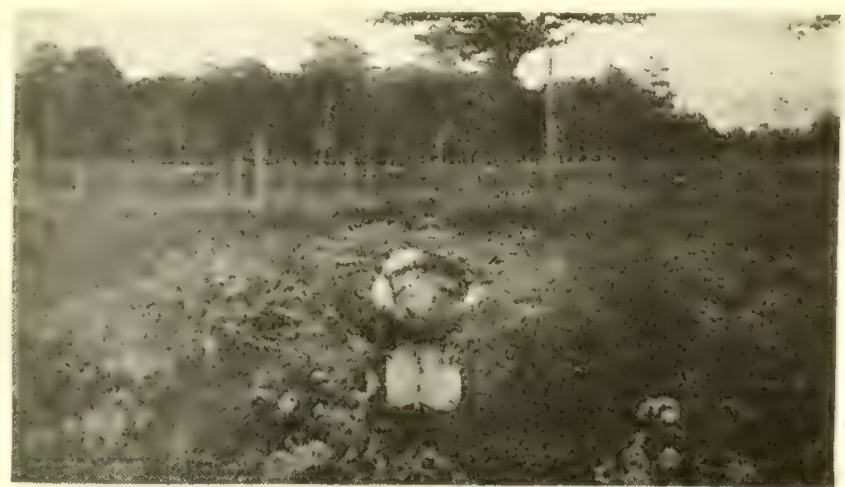

Most more cabbage than boy red, 110 , pear 40 , lettuce 300 , egg plants 18 , summer squash 8,3 rows carrots, 1 row parsnips, 1 onions, 1 parsley and Dill, 2 salsify, 3 Swiss Chard, 9 beans, 1 Lima, 20 peas, 10 sweet corn, 5 beets, 1 sage, 3 turnips. In hills, watermelons 5 hills, vine peach 10, cucumbers 12, 6 rows of radish and 100 plants of leek, 4 rows of rutabaga. Flowers along the road side, 100 feet four o'clocks, one bed of cannas, 100 gladiolus. One side was edged with wall flower, petunia, 10 weeks stock nicotina, sunflowers and poppy scattered through the garden. I raised many other flowers but not in this garden lot.

This is how it was done: My plants are planted three feet apart. Between the rows I planted cabbage, yellow tomatoes, and also cauliflower. Early Sugar corn was also

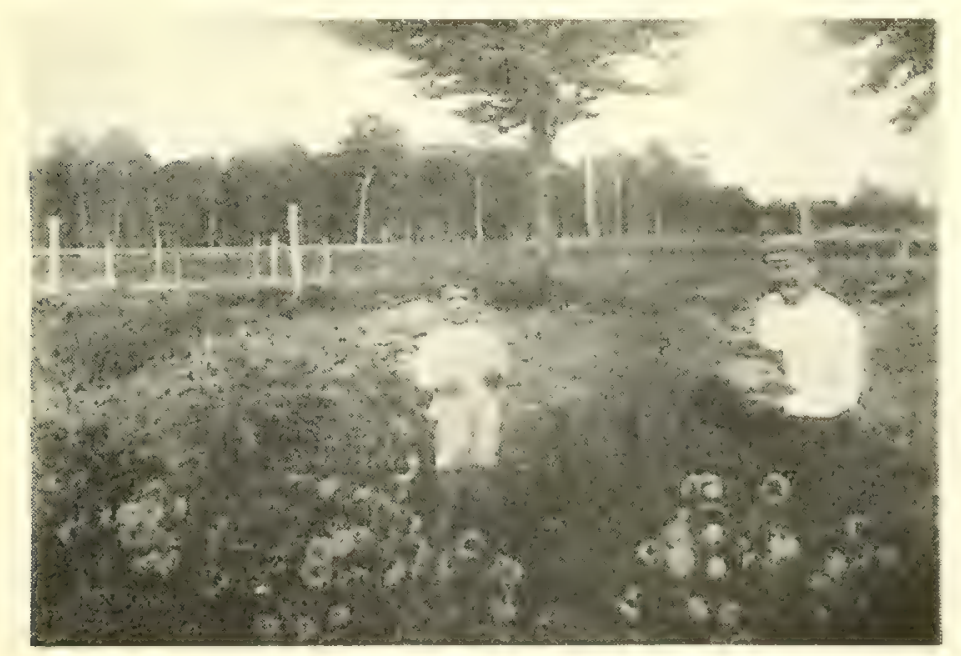

Here we are, proud of our garden planted three feet in drills. between these lettuce, summer squash, vine peach, cucumber. Early beets and carrots were followed by late $\mathrm{cabbage}$, peas and beans. This, I replanted every row that had been harvested, in fact, I never waited except where I followed with beans and peas till the whole row was bare, but as soon as a foot or two of ground was empty I turned it over, mixed in some well rotted manure and put in some plants. Thus at the time of writing, my whole garden is still producing. We are having beans, peas, radishes and lettuce as a second crop.

Here is what I have harvested: Peas ...................... 7 bu. Lettuce ............................. 50 lbs. Tomatoes, red ................700 lbs. Tomatoes, yellow .............. Cucumbers ................. bu Egg Plants ..................... The other things I have no record of, or they are still in the field. I did well with all of these things, being the earliest in the market. My tomato crop was sold before my neighbors had any ripe ones at all, and they paid me best, $\$ 28.34$.
Corn ......................... doz.

Wax Beans ...............60 lbs. Onions ............... bu. Radishes ..............112 bunches Beets .................20 bunches they are still in the field. I did well with M. A. Reinhart, Monlague, Mich. 


\section{THE BOOK OF A THOUSAND GARDENS}

\section{BEANS PAY BEST.}

From Mrs. D. B. Whisler, Creighton, Mo.

I am trying to write you a true story about the success we have had in raising garden. I think we have more profit off of beans, both field beans and bush beans, potatoes, tomatoes,

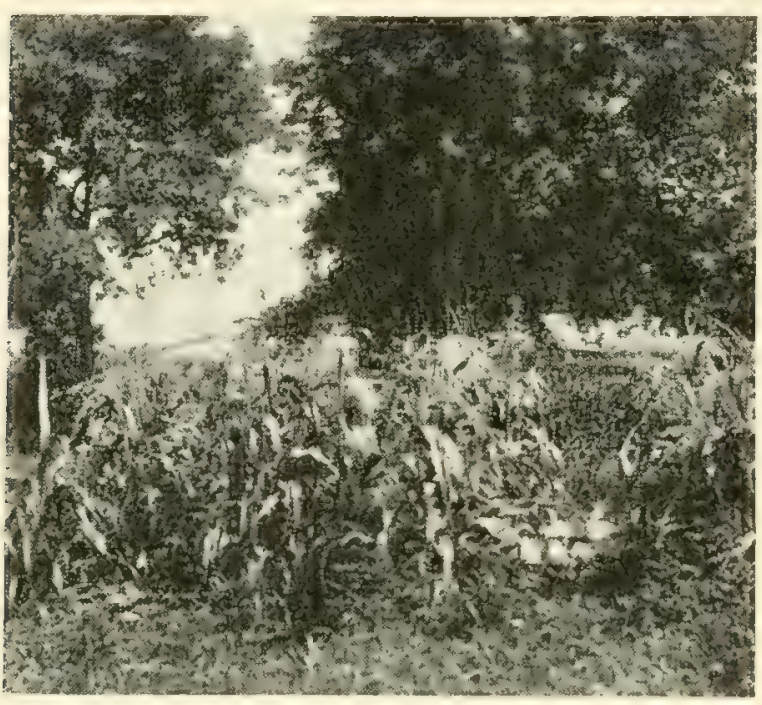

A town lot corn patch cabbage, turnips, and onions than most anything else in the garden seed line.

Now these seeds which I've mentioned above, we scarcely ever have a failure in, especially when we have Field's seed.

The way to grow the best garden is, I think, to select a good, rich patch, then plow it good and deep in the fall and again at planting time. Then with a good garden plow and drill put in your seeds, and as soon as the little plants are large enough to sow right good, we always begin to stir the ground to keep it loose and also keep the little weeds from getting the start of the plants. We always plant as much as an acre, from that to two acres in garden potatoes and sweet corn. We have good luck with sweet corn, also.

Mrs, D. B. Whisler, Creighton, Mo.

\section{WON A PRIZE ON FLOWERS.}

From Etta Gamble, Hume, Missouri.

The melons and cucumbers did fairly well. Raised lots of summer onion sets, and the

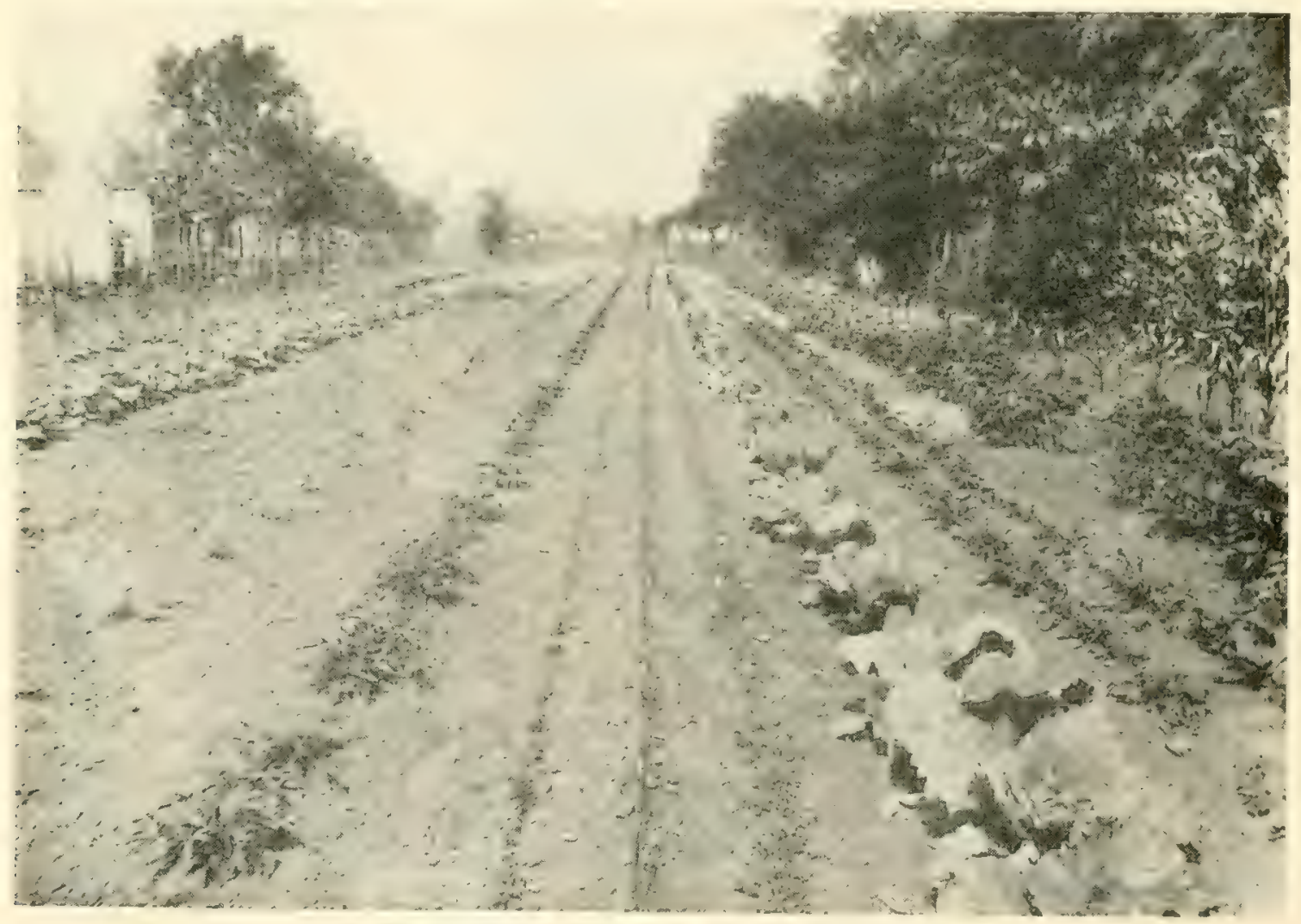

Fine garden of J. Wesley Griffin, Warsaw, $\mathrm{Ky}$. 
early garden, such as radishes, lettuce and onions, did well. Had plenty of tomatoes for my own use, but had none to sell. My flowers did very well. I got the blue ribbon at the stock show on my bouquet of all kinds of garden flowers.

Etta Gamble, Hume, Missouri.

\section{AN INVALID AND HER GARDEN.}

From Mrs. T. J. Gates, Gentry, Ark.

My garden is four rods square. I leave a two foot bed around the fence, and have a walk in this bed I plant to lettuce, mustard, kale, spinach, beets, rhubarb, and next to the edge of the walk I plant a row of radishes, and later I plant a row of peppers next to the fence.

First, I plant 5 rows of onions, 1 of beets, 5 of cabbage, 2 of bunch beans, 1 of Princess watermelons, one-half of muskmelons. I plant zig zag, some large sunflowers to help shade melons to keep them from sunburning; 12 rows of tomatoes, 6 of Early June and six of another variety. There was also 2 rows of sweet corn, 1 of pole beans on side of the fence, and one-half row of cucumbers and turnips.

I had splendid success with growing crops from your seeds. I failed to tell you how I started my tomato plants. I put them in boxes the fourteenth of February in my house among my flowers. When they were four inches high I transplanted them in another box until all danger of frost was past. About the first of May I planted them in my garden.

I am an invalid and my husband is not a stout man, consequently I try to help him to lay up for a rainy day. From three dozen chickens, we have sold over $\$ 100.00$ worth. We have a very poor market for anything we have to sell.

Mrs. T. J. Gates, Gentry, Ark.

\section{SWEETEST MELONS HE EVER HAD.}

From B. F. Beck, Mechanicsburg, Pa.

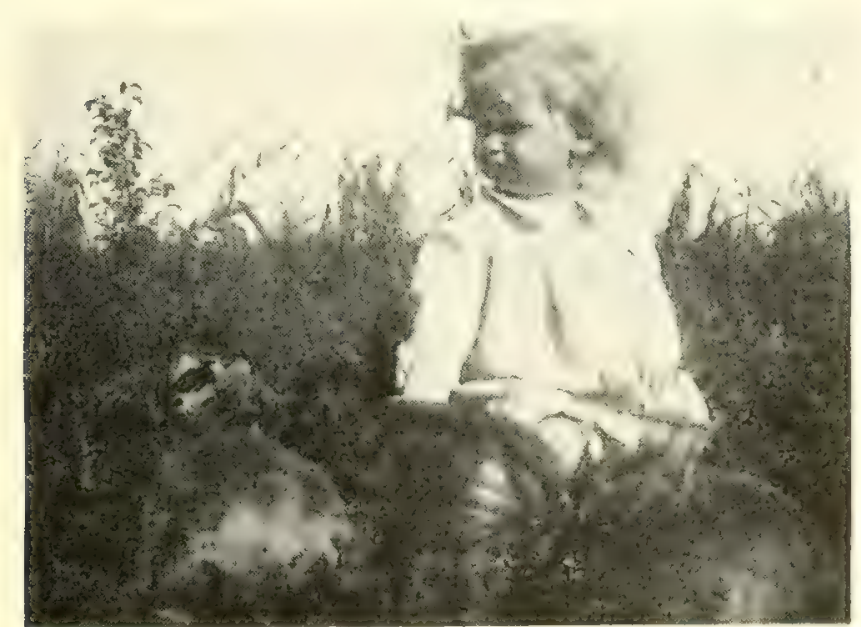

Watermelons bigger than the girl
1 planted my melons on May 6ih and cut the first melon the last of July. In planting, I made a trench about three inches deep and filled it with chicken manure, and made a row like a sweet potato row, and when the vines were about four feet long, I worked in a small hand full of nitrate of soda at each plant. Parties that I treated to melon said they never tasted better ones. They are the sweetest melon I ever tasted. The larger melons were much better than the small ones, being darker red and sweeter. B. F. BECK, Mechanicsburg, $\mathrm{Pa}$. 


\section{THE BOOK OF A THOUSAND GARDENS}

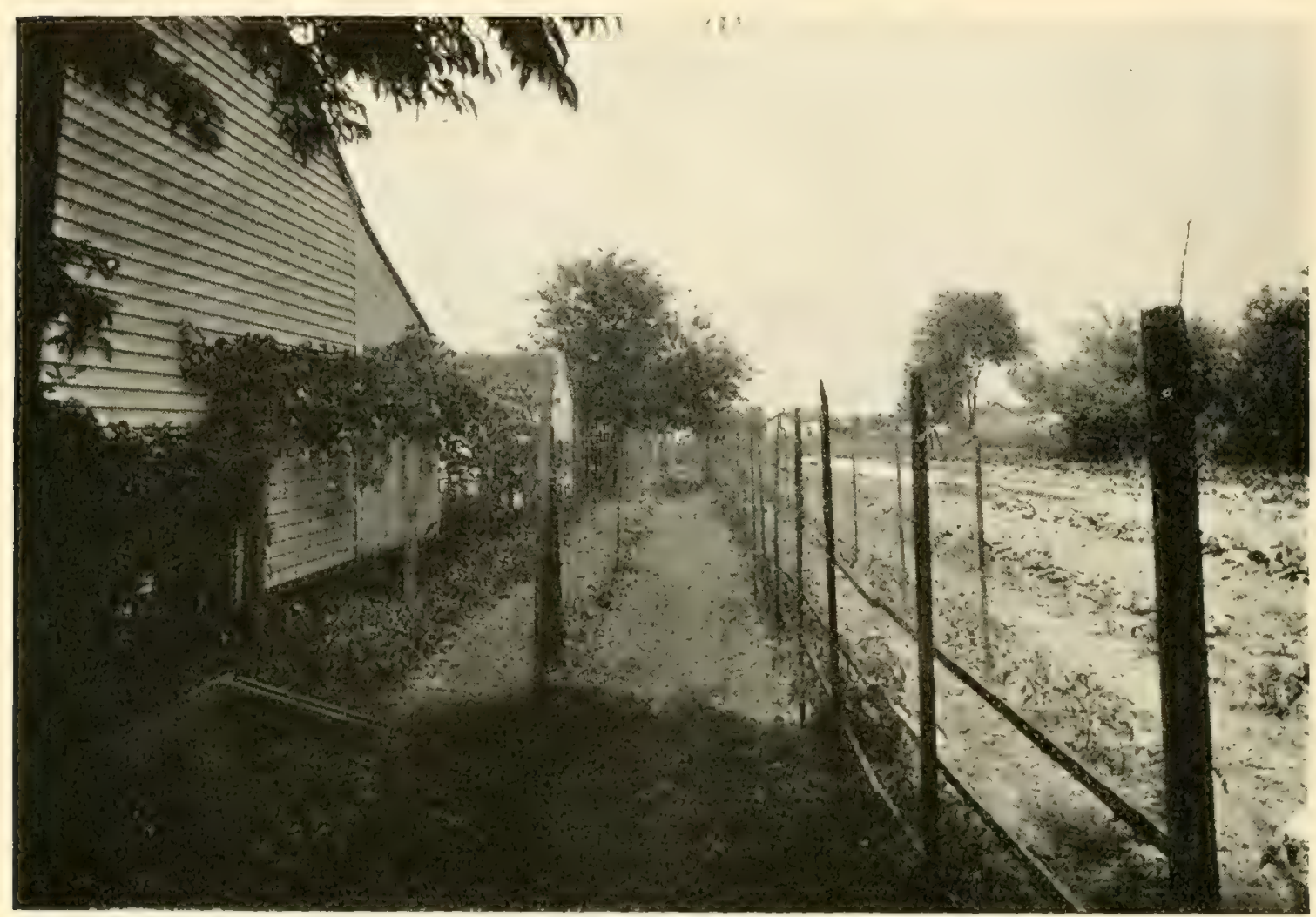

Well utilized ground

\section{TOOK PRIZES AT THE FAIR.}

From W. A. Calhoun, East las Vegas, New Mexico.

I raised Hubbard squashes, Big Tom pumpkins, Ford Hook watermelons and several other kinds. I had about one-fourth acre of squashes and melons. I plowed the ground last fall,

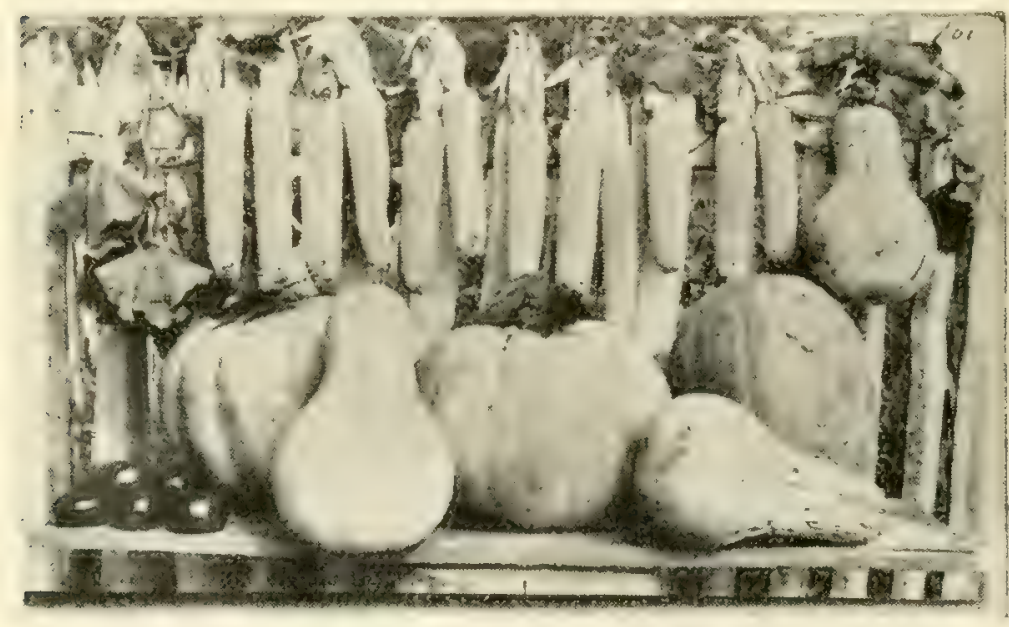

Missou:i Corn, Squashes and Tomatoes as deep as I could plow it, four rounds to the land, and then I filled the open furrows with stable manure. The tenth of May I dug out the manure where I wanted the hill and planted five or six seeds to the hill about ten feet apart, tended them with a culti ator, and they yielded prelly well. We had no rain in August and September, or I would have had a larger yield.

I had in about a half acre of beets. They done pretty well, some will weigh six lbs. I had fourteen rows of Fillbasket peas ten rods long. We had all we could use and gave a good many to the neighbors, and sold upwards of $\$ 20.00$ worth. I listed the ground last fall and planted the peas from the 25th of March to the middle of April in the lister furrows and cultivated them with a cultivator and hoe. Planted the beets about two feet apart and tended them with a cultivator and hoe.

We had a little fair at Las Vegas, and I took first on the following best display of vege- 
tables: Stock beets, hog millet, pumpkins, squashes, oyster plant, sugar beets, and took second on cantaloupes. I had to compete with mountain and irrigation to a great extent, so you can see that I had to have something to show.

W. F. Calhoun, East Las Vegas, New Mexico.

\section{PLENTY OF PROFIT IN GARDENING.}

From Quincy Mrers, EdDYYille, Iowa.

I put 150 tomalo plants out May 24th, and I sold from this 150 plants $\$ 128.00$ worth of tomatoes, some at $10 \mathrm{c}$ a $\mathrm{lb}$. some at $8 \mathrm{c}$ and so on. Part of them were Field's Early June, Earliana, and Sparks. I will recommend Field's Early June. Cabbage was poor. I sold from onehalf acre $\$ 54.74$, watermelon, Kleckley Sweet, one acre, $\$ 69.60$; muskmelons, \$190.03; sweet potatoes one acre, sold most of them at 3 c per lb., \$149.24; cucumbers, one-half acre, $\$ 41.19$; Irish potatoes, one-half acre, $\$ 29.30$. Plants of all kinds, \$115.20. A few green onions from four bushels of sets, $\$ 24.05$; radishes from about the

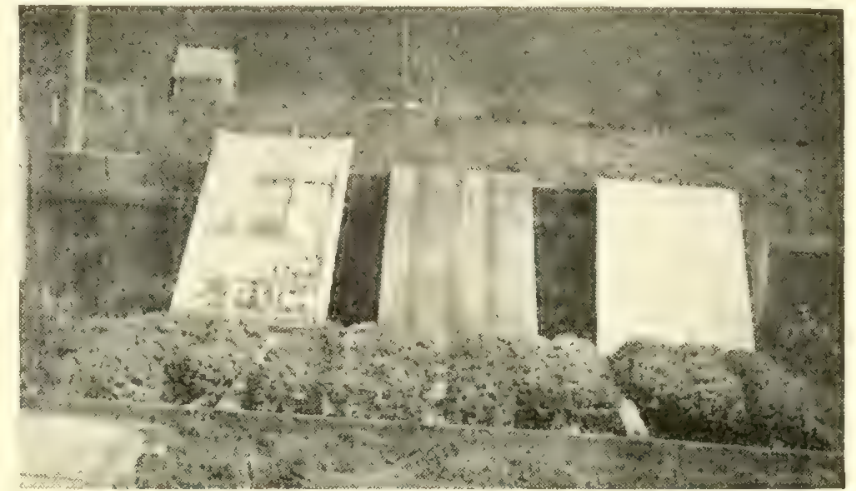

Lettuce, heads of which weighed $2 \frac{1}{2} \mathrm{lbs}$. each same amount of ground as onions, \$18.10. Rhubarb, lettuce, turnips, egg plant, beans and so on amounted to $\$ 67.35$. I have about $71 / 2$ acres all told which I farm. This is as near correct as I can get it.

Quincy Myers, Eddyville, Iowa.

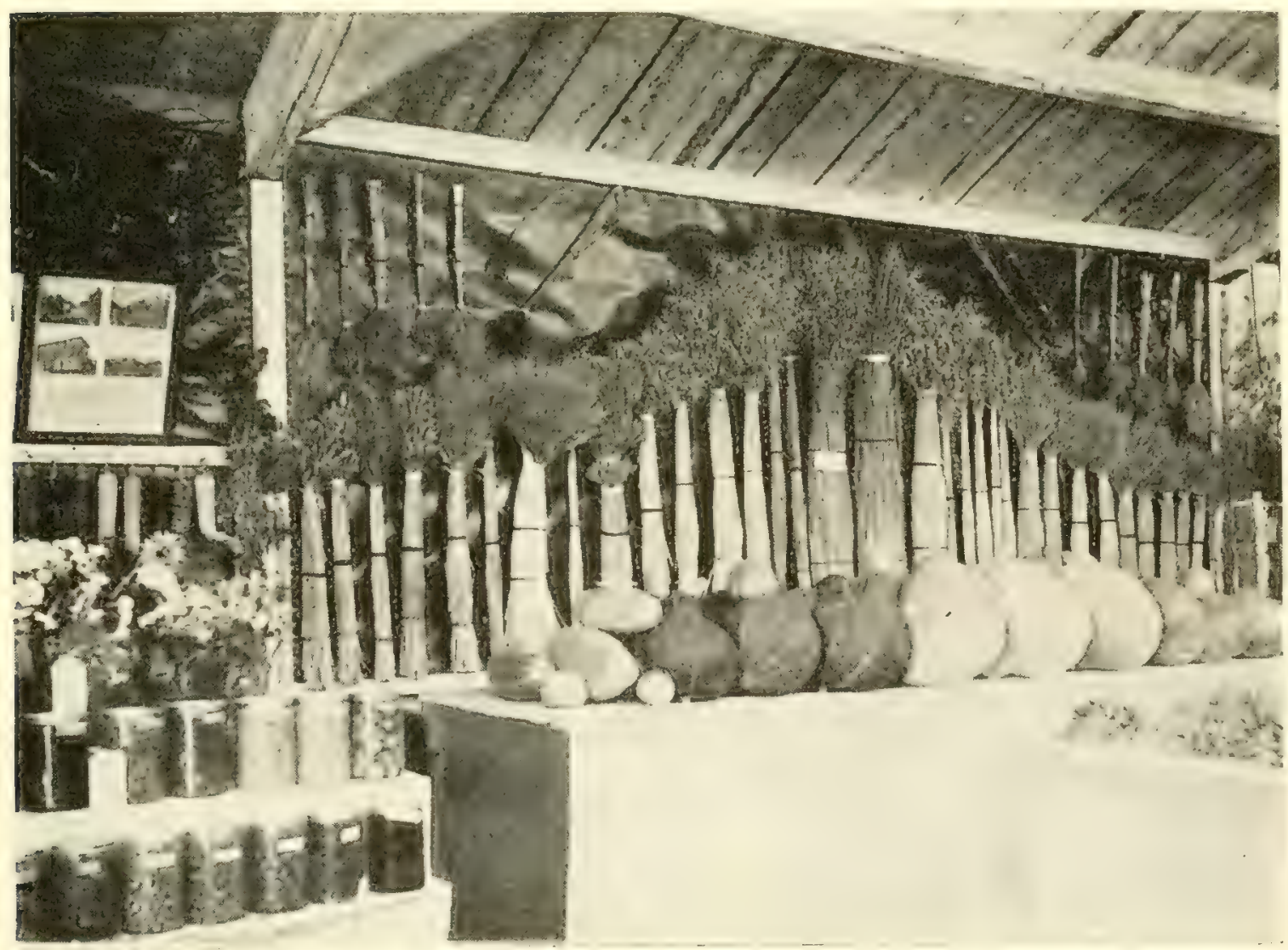

A prize exhibit 


\section{THE BOOK OF A THOUSAND GARDENS}

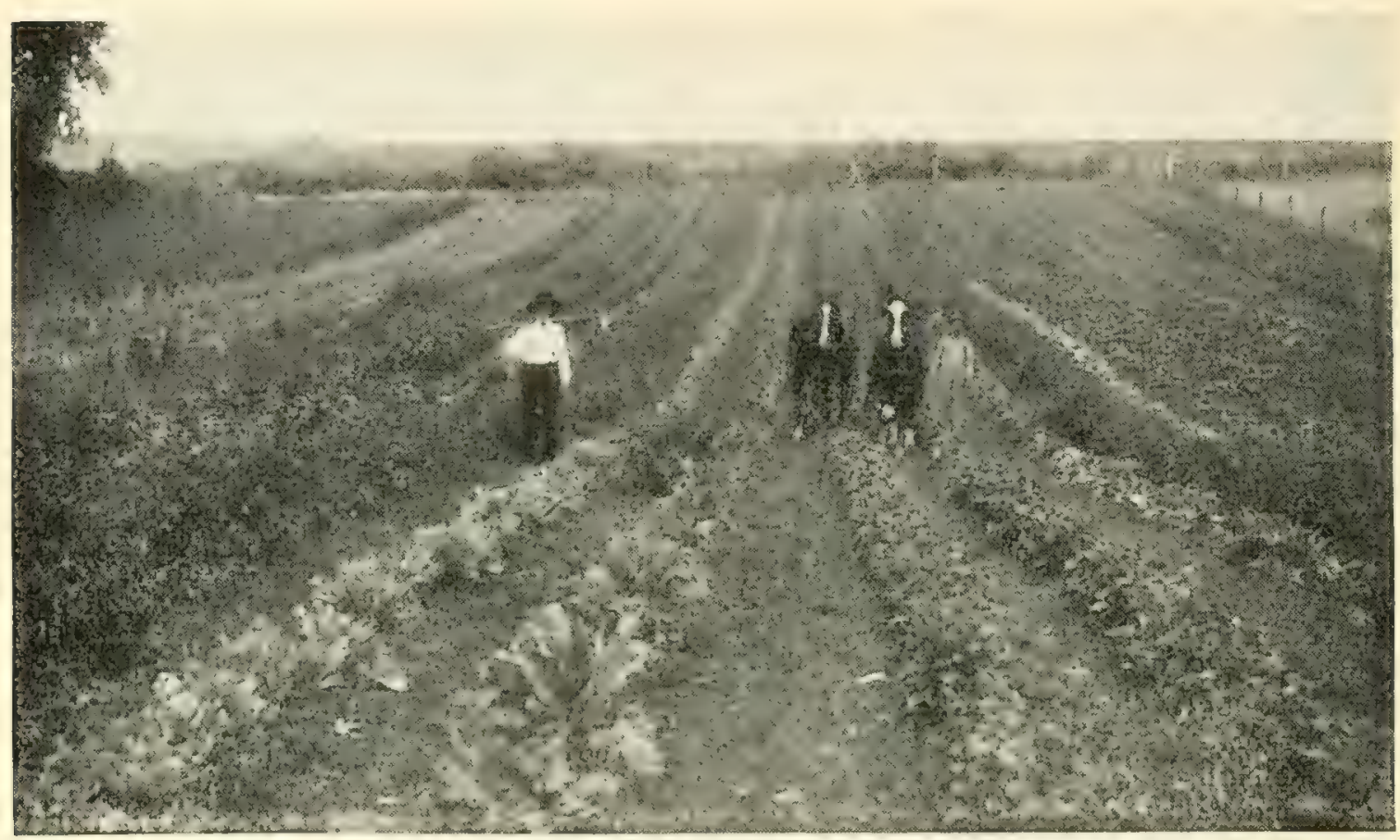

$\Delta$ fine Iowa garden. Everything in long straight rows, wide enough to le cultivated with a horse cultivator

\section{"A PRETTY FAIR STAGGER AT A GARDEN."}

From Mrs. James Patterson, Burnt Ranch, Calif.

I think I have had a pretty good sort of a garden-considering. If I am to be judged along with professionals and others who have hired help and finely cultivaled ground and all sorts of tools, I am sure that I stand no chance for your consideration, but if you judge me from a feminine viewpoint, (I am a voter now, you know), on what I really accomplished against heavy odds, I believe you will say with my old neighbor, "That it was a pretty fair stagger at a garden."

I am a city-bred woman and this is my first garden-thanks to you, Mr. Field. This is a homestead in the Trinity National Forest which we have just taken up. It is in the northern part of California where we have early frosts, much snow and a short summer, and we have only trails to travel on. I started my garden on a rocky hillside having a southern exposure. I brought water to the spot in a little ditch. We have no summer rains. I hired a decrepit Chinaman and a little boy to take off the top layer of rocks, and I did the rest. I worked with the pick, the shovel, the mattock and the hoe. I planted, sowed, cultivated, irrigated and harvested this garden by myself upon soil which had never before been upturned by the hand of man.

My garden spot was $32 \times 48 \mathrm{ft}$, with young peach trees set out at $16 \mathrm{ft}$. intervals and several large madrono stumps in between and numerous small ones. The only fertilizer I had at hand was wood ashes from my cook stove, and I got a few bushels of borrowed manure in my tiny seed bed, but I worked early and late with the little water at my dis-

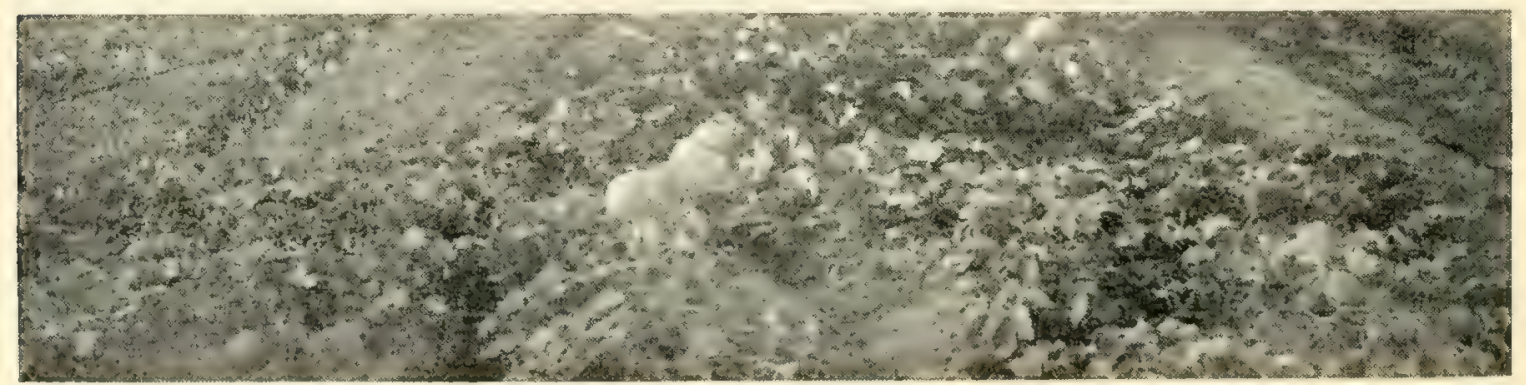

Rocky Ford Canteloupes 
posal, and took advice from every brain that came my way whether in print or on foot. I got some chicken wire and made a weak, feminine fence around my garden, and of course hogs broke in, it was such a temptation, and ate all my cabbage and string beans and other stuff just when it all was beginning to grow, but they grew up again and finally gave me my reward.

Of course I crowded things in my garden. I never knew a number four shoe was so big until I tried to walk in between my rows, but my experience tells me that it is rather good to crowd things on new unfertilized ground where you have little water. The plants shade the ground and prevent evaporation. Also rocks are not half bad. When laid around a plant they will keep moisture in the ground. Did you ever try it?

Now, Mr. Field, you will want to know about my vegetables. Kentucky Wonder Beans,

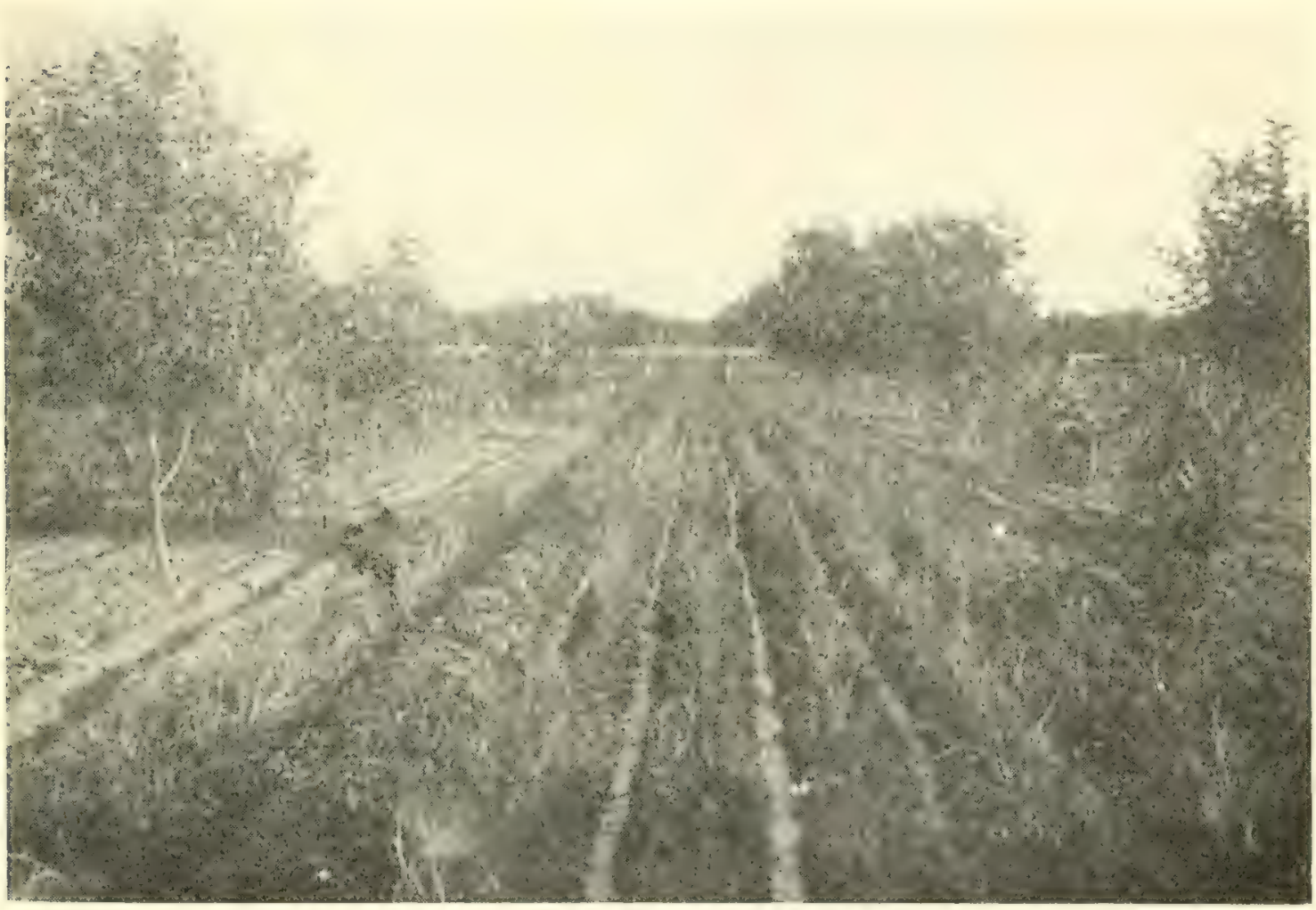

Irrigating Onions and Lettuce

grown on the fence, fine and prolific. Leltuce, fine, more than we could eat; onions grown from sets, small but satisfactory; cabbage, some early, plenty of the late varieiy. Beets, zarrots, turnips, poor, we don't care for them anyway. Italian Spinach, good; radishes, White Icicle, good. Watermelons, small but very sweet, over one hundred from a tiny palch. Summer squash, fine; sweet peppers, "measly." Hubbard Squash, my pride, the best in the neighborhood. Have put away 36 fine ones and have a lot of little ones for present use off a plot $14 \times 16 \mathrm{ft}$. My sweet corn was an after-thought, planted in a poor spot with numerous stumps to break the rows, but it afforded us a good many messes of small but sweet ears. But it prozed one thing to me, and that is there is nothing in this cry about having acclimated corn. I bought corn from four sources and planted it all practically the same day. Yours, Mr. Field, grown in Iowa, came up and ripened long before the California variety. Golden Bantam was the kind I used.

I considered my garden a success, because I accomplished what I started out to do, supplying my family with fresh vegetables for the entire summer and with some left over for the "rainy days."

I almost forgot to mention my flowers. I planted them in beds along with vegetables, that was my only ground available, and they were and are still lovely. Also, incidentally, along with this gardening I did all my housework, washing, ironing, etc.

Mrs. James Patterson, Burnt Ranch, Cal. 


\section{A GARDEN WORTH SEEING.}

From Frederick Fite, Parkton, Maryland.

The seed I got from you is all O. K. Every one came up in my garden. Potaloes were a failure here, but tomatoes yielded a fine crop. Everything in my garden, with the exception of sweet and Irish potatoes are first-class. I am very sorry I am not able to send you a photograph of my things I raised. I can recommend no seed as highly as yours for it is unsurpassed, also the flower seed is fine. I have a nice bunch of flowers in my garden, and everybody that sees them is surprised. I will get my seed from you next year, if I live, also a good many of my friends will get of you.

Frederick Fite, Parkton, Maryland.

\section{SHOULD PLANT MORE STRAWBERRIES.}

From Ora Carter, Lyndonville, Vermont.

My garden is $50 \times 100$ feet and my strawberry bed is $50 \times 50$ feet. I raised all we could eat for a family of nine, and I sold $\$ 3.50$ worth of vegetables. Raised 206 quarts of straw-

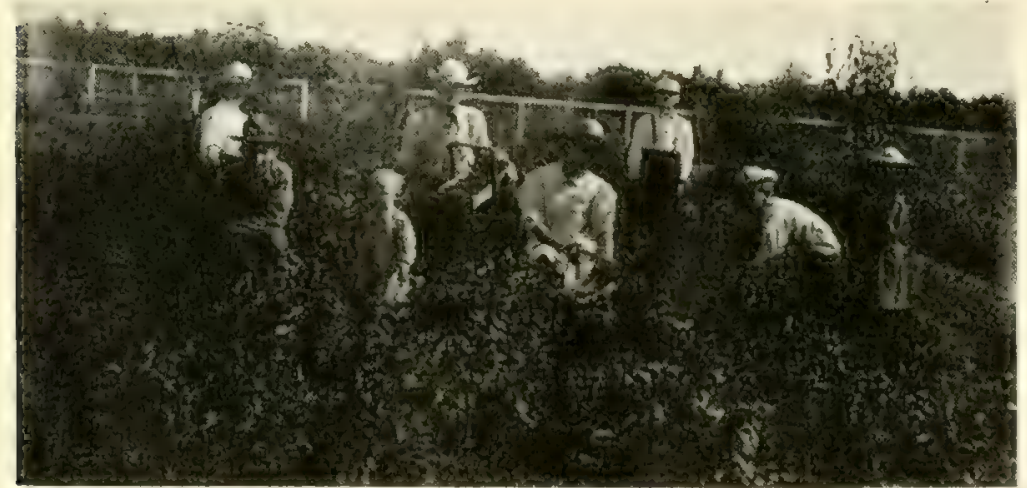

All hands and the boss picking straw Demes berries and sold $\$ 17.00$ worth. Our market here is not very good for selling vegetables, but I can sell all the strawberries I have. They pay me best. I think I could have done better had it not been for the drouth.

I got me a camera in the spring, but in some way I could not make it work so I have no photographs. I took first prize at the children's garden class fair for best vege-

table garden, and my brother also took a prize. I will send you the paper so you may see for yourself.

Miss Ora Carter, Lyndonville, Vermont.

\section{HERE'S HOW HATTIE GOT AHEAD OF THE BUGS.}

From Hattie Case, Bremer, Iowa.

My garden is 40 feet wide and 175 feet long, not counting a strip by the fence for a walk. It was all covered with a well rotted stable manure, and after the grain was in, the men plowec? it quite deep, then harrowed it until it was as mellow as an ash heap. Then they hitched to the harrow and standing on the double tree, in that way planted the whole garden. I did not plant it all in a day or a week even. As soon as anything came up I went through it with a hoe.

I set out early tomato plants between the rows of early peas. The other tomatoes, I planted the seed in hills, and as they grew pulled out all but one plant in a hill.

The striped bugs got after the melon and cucumber vines, and I got after the bugs. I took wood ashes and put in enough kerosene to make them damp, then put a little on each plant. I had no more trouble with the bugs. The blister beetles wanted to take everything in the garden. These I scalded in hot water, pinched off their heads, stepped on them, and killed them any way I could. For the cabbage worm, I put a teaspoon full of Lewis Lye in a pail of water. I sprinkled the plants with this several times in a season.

I had a fine garden, took a display down to our County Fair and got a prize on it. I cannot tell which paid the best, as we eat all we can of what we raised, some we give to friends, and a little we sell. I believe we are enjoying our salsify the most just now.

Everything not killed by the hail was very nice. We ate tomatoes by the peck, and I have fifty-one quarts canned. I sold nine nice large heads of cauliflower and quite a few squashes. We ate our last watermelon Oct. 23rd. A good garden is sure a fine thing. 


\section{A BUSHEL OF BEANS FROM 14 HILLS.}

From B. J. Schaerer, Ronan, Montana.

I want to tell you of the success I had with the seeds I purchased from you. The four pounds of Red River Early Ohios yielded $43 \mathrm{lbs}$. of large round potatoes, but had the ground been in proper shape would have received double the amount.

From fourteen hills of Missouri Wonder Pole beans planted in the same field without poles or trellises, I got over a bushel of large beans. The radishes grew to mammoth size. I pulled one that measured 15 inches long. The carrots yielded 90 lbs. out of four rows eight feet long. The melons did exceedingly well, but were planted too late. Some of my beets measured more than 15 inches in circumference, and turnips as large as a one gallon fish bowl. These were all grown on dry farming. I think the yield was remarkable. B. J. Schaerer, Ronan, Montana.

\section{THE BEST GARDEN IN NOOKSACK VALLEY.}

From Ed. M. Williams, Deming, Washington.

I have tried my best to get my garden photographed, but met with failure. However, I did not fail with my garden. I have at the present time one pumpkin that will no doubt weigh $50 \mathrm{lbs}$. My mangles will, I believe, average $4 \mathrm{lbs}$. each. Cucumbers and pumpkins had to be replanted owing to the three weeks' cold, drizzly rain rolting the seed in April. Everyone passing on the road admired the garden and the pretty flowers. Planting a garden close to a highway is a good incentive for doing one's best in the garden.

I believe we have the best garden in this part of the Nooksack Valley, and can, I believe, furnish ample proof of that fact. I had no help but did the work alone, and we had to drop work in the garden when the hay was ready for cutting.

My garden plot is $480 \times 270$ feet.

ED. M. Williams, Deming, Washington.

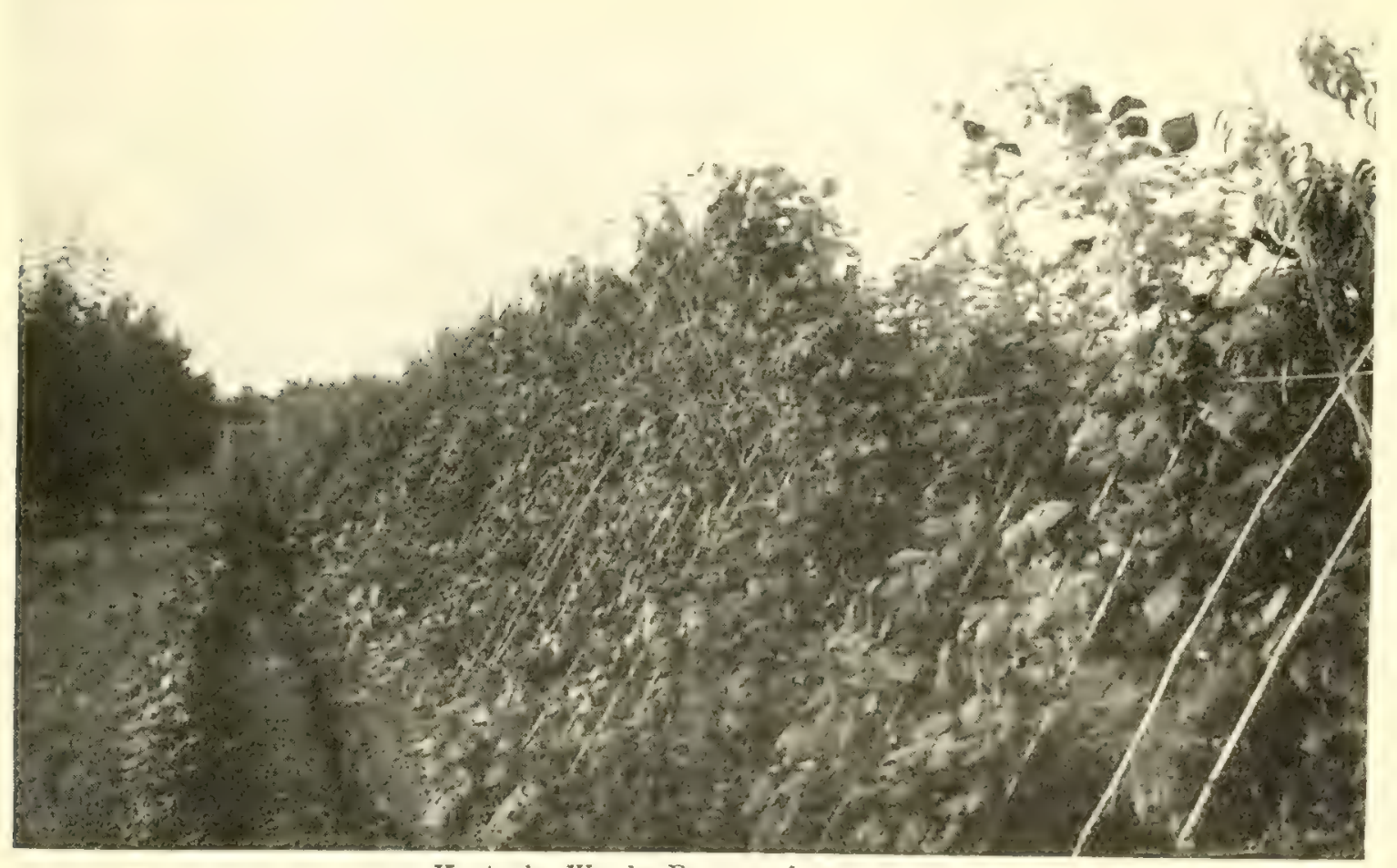

Kentucky Wonder Beans on bamboo poles

\section{A GOOD IDEA.}

From Mrs. Nora Moore, Mt. Moriah, Arkansas.

I cullivate as near level as possible in drouthy country, because the plants stand hot weather so much better than on beds. I have tried both ways.

Mrs. Nora Moore, Mt. Moriah, Arkansas. 


\section{PLENTY OF GARDEN STUFF AT CLEARWATER.}

From Mrs. J. W. Lupfer, Clearwater, Nebraska.

My garden met with bad luck all the way through. It was taken by the cut worms and

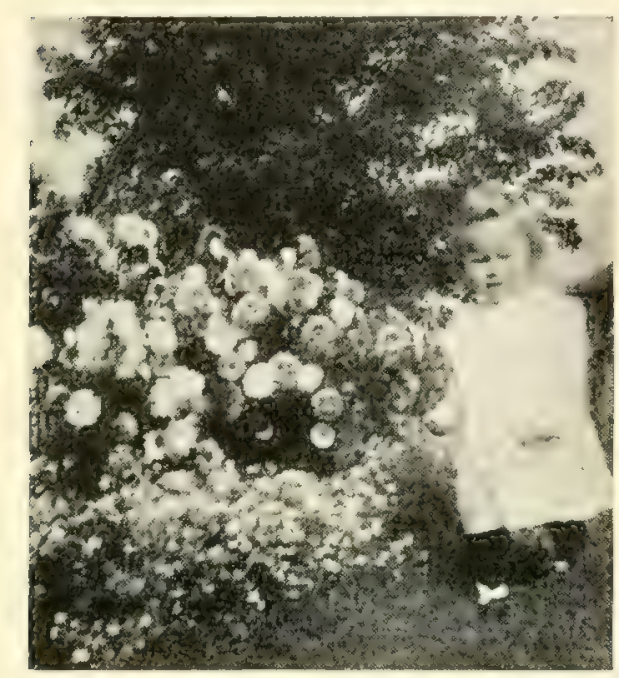

She is just looking at Mamma's flowers. Wouldn't think of picking themespecially if closely watched chinch bugs the first of the season, and then the drought, and then hail. So you see I didn't have much chance to win.

I had about three quarters of an acre. Had seventeen rows of potatoes, and have had them to eat since the middle of July, and have enough to last two weeks yet. Had about two loads of watermelons, but not very large ones. Will have about 50 or 60 small heads of cabbage. Plenty of tomatoes. Have gathered about two bushel of Cherry tomatoes. Had plenty of peas, and have nearly one-half bushel dry. Had about three bushel of onions after eating from them since the seventh of May, and will have plenty of set for another year. Had about 100 muskmelons. Also a few flowers.

I hoed my garden over four times, and hand weeded my onions and small garden once a week. I hope I will have better luck with gardening next year.

Mrs. J. W. Lupfer, Clearwater, Nebraska.

\section{A VERY SMALL GARDEN BUT A GOOD ONE.}

From Levi Parson, Griffin, Indiana.

I have had a fine garden for the season. The size of my garden is about $10 \times 11$. The best I raised this year was beets. They were fine size. The tomatoes and lettuce was fine also. Radishes were no good at all. I laid it to the season. The cucumbers were fine.

I got a question to ask you. Do you know of anything that will keep the worms off of cabbage?

Levi Parsons, Griffin, Indiana.

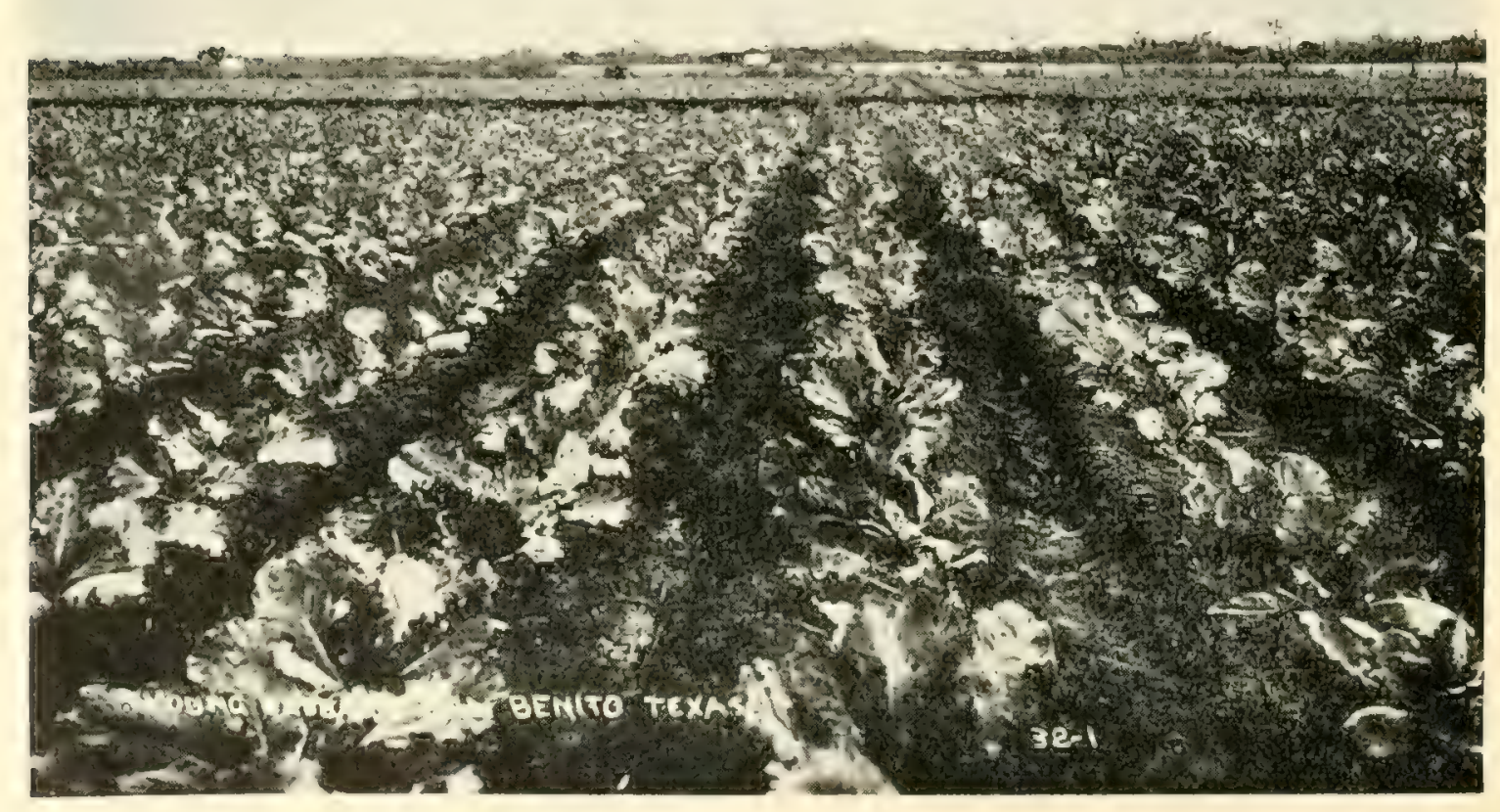




\section{THE TALK OF THE NEIGHBORHOOD.}

From Wm. C. Davis, Bridgeton, New Jersey, R. No. 3, Box 54.

My garden consists of one acre. My first planting is in February. I plant peas, if the ground is not frozen, and then in March I put in onions, beets, radishes, lettuce, and sow cabbage for early plants. I have had peas up eight inches high and covered with snow, but the cold and snow does not effect the early peas. Sow the Alaska for early and use Field's seeds. After these crops are gathered, the same ground is prepared and set in Colden Self Blanching celery, making two crops per year from the same ground. On the balance of that strip I

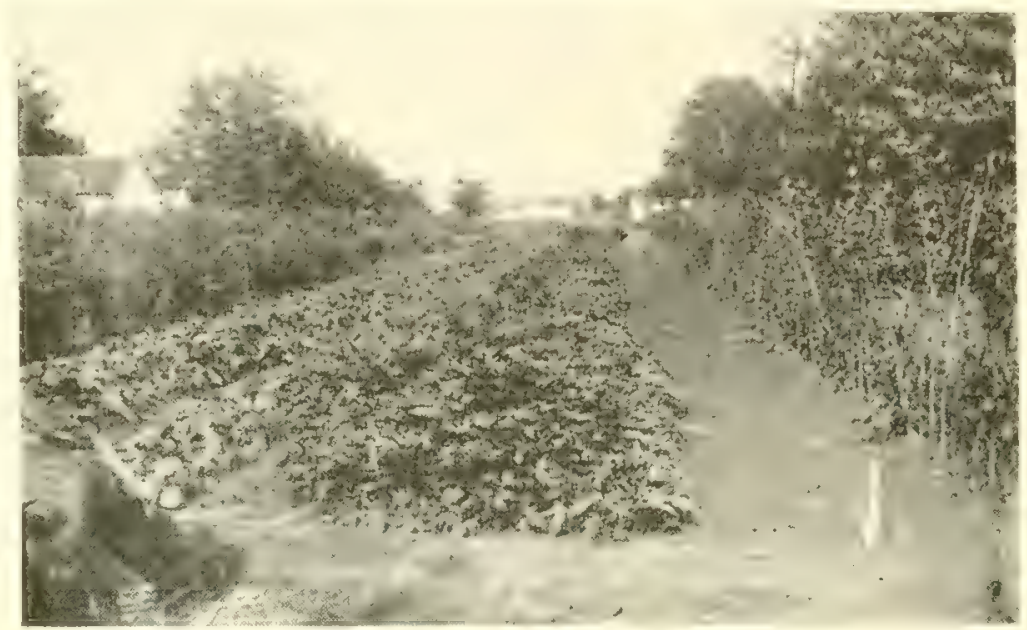

A garden that pasd ror being well tended

plant Lima beans, bush and pole, set tomatoes, peppers, plant sugar corn, string beans, squash, cucumbers and cantaloupes.

My garden is the talk and admiration of the neighborhood. My most profitable crops are strawberries, cabbage and cantaloupes. I use manure broadcast and high grade fertilizer in the row. I raise two crops of each with the exception of strawberries.

Those Field's Daisy cantaloupes. I have been gardening 45 years, and they are away ahead of all others.

Wm. C. Davis, Bridgeton, Nen Jersey.

\section{\$125.00 FROM A HALF ACRE. GOOD.}

From Mrs. W. J. Daugherty, Henry, Nebraskí

The first thing to do is to plow deep and harrow thoroughly in the fall, if possible, and scatter well rotted manure over it. By doing this, the ground is in shape for early planting.

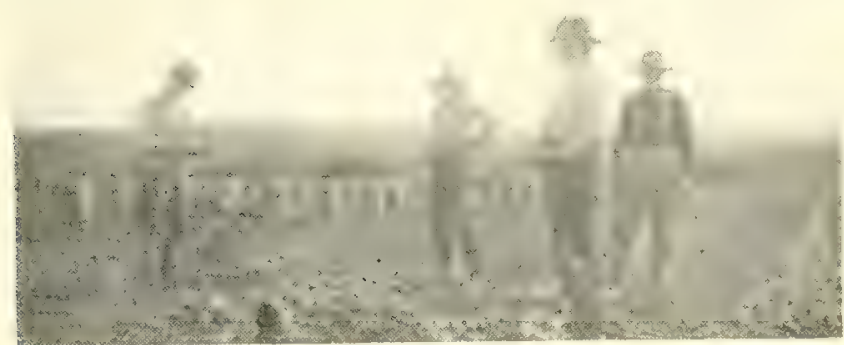

$13 / 2$ acre Onion field which yieided $₫ 58$ sacks - about $125 \mathrm{lbs}$. each

My garden of one-half acre was planted to the following: One-eighth acre in onions, the balance in cabbage, tomatoes, peas, beans, beets, lettuce, turnips and carrots. I raised at least 50 bushel of onions worth $\$ 1.00$ per bu.; about 3000 lbs. of cabbage, which sells here from a cent and a half to three cents a pound, and 10 or 15 bushels of tomatoes worth $\$ 2.00$ per bu. here. This would amount to about $\$ 125.00$ from one-half acre of ground, not counting the other vegetables at all, and besides my garden was not planted till the 10th of May, which was very late for onions. Next year I shall try and plant them in March or April.

I use the Planet Jr. garden tools, which I find a great help. In fact, I would not do without them. The seeds were bought of Henry Field, and I find them fine in qualily and quantity. I tried Field's Early June tomatoes which are excellent and just as they are represented.

When my garden was in the nicest stage for taking photographs, there came a terrible hail storm, beating it up so badly, I did not get any pictures. Therefore my letler will have to be sent in void of any photographs.

Mrs. W. J. Daugherty, Henry, Nebraska. 


\section{SHE USES THE IRON AGE DRILL AND WHEEL HOE.}

From Mrs. Harvey Griffith, Milledgeville, Illinois.

A few years ago my garden was a bayn yard. It had been cultivaled for two years, so the soil was in ideal condition for a good garden crop. I do not grow vegetables for market, but want an abundance for home use and just sell the surplus.

My early cabbage, lettuce, radishes, onions and peas were grown in a corner of the yard. They only did fairly well. The dry weather injured them.

The piece of ground for my garden proper is a $a_{-}-t$ eighty-five feet long and thirly feet wide. I planted everything in long rows, and used a small garden plow, that boon to women

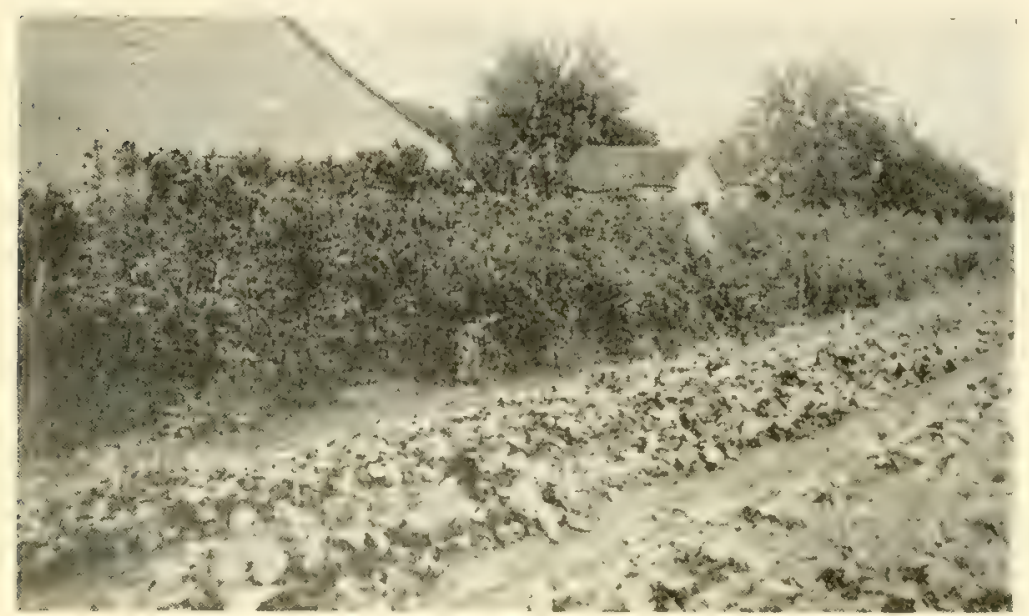

Results shown iu August gardeners for cultivating. I had one row of tomatoes, one row of bush beans, peppers and egg plant. One row of pole Limas, one row of pole beans, one row beets, four rows of late cabbage, a row of cucumbers and three rows of Colden Bantam sweet corn. Then I had a corner about seventy-five feet square planted to watermelons, muskmelons, pumpkins and squashes, and one short row of parsnips made the whole of my garden.

And such a garden. Sweet corn ready for the table the last of June. Some of the early kind planted July tenth made fine roasting ears as late as October fourteenth. The tomatoes, peppers and egg plants yielded more than we could use and some were sold. I also sold about a bushel of cucumbers. Some of the peppers were four inches in diameter, and one egg plant was eighteen and one-half inches around.

The watermelons and muskmelons were fair and the squash and pumpkins extra good. I have almost a wagon load of the two together. The bush beans were rather poor, but the limas were good. I have about a peck of shelled limas, and also about a peck of the pole beans shelled, after using all we could before they got too old. The Kentucky Wonder, Missouri Wonder and Golden Cluster Wax beans were planted at one time. The Kentucky Wonder were the first to ripen with the Missouri Wonder a close second, and there is still an abundance of the Colden Cluster Wax.

My cabbage, the Volga, is the best I have ever raised. Such nice sized heads and so white, sweet and crisp. The cabbage, with the parsnips, squashes, beans and canned tomatoes and corn will mean vegetables on the family bill of fair until spring, and used with the polatoes that were raised out of the "Garden" will make the grocery bills small. Mrs. Harvey Griffith, Milledgeville, Illinois.

\section{HOW WAS THIS FOR A 6-FOOT SQUARE GARDEN.}

From Miss Mabel Smith, Northboro, Iowa.

My garden is 6 feet square each way. It is on low ground where it is very good soil. It has a kind of a low sandy ground. I made a ditch to drain the water off so it would not go on the garden.

I planted my garden May 8, 1911. I took my hands and pulled the weeds and kept it clean all the time. I gave some vegetables to others and used some at home. The sales were $\$ 1.05$. The tomatoes did better than any other things. They produced a gallon each day and were very large. The beans were very fine, too. I got them and put them in a buckel and brought them to the house and ate them. The beans were not very large because the ants bothered them. I put ashes on them and they quit, but did not grow after that. They were not large at all. 


\section{YOU CAN GROW ALMOST ANYTHING IN MISSOURI.}

From Charles Lang, Fredericksburg, Missouri.

I am going to write you about my garden. Last year in November I plowed my land, but I did not harrow it. In the spring I disked it and harrowed it and planted peanuts, but during the drouth they suffered a great deal. I hoed them often to keep the ground loose. I have dug some of them, but the rest are in the ground yet. There are many nuts on a vine. I will not sell them but will keep them for my own use.

I set out 420 tobacco plants, but it was a bad year for tobacco and I replanted them often. The worms were pretty bad, I picked them off three times a week. The tobacco is gathered and hung in the shed to dry. When it is dry, I will sell it at $15 \mathrm{c}$ to $20 \mathrm{c}$ a pound. I expect to make about $\$ 25.00$ out of it.

Charles Lang, Fredcricksburg, Missouri.

\section{MISSOURI TO THE FRONT AGAIN.}

\section{From}

Mrs. Jennie Brannam, Raymondville, Missouri.

I have the finest tomatoes, cabbage, corn, beans and parsnips and everything that is good to eat, and I have the only good garden in Texas County, Missouri. Have plenty of tomatoes for myself and neighbors and cabbage to sell. My neighbors all say they will order with me next season, for they see it don't pay to get old seeds.

I have plenty of proof that I have a fine garden and lovely flowers, too.

Mrs. Jennie Brannam,

Raymondville, Missouri.

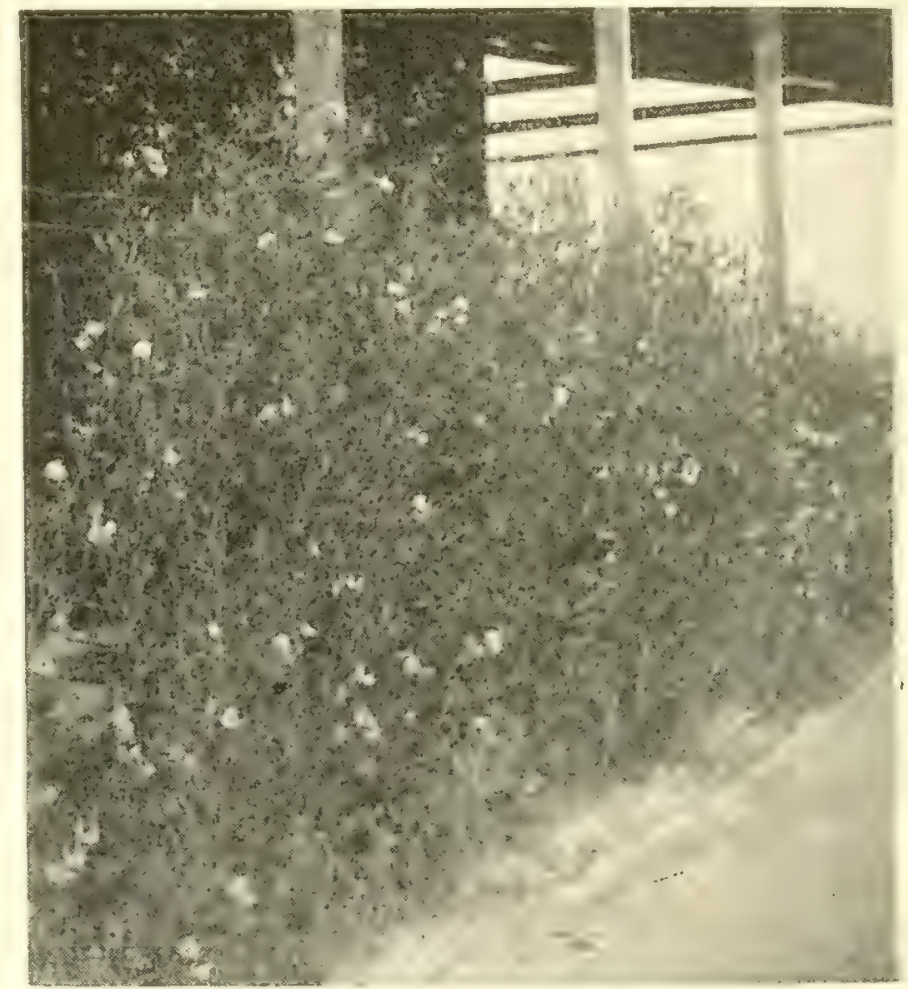

Spencer Sweet Peas $7 \mathrm{ft}$. tall in New Mexico

\section{VOLGA CABBAGE PAID BEST.}

\section{From Dewitt C. Ladue, Darien, Connecticutt.}

I only have a garden for my own use, nothing for market. The dimensions of my garden are about 100 feet long and fifty feet wide. I plant in long straight rows running north and south and cultivate with the Iron Age hand cultivalor.

We have had four straight summers including this one of severe drought. I am almost discouraged as to a garden any more. However, I cannot think of being whipped, so will try harder than ever the coming season with the hope of being favored with more rain.

My plan is to wait till the ground is right, then plow a narrow strip and plant the same day with good seed. I am not disappoinled in getting things up nicely, but the excessive dry weather has played havoc with gardens here this suason

The Banner potato is truly a great potato, withstanding drours. remarkably well. I plowed up the old strawberry bed after fruiting and set out Volga Cabbage plants. This is the only thing I can brag about this year. At first, I thought that they were all going to die, it was so dry. I kept them alive by welling them every evening until about the first of August when we began to get light rains. Well, the cabbage began to grow wonderfully until nearly every plant has made a fine head. I consider them the best solid heads I ever raised. 


\section{BEST GARDEN IN THE COUNTRY.}

\section{From J. E. Redenbaugh, Burrton, Kansas.}

I was squarely in the drought seclion, and I think as well as my neighbors do, that I have the best garden in this part of the country in spite of the dry weather. My garden was no: watered from the time the plants were set till it rained a few days ago, but constant cultivation kept it alive. We have now planted peas, beans, lettuce, radishes and turnip seed for late garden. We have had several messes of roasting ears, crowder peas, tomaloes, sweet potatoes, and cucumbers by the bushel, besides the early garden, such as peas, radishes, lettuce and onions from the seeds you sent.

We would like some good remedy to kill-worms on cabbage that you could recommend.

J. E. Redenbaugh, Burrlon, Kansas.

\section{A GOOD GARDEN IN SPITE OF DRY WEATHER.}

From C. W. Chiles; Climbing Hill, lowa.

I have a talf an acre in ga-den which I put in and tended as follows: I think it a good plan to have the ga:den plowed in fail and in the spring. Just before planting, cultivate

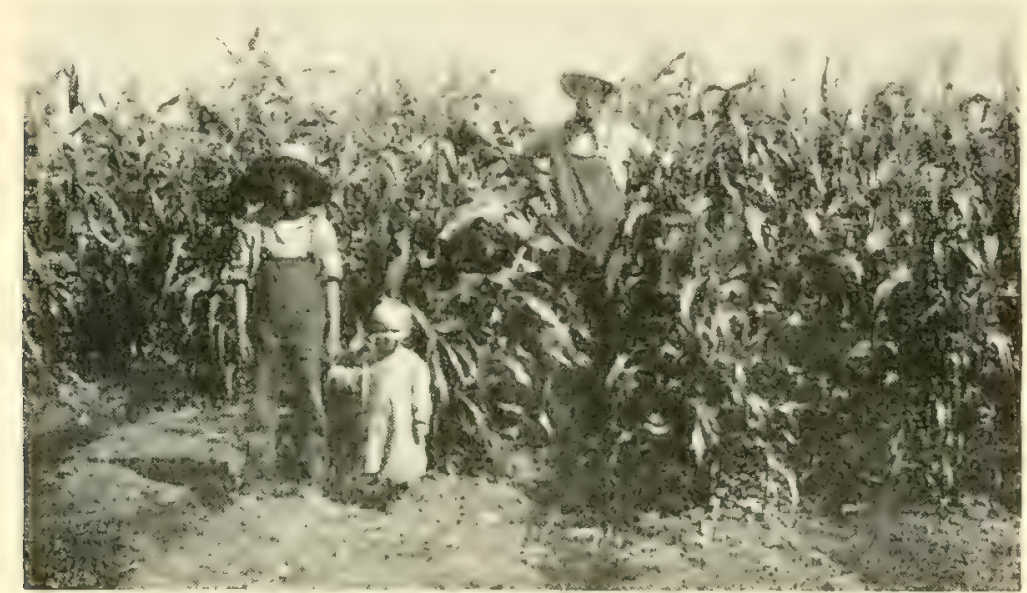

Sweet corn, $\$ 3: .00$ sold from a space $: 7 \times 250 \mathrm{ft}$, less than $1-6$ of an acre or disc good and harrow down smooth, but as I did not get my garden plowed last fall I plowed it in the spring, harrowed it down smooth.

I purchased one bushel of onion: sets, which, when set out, made Iwenty rows across the garden 18 inches apart. Next to onions I planted six rows early sweet corn. When I get one row of any kind of seed planted, I stick a stick at each end of the rows, and on these sticks I write the name of the seed planted, so I can tell just where the row is and what was planled in it. I planted all kinds of garden on across in the olher rows. We tended it mosily with a common garden hoe, and I think there is nothing that beats it for all around garden work.

As the dry weather struck us here, our garden is not at all what it would have been, had we had a good year, but it is fine any way.

C. W. Chiles, Climbing Hill, Iowa.

\section{WHERE THERE'S A WILL THERE'S A WAY.}

From Mrs, B. S. Duncan, Seaton, Illunois.

I believe where there is a will there is a way, and there are so many people who could if they would furnish their children better and healthier food than feeding them on canned goods.

Our place consists of four lots $60 \times 120$ feet. The house, lawn, barn, chicken yards fruit and garden occupy three-fourths of it. A twelve foot driveway runs through the, remainder. A four foot wire fence divides the garden into three portions, one combined with the fruit garden. In this one we planted our early garden stuff, onions, peas, beans, beets, spinach, lettuce, radishes, cucumbers and early potatoes. We just used it in the family. We had an abundance and it was fine. When we had used the garden stuff and picked the small fruit, we turned sixty White Orpington chicks in to forage.

In July we planted beans, radishes and lettuce and had delicious eating from them. We have a fine crop of lumips here, too. Along the driveway on one side, we planted sweet peas and climbing nasturtiums, and on the other side, Henry Field's Pole beans. They climbed the wire, furnishing shade, flowers and food. 
Now from something less than two lots, we have had an abundance of all vegetables for the summer, have four bushels of polatoes, eight of turnips, twenly of carrots, two of beets. Have canned Iwenty quarts of peas, beans and corn, forty of tomaloes, and 175 of fruit, and have three barrels of apples for winler use, and have several hundred dollars' worth of fine chickens.

Mrs. B. S. Duncan, Seaton, Illinois.

\section{IF YOU ARE TROUBLED WITH CABBAGE WORMS READ. THIS.}

From Mrs. Frank Downing, Gravity, Iowa.

I had a dandy good early garden, plenty of onions, lettuce enough to almost supply the neighborhood. I also had plenty of early peas and radishes. They were fine and lots of them. We planled about a half an acre of late garden north of the corn field. Well, we kept this free from weeds, and I believe it was the finest looking garden in the neighborhood, but when it turned off so dry and the hot winds begun to blow, we became discouraged and thought we wasn't going to raise anything. But being north of the corn field, we believe it was protected from the hot winds, for it slood the drought fine, and when the fall rains begun, how it did grow. It wasn't long until we could pick beans by the bushel. We raised more beans than we ever did before, and my late sugar corn was fine and lots of it. I also had lois of tomatoes

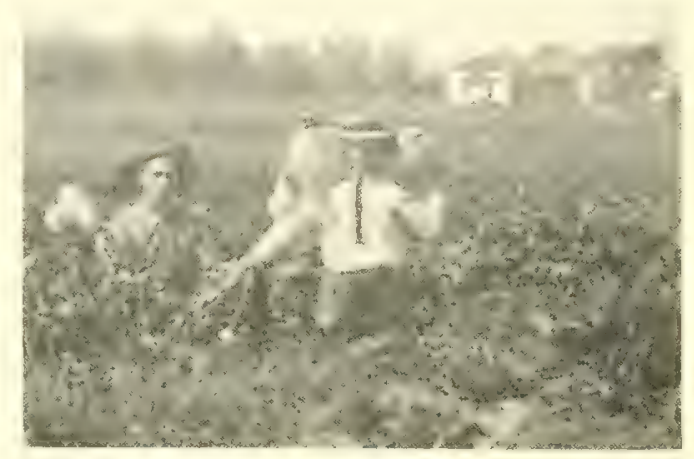

Some good cabbage and Japanese radishes and sold them for $\$ 1.50$ per bushel, and lots of cabbage which sold for $4 \frac{1}{2} \mathrm{c}$ per $\mathrm{lb}$.

I will tell you how I treat my cabbage to keep the worms off. First, I lake about a pint of salt to three gallons of water, then I spray my cabbage with this. Then in a few days while the dew is on in the morning, I go after it again, using flour and cayenne pepper. I use about a $5 \mathrm{c}$ box of pepper to a quart of flour. I believe this protected my cabbage from the worms.

I also raised plenty of cucumbers, muskmelons, watermelons, and in fact everything that goes to make a good garden. We never raised a belter garden.

Mrs.' Frank Downing, Gravity, Iowa, R. No. 3.

\section{PRETTY GOOD FOR A NINE YEAR OLD.}

From Martha Bruder, Atkinson, Nebraska.

I live on a farm ten miles northeast of Atkinson. I am nine years old, and am going to school now. My garden consists of about an acre of ground. After the seed was all planted, then began the fight to keep down the weeds and the insects away. About every eight or ten days papa went through between the rows with a one horse cultivator, and I followed up and pulled all the weeds out of the rows, also picking off all bugs and worms.

We have lots more truck than we can use, and as there is no sale for such truck this year, there is lots going to waste. The cabbage an onions will sell fairly well. I sold four heads of cabbage and got 15 cents apiece for them. I have left in the garden two hundred and fifty good big heads.' Some will weigh ten pounds. If I get 15 cents apiece for them, will get $\$ 38.10$ for my cabbage crop. Papa said he thought the onions would yield about 100 bushels. If I get $\$ 1.50$ per bushel they will bring me $\$ 150.00$. Will not iry to sell any of the rest of the crop. Papa said we will use what we can and give the rest away to the neighbors.

I had no expenses, as my papa furnished the seed and land for what vegetables we used. I guess he just did that to get me to work better. My onions were too thick to make very big onions. We always planted them pretty thick because they never would come up very good. This year, we got our seed from Mr. Fields, and I guess every bit of it came up. That is why we got our onions so thick.

My peanuts are fine. We will get atout enough to eat all winter. I pulled up two hills and got enough peanuts to fll a half gallon buck. They can be raised as easy as any crop. It is great fun for 'us kids to dig our peanuts. Papa said everybody ought to have their kids a little patch of ground to plant to peanuts.

Miss Martha Bruder, Athinson, Nebraska. 
VERY SORRY THAT FRED FORGOT TO GIVE US HIS ADDRESS.

From Fred J. Bates.

My garden consists of about 30 square rods planted in rows about 42 inches apart, so they could be cultivaled by horse power. You may think this a small amount for a farm,

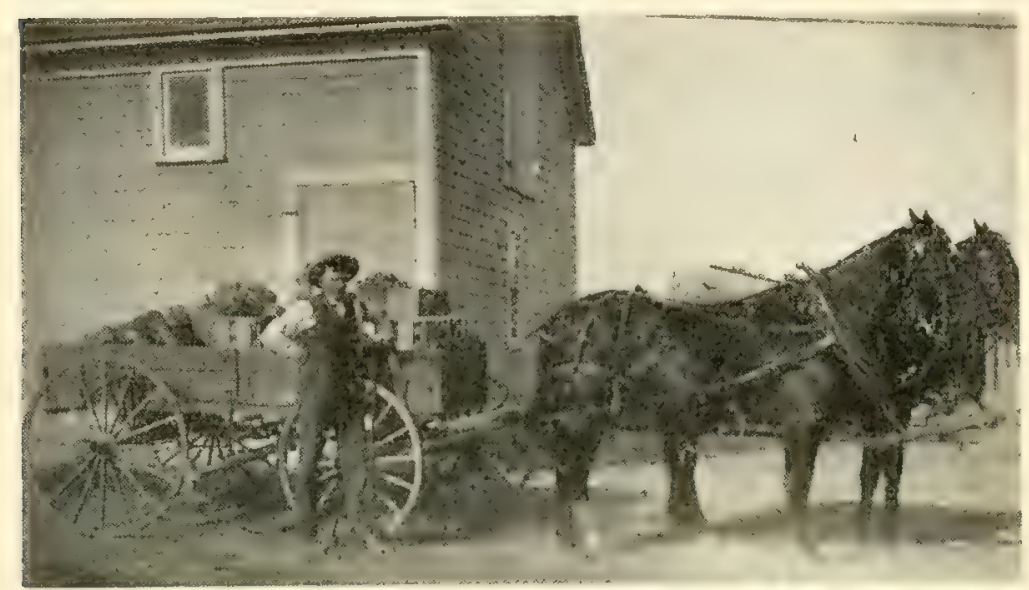

A load of truck ready for the market Sept. 4 th, 191l. Sold for $\$ 19.45$ but it supplied our table with all we wanted in the season.

I always plant my peas thick, use plenty of seed, as they come up quicker and stronger than when planted thin and it saves lols of work in weeding. Being wide in the rows they will stand planting thicker.

Lim a B e a s-It would have done you good to have seen those beans. We have a family of six and had four carpenters and other help, but they supplied

us with beans for more than three weeks unlil frost cut them down.

We had the largest, sweetest melons we ever raised. We had three kinds, medium to very large. We fed the carpenters iwice a day for three weeks, gave them to our neighbors, then lots of them spoiled on the ground. The box carpenter thought we had about an acre. When he saw them, he wanted to know where the rest of them were.

Tomatoes-Field's Early June did the best, and we had all we could use and gave away bushels to our neighbors. Just before frost, I piled them up, brought some of them in the house and we had tomatoes until after Thanksgiving. Early Cabbage-About fifty head. They did well, large fine heads and plenty for our own use.

Taking it all together with dry weather and bugs, we did well. I can see where 1 could improve on everything I planted by replanting as fast as the early things were up. My boys say that our garden was worth more than one hundred dollars, and I think they are about right, besides having things when we wanted them.

Fred J. Bates.

\section{HOPES TO DO BETTER NEXT YEAR.}

From Mrs. W. M. Hawkins, Glen Rose, Texas.

We just planted a small garden for home use, but raised more than we could eat. Would have done beller, but this has been a dry year in Texas.

Here is a list of what we sold:

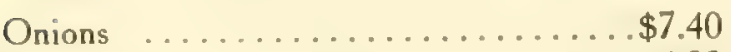

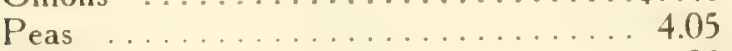

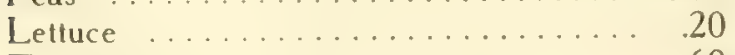

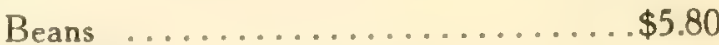

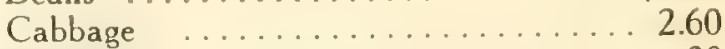

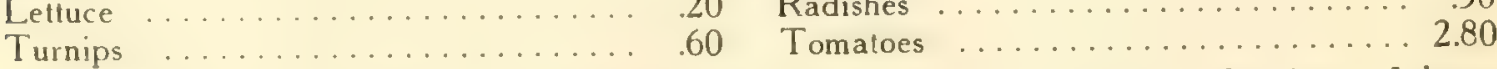

Sold in all $\$ 23.75$ worth, besides what a family of nine could eat all the time. 1 hope to do better next year.

Mrs. W. M. Hawkins, Glen Rose, Texas.

\section{MUCH DEPENDS ON THE WEATHER.}

From Mrs. Fannie Bush, Nelson, Nebraska.

My garden is entirely burned up. I had an abundance of radishes until the dry weather set in and they got so hot and strong we had to pull them up and throw them away.

Mrs. Fannie Bush, Nelson, Nebraska. 


\section{A TON OF BEANS FROM SEVEN-EIGHTHS OF AN ACRE.}

From B. S. Martin, Brownsville, Oregon.

Last spring I plowed up seven-eighths of an acre of rush sod, and on June 10th planted the same to White Mexican sweet corn and Improved Missouri Wonder pole beans, both bought of you. We sold one ton of green beans at an average of three cents per pound, besides supplying our own table for three months. We canned five thousand ears of corn, sold one hundred dozen ears at 10 cents per dozen, besides having all we could use during the season.

I have given considerable attention to pole bean raising for several years, and have grown your Missouri Wonder for seven or eight years and can truthfully say the same stands at the head of all of the varieties I have ever grown. Besides growing the above corn and beans, we grew on the same land some Big Tom Pumpkins, which are the pride of my four little boys.

\section{B. S. Martin, Brownsville, Oregon.}

\section{A GARDEN WHICH PAID.}

From lola Gott, Blountville, Tennessee.

There is about one-third of an acre in my garden. I had one-half of it plowed last fall, and the remainder was plowed in the spring. The garden was harrowed with a drag harrow, and was then laid off in rows three feet apart, except where I had my onion bed. I laid it off with a hoe, rows only 18 inches apart. There were 18 rows 30 feet long. The bed yielded nine bushels. I sold $\$ 2.00$ worth and $61 / 2$ bushels left.

I planted ten rows of Burpee's Stringless Bunch beans. The rows were about 65 feet long. They yielded very abundantly and paid me better than any vegetable I ever raised. Sold twenty bushels besides the number of bushels we ate. The first I sold at $\$ 2.40$ per bu. and the last at 50c per bu. Then I planted corn between the rows July

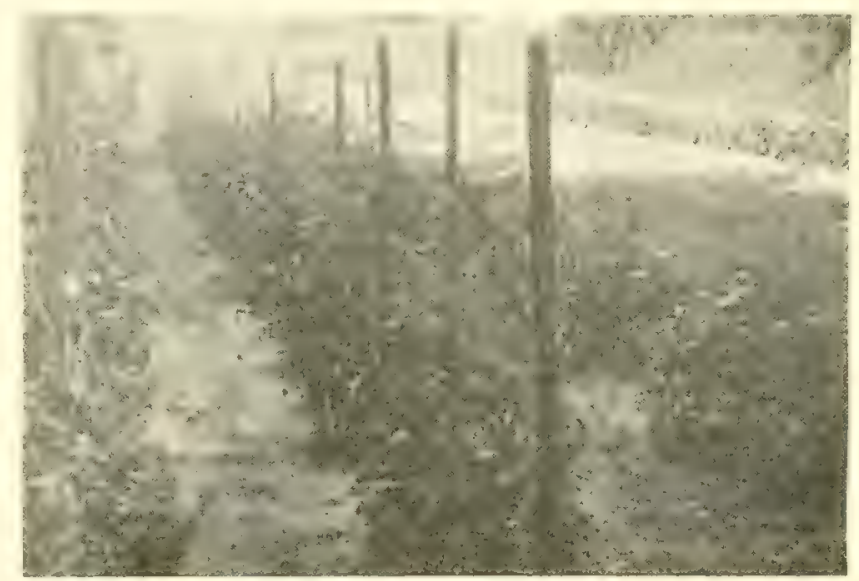

A well kept garden $10 \mathrm{th}$ and raised a fine lot of late corn and some good fodder, too. I only planted 100 hills of the Golden Rod Pole beans, and about the same Creaseback Pole beans. These bore more than we could eat and will want for seed.

I had eight rows 35 feet long of tomatoes. They bore abundantly. Besides the many bushels which rolled, I sold ten bushels and used 30 bushels.

Lola GotT, Blouniville, Tennessec.

\section{HAD POTATOES WEIGHING A HALF POUND AT MT. PLEASANT.}

From Elizabeth Junick, Mt. Pleasant, Pennsylvania.

My garden is about an acre. I sow my tomato seed in a bed, and I put in a little salt to keep the insects away. When about four inches tall I plant them out, hoe them for a while, and have a very good crop, some weighing as high as one pound. I treat the ground for cabbage about the same as I do tomatoes. I had some weighing 15 to $20 \mathrm{lbs}$. I plant potatoes in rows two feet apart, hoe about them about three times, and had some weighing about a half pound. 


\section{SUCCESS WITH WATERMELONS IN MAINE.}

From Mrs. Mary S. Allen, Litchfield, Maine.

As the watermelons have got ripe and been gathered, I have got a little something to say now about the Princess watermelons.

They beat everything I ever saw in the line of melons. They are something fine. I raised from 20 seeds, 27 melons in all. I did not

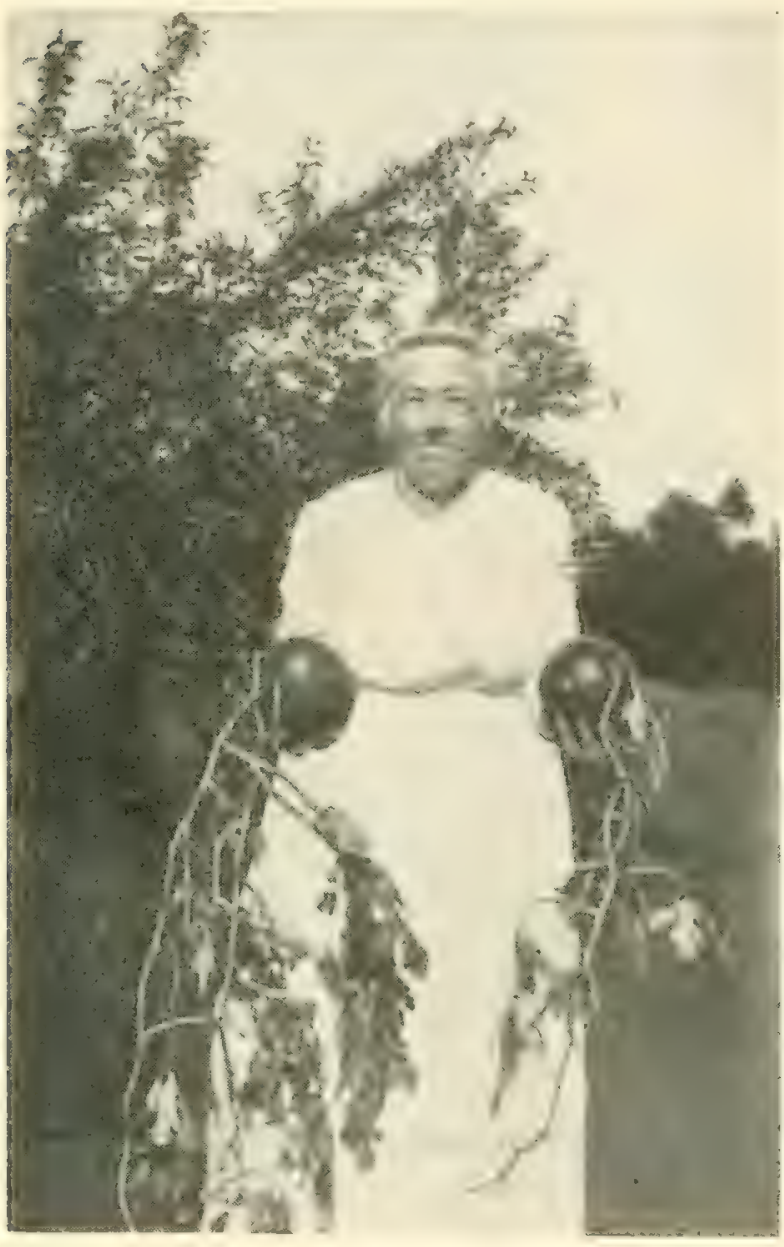

Mrs. Mary S. Allen, and her "Princess"' Watermelons have as good a chance as I would have liked, but made it answer. There are trees around the garden so it was shaded some, but my melons were fine and there has been more than a hundred people to see them.

Bosion people camped on our shore and my garden has been a great sight for them. I had a picture taken of my melons when I was working in them. I had some as big as 20 inches around each way, and several were $171 / 2$ and 18 inches around, and so sweet and nice. The biggest one weighed 5 pounds.

I have learned how to plant them here in Maine. I made little paper boxes about as big as a tumbler, and filled with dirt. I made the boxes of thick paper pinned together with toothpicks. I planted the seeds in them in April and kept them in the house in boxes and set them out doors the first week in June.

They were a surprise to the people here. They are sweeter than any other melon I ever ate and the grain is so fine.

Well, I don't know as I can say any more to make it any stronger or to explain how pleased I am with my melons. If I am able to plant and care for a garden another year $I$. shall raise some more of them, but I don't know how that will be for I am 69 years the 5 th of last July, so it is uncertain with me, but the younger ones

I am sending you one of the pictures. I think they are fine. You will see that the melons were so large that it was all I could do to hold them in my hands." The one in my right hand is a bit the biggest.

Maybe some have done better than I have, but there is none that has tried harder than II have, and it ain't very easy to raise garden here on the Maine shore.

\section{Mary S. Allen, Litchfield, Maine.}

\section{$\$ 20.00$ WORTH ON A 50x60 GARDEN.}

From P. E. Dodds, Minco, Oklahoma.

I bought a plot of ground; fenced it with woven wire $60 \times 50$. I then planted a late garden. I watered it every week, hoed it twice and hilled it up well for dry weather. I then bought a hose after I had got it all hilled up well, turned loose water enough to wet the ground good, and it slayed damp a long time. I raised $\$ 20.00$ worth of vegetables besides all I kept for the family use, as I have four little ones to keep and maintain. I have showed over 100 people my garden. I cannol get pictures of my garden, as there is no photographer.

P. E. Dodds, Minco, Oklahoma. 


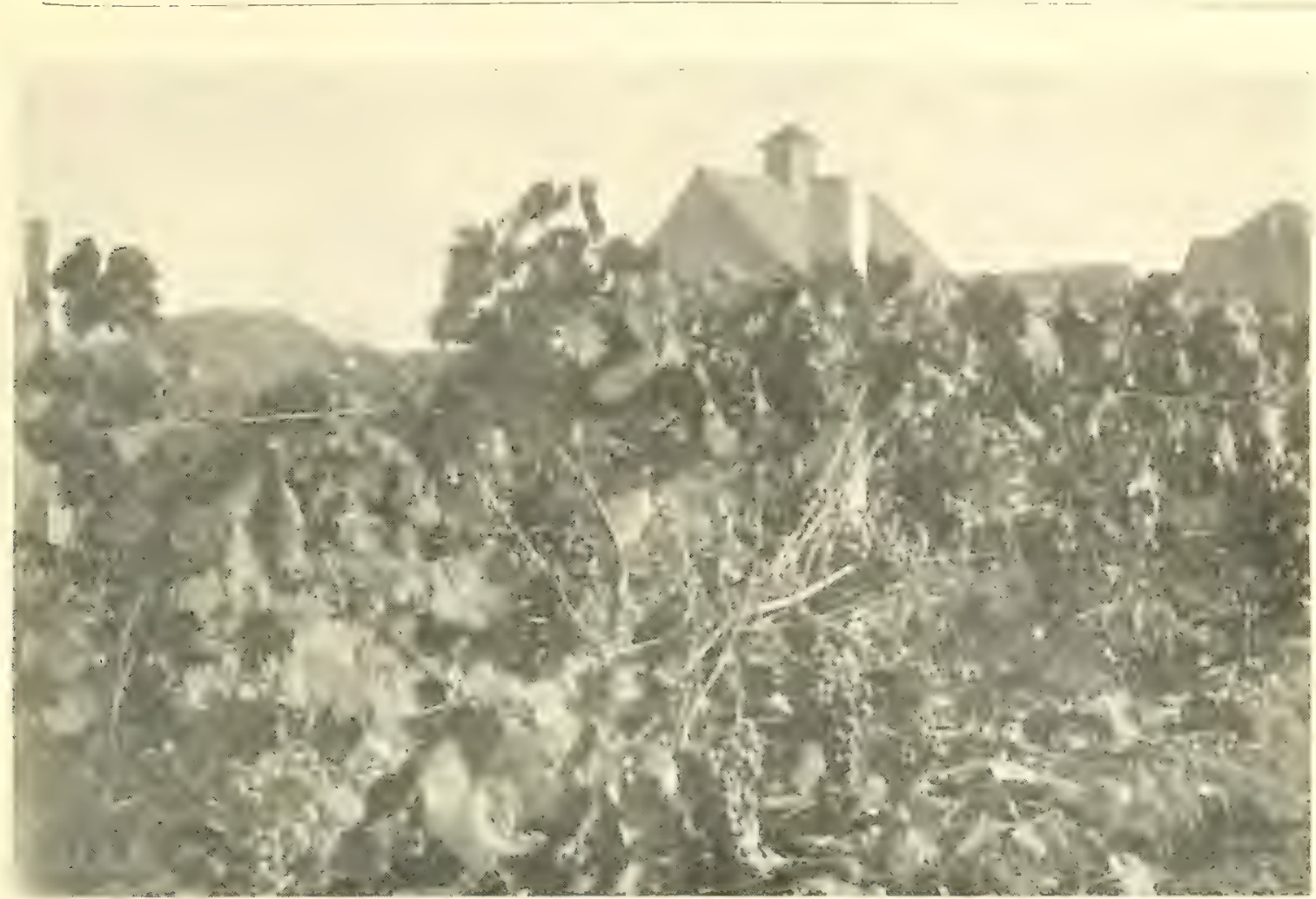

The grape patch

From Chas. Bruns, Garnett, Kansas.

Mr. Henry Field, Shenandoah, Iowa.

Dear Sir:-After reading your cheerful, encouraging, friendly letlers and catalog we feel as if you were our "real and truly friend" as the children say. For years we have been buying our seeds from others. We got good seeds and good results, but we never experienced a feeling of friendship towards them as we do towards you-l wonder why. We certainly do get splendid results from your seeds. Mr. Field, I wish you could have seen my garden last spring, summer and fall. I had a bountiful supply of "garden sass" from Easter till killing frost lime. We experienced a hard and very trying drought, but I had a fine garden. The only one in this neighborhood at that. My neighbors hung over my garden fence and shook their heads and wondered how I did it. I sold cabbage, cucumbers (slicers), tomatoes in July, early part at $10 \mathrm{c}$ a $\mathrm{lb}$, and no garden stuff in town but what was shipped in. Those Early June tomatoes are simply immense.

The Lima did fine too, but the hot, high winds were too much for them. Well, I cannot take time to mention each vegetable separately, but take my word for it it was simply a marvel how they stood that terrible drought.

Thanks for your personal interest, your truthful catalog, your help in all ways. Your well wishing patrons,

Chas. and Mrs. Bruns.

From John Travers, Londenberg, Pennsylvania.

Dear Mr. Field:-I am sending you a small order at this time just to get my hot-bed started.

You wrote me a very helpful letter last year. I have profiled by your advice. That's what helps a fellow when failure makes him discouraged. Thanks.

I planted Mixed Mammoth pumpkins and so forth the 28th of June last year. I thought I was too late, but Gee Whiz, you should have seen them, lots and lols of them of all kinds and all sizes.

With best wishes,

JOHN TRAVERS. 


\section{From H. O. Clayton, Spencer, Nebraska.}

Mr. Henry Field, Shenandoah, Iowa.

Dear Sir:- You sent me a new catalog and you want a letter so here goes. You say you had a good year and I am glad of it. It has been entirely different with me. All of the seed ordered from you were first-class in every way. We had a fine garden, the first one in three years and had that in the most unfavorable year of the three. I think it was the good seed.

The bushel of corn I ordered was O. K. I had a fine stand and it grew about three feet taller than my other corn, but the first of July we had drouth and hot wind so that no corn made much and of a poor quality. I think that the corn under ordinary conditions would malure here.

Now I want to know what you think about it, or if you would suggest some other variety? The corn I had was Shenandoah Special. I don't for a minute lay my failure to your corn for owing to the season, I don't see how we raised anything.

H. O. Clayton.

From A. C. Harford, Chicago, Illinois.

Henry Field Seed Co., Shenandoah, Iowa.

My Dear Field:-Two years ago I bought a quantity of grass and alfalfa seed of you. My neighbor bought his of a local dealer. Our fields adjoined each other; the ground was prepared in identically the same manner; the alfalfa was sowed the same day and put in the ground the same way. Both pieces were a good stand and one could see no difference in them. Both fields were cut the same day, July 6th. My field was cut twice after that, both cuttings yielding fine crops of hay. His died before it was large enough to cut the second time.

There has been a great deal of speculation as to the cause of his failure. I have always thought that the trouble must have been in the seed, and while I paid $\$ 5.00$ more per 100 lbs. than he did, I have always been satisfied with my bargain. Have you ever heard of alfalfa seed turning out this way before?

Thanking you for past favors and assuring you of my future business, I am,

Very truly yours,

A. C. HARFord.

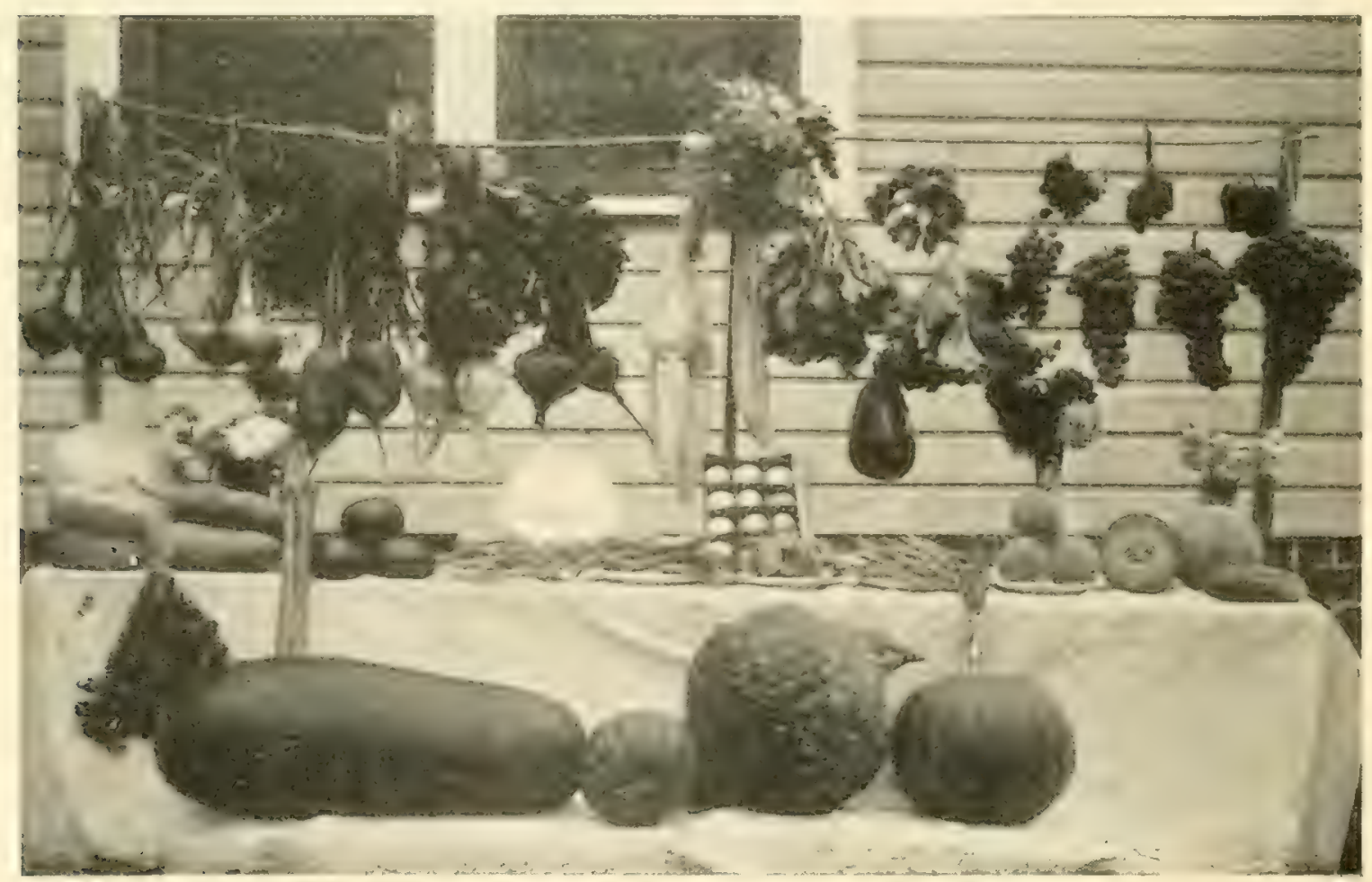

35 different varieties of vegetables gathered Sept. 16 th 


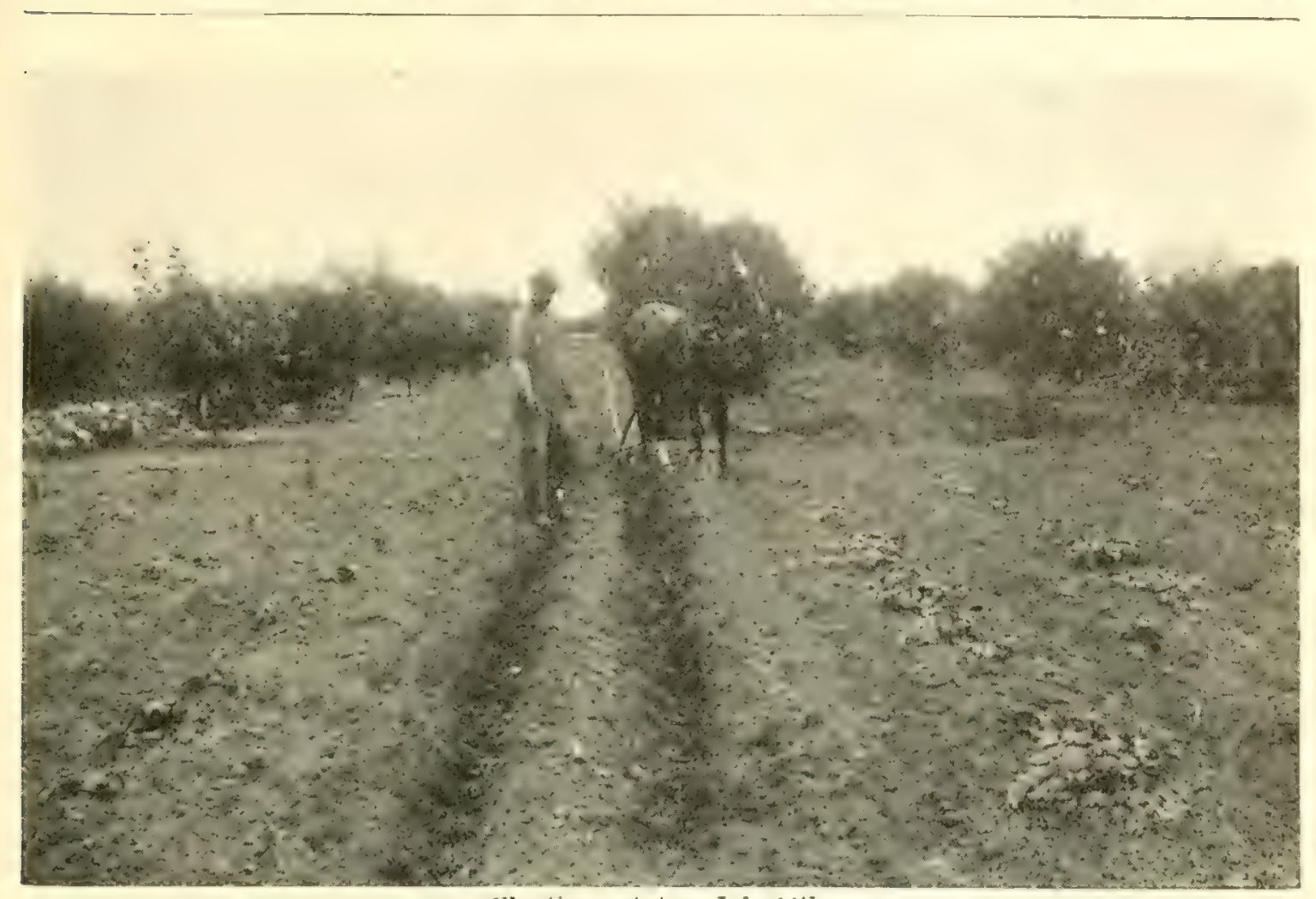

Planting potatoes July 14th

From W. L. Dale, Bassett, Nebraska.

Mr. Henry Field, Shenandoah, lowa.

Dear Sir:-The seed corn of Order No. received and tested. It is all O. K. Only one grain in tester that did not start. Am well pleased. Will order my garden seed later

Very truly,

W. L. Dale.

From Anna Pivoda, Grafton, Illinots.

Mr. Field.

Dear Sir:-I sent to you last year for a collection of garden seed. I cannot recall just what they all were, but anyway I made a success of my garden; especially with the Early June tomato and the Princess watermelon. I picked my first tomato on the 25th day of June, and my first watermelon on the 5th day of July; when at the same time my neighbors had no gardens at all, claiming the dry season caused it. I said to them that it didn't rain more on my garden than it did on theirs, but told them I had Field's Garden Seed which gave me fair crops in spite of the drought.

I am again sending you a small order trusting I'll have as much success in 1912 as 1911 proved.

Yours respectfully,

Anna Pivoda.

From Clovis Jauron, Salix, Iowa.

Henry Field Seed Co., Shenandoah, Iowa.

Dear Sirs:-About three years ago I sent for some of your Cornplanter corn and after trying it one season became convinced that it was a mighty fine corn but last year I had about twenty acres and it yielded fifty-three bushels, whereas my Silvermine only yielded me forty-two.

These two varieties were in ground that had been in corn for the last thirty years and what is called "Corned to death."

This year I am going to put in about forty acres. I have sold to date 48 bushels of the Cornplanter and made $\$ 96.00$ out of same. I claim it is the only corn for poor run down farms and that is the kind I am renting, but it won't long be that way. I am building it up every year.

(Signed) Clovis Jauron. 


\section{WHAT AN AMATEUR ACCOMPLISHED WITH A SMALL GARDEN.} From James Kibbee, 907 Broadway, Portland, Oregon.

Last fall we moved to a new location in the city, from a suburban home, and the city lot seemed very small and cramped to us. I had a strong case of "back to the soil" fever running in my veins, however, and I concluded I just must have a garden; and despite the difficulties

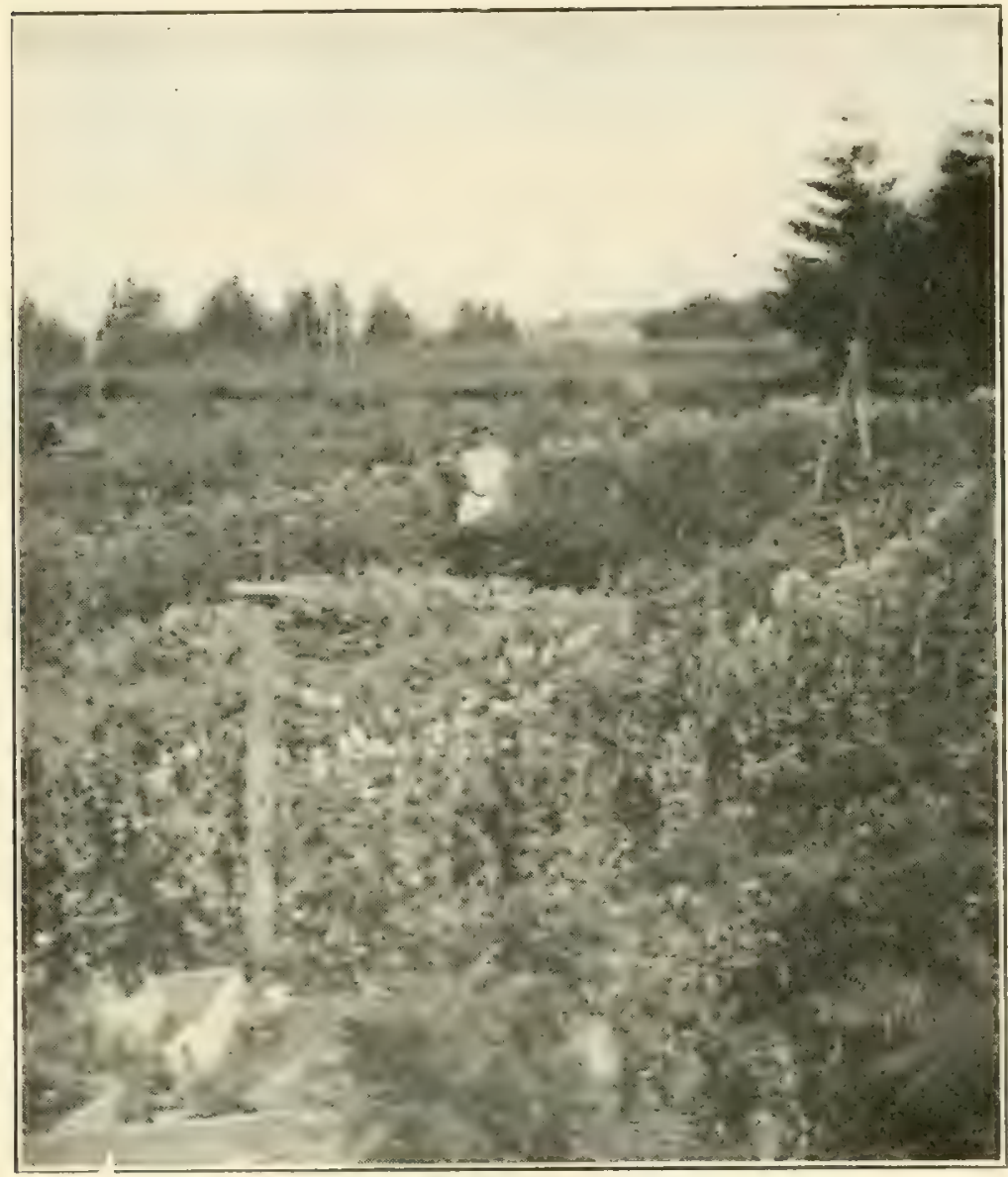

View of garden looking north. My little grand-daughter in the garcen which loomed up, I "goi busy." As fast as I goi a little patch subdued I made a little bed or row and planted it out. Bu: first I dug a six-inch trench all around inside of the four-foot chicken wire fence, and planted in the bottom of the trench: a choice lot of mixed sweet peas, making about a hundred and fifty feet of them. These were planted about the middle of March.

Of course, the first plantings in my garden were of radishes, lettuce, English peas, onion sets and spinach. Then quickly followed the beets, carrots, salsify, cabbage and cauliflower and celery plants and turnips; more radishes; more onion sels; then corn, beans, lomato plants, parsley, cucumbers, okra and more cabbage and cauliflower plants. Also a led outside the fence of flowers, such as aslers, poppies, pansies, hollyhocks, petunias, cosmos, elc. My corn, cucumbers, pole beans, and some other items were planted in small patches on either side and at one end (oulside) of the chicken yard fence.

During July and August we had but little moisture from above. Then I had access to the city water hose, and used it as oflen as needed between cultivalions. Of course, without this help from the city water my garden would not have been as productive as it has been, as we have had an unusually dry summer. As fast as my beds were emptied of their crops I replanted them, thus getting from two to four crops off of much of my ground.

Now, I have kept a strict record of the production of my little garden, and I am greally astonished at the actual results. But still I am sure that I could by careful attention and by profiting by the experience gained this year, accomplish at least 50 per cent better results next year. Just think of it! A plot of ground about $30 \times 60$ or 1,800 square feet, has produced under my amateur efforts, at the rate of over $\$ 800.00$ per acre. It proves to me that if the owners and renters of homes in the cities and towns of this great country would only utilize their back yards and the vacant places all around them, which the owners would gladly give them the use of, this question of the high cost of living would come much nearer being solved than it is.

I ordered thirty plants of Field's Senator for a starter and they sent me fifty; forty-five of these lived and made fine plants in spite of their long journey by mail. I am allowing only enough runners to grow to make a hundred and fifty plants in all, and next spring we will have all the strawberries my large family can use, and then plenty to can besides. When- 


\section{THE BOOK OF A THOUSAND GARDENS}

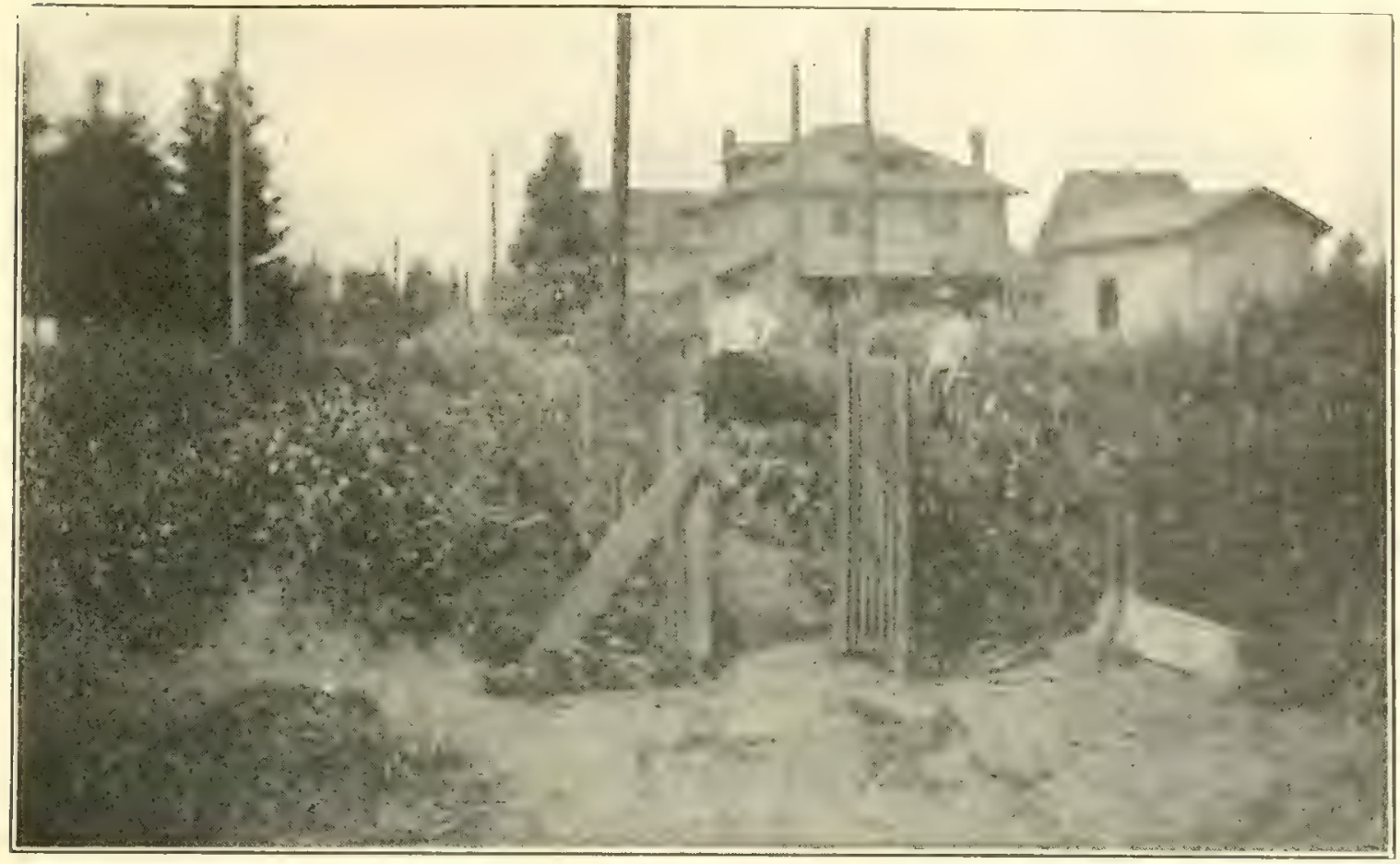

This solves the problem of - high cost of living

ever we have lots of strawberries, "we eat all we can, and what we can't we can;" see! For strawberries are our favorile fruit, and I never ate any canned strawberries like my wife can can. Her's have almost the exact fresh flavor and color.

To return to my garden, I must say that it has been a great factor in cutting down our living expenses. On July 16th, for dinner we had delicious fresh peas, carrots, young onions, radishes, cucumbers, and cabbage cold slaw, or salad - could have had more items, but surely that was enough for one meal.

\section{A FEW THINGS EXPERIENCE HAS TAUGHT ME.}

Success in gardening depends a great deal upon having good tools and in using them. One of the best tools I have ever used in the garden is the common, long handled, six-tined potato fork (with round tines). For spading up old ground, for fining the soil, making it mellow. and for knocking the clods and turfs all to little bits of pieces.

Cultivate your garden twice or three times where you water it once, and cullivate it again as quickly as you can after irrigating or after a rain.

Prune your tomato plants and train them to slakes or between three stakes, set

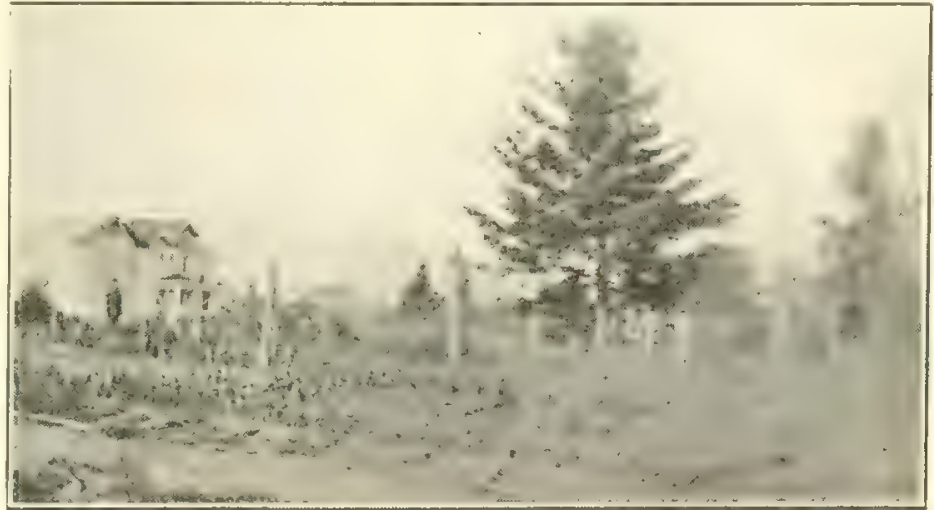

This view was taken when the farden was very young and is a poor picture thus. around the planis, tying strong strings around the outside of stakes to hold the plants inside the triangle.

The early peas did the best for me, both for earliness nad heavy yield. I like the salsify (or oyster plant) but I can't get my folks educated up to it. They say it's too violent a stretch of the imagination to call it "oyster plant"- too much of a "fake," but I have never yet come across a vegetable, properly prepared that I didn't like. 
The many bouquets of flowers in our house this summer have added a charm to the home never before experienced, and they well repaid the little trouble and care given them. Sweet peas and asters keep fresh for several days if the water is changed each morning. Nasturtiums with plenty of the green leaves mixed with them are fine, but don't last so well.

In planting sweet peas make a trench six or eight inches deep, and plant your seed in the boltom, at least one inch deep. As the plants grow, keep filling in the trench until it is level and then some. Keep them cultivated well, and give them a good support to climb on. Four or even five foot chicken wire is fine.

Asters are one of the finest of flowers; the many new varieties are, to my notion, giving the chrysanthemums a close race for beauty. They are easy to grow, and a bouquet of them will beautify a room for several days-they keep so well.

And the pansies; you can get more continuous performance of beauty stunts from a bed of pansies in a year than from any other flower that grows- far more.

I think a great deal of your Crimson Giant radish. Your Early June tomato looks and tastes good to me. I had quite a patch of Earliana and Stones growing when your plants came, and the latter were delayed and arrived in bad condition. I put them out at least three weeks later than the otheys, and in spite of their condition, they "humped" themselves right along, and soon caught up with the Earliana, which is some on the "hump" itselfand formed and ripened their fruits as quickly and as plentifully as their more favored rivals.

I have found that Swiss Chard is a fine substitute for spinach. But it is another stretch of the imagination to claim, as some of the seedsmen do, that the stalks of the plant are a good substitute for asparagus.

I attribute my comparative freedom from insect pests to the fact that I have some good friends as regular inhabitants of my garden-a number of birds and several frogs and toads. 1 have been careful to never scare away these friends, and I have come to believe that they know me, and that we are indeed, mutual friends.

\section{James Kıbbee, 907 Broadway. Porlland, Oregon.}

From Henry Jenkins, Ever, Kentucky.

Yes, Henry, I acknowledge my error. I did not buy my garden seed of you last year and I am now paying the error penalty. I haven't got my big white cabbage heads this winter that I would have had if I had bought my seed of you, and that is not all. I fell short in the vegetable crop in general.

Now about that 1912 order. I aim to send it in in a few days or a week at most, and if I need two cents worth of seeds or $\$ 200.00$ worth you may look for the order.

Yours very truly,

HENRY JENKINS.

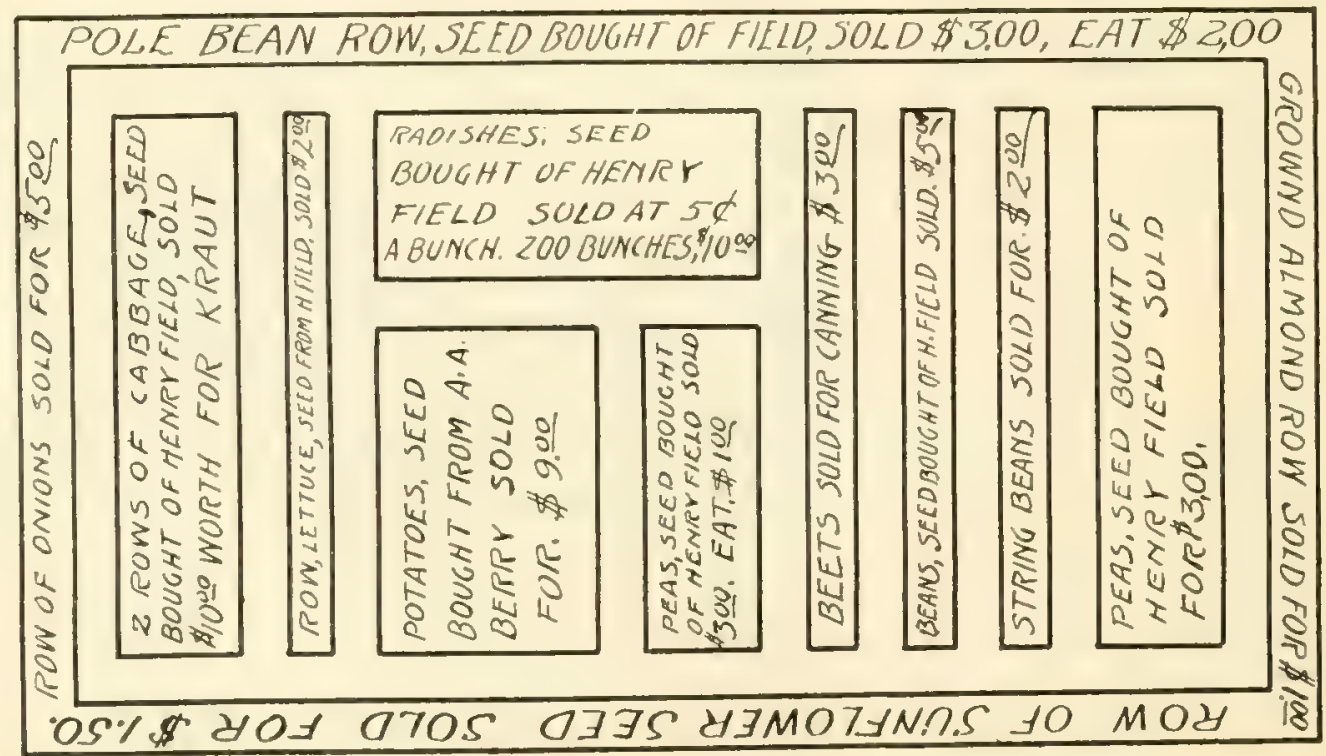

What one of my friends did with a small plot of garden 


\section{THE BOY WHO HAD THE BEST ACRE OF CORN IN IOWA.}

From Glen Mead, Percival, Iowa (14 years old).

This letter was not written by Glen himself. He was too busy being entertained at Washington by President Taft and the rest of the big bugs. His mother wrote me about it and I am telling what I can of it here.

It was this way. Last spring there was a state corn growing contest organized for the boys of lowa. The boy who had the best acre of corn in each Congressional district was to get a free trip to Washington, D. C. There were over 10,000 entries.

Glen sent to me for a bushel of Shenandoah Yellow corn, and took out of that seed to plant his acre. I didn't know him from Adam, and he didn't tell me that he wanted the corn for any special purpose, just sent in his $\$ 3.00$ for a bushel of corn and got the regular stock I was shipping to everyone.

The first I knew about his winning the contest was along in January when his mother was ordering garden sceds from me and wrote something about "Glen was so pleased over his corn, and was starting to Washington." She wrote that he planted the corn on some good rich river bottom land, on May 20th and it was harvested on Nov. 10th, by three disinterested farmers appointed by the contest board.

After making allowance for shrink from moisture, the corn weighed out $1021 / 2$ bushels of dry

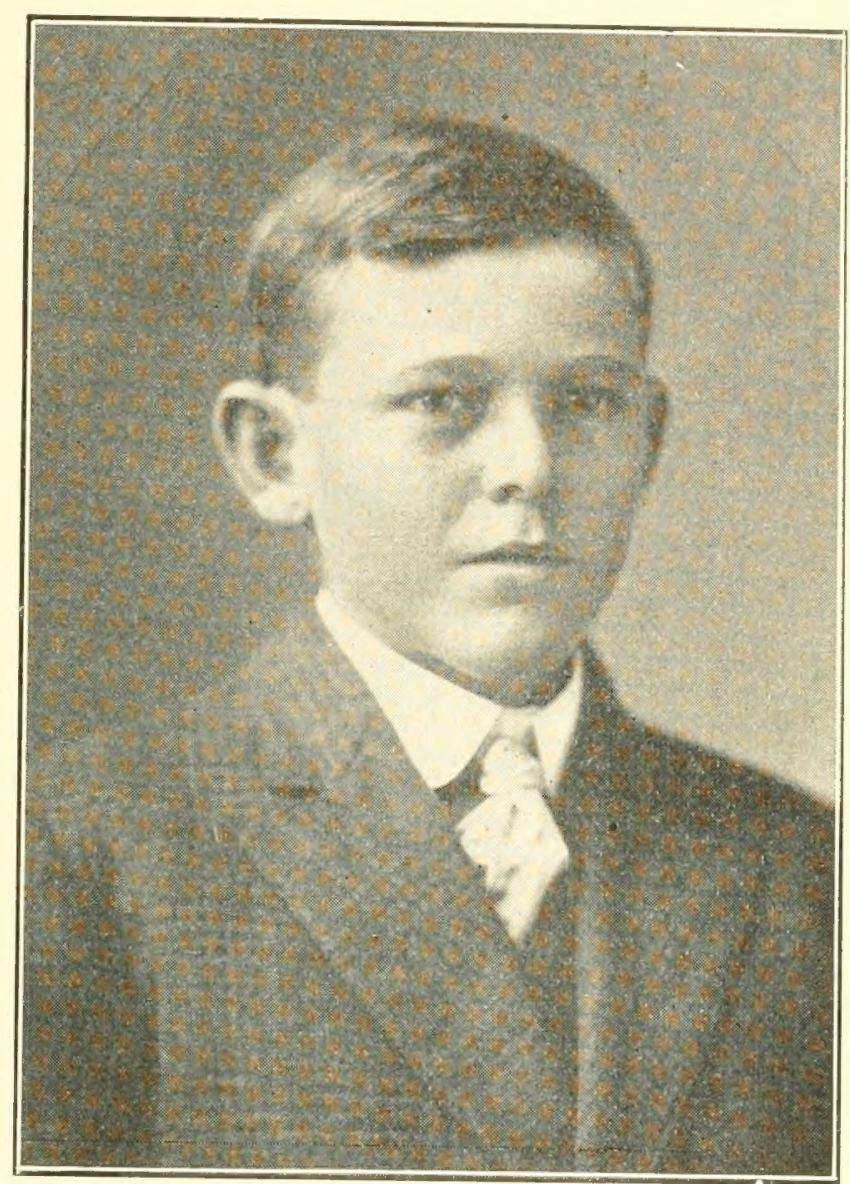

Glen Mead, Percival, Iowa. The boy who raised the best acre of corn in Iowa. Over 100 bu. of corn (Shenandoan Yellow) on one acre

shelled corn from an officially measured acre. No fertilizers whatever were used, and only regular good farming methods of planting and tending.

This was the best yield in this Congressional district and the best in the state. Good for Glen. It is a record to be proud of.-H. F.

\section{From W. L. Beckwith, Cottageville, West Virginia.}

Mr. Henry Field, Shenandoah, Iowa.

Dear Sir:- I have received several seed catalogs from different firms this winter but it seems somehow that I am partial to Henry Field. I have made the remark to my wife several times that I would not be afraid to risk Field for seeds for I believed him to be an honest man, and I only wish we could clasp hands as friends for it seems to me we are friends. I don't know why this is without it is because what little dealings we have had has been strictly on the square and I do admire a man that stands on his honor.

I will want some clover seed this spring, but it is so very high I hardly know what to say about it. Ought to have a half bushel. I have nine acres to sow. Thought I would write you for prices on Red and Mammoth clover for I believe your seeds to be pure, but I have had so much bad luck with clover and am hard up at present and I don't know that I will buy, but I wanted to write you anyway.

Wishing you a successful year, İ remain, yours respectfully, 
The one thing to be remembered in all this is that these people all used seeds from the HENRY FIELD SEED CO.

Although they come from practically every state in the Union the seeds made good every time. From Maine to Montana, from Florida to California, in the Ozark mountains, the Oklahoma prairies, the pine timber land of Wisconsin and the sandhills of Nebraska.

The results were the same everywhere-"The best garden in the neighborhood." Did you notice it?

You can have the same kind of a garden. I will furnish the seeds to do it with.

My catalog will tell you all about it. It is free for the asking and it's mighty interesting reading whether you intend to buy seed or not.

Send for it. Address:

\section{HENRY FIELD SEED COMPANY SHENANDOAH, - IOWA}





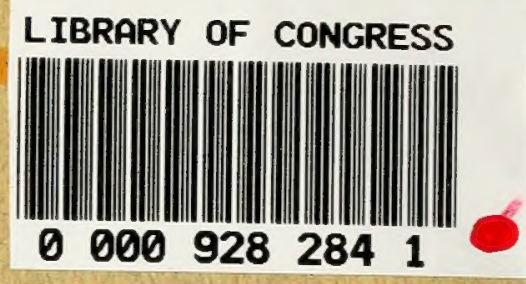

